\title{
Análise da pluridimensionalidade da sustentabilidade da cadeia produtiva de componentes construtivos \\ de madeira de plantios florestais
}

\author{
Andrea Naguissa Yuba
}

Orientadora: Profa. Dra. Akemi Ino 
Andrea Naguissa Yuba

Análise da pluridimensionalidade da sustentabilidade da Gadeia produtiva de componentes eonstrutivos de madeira de plantios florestais

Tese apresentada à Eseola de Engenharia de São Carlos da Universidade de São Paulo como parte dos requisitos para a obtenção do Título de Doutor em Ciêneias da Engenharia Ambiental.

Orientadora: Profa. Dra. Akemi Ino

São Carlos

2005 


\section{FOLHA DE JULGAMENTO}

Candidata: Arquiteta ANDRÉA NAGUISSA YUBA

Tese defendida e julgada em 12-01-2005 perante a Comissão Julgadora:

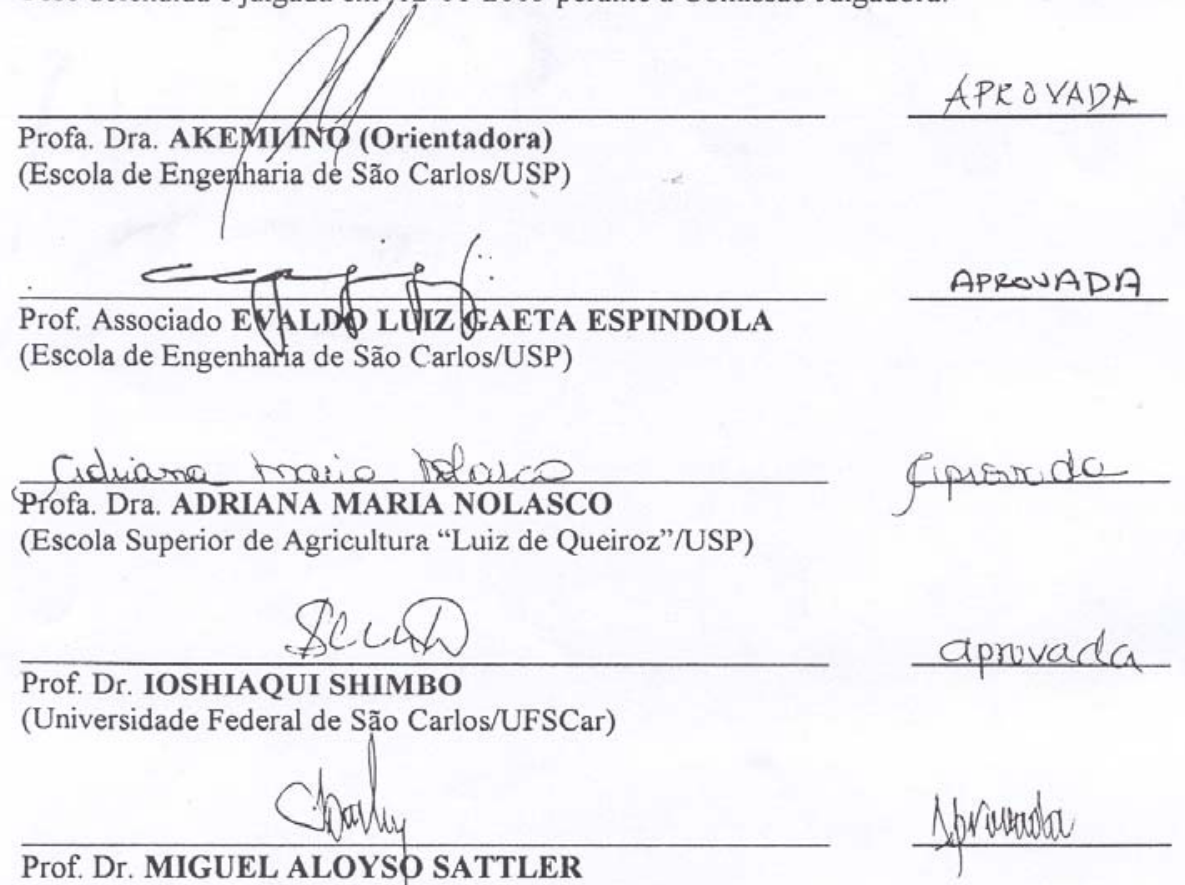

(Universidade Federal do Rio Grande do Sul/UFRGS)

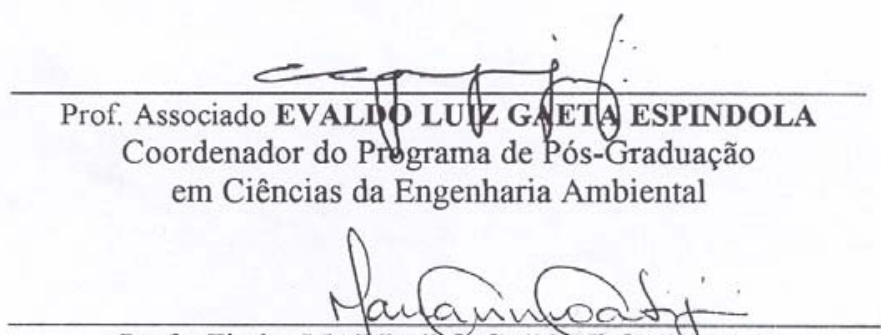

Profa. Titular MARIA DO CARMO CALIJURI

Presidente da Comissão de Pós-Graduação 


\section{Ağradę̧o}

A Akemi que, mais do que orientadora, sempre foi minha amiga.

Ao Shimbo, por toda a confiança depositada em mim.

Aos amigos do HABIS, especialmente Maris, Marininha, Lucia, Fernando, Tati, Josi e Paulo; do CRHEA - Adriana, Carmen, Felipe e Rosane, pelo carinho e apoio.

Ao Obede, pelas contribuições nas traduções.

À minha família, por todas as atitudes, palavras e gestos simples.

E, finalmente, a CAPES e FAPESP pelo provimento da bolsa, que permitiu o desenvolvimento e a integridade deste trabalho. 
"Só esperamos o que não depende de nós; só queremos o que depende de nós. É por isso que a esperança só é uma virtude para os crentes, ao passo que a coragem o épara qualquer homem."

André Comte-Sponville 


\section{RESUMO}

YUBA, A. N. (2005) Análise da pluridimensionalidade da sustentabilidade da cadeia produtiva de componentes construtivos de madeira de plantios florestais. Tese (Doutorado) - Escola de Engenharia de São Carlos, Universidade de São Paulo, São Carlos, 2005.

A cadeia produtiva da habitação em madeira de plantios florestais apresenta características que podem contribuir para a definição de um contexto mais sustentável, mas tal análise depende de uma abordagem que supera a preponderância das questões ambientais, passando a incluir as questões de cunho social, econômico, político e cultural, de forma mais integrada. A proposta de lidar com a totalidade da cadeia produtiva representa a oportunidade de abranger níveis bastante complexos das interações entre as dimensões da sustentabilidade e de relações das mais significativas às mais tênues entre as diversas questões, no universo das múltiplas dimensões de análise a serem consideradas. Diante disso, o objetivo geral desta pesquisa é explorar e sistematizar a complexidade dinâmica das questões de sustentabilidade dessa cadeia produtiva visando à compreensão do processo de ganhos e de perdas de sustentabilidade. Num contexto de conceitos em formação, buscouse a definição e delimitações do objeto analisado, efetuando-se a decomposição e caracterização da cadeia produtiva da habitação em madeira de plantios florestais. Isso possibilitou verificar a ênfase das questões de caráter tecnológico, compartimentadas nos processos de produção, e a falta de uma visão de ciclo, própria da sustentabilidade. Então, buscando estabelecer a relação entre a sustentabilidade e a cadeia produtiva, os princípios e estratégias da construção sustentável foram analisados e relacionados com cada um dos processos que compõem a cadeia produtiva. Com isso, percebeu-se que apesar de haverem princípios de outras dimensões arrolados pelos diferentes referenciais teóricos, a nítida diferença do grau de detalhamento das questões ambientais em relação às outras e também 
entre os processos "iniciais" (exploração de recursos e fabricação) e "finais" da produção (uso e desmontagem).

Uma investigação de métodos de avaliação de sustentabilidade mostrou que a pluridimensionalidade da sustentabilidade e sua inerente complexidade têm sido parcialmente abordadas e operacionalizadas, em detrimento da simplificação, oferecendo uma visão estática, prejudicando o conhecimento do processo de ganhos e de perdas de sustentabilidade. A grande lacuna identificada é a falta de uma abordagem transparente da dinâmica do sistema. Nesse ponto, a visão de elos proporcionada pela noção de cadeia produtiva se mostrou particularmente adequada para o tratamento das questões de sustentabilidade. Assim, na derivação para a cadeia produtiva, são mostradas as relações entre os processos nas diferentes dimensões. Com isso, obtêm-se as interações da rede de questões da cadeia, a percepção de como cada questão repercute nas outras questões, os ganhos e perdas de sustentabilidade em uma dimensão, os ganhos e perdas de sustentabilidade entre as dimensões e o quão interfere cada ação na busca da sustentabilidade, permitindo compreender as melhores e piores associações, embora limitado pelas regionalizações. A diversidade de variáveis a serem consideradas na análise de sustentabilidade dessa cadeia produtiva mostra que mesmo que os elos entre processos possam ser reproduzidos em outros contextos, a sua análise é estritamente relacionada ao lugar e num determinado tempo.

Palavras-chave: sustentabilidade, pluridimensionalidade, cadeia produtiva, habitação, madeira, plantios florestas. 


\section{ABSTRACT}

YUBA, A. N. (2005) Pluridimensional sustainability analysis of wooden building products production chain. $\mathrm{PhD}$ thesis - Escola de Engenharia de São Carlos, Universidade de São Paulo, São Carlos, 2005.

The timber housing production chain from managed forests has characteristics that can contribute to determine a more sustainable context, but it depends on an approach that overcomes the preponderance of environmental issues, including the social, economic, politics and cultural ones, in an integrated way. To deal with the whole production chain is an opportunity to include very complex levels of interactions among sustainability dimensions and different types of relationships (light and strong ones), in the multiplicity of analysis dimensions that can be studied. In this way, the main purpose of this study is to explore and systematize the sustainability issues dynamics complexity of this production chain aiming to understand the process of gains and losses of sustainability. The study reaches the definition and the limits of the context, by disentangling and characterizing this production chain. It showed the technical emphasis of many studies, which are closely separated in the processes, and the absence of a life cycle perspective, inherent to sustainability. So, aiming to establish the relationship between sustainability and the production chain, the principles and strategies of sustainable construction were analyzed and linked to each of the processes of the production chain. It allowed seeing that there are many other dimensions principles, but they are far less detailed than the environmental issues. The same difference can be found between initial processes (use of resources and production) and ending ones (use and disassembling). The analysis of the sustainability evaluation methods showed that sustainability pluridimensionality and its complexity is being partially approached and operationalized to offer a simplified and static vision, damaging the production of knowledge about sustainability gains and losses. The bigger lack is a transparent approach of the system dynamics. So, the links idea of production 
chain concept is particularly suitable to deal with sustainability issues. Deriving them to the production chain, it is showed the interrelationships of the processes in the various dimensions. It was possible to understand the interactions net of the chain issues, how each issue affects others, the sustainability gains and losses in one dimension and among dimensions and how each action can affect the way to sustainability. It allows understanding the better and the worst links, although it is determined by the spatial scale. The items diversity to be considered in sustainability analysis of this production chain shows that even though the links can be applied in different contexts, its analysis is strictly related to one specific area and time.

Keywords: sustainability, pluridimensionality, production chain, housing, wood, timber, managed forest. 


\section{LISTA DE FIGURAS}

Figura 1. Indicadores sociais do Estado de São Paulo

Figura 2. Concentração de florestas plantadas Pólo de Itapeva/Capão Bonito/Buri - Reg Sudoeste

São Paulo 19

Figura 3. Esquema do padrão degenerativo

Figura 4. Esquema de padrão regenerativo 28

Figura 5. Fases básicas do funcionamento do ecossistema regenerativo. .29

Figura 6. Estrutura básica da cadeia produtiva da construção. 67

Figura 7. Processos, produtos e resíduos da cadeia produtiva da habitação em madeira de plantios florestais. .75

Figura 8. Detentores das áreas de reflorestamento do Estado de São Paulo.. 87

Figura 9. Detentores das áreas de reflorestamento da Região Administrativa de Sorocaba. 88

Figura 10. Áreas de plantios acordo com classes de superfície nas respectivas regiões administrativas - eucalipto - detentores não identificados

Figura 11. Área plantada dos dez municípios com quantidades mais expressivas no Pólo de Reflorestamento de Itapeva/ Capão Bonito/ Buri 92

Figura 12. Evolução do reflorestamento (eucalipto, pinus e outros) no Estado de São Paulo, por região administrativa, nos períodos de 1961-62, 1971-73, 1991-92 e 1999-2000.

Figura 13. Evolução dos plantios florestais nas sub-regiões consideradas da Região Administrativa de Sorocaba nos períodos de 1971-73, 1978, 1991-92, 1999-2000 94

Figura 14. Preços médios de toras para serraria em pé no Estado de São Paulo 95

Figura 15. Preços da celulose (FOB) e custo da madeira (CIF, em US $\$ / \mathrm{m}^{\text {st }}$ sem casca) para a produção de 1 tonelada de celulose 98

Figura 16. Exemplificação do modelo de simulação de corte efetuado em AutoCad 2000. 104

Figura 17. Pré-fabricação de componente painel parede de madeira e gesso acartonado. 123

Figura 18. Preparação para transporte de componentes pré-fabricados de habitação em madeira. 124 
Figura 19. Problemas de durabilidade identificados nas habitações de madeira em Itararé..... 127

Figura 20. O paradigma da informação/ ação/ conseqüência do system dynamics. 134

Figura 21. Estrutura da abordagem do system dynamics.

Figura 22. O processo de um system dynamics. 135

Figura 23. Interações ambiente - economia.

Figura 24. Definição PICABUE de desenvolvimento sustentável 147

Figura 25. Padrões em desenvolvimento e em planejamento na área da construção sustentável da ISO. 159

Figura 26. Questões e dimensões trabalhadas pelo Ecopoints - em branco. 160

Figura 27. Exemplo de relatório SBAT... 167

Figura 28. A estrutura do Bequest. 169

Figura 29. Esquema de análise Bequest Toolkit. 169

Figura 30. Características gerais das habitações precárias em Itapeva, Itararé e Itaberá..... 180

Figura 31. Condições inadequadas típicas de serrarias de pequeno porte. 181

Figura 32. Estudos de sistemas construtivos utilizando madeira de plantios florestais da região ... 181

Figura 33. Mapa cognitivo do Grupo Gestor em Itararé - Fase I 183

Figura 34. Mapa cognitivo para assentamentos rurais - Fase I. 184

Figura 35. Mapa cognitivo do Projeto de Políticas Públicas - Fase II 186

Figura 36. Elos entre processos na cadeia produtiva da habitação em madeira de plantios florestais. 188 


\section{LISTA DE QUADROS}

Quadro 1. Princípios e estratégias gerais de sustentabilidade ...................................................................... 33

Quadro 2. Síntese de características básicas da sustentabilidade............................................................... 34

Quadro 3. Princípios ambientais da construção sustentável........................................................................ 38

Quadro 4. Princípios sociais da construção sustentável.............................................................................. 40

Quadro 5. Princípios econômicos da construção sustentável. .................................................................. 42

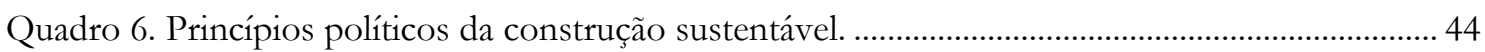

Quadro 7. Princípios culturais da construção sustentável....................................................................... 45

Quadro 8. Princípios da construção sustentável para os organismos governamentais........................ 48

Quadro 9. Princípios da construção sustentável para o processo de exploração de recursos............. 51

Quadro 10. Princípios da construção sustentável para o processo de fabricação.................................. 53

Quadro 11. Princípios da construção sustentável para o processo de projeto ......................................... 56

Quadro 12. Princípios da construção sustentável para o processo de construção. …………………..... 61

Quadro 13. Princípios da construção sustentável para a fase de uso.................................................... 62

Quadro 14. Princípios da construção sustentável para o processo de desconstrução........................... 63

Quadro 15. Comércio internacional - principais produtos e participação do Brasil............................. 71

Quadro 16. Exportações brasileiras de produtos florestais -2002 ......................................................... 71

Quadro 17. Características dos sistemas de certificação florestal, operantes no Brasil........................ 83

Quadro 18. Índice de responsabilidade social do Estado de São Paulo, Região administrativa de

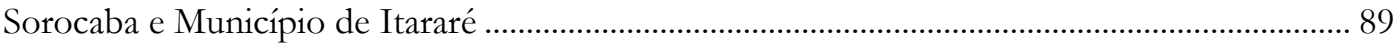

Quadro 19. Resíduos da cadeia produtiva da madeira serrada - tipos e destinação.............................. 102

Quadro 20. Sub-operações e equipamentos de usinagem de madeira serrada. .................................... 109 
Quadro 21. Características dos produtos de pequenas e médias serrarias da Reg. Sudoeste do Est. de SP.

Quadro 22. Comparação do impacto ambiental de produtos químicos utilizados em tratamentos preservativos.

Quadro 23. Implicações para a indústria de produtos de madeira. 122

Quadro 24. Análises de sistemas de ciclo de vida. 137

Quadro 25. Tipos de indicadores da estrutura EEA. 162

Quadro 26. Áreas de avaliação do SBAT.. 166

Quadro 27. Diferenças entre a visão tradicional e a inovadora de desempenho ambiental. 173

Quadro 28. Objetivos comuns dos métodos de avaliação ambiental 175

Quadro 29. Proposição para os objetivos das avaliações de sustentabilidade 176 


\section{LISTA DE TABELAS}

Tabela 1. Detentores das áreas de reflorestamento no Estado de São Paulo..................................... 86

Tabela 2. Detentores das áreas de plantios florestais na Região Administrativa de Sorocaba........... 87

Tabela 3. Relação dos dez municípios com índices mais expressivos de plantios florestais do Pólo de Reflorestamento de Itapeva/ Capão Bonito/ Buri............................................................... 92

Tabela 4. Valores de consumo de energia na fase de transformação primária da madeira nas serrarias

Tabela 5. Estrutura dos custos de desdobro e secagem de pinus. 105

Tabela 6. Critérios para avaliação da contaminação de água canadense. 114

Tabela 7. Concentração de arsênico no solo no entorno de postes de madeira tratada. 115

Tabela 8. Matriz de impacto fuzzy. 141

Tabela 9. Avaliações fuz:yy de impactos das diferentes meios de ação alternativos sobre os diferentes grupos de interesse. 142

Tabela 10. Cálculo da pegada ecológica dos EUA 150

Tabela 11. Demanda habitacional urbana - Região Sudoeste de São Paulo 179

Tabela 12. Demanda habitacional rural - Ass. Rural Faz. Pirituba - Agrovilas 1,2,3,4,5 e 6. 179

Tabela 13. Quantidade de serrarias na região em 1997 180 


\section{SUMÁRIO}

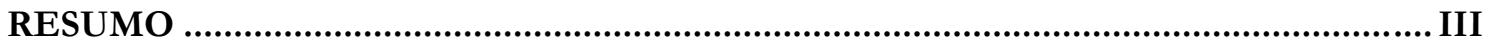

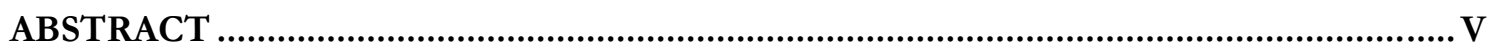

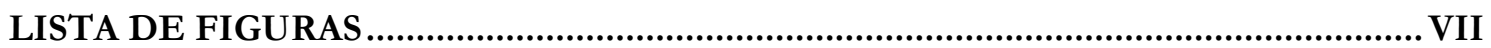

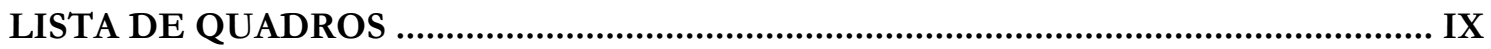

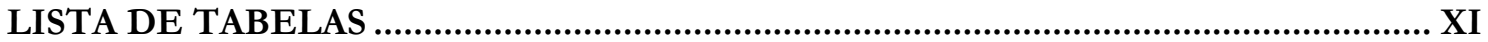

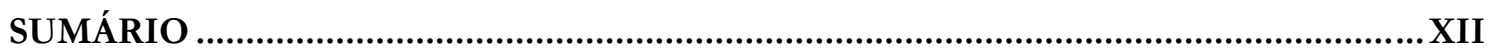

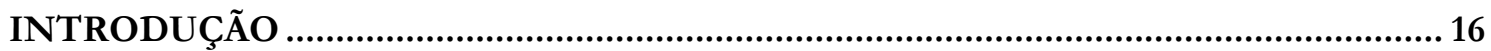

\section{CAPÍTULO 1. SISTEMATIZAÇÃO DAS CARACTERÍSTICAS DA}

SUSTENTABILIDADE APLICADAS À CONSTRUÇÃO CIVIL ....................................25

1.1. Evolução da compreensão sobre a construção civil .......................................................... 25

1.2. Evolução da compreensão sobre a construção sustentável nos países em

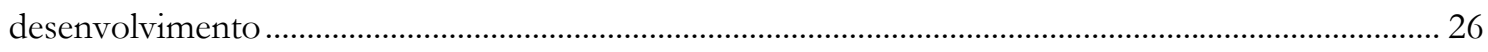

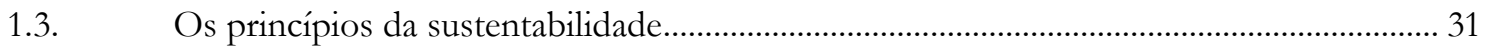

1.3.1. Princípios da sustentabilidade para a totalidade do setor da construção civil.................... 36

1.3.2. Princípios, desafios e estratégias para os processos da cadeia produtiva dos materiais de construção 46

3.1.1.1. Processo de exploração dos recursos naturais ........................................................................ 48

3.1.1.2. Processo de fabricação de materiais de construção ................................................................. 51

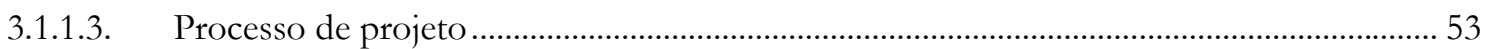

3.1.1.4. Processo de construção ……………………………………………………………..... 56

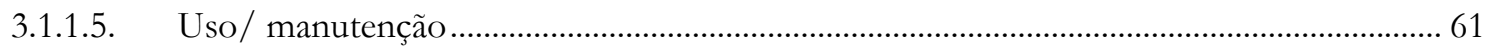

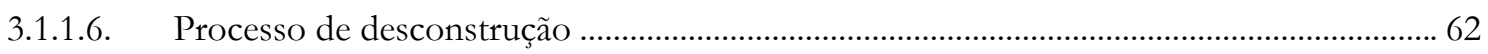




\section{CAPÍTULO 2. A CADEIA PRODUTIVA DA HABITAÇÃO EM MADEIRA DE}

PLANTIOS FLORESTAIS.

3.1. As delimitações dadas pela noção de cadeia produtiva

3.2. Decomposição da cadeia produtiva da habitação em madeira de plantios florestais ....... 73

3.3. Caracterização dos processos da cadeia produtiva da habitação em madeira de plantios florestais 76

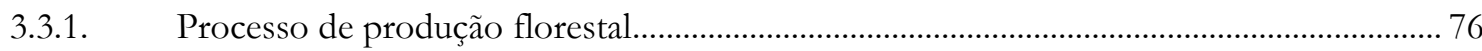

3.3.1.1. Os impactos ambientais (no solo, recursos hídricos, fauna, flora e clima) causados pelas espécies e pela atividade de silvicultura intensiva .78

3.3.1.2. A geração de oportunidades de emprego local e regional versus a crescente concentração fundiária 85

3.3.1.3. Possíveis causas para a redução da oferta de madeira de plantios florestais no mercado89

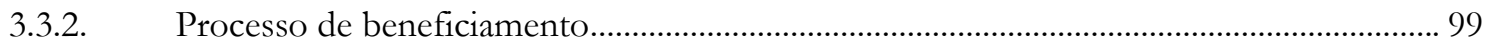

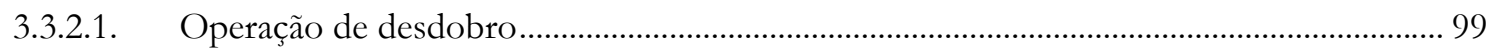

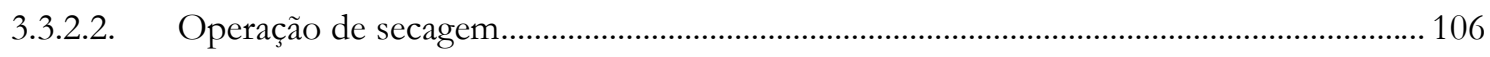

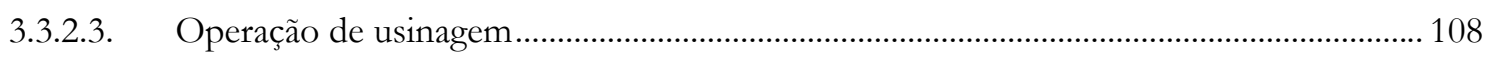

3.3.2.4. Operação de tratamento preservativo …………………………………………………….... 111

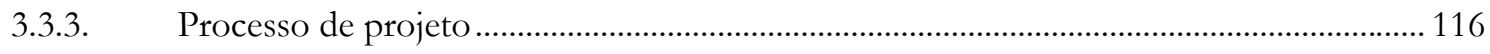

3.3.4. Processo de construção (pré-fabricação e montagem) …………………………………..... 122

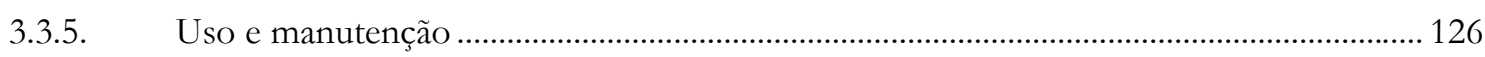

3.3.6. Processo de desmontagem, reaproveitamento, reuso e reciclagem................................... 128

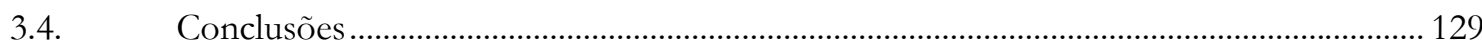

CAPÍTULO 3. POSTURAS FRENTE À INDISSOCIABILIDADE DAS DIMENSÕES

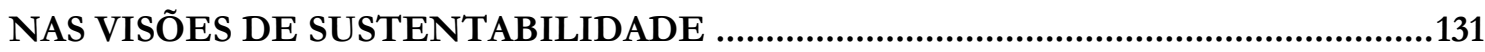

3.1. Contribuições conceituais e metodológicas de abordagens mais ampliadas ..................... 132

3.2. Ferramentas para promoção da interação entre dimensões da sustentabilidade ............. 140

3.3. Status da pluridimensionalidade dos métodos de avaliação de sustentabilidade.............. 145

3.3.1. Método de avaliação unidimensional da sustentabilidade da construção civil: dimensão ambiental 147

3.4.1.1. Método das preferências ambientais, Holanda 
3.4.1.2. $\quad \mathrm{EBN}, \mathrm{EUA}$

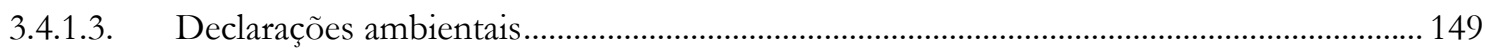

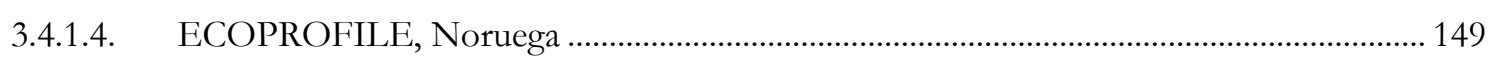

3.4.1.5. Miljöstatus ou Environmental Status, Suécia ....................................................................... 149

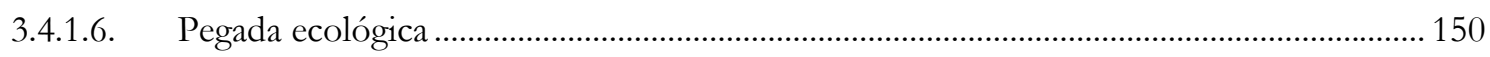

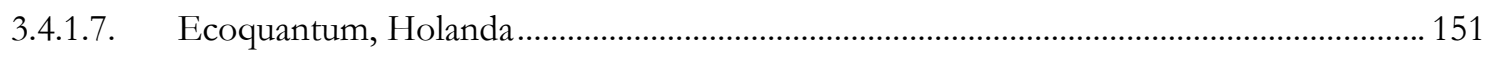

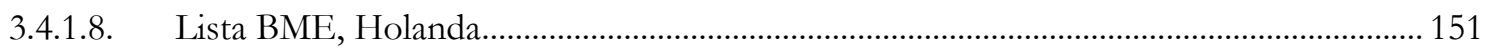

3.3.2. Método de avaliação unidimensional da sustentabilidade da construção civil: dimensão social 152

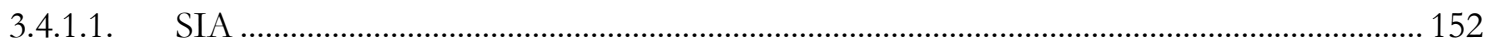

3.3.3. Método de avaliação bidimensional da sustentabilidade da construção civil: dimensões ambiental e econômica.

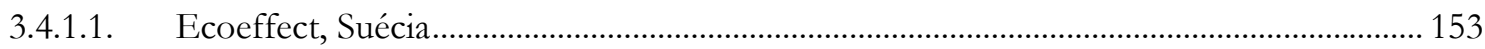

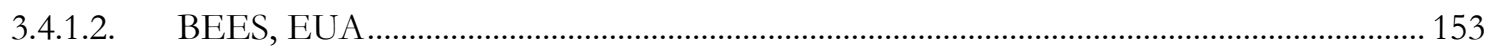

3.3.4. Método de avaliação bidimensional da sustentabilidade da construção civil: dimensões ambiental e social.

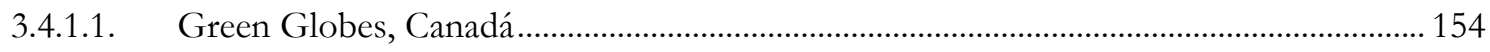

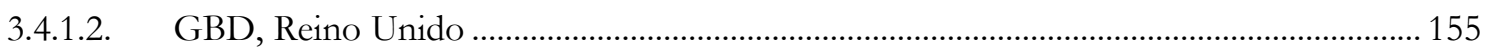

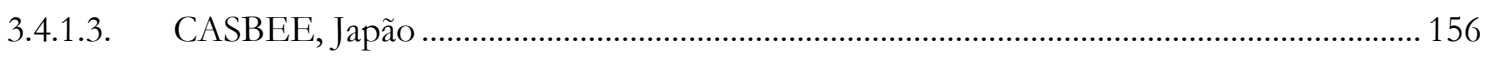

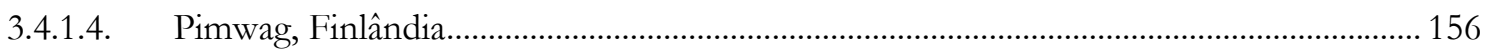

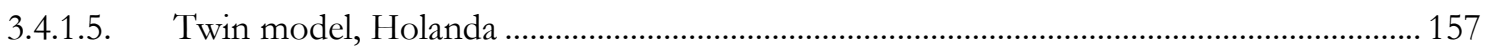

3.3.5. Método de avaliação bidimensional da sustentabilidade da construção civil: dimensões

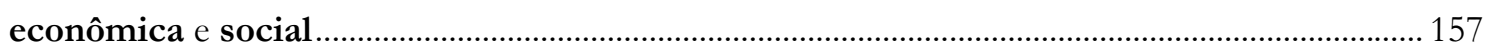

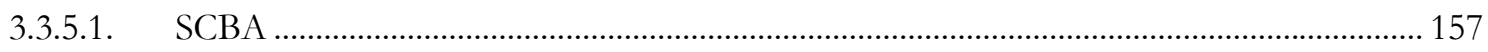

3.3.6. Método de avaliação tridimensional da sustentabilidade da construção civil: dimensões

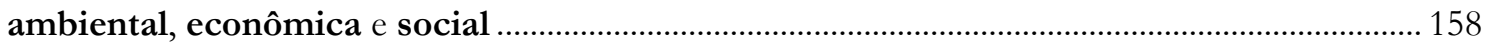

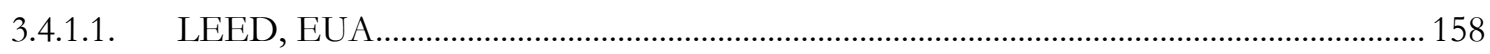

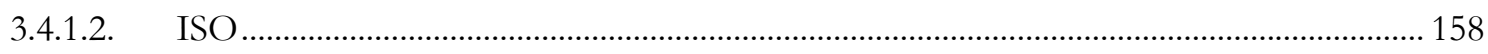

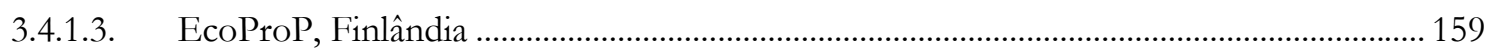




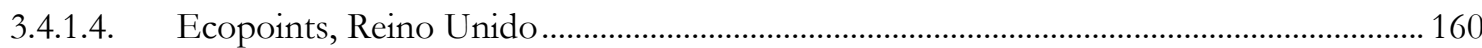

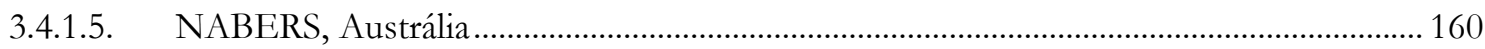

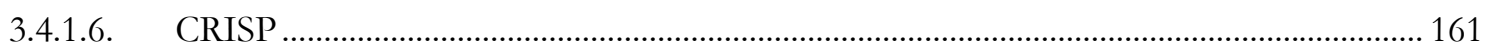

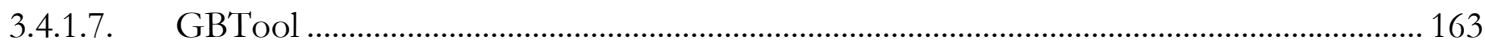

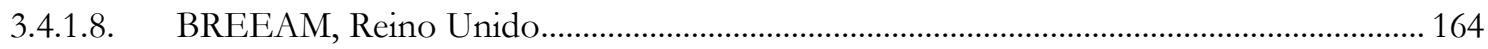

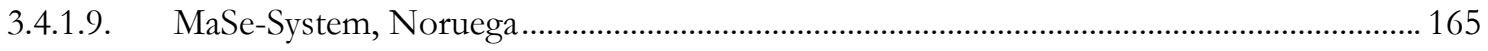

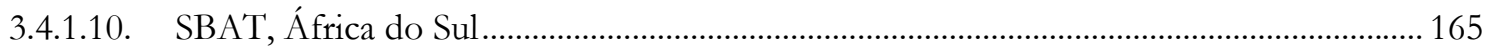

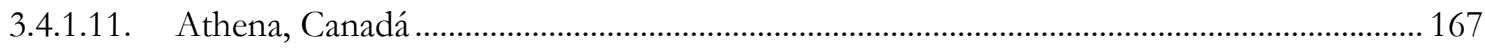

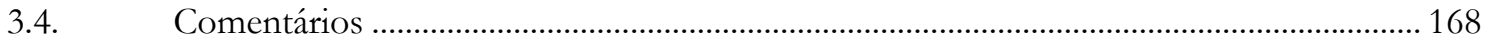

CAPÍTULO 4. A DERIVAÇÃO DAS CARACTERÍSTICAS DA SUSTENTABILIDADE PARA A ANÁLISE DA CADEIA PRODUTIVA DA HABITAÇÃO EM MADEIRA DE

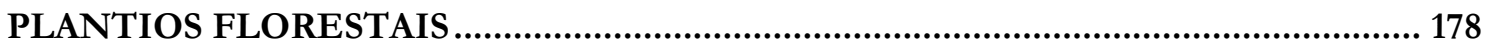

4.1. Caracterização do objeto empírico - o contexto do Projeto de Políticas Públicas......... 178

4.1.1. Histórico do projeto ................................................................................................. 179

4.1.2. Estratégias adotadas para a sustentabilidade ........................................................................ 182

4.2. Uma visão dos elos entre os processos da cadeia produtiva da habitação em madeira de

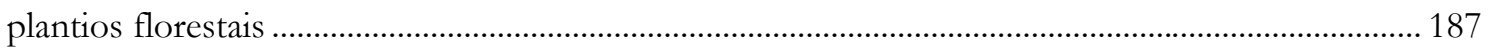

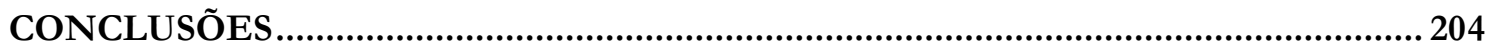

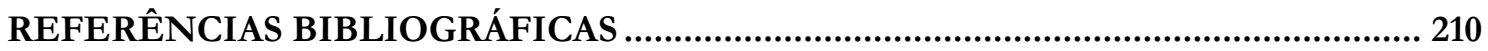




\section{INTRODUĞ̣̂̃O}

A discussão sobre os materiais de construção pode contribuir mais do que o faz atualmente para a sustentabilidade. Ser ou não ambientalmente correto não é o único aspecto a ser analisado, já que a sustentabilidade não é determinada somente pelo tipo de produto.

Se o foco sobre as questões ambientais for ampliado para uma discussão pluridimensional, muitas outras questões pertinentes poderão também ser mais bem trabalhadas. Isso agrega o desafio de complexidade além das que são atualmente enfrentadas pelos sistemas de avaliação de sustentabilidade existentes.

Em nome da exeqüibilidade, muito dessa complexidade tem sido desconsiderada. Não se trata de hierarquizar qual a dimensão da sustentabilidade mais importante a ser trabalhada, como propõem alguns métodos, mas de investigar o conjunto das questões e a relação entre as várias dimensões, para compor bases mais sólidas para a tomada de decisões.

Além disso, em muitos, a base do conceito é equivocada, sendo motivada por um cunho capitalista, em que o desenvolvimento se dá prioritariamente através do crescimento.

No rol de materiais em discussão, a madeira de plantios florestais é um dos que têm potencial para o atendimento aos princípios da sustentabilidade. Freqüentemente se questiona o "grau de sustentabilidade" da madeira de plantios florestais e se há condições para que esse material tenha um futuro mais sustentável que o atual.

Observando somente o aspecto ambiental, os produtos à base de madeira são mais atrativos que muitos outros materiais. Numa pesquisa feita pelo Canadian Wood Council (1996) verificou-se que entre os especificadores de materiais de construção, a maioria considerou a madeira como o material ambientalmente mais amigável. Essa escolha foi pautada pela renovabilidade do material, o baixo consumo de energia na sua produção e os baixos níveis de emissão de poluição durante o seu processamento. Entretanto, apesar das vantagens ambientais, o usuário ainda tem preocupações sobre a madeira. 
Mas os estudos sobre esse material ainda são caracteristicamente isolados, não havendo uma visão de cadeia de produção que as relacione e nem um encadeamento proposital para estudos de sustentabilidade.

As pesquisas de desenvolvimento tecnológico são as mais comuns sobre a madeira caracterização, experimentos de sistemas construtivos de pequenos, médios e grandes portes, novos materiais e normas, presentes nos EBRAMEM ${ }^{1}$.

Muitas das pesquisas apontam em seu contexto a utilização da madeira de plantios florestais como uma alternativa mais sustentável. Entretanto, o exame da abrangência desses estudos mostra a incidência considerável de pesquisas realizadas apenas em laboratório, onde há possibilidade de limitar, e por vezes controlar, as variáveis de análise.

Poucos dos estudos apresentados propõem-se à uma efetiva transferência de tecnologia ou a uma análise da realidade visando a aplicação direta dos resultados obtidos.

Outros apresentam resultados que isoladamente não são possíveis de serem aplicados na realidade, dado o estreitamento do contexto para a realização da pesquisa, fazendo com que se aumente a dificuldade de aplicação pelos agentes da cadeia produtiva, principalmente quando se trata das serrarias e marcenarias, sobre as quais há outras variáveis importantes que devem ser consideradas.

A aplicação na realidade se torna mais complexa quando se considera que as pesquisas têm uma visão compartimentada da realidade do setor e que não há colaborações entre pesquisas ou diretrizes para o desenvolvimento de pesquisas sobre a cadeia produtiva. Grande parte das pesquisas que tratam de sustentabilidade referem-se basicamente a duas dimensões: a ambiental e a econômica, sendo que a segunda aborda apenas o aspecto de custo.

As pesquisas mais amplas, que possam conjugar as pesquisas compartimentadas, a visão de cadeia produtiva e não apenas do processo produtivo estão entre as lacunas de pesquisa identificadas.

Isso significa considerar que variáveis em cada estudo compartimentado interferem nas fases anteriores e posteriores da cadeia produtiva e que portanto causas e conseqüências devem fazer parte da análise e serem consideradas para a busca de um contexto o mais sustentável possível em suas várias dimensões - ambiental, social, econômicas, política, 
cultural, tecnológica entre outras. Inserida na discussão sobre a produção de habitação, o leque de questões sobre a madeira é ampliado.

Antes da proposição de mais um método de avaliação de sustentabilidade, foi verificada a necessidade de pesquisar a conexão entre fatos que podem ser de dimensões diferentes para permitir a compreensão do processo formador e mantenedor do cenário. Isso parte do pressuposto de que a tomada de decisões em sustentabilidade não é maniqueísta, não existindo um "melhor" e um "pior" absolutos. Existem sim as piores e melhores associações que apresentam ganhos e perdas nas escolhas. Da mesma forma não se pode assumir uma dimensão mais importante ou menos importante, ou mais ou menos urgente, já que as dimensões são indissociáveis. Uma grande decisão é composta por várias decisões menores, algumas "pró-ambiental" e "contra-econômica", outras "pró-social" e "contraambiental", por exemplo.

A oportunidade de realização da pesquisa se deve ao vínculo com o Projeto de Políticas Públicas "Habitação social em madeira de reflorestamento como alternativa econômica para usos múltiplos da floresta", apoiado pela FAPESP².

A escolha da Região Sudoeste do Estado de São Paulo como objeto empírico se deveu à presença significativa de povoamentos florestais em contraposição com os seus baixos indicadores sociais (FOLHA DE SÃO PAULO, 2003). Várias metas e estratégias foram traçadas, com o intuito de desenvolver diretrizes para produção de habitação social, reposição florestal e geração de emprego e renda de forma sustentável em torno da cadeia produtiva da madeira de plantios florestais na região.

As atividades desse projeto foram iniciadas no Município de Itararé, em 1998 e atualmente estão concentradas no Município de Itapeva, especificamente no Assentamento Rural Fazenda Pirituba.

\footnotetext{
2 Programa de Pesquisa em Políticas Públicas da FAPESP, processo no 98/14124-1. Fase I - outubro de 1999 a julho de 2000 . Fase II julho de 2001 a julho de 2004.
} 


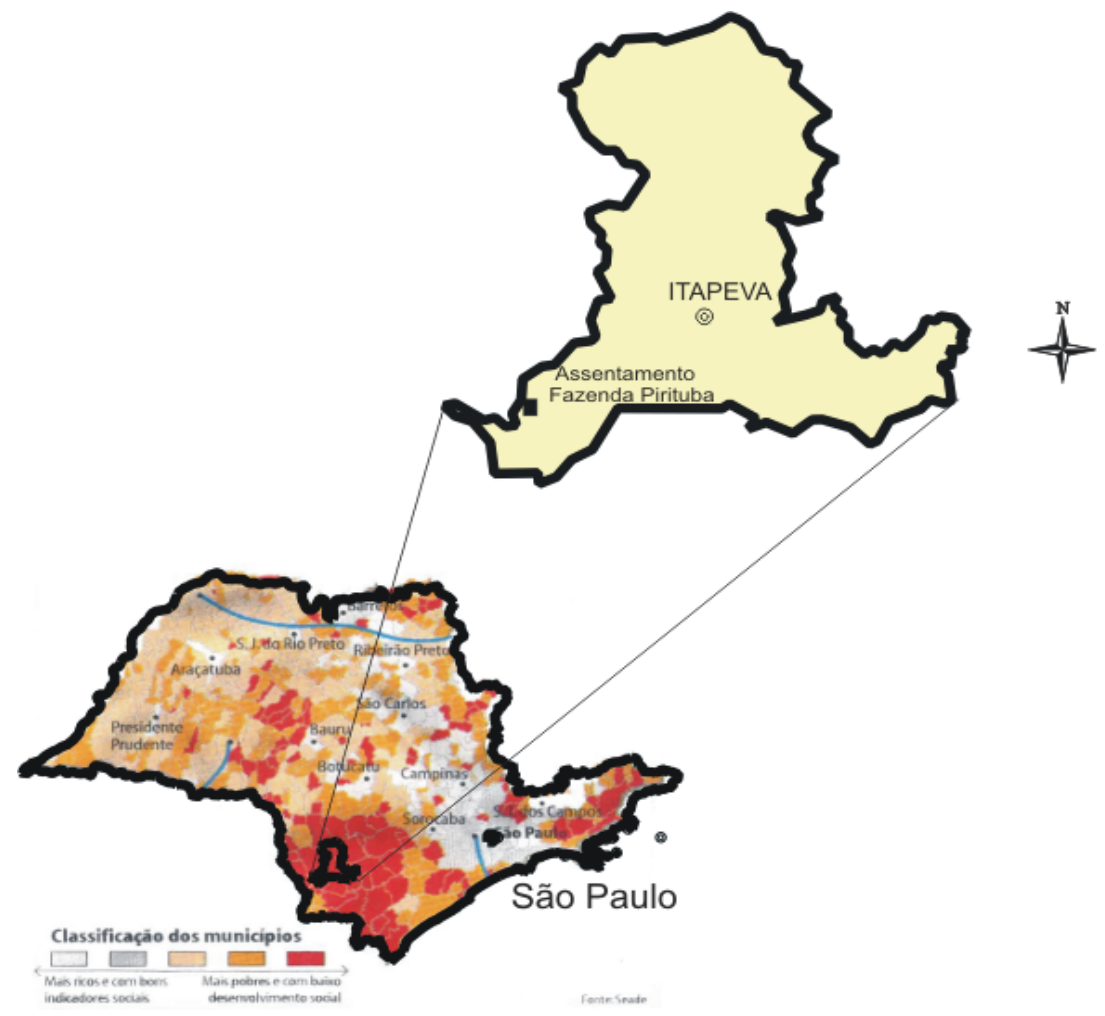

Figura 1. Indicadores sociais do Estado de São Paulo fonte: Folha de São Paulo (2003)

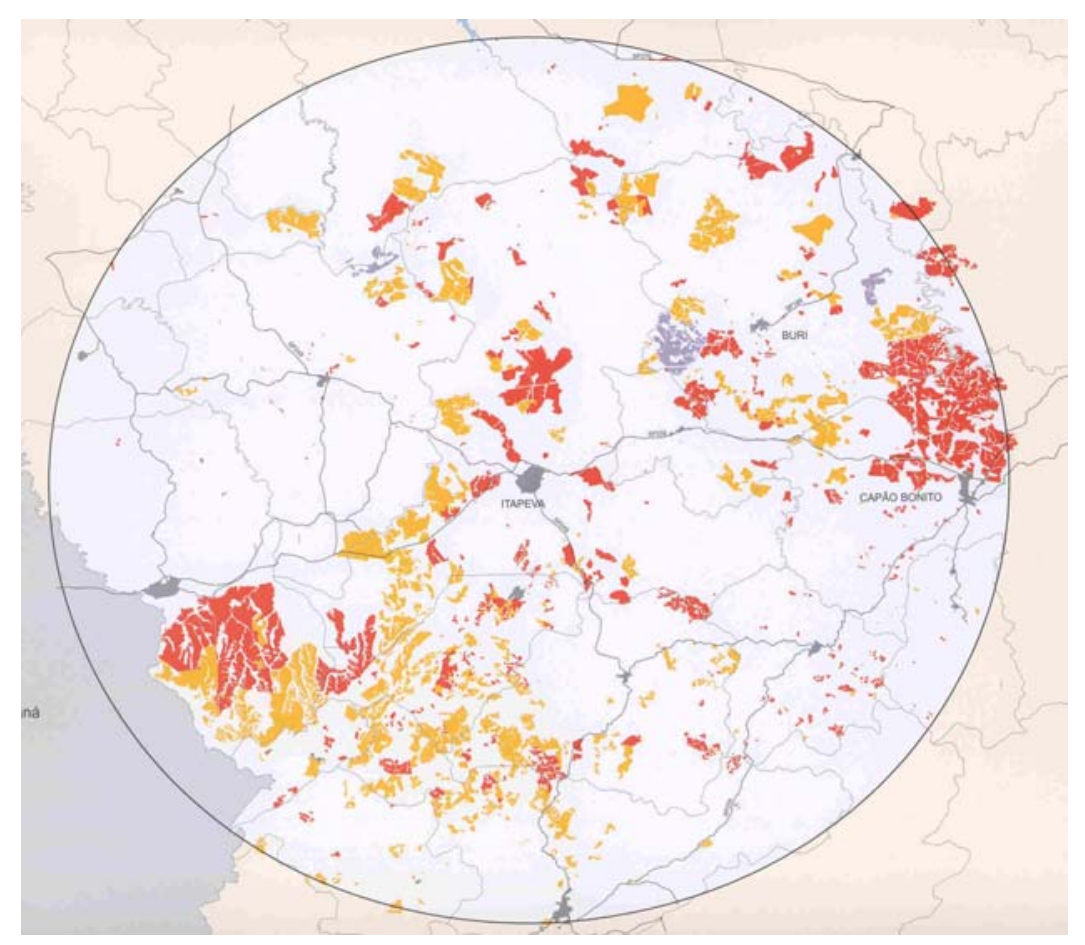

Figura 2. Concentração de florestas plantadas Pólo de Itapeva/Capão Bonito/Buri - Reg Sudoeste São Paulo. Fonte: Kronka (2002) 
Corroborando a escolha da região para a execução do Projeto, um diagnóstico realizado em parceria entre o SEBRAE $/ \mathrm{SP}^{3}$ e $\mathrm{UNICAMP}^{4}$ constatou entre as potencialidades para o desenvolvimento sustentável do Município de Itararé, o desenvolvimento de um pólo madeireiro na região (SEBRAE/SP, 2000).

Diante dessa contradição, o primeiro questionamento que se realiza é sobre a real inserção do debate complexo da sustentabilidade na discussão no âmbito da construção civil e em escalas menores - nas várias cadeias produtivas envolvidas.

A segunda questão, de cunho mais metodológico, se refere à maneira de executar o debate de tal complexidade, sob uma visão sistêmica e pluridimensional.

A primeira hipótese é de que a "visão" sustentável deve estar munida da análise do maior número possível de interações entre as variáveis de um dado contexto. Por isso, para compreender a sustentabilidade seria necessário entender como a realidade opera.

Por sua vez, a compreensão da dinâmica requer uma análise abordando diferentes dimensões, havendo uma escala mínima para lidar com a diversidade de questões, maior do que a normalmente utilizada pelas pesquisas tradicionais sobre a madeira de plantios florestais. Essa escala seria a da cadeia produtiva.

A segunda hipótese baseia-se na idéia de que a sustentabilidade está sendo compreendida erradamente desde a sua base e tem sido abordado de forma parcial, com pequenas nuances na tentativa de congregar uma visão de sustentabilidade.

Diante disso, o objetivo desta pesquisa é sistematizar a complexidade dinâmica das questões de sustentabilidade da cadeia produtiva da habitação em madeira de plantios florestais visando à compreensão do processo de ganhos e de perdas de sustentabilidade.

Para tanto, os objetivos intermediários são:

- Avaliar a inserção da complexidade da sustentabilidade na construção civil;

- Estabelecer uma compreensão sobre as questões de sustentabilidade nas fases do ciclo de vida da habitação em madeira de plantios florestais;

- Analisar a amplitude da interação entre processos e entre dimensões na cadeia produtiva da habitação em madeira de plantios florestais. 
Outra hipótese além das citadas é de que a operacionalização do conceito de sustentabilidade pode contribuir para o almejado desenvolvimento da cadeia produtiva da madeira de plantios florestais, incluindo a vertente da produção de habitação.

Tratando-se de uma pesquisa de caráter propositadamente abrangente, envolvendo questões de variados campos do conhecimento, a proposta é a de uma análise exploratória global. O método então compõe se de:

1. pesquisa bibliográfica sobre as etapas do processo produtivo de madeira serrada, habitações em madeira, plantios florestais e sobre o conceito de cadeia produtiva para decompor e caracterizar a cadeia produtiva da habitação em madeira de plantios florestais. A necessidade dessa etapa se deveu à insuficiência da visão tradicional das pesquisas existentes para uma abordagem de sustentabilidade. Ainda assim, as questões de sustentabilidade apresentadas são referentes ao processo em si.

2. coleta de dados na Região Sudoeste do Estado de São Paulo, nos municípios de Itararé, Itapeva e Itaberá, além de algumas serrarias de Sengés/PR (município vizinho a Itararé) para a complementação de dados para a caracterização da cadeia produtiva. A coleta de dados foi realizada entre agosto de 2002 e março de 2004, para identificação dos fluxos de materiais, de relações de comércio entre os agentes da cadeia e de informações sobre produtos e preços praticados. Foram observados os processos produtivos das empresas, complementados com entrevista aos dirigentes e trabalhadores, além do registro fotográfico dos produtos e processos visitados, apresentados em Ferreira Jr. (2003). Os processos produtivos de serrarias de variados portes foram analisados, o que possibilitou perceber as diferenças existentes no grau de desenvolvimento tecnológico e o grau de autonomia na produção, principalmente quando relacionadas às empresas que detém áreas de plantios florestais. Outras empresas da cadeia produtiva que também foram visitadas foram as de plantios florestais (pertencentes ou não a serrarias), que mostraram as ligações cada vez mais fortes com o mercado externo, e as marcenarias, com as suas especificidades produtivas e tecnológicas, evidenciando uma clara preocupação com o aumento no custo das matérias-primas e na dificuldade de utilização do pinus e eucalipto produzidos na região.

3. pesquisa bibliográfica sobre a aplicação do conceito de sustentabilidade nos processos dessa cadeia produtiva. O objetivo era obter uma visão pluridimensional da sustentabilidade no entorno da utilização de madeira para a produção de habitações e princípios de sustentabilidade específicos para a madeira. Entretanto, devido a 
preponderância da dimensão ambiental nas pesquisas analisadas e aos poucos dados sobre madeira, procedeu-se com a realização da etapa seguinte.

4. pesquisa bibliográfica sobre o conceito de sustentabilidade aplicado ao setor da construção civil. Esse procedimento buscou recuperar a integridade do conceito e as inter-relações entre as dimensões da sustentabilidade. Foi realizada uma análise dos referenciais teóricos para formar um conjunto de princípios, ações, desafios e estratégias para a sustentabilidade, nas dimensões ambiental, social, econômica, política e cultural, sobre a visão de ciclo de vida (exploração de recursos naturais, fabricação de materiais de construção, projeto, construção, uso e desconstrução), para uma abordagem o mais próxima possível da visão de cadeia produtiva. Percebeu-se nessa busca que pouco do caráter de indissociabilidade entre as dimensões é contemplado, além de muitas lacunas existentes tanto nas pesquisas quanto na operacionalização.

5. pesquisa dos métodos de avaliação de sustentabilidade, que se propõem definir o status de materiais e edificações frente à sustentabilidade. Essa pesquisa buscou identificar a estrutura, objetivos e tipos de resultados, além da forma como lidam com a visão pluridimensional. Foi objeto de investigação também a possível contribuição para uma visão dinâmica da sustentabilidade. Sabido que os métodos têm um enfoque preponderantemente ambiental, a análise de tais métodos foi pautada na identificação das lacunas para uma visão mais abrangente. Observou-se a excessiva simplificação da realidade além da formação de uma visão estática sem possibilidade de compreensão das razões que levaram às decisões. Uma vez que nenhum deles efetua uma análise da dinâmica, foi definido o item seguinte. A visão de múltiplas dimensões ocorre, mas de forma segregada uma da outra e relacionada somente ao processo em si.

6. pesquisa bibliográfica de ferramentas e conceitos afins à sustentabilidade que contribuíssem para uma efetiva visão pluridimensional. Nessa pesquisa foram identificados os conceitos de system dynamics, a teoria de sistemas e ferramentas como a avaliação multi-critérios, que reforçaram a tese de que a hierarquização das questões de sustentabilidade é contrária ao conceito, pelo menos nas avaliações de sustentabilidade.

7. buscando compreender como cada questão de sustentabilidade dentro da cadeia produtiva repercute nas outras questões, elaborou-se uma análise da cadeia produtiva da habitação em madeira de plantios florestais, estabelecendo os elos pluridimensionais mais comuns que formam a dinâmica entre as questões de sustentabilidade, dentro de cada processo e entre processos, em uma dimensão e em múltiplas dimensões para 
explicitar o processo dinâmico de ganhos e perdas de sustentabilidade. Como utiliza dados das etapas anteriores, a composição dos dados para formar a dinâmica é pautada parte em um exame da literatura e parte na análise da realidade de Itararé/ SP, buscando relações entre os elos da cadeia produtiva que não fossem efêmeros, para aumentar a possibilidade de replicação em outros contextos. Os dados da realidade são provenientes das visitas realizadas às serrarias e acompanhamento das reuniões do Projeto de Políticas Públicas, que foram realizadas em Itararé.

Para estruturar esse conjunto de questões, foram elaborados os seguintes capítulos:

O Capítulo 1 busca resgatar a visão original do conceito de sustentabilidade e as questões da aplicação desse conceito ao contexto da construção civil, explorando os seus aspectos que não estão presentes ainda na discussão. Sendo um conceito em formação, que apresenta pontos de vista muitas vezes contraditórios, são apresentados os princípios da literatura para o setor como um todo e para cada um dos processos das cadeias produtivas dos materiais de construção. Os princípios especificamente relacionados à madeira identificados também são apresentados. Assim, possibilitou-se também a realização de uma análise crítica sobre essa evolução, em relação às características originais do conceito.

O Capítulo 2 apresenta a cadeia produtiva da habitação em madeira de plantios florestais, primeiro delimitando-a, de modo a tornar possível a realização da pesquisa e depois decompondo e caracterizando os processos e operações da cadeia produtiva, desde a produção florestal à desmontagem, reaproveitamento, reuso e reciclagem. São caracterizados os processos que compõem a cadeia produtiva, segundo seus agentes, inputs e outputs e descrição das operações de transformação, atentando para a investigação das questões que geralmente são contempladas pelos princípios da sustentabilidade dentro dos processos.

O Capítulo 3 mostra diferentes abordagens conceituais e ferramentas que contribuem para traduzir os princípios do conceito de sustentabilidade e que mostram a importância do trabalho pluridimensional e a visão do contexto como sistemas complexos. Visão essa que ainda está ausente nas pesquisas de experimentação em laboratório e também na maior parte da pesquisa de sustentabilidade, que exploram com enfoque a dimensão ambiental. Apresenta também alguns dos métodos existentes que se propõem de uma ou outra forma a avaliar a sustentabilidade de materiais e edificações. Transparece na comparação com as abordagens conceituais a visão parcial dos métodos. Quando trabalham com mais de uma 
dimensão, não analisam as relações entre questões, ou seja, os fatores determinantes do processo de ganho e de perda de sustentabilidade.

Então, no Capítulo 4 a proposta é fazer tal inclusão da complexidade na cadeia produtiva da habitação em madeira de plantios florestais. Buscando uma forma de organização que mostrasse as inter-relações entre os processos da cadeia produtiva e entre dimensões da sustentabilidade de forma compreensível e facilitada, a cadeia produtiva é apresentada sob o ponto de vista dos elos entre processos, para mostrar a dinâmica dos ganhos e perdas de sustentabilidade e delinear as relações entre as dimensões para a compreensão da rede de questões que determinam a formação de um contexto mais ou menos sustentável.

Analisando o conjunto das investigações realizadas, são apresentadas as considerações finais e perspectivas de continuidade da pesquisa. 


\section{CAPITULO 1}

\section{SISTEMATIZAÇÃO DAS GARACTERISTICAS DA SUSTENTABILIDADE APLICADAS À CONSTRUCG̣ÃO GIVIL}

A visão compartimentada e focalizada em uma dimensão limita uma apropriada exploração da realidade que não contribui para a visão de sustentabilidade. Além disso, a difusão de idéias em formação, com o conseqüente abrandamento do conceito e mau emprego do termo, acabou gerando lacunas nessa discussão.

Em virtude desse cenário, para discutir a sustentabilidade da cadeia produtiva da habitação em madeira de plantios florestais, que está relacionada à discussão dos materiais de construção, considera-se a importância da recuperação das bases do conceito de sustentabilidade e de seus princípios e da própria noção sobre o setor da construção civil, que vem também acompanhando a discussão.

\subsection{Evolução da compreensão sobre a construção civil}

As definições sobre o setor da construção civil são complexas, pelo envolvimento de várias cadeias produtivas diferentes. Diferentes níveis de compreensão são apresentados pela Agenda 21 da Construção Sustentável para países em desenvolvimento (CIB e UNEP ${ }^{5}$ IETC, 2002).

As primeiras formas de visão, como canteiro de obras e como ciclo de produção e que abordam somente os aspectos técnicos do processo, já são consideradas ultrapassadas por não comportar as questões de sustentabilidade. Numa escala maior, variáveis econômicas são introduzidas com a definição: "um setor da economia, que é por sua vez ligada a setores e indústrias de produção de materiais e distribuição afins, assim como setores de 
serviço [...]". Esse nível de abordagem corresponde ao construbusiness latino-americano (CIB e UNEP-IETC, 2002).

A crítica dessa Agenda para as três primeiras definições se deve ao fato de que, apesar de progressivamente incluírem mais questões de relevância para a sustentabilidade, ainda são limitados por lidarem somente com os aspectos "biofísicos" e econômicos.

Então, uma quarta definição é dada, entendendo a construção como "um amplo processo/ mecanismo de concepção de assentamentos humanos". Segundo a Agenda, essa definição, focalizada no provimento de assentamentos, agrega o componente humano e conseqüentemente o atendimento a questões sociais como o tratamento adequado às necessidades básicas, pobreza, ameaças aos valores culturais e desigualdades.

Bakens define o setor a partir dos agentes que o compõe: "todos os profissionais, empresas e organizações (e suas associações representativas) que contribuem para o desenvolvimento, manutenção e demolição/ desconstrução de edificações e outras construções que compõem o ambiente construído" (BAKENS, 2003, p.10).

É analisado por esse autor que para muitos, o setor se restringe à atuação de empreiteiras, prestadores de serviços e "às vezes" a sub-prestadores de serviços, ou seja, aos agentes diretamente relacionados com o usuário final. Essa percepção é comum nas pesquisas feitas em países desenvolvidos. Desse modo, alguns aspectos comuns nem sempre são pertinentes ao contexto brasileiro, como a demasiado enfoque em empresas de habitação pré-fabricada e outros não são desenvolvidos, como a autoconstrução.

\subsection{Evolução da compreensão sobre a construção sustentável nos países em desenvolvimento}

Com as contínuas abordagens, distintas interpretações têm sido dadas para os termos em torno da sustentabilidade. "Construção sustentável" no início, resumia todas as atividades do setor que tivessem alguma relação com o conceito. Recentemente, outros termos têm sido utilizados para distinguir as diversas atuações - "edificações e construções sustentáveis", "edificações e ambiente construído sustentáveis", "indústria da construção sustentável”.

Por um lado, isso representa um esforço de evolução, mas por outro, pode gerar confusões e erros de interpretação. Bakens comenta que "tomadores de decisão, profissionais e pesquisadores [...] freqüentemente parecem falar línguas diferentes, baseados em diferentes 
entendimentos do que a sustentabilidade da construção civil engloba, distintas bagagens culturais e educacionais, assim como distintas responsabilidades e interesses - juntamente com distintas definições de questões, prioridades e possíveis soluções” (BAKENS, 2003, p.11).

A primeira definição mais clara de construção sustentável adotada pelo CIB (1999) é a que foi dada por Kibert, na I Conferência Internacional sobre Construção Sustentável, em 1994, que é imbuído de uma forte carga ambiental: “a criação e gerenciamento responsável de um ambiente construído saudável baseado em princípios ecológicos e de eficiência de recursos", quando ainda era comum compreender a sustentabilidade como um "conceito ambiental defendendo a manutenção e reparo das condições ambientais atuais" e o desenvolvimento sustentável como a defesa da "meta de sustentar o desenvolvimento atual”. Predomina nessa visão o papel crucial dado à tecnologia.

Trabalhando especificamente com a atuação dos projetistas sob esse conceito, Lyle identifica um padrão degenerativo nas relações entre homem e meio ambiente (Figura 3)

[...] os humanos trocaram a ciclagem e reciclagem infinitas de materiais da natureza, processos da alma do sistema de funcionamento da Terra, por um sistema fechado de fluxos de mão única, movimentando os materiais que dão suporte à vida em grandes quantidades da fonte, através do consumo até o descarte (LYLE, 1994).

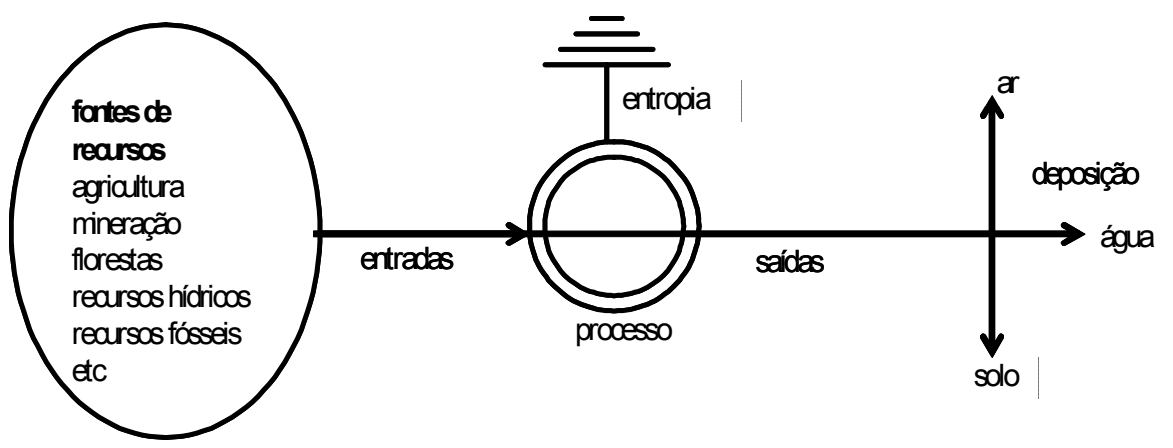

Figura 3. Esquema do padrão degenerativo. fonte: traduzido de Lyle (1994, p.5)

E propõe a substituição desse padrão pelo sistema regenerativo, onde energia e materiais sofrem contínuas transformações de um estado para outro (aludindo à primeira lei da termodinâmica) sendo que, para isso, há necessidade de que as fontes sejam continuamente 
renovadas ou regeneradas. Então, o padrão linear daria lugar a um padrão cíclico, abrangendo as fontes de recursos, consumo e descarte (Figura 4).

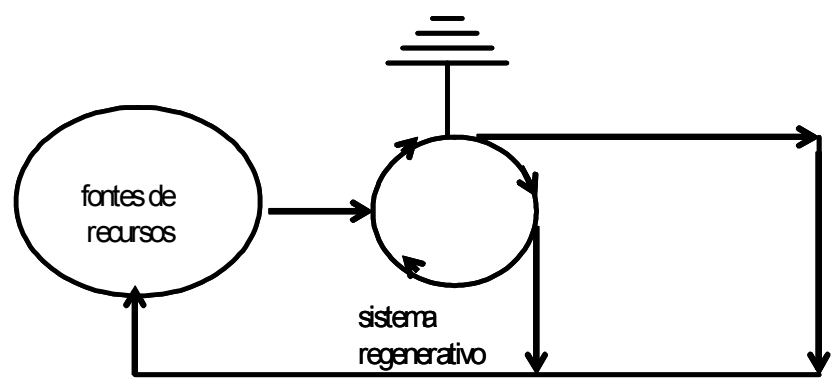

Figura 4. Esquema de padrão regenerativo fonte: traduzido de Lyle (1994, p. 10)

A visão de ciclo é também a proposta de Edwards e Bennett (2003), Henn e Fava (1994), Kibert (2003), McDonough e Braungart (2003) quando questionam a validade do conceito de "berço ao túmulo" (cradle-to-grave) e sugerem a utilização da noção de "berço ao berço" (cradle-to-cradle).

A proposta de Lyle é uma mímese do processo de regeneração natural que seria conseguida com o desenvolvimento da tecnologia. Na Figura 5 são apresentados os seis processos básicos que caracterizam a regeneração: “conversão (fotossíntese), distribuição (ventos, chuvas, movimentos migratórios de animais), filtragem (da água pelo solo, por exemplo), assimilação (biomassa e resíduos para decomposição), armazenamento (aqüíferos, petróleo) e onde o desenvolvimento humano ocorre, a reflexão humana - anima mundi (de Platão) ou noosfera (de Teilhard de Chardin). 


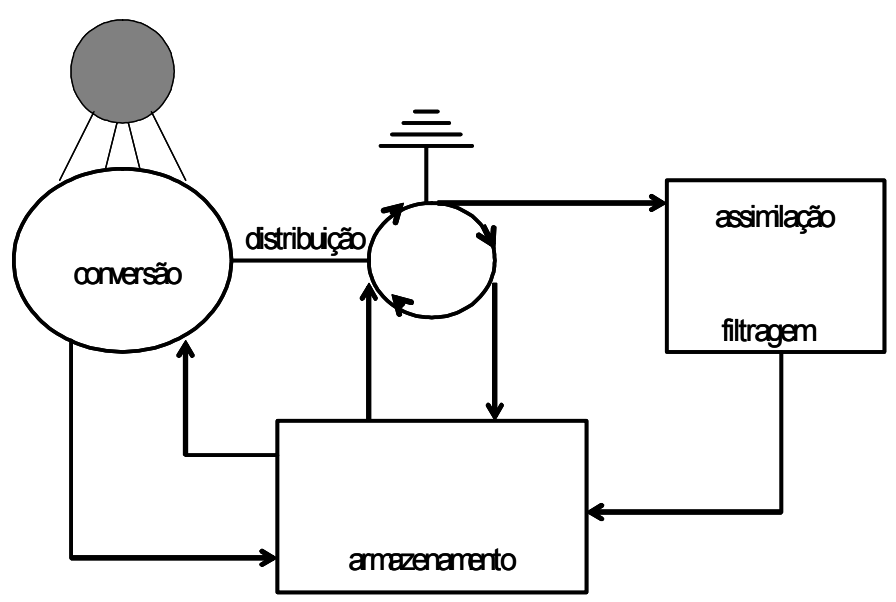

Figura 5. Fases básicas do funcionamento do ecossistema regenerativo fonte: traduzido de Lyle, 1994, p. 26

Lyle reforça que essa concepção não significa regressão para a era pré-industrial, antevendo as distorções que deram margem para associações errôneas tais como humanidade versus natureza, emprego versus ambiente (WILSON, 1996) ou "desenvolvimento" como crescimento econômico e melhoria dos padrões de vida como critica Leroy et al (2002).

Baseado nessas distorções e no predomínio das questões da dimensão ambiental, a Agenda 21 da Construção Sustentável para países em desenvolvimento descreve a falsa (fraca) e a verdadeira (forte) sustentabilidade. Da mesma forma o fazem Leroy et al., que criticam a visão parcial e cômoda do conceito comumente adotada. Dizem que essa visão é motivada por uma consciência ambiental distorcida, com postura de cumprimento do mínimo necessário e soluções paliativas de essência exploratória.

Na perspectiva da formação de uma visão de sustentabilidade para o contexto brasileiro, esses autores destacam as incompatibilidades entre muitas diretrizes de crescimento/ desenvolvimento, adotadas na realidade brasileira. A crítica ao modelo de desenvolvimento, baseado prioritariamente na dimensão econômica é a tônica da discussão.

[...] os padrões de produção e consumo dos países ditos 'do Norte' é que são apontados como os ideais desejáveis para toda a vida humana na Terra. Não somos todos iguais, [...] Não temos a mesma base material. [...] Somos pois potencialmente diferenciados nas nossas necessidades, sonhos e desejos. Tudo isso, entretanto, é negado pelos interessados em nos manterem iludidos (LEROY et al, 2002, p.14). 
CIB e UNEP-IETC evidenciam a percepção de que no desenvolver do conceito, as metas da sustentabilidade por vezes foram diminuídas, sob a justificativa da viabilidade e da adaptação aos diversos contextos de aplicação. A prática comum é reforçada pela tendência dos governos de agirem de forma imediatista, o oposto da maneira estimada pela sustentabilidade. A quantidade de problemas urgentes impede que até mesmos os órgãos de planejamento possam se dedicar às questões de longo prazo (LYLE, 1994).

"A sustentabilidade [forte] demandará mudanças fundamentais e de longo alcance na ordem da economia mundial e nas relações de poder, nos modelos de desenvolvimento, nas práticas de produção, nas atitudes em relação aos recursos e nos modos de vida" (CIB e UNEP-IETC, 2002). Dessa forma, agregam-se outros componentes àquela visão anterior, que aumentaram ainda mais a sua complexidade.

A definição para a sustentabilidade, de acordo com a Agenda 21 da Construção Sustentável para países em desenvolvimento (países com PIB per capita menor que US\$ 7000 dólares) seria

a condição ou estado que permitiria a existência do homo sapiens, provido de segurança, saúde e vida produtiva para todas as gerações em harmonia com a natureza e com os valores culturais e espirituais locais. É a meta que gostaríamos de alcançar (AGENDA 21 DA CONSTRUÇÃO SUSTENTÁVEL PARA PAÍSES EM DESENVOLVIMENTO, 2002, p.06).

A sustentabilidade é entendida como um ponto de equilíbrio e o desenvolvimento sustentável então, o caminho para o seu alcance. É

o tipo de desenvolvimento que precisamos ter para alcançar a sustentabilidade. É um processo contínuo de manutenção de um equilíbrio dinâmico entre as necessidades e demandas das pessoas pela equidade, prosperidade e qualidade de vida, e o que é ecologicamente possível (AGENDA 21 DA CONSTRUÇÃO SUSTENTÁVEL PARA PAÍSES EM DESENVOLVIMENTO, 2002, p.06).

A noção de equilíbrio dinâmico é a mesma de homeostase, sugerida por Cannon em 1939 e defendida por Lutzenberger (informação verbal) ${ }^{6}$. O modelo de retroação ou 
homeostase busca uma meta, "baseado em cadeias causais circulares e mecanismos que enviam retroativamente a informação sobre os desvios do estado a ser mantido ou da meta a ser atingida". A homeostase "ensaia diferentes modos e meios e finalmente estaciona em um campo onde não entra mais em conflito com valores críticos do ambiente" demonstrando um comportamento adaptativo (BERTALANFFY, 1977, p.73).

Construção sustentável pode então ser definida como "um processo holístico buscando restaurar e manter a harmonia entre os ambientes natural e o construído e criar assentamentos que afirmam a dignidade humana e encoraja a igualdade econômica" (CIB e UNEP-IETC, 2002). Sinteticamente, Gibberd (2004) diz que “a edificação e construção sustentáveis buscam maximizar os efeitos sociais e econômicos benéficos enquanto minimizam os impactos ambientais negativos".

A operacionalização da sustentabilidade no setor é proposta nas duas Agendas da Construção Sustentável. A Agenda 21 da Construção Sustentável (CIB, 1999) classifica os objetivos, barreiras, desafios e ações da sustentabilidade numa abordagem que mescla escalas (do material ao ambiente urbano) e dimensões (ambiental, social, econômico e cultural):

- processo e gerenciamento;

- produtos e edificações;

- consumo de recursos;

- desenvolvimento urbano;

- encargos ambientais;

- questões sociais, culturais e econômicas.

Já a Agenda 21 da Construção Sustentável para países em desenvolvimento dá importância para a equalização das dimensões e, a partir do conteúdo já desenvolvido pela primeira Agenda, aprimoram a abordagem e discutem as semelhanças e diferenças na aplicação dos princípios da sustentabilidade em países desenvolvidos e em desenvolvimento.

\subsection{Os princípios da sustentabilidade}

Para disseminar e viabilizar ações mais sustentáveis, o conceito de sustentabilidade e seus princípios são cada vez mais detalhados e regionalizados. Parte considerável desse 
empenho se deve aos desafios apontados pelos países em desenvolvimento, enfatizando a existência e importância de outros princípios da sustentabilidade de outras dimensões.

Os princípios comumente citados pela literatura referem-se às três dimensões mais conhecidas, sendo citados como "proteção ambiental", "eficiência econômica" e “equidade social" ou em termos similares, conforme observa Silva e Shimbo (2001). Esses autores propõem-se a analisar os princípios de diferentes contextos para a definição de um referencial com características básicas da sustentabilidade. O resultado é a obtenção de cinco dimensões de análise, apresentados no Quadro 1. 


\begin{tabular}{|l|l|}
\hline \multicolumn{1}{|c|}{ aspectos } & \multicolumn{1}{c|}{ princípios e estratégias gerais de sustentabilidade } \\
\hline \hline ambiental & $\begin{array}{l}\text { Manutenção da integridade ecológica por meio da prevenção das várias formas de } \\
\text { poluição, da prudência na utilização dos recursos naturais, da preservação da } \\
\text { diversidade da vida e do respeito à capacidade de carga dos ecossistemas }\end{array}$ \\
\hline social & $\begin{array}{l}\text { Viabilização de uma maior equidade de riquezas e de oportunidades, combatendo- } \\
\text { se as práticas de exclusão, discriminação e reprodução da pobreza e respeitando-se } \\
\text { a diversidade em todas as suas formas de expressão }\end{array}$ \\
\hline econômico & $\begin{array}{l}\text { Realização do potencial econômico que contemple prioritariamente a distribuição } \\
\text { de riqueza e renda associada a uma redução das externalidades socio-ambientais, } \\
\text { buscando-se resultados macrossociais positivos }\end{array}$ \\
\hline político & $\begin{array}{l}\text { Criação de mecanismos que incrementem a participação da sociedade nas tomadas } \\
\text { de decisões, reconhecendo e respeitando os direitos de todos, superando as } \\
\text { práticas e políticas de exclusão e que promovam o desenvolvimento da cidadania } \\
\text { ativa }\end{array}$ \\
\hline $\begin{array}{l}\text { Promoção da diversidade e identidade cultural em todas as suas formas de } \\
\text { expressão e representação, especialmente daquelas que identifiquem as raízes } \\
\text { endógenas, propiciando também a conservação do patrimônio urbanístico, } \\
\text { paisagístico e ambiental, que referenciem a história e a memória das comunidades }\end{array}$ \\
\hline
\end{tabular}

Quadro 1. Princípios e estratégias gerais de sustentabilidade fonte: Silva apud Silva e Shimbo (2001, p.78)

Dependendo do contexto, outras dimensões também podem ser agregadas (ética, tecnológica, estética, entre outras). Silva (2000) comenta que é comum o surgimento de termos que relacionam duas dimensões com "justiça social” que congrega valores políticos e sociais ao mesmo tempo.

Com a abertura do foco da sustentabilidade, houve um crescimento do componente humano no lugar do econômico, dado pela noção de desenvolvimento humano, a mesma que deu origem ao $\mathrm{IDH}^{7}$, elaborado com o intuito de oferecer um panorama baseado nas relações sociais ao invés das econômicas (PNUD apud CARMO e HOGAN, 1995).

Outro conceito implícito nesses princípios gerais é o conceito de trocas justas, que considera o acesso aos recursos, baseado na premissa de que todas as entradas de material na economia mundial devem ser divididas com as futuras gerações. A redução do consumo se deve não só pelo esgotamento dos recursos mas também pelo impacto ambiental gerado na extração e uso desses recursos (CIB e UNEP-IETC, 2002, p.20). 
Essas considerações agregam um nível de complexidade maior à análise de sustentabilidade, para o qual Bertalanffy julga serem mais bem abordados se entendidos como "sistemas". “Os fenômenos sociais devem ser considerados como 'sistemas', por mais difíceis e mal estabelecidas que sejam atualmente as definições das entidades sócio-culturais". "A moderna pesquisa dos sistemas pode fornecer a base de uma estrutura mais capaz de fazer justiça às complexidades e propriedades dinâmicas do sistema sócio-cultural” (BUCKLEY apud BERTALANFFY, 1977, p.23).

Conjuntamente com os princípios gerais, Silva apud Silva e Shimbo (2001) identificam um conjunto de características da sustentabilidade para serem interpretados integradamente (Quadro 2).

caráter progressivo

- Caráter de tendência: a sustentabilidade se apresenta como uma condição a ser introjetada em um processo onde se pretenda atingir determinadas metas devendo ser continuamente construída e permanentemente reavaliada;

- Caráter dinâmico: não se trata de algo tangível que se adquira definitiva e completamente, mas uma condição que deve interagir com o dinamismo da realidade em que se insere, adequandose a fatores conjunturais, estruturais ou imprevisíveis;

caráter holístico

- Caráter plural: a sustentabilidade é pluridimensional e envolve aspectos básicos tais como: ambientais, econômicos, sociais, políticos e culturais. Novas dimensões podem ser acrescentadas se o problema em questão assim o exigir;

- Caráter de indissociabilidade: além do caráter plural que pressupõe o envolvimento de vários aspectos, existe um vínculo indissociável entre eles exigindo a sua plena consideração para que se garanta uma condição sustentável;

- Caráter interdisciplinar: devido à amplitude de interações que são contempladas em suas considerações, demanda a confluência de diferentes áreas do conhecimento, tanto pra a construção de suas compreensões teóricas como de suas ações práticas;

caráter histórico

- Caráter espacial: embora a noção de sustentabilidade tenha um forte perfil de origem que valoriza as condições endógenas, ela não pode prescindir da inserção e interação dos contextos locais com os mais amplos, contemplando também as causas e conseqüências das pegadas ecológicas;

- Caráter temporal: a relação de tempo adquire uma importância fundamental no equacionamento das ações praticadas no passado, no presente e as que serão exercidas no futuro. Quando se trata do meio ambiente construído urbano, geralmente se adota o tempo social do universo antrópico;

- Caráter participativo: a preservação de uma condição sustentável tem uma forte interdependência com o aspecto da diversidade participativa dos agentes sociais, na medida em que a presença ou não deste fator pode tanto contribuir, como comprometer as metas pretendidas.

Quadro 2. Síntese de características básicas da sustentabilidade. fonte: Silva apud Silva e Shimbo (2001) 
Com base na característica de pluralidade e indissociabilidade, pode-se questionar as afirmações de que países pobres têm outras prioridades que não as ambientais, como faz Kohler e Moffatt (2003): "países em desenvolvimento têm como prioridade a solução de questões como dignidade e segurança, mais do que a redução dos impactos do ciclo de vida". Ou como faz Rovers quando afirma que "o consumo de recursos é a mais urgente de todas as preocupações relacionadas com a construção civil” (ROVERS, 2003, p.29).

Gibberd (2004) também faz uma análise similar. Diz que nos países desenvolvidos, onde a maior parte das necessidades básicas humanas já foram atendidas (e em muitos casos, excedidos), ênfase deve ser dada para a tentativa e manutenção dos padrões de vida, enquanto atuam na prevenção do esgotamento de recursos e dos danos ambientais, enquanto que nos países em desenvolvimento, a ênfase deve ser o atendimento às necessidades básicas enquanto se previne os impactos ambientais negativos. Essa postura, no entanto, isenta os países desenvolvidos da pressão econômica que exercem sobre os menos desenvolvidos e que de acordo com Leroy et al. (2002), é a principal razão da dificuldade do Brasil de alcançar um contexto mais sustentável. A análise do conceito de sustentabilidade e dos princípios básicos sugere o tratamento diferenciado entre desenvolvidos e em desenvolvimento, mas no sentido de reduzir as diferenças existentes entre si.

A própria idéia de prioridade, assim como de foco, ênfase, são discutíveis quando se prédetermina a inter-relação entre questões. Essas relações podem ser de causa e conseqüência, contradições e conflitos, que resultam na determinação de ganhos e perdas de sustentabilidade.

A compreensão das questões de sustentabilidade, quando esta deixa de ser vista meramente como um problema de caráter tecnológico, passa a demandar um conhecimento do processo histórico de maneira a possibilitar uma abordagem sistêmica do contexto. Leroy et al. (2002) debatem componentes históricos como a globalização, influência do capital estrangeiro, políticas econômicas impostas pelos países mais ricos e o enfraquecimento das políticas nacionais dos mais pobres, como determinantes das situações de crise vividas pelo país.

São observados a formação e aprofundamento de dois grandes "fossos" durante as últimas três décadas. O primeiro separa os países em desenvolvimento e os desenvolvidos, caracterizado pelas diferenças de qualidade de vida (saúde, educação, atendimento às 
necessidades básicas de infra-estrutura), grau de desenvolvimento tecnológico e poder, fortemente influenciados pelo modelo neoliberalista e pelo chamado "mito da globalização".

O segundo "fosso", nacional, torna cada vez mais evidente as diferenças entre ricos e pobres no Brasil. Os ícones dessa diferença são a condição de miserabilidade, falta de acesso a toda a infra-estrutura de educação, saúde, habitação nas áreas urbanas e rurais, e por outro lado a concentração de riqueza e de renda, os incentivos à exportação de bens de alto consumo energético e de recursos naturais e controle sobre as decisões de governo. Esses fossos, se mantidos, levarão a um quadro de total insustentabilidade e de profundas crises.

Com essa forma pluridimensional de abordagem, o potencial de contribuição de qualquer componente, seja humano ou material, para um contexto mais sustentável pode ser mais amplamente examinado.

Um grau de dificuldade é acrescido nessa visão porque o propósito da pluridimensionalidade não corresponde à maneira tradicional como o conhecimento é produzido e transferido no meio acadêmico "desde o Iluminismo", diz Lyle. "As disciplinas acadêmicas são áreas de conhecimento e habilidade estreitamente definidos, com limites protegidos invejosamente, tendo pouco a fazer com a realidade dos processos naturais". Esse autor destaca a necessidade de multi e interdisciplinaridade para definir as conexões, organizar diferentes fragmentos de informação de forma coerente, num "nível de interação entre experts capazes de lidar com possibilidades criativas de sistemas regenerativos e também suas inerentes e inevitáveis limitações” (LYLE, 1994, p.28).

1.3.1. Princípios da sustentabilidade para a totalidade do setor da construção civil

Os princípios mais relacionados com o setor da construção civil foram definidos inicialmente pela Agenda 21 e pela Agenda Habitat, de forma genérica:

Promover métodos e tecnologias localmente disponíveis, apropriados, acessíveis, seguros, eficientes e ambientalmente corretos em todos os países, particularmente nos em desenvolvimento, nos níveis local, nacional, regional e sub-regional que enfatizem o uso otimizado dos recursos humanos locais e encorajem métodos que economizam energia e que são protetores da saúde humana (THE HABITAT AGENDA, 2003). 
Essa visão estabelece um elo entre tecnologia e lugar, introduzindo muitos outros valores além da eficiência e custo no processo de produção do ambiente construído.

Posteriormente, as Agendas específicas do setor - Agenda 21 da Construção Sustentável, elaborada por CIB (1999) e Agenda 21 da Construção Sustentável para países em desenvolvimento, elaborada por CIB e UNEP-IETC (2002) - contribuíram com princípios mais detalhados e também para a melhor delimitação do próprio setor. A ISO também está desenvolvendo padrões de sustentabilidade na construção civil - princípios gerais, terminologia e indicadores de sustentabilidade, dos quais somente os ambientais foram finalizados (ISO, 2004).

Na primeira Agenda, houve uma preponderância das questões ambientais sobre as demais, que permaneceram genéricas como as proposições iniciais. Com a segunda Agenda, as dimensões social, econômica, política e cultural foram mais detalhadas, a partir da explicitação dos problemas comuns aos países em desenvolvimento.

Acompanhando essa tendência, outras publicações também têm definido com maior grau de precisão, os princípios, desafios, ações e estratégias nas diferentes dimensões da sustentabilidade. Os quadros seguintes destinam-se a apresentá-los, tendo sido extraídos e reunidos de acordo com as dimensões preponderantes, a partir das publicações mais recentes sobre o tema.

$\mathrm{Na}$ dimensão ambiental, o estágio de desenvolvimento atual mostra princípios mais delimitados, estratégias e uma grande definição de ações. Princípios definidos especificamente para cada agente do setor têm sido cada vez mais comuns. Para Lyle, o principal vetor para a redução de impactos ambientais é o desenvolvimento e resgate de tecnologias mais amigáveis, contrariando em parte a posição de outros autores que dizem que a tecnologia não é a chave da solução do problema "ambiente/ recursos". Mas, diferente da tecnologia atual, a "nova tecnologia" não é linear e não é paliativa, considera o contexto global e na essência reproduz os processos de regeneração naturais.

$\mathrm{Na}$ abordagem em escala nacional, os princípios ambientais freqüentemente citados são apresentados no Quadro 3. 
reduzir o uso de recursos em todo o ciclo de vida:

- reduzir a produção de resíduos;

- promover a eficiência energética na produção e nas edificações;

- reduzir o consumo de água;

- reduzir a exploração de minérios;

- aumentar a durabilidade;

- aumentar a manutenção.

reduzir a liberação de emissões ambientalmente perigosas:

- reduzir a emissão de gases tóxicos que contribuem para o efeito estufa;

- reduzir a emissão de efluentes.

promover o funcionamento saudável dos ecossistemas, em escala local, regional e global:

- desenvolver pesquisas sobre os impactos ao meio ambiente causados por materiais e acabamentos;

- desenvolver estratégias para lidar com materiais perigosos.

vencer a barreira da inércia tecnológica dos países em desenvolvimento;

vencer a dependência tecnológica em relação aos países desenvolvidos;

vencer a falta de políticas de suporte às tecnologias nacionais:

- inovar os materiais e métodos de construção.

melhorar a qualidade do processo de construção e seus produtos.

adotar o conceito de sistema regenerativo.

incentivar o desenvolvimento e a difusão de tecnologias ambientalmente sustentáveis.

Quadro 3. Princípios ambientais da construção sustentável.

fonte: CIB (1999), ISO apud Strand e Fossdal (2003), CIB e UNEP-IETC (2002), Instituto Ethos (2004a)

A Agenda 21 da Construção Sustentável para países em desenvolvimento nota que a inércia tecnológica foi causada pela introdução não questionada dos códigos de obra e conceitos de planejamento dos países ocidentais na época da colonização; situação que foi agravada com as sucessivas crises enfrentadas pelos países em desenvolvimento. Leroy et al. (2002) dizem que, ao mesmo tempo, "os países de primeiro mundo passaram a melhor organizar suas cadeias produtivas, acompanhadas por avanços tecnológicos, a tal ponto que em curto prazo, em alguns setores, se inviabilizam as transferências de tecnologia”.

Bunn (2003) lembra a existência de muitos outros fatores além da eficiência energética a serem considerados para garantir a real eficiência da transferência de tecnologia para países 
em desenvolvimento. Soluções eficientes em apenas um ou outro aspecto são deficientes e correm risco maior de falhar. Aspectos ressaltados pelo autor são a adequação ao clima, detalhamento, instalação e verificação corretas, nível de complexidade compatível com a compreensão por parte dos usuários.

Pela representatividade na economia de uma região, é demandada do setor a contribuição para a redução da pobreza e das desigualdades dentro da população e a busca de soluções para as questões de discriminação, características da construção civil.

Wells lida com os aspectos sociais da construção sustentável nos países em desenvolvimento, analisando as normas de trabalho da OIT e leis de cada país. Observa que os trabalhadores de países em desenvolvimento caracteristicamente são provenientes do interior, não têm muita educação ou habilidades desenvolvidas e são desorganizados e não cientes dos seus direitos.

A "responsabilidade social", assim como denominam Wells e o Instituto Ethos, é definida por como a "minimização de efeitos negativos e maximização dos efeitos positivos que uma atividade econômica exerce sobre as pessoas e a sociedade" (WELLS, 2003). No ambiente empresarial, a responsabilidade social é definida como "iniciativas tomadas por uma empresa - independentemente se relativo à produção de produtos ou serviços - que são direcionados para aprimorar o desempenho ou imagem da empresa em termos de cidadania corporativa" (MULLINS, 1994). O impacto se dá em três escalas:

- nos envolvidos na atividade;

- na comunidade local;

- na comunidade global (mínimos).

O Pacto Global aborda a dimensão social com princípios das áreas de direitos humanos (base: Declaração Universal de Direitos Humanos) e relações de trabalho (base: Declaração da OIT sobre os Princípios e Direitos Fundamentais do Trabalho). Esses princípios e outros abordados na literatura, referentes ao setor, que contribuem para delinear a sustentabilidade social são apresentados no Quadro 4. 
promover ambiente de trabalho saudável e seguro:

- desenvolver pesquisas sobre impactos à saúde por materiais de construção e de acabamento;

- desenvolver pesquisa de impactos causados pelas atividades de obra;

- apoiar e respeitar a proteção de direitos humanos reconhecidos internacionalmente;

- assegurar sua não-participação em violações dos direitos humanos;

- apoiar a eliminação de todas as formas de trabalho forçado ou compulsório;

- apoiar a erradicação efetiva do trabalho infantil;

- apoiar a igualdade de remuneração e a eliminação da discriminação no emprego.

atendimento às necessidades dos usuários no futuro:

- promover flexibilidade e adaptabilidade.

capacitar e encorajar a consciência e o aprendizado contínuo dentro e fora das organizações do setor privado para implementar ações mais sustentáveis:

- elaborar campanhas de informação sobre uso de produtos mais sustentáveis;

- desenvolver treinamento;

- desenvolver parcerias com instituições de pesquisa e educação;

- apoiar programas de capacitação.

promover habitação saudável e segura:

- considerar acessibilidade universal.

Quadro 4. Princípios sociais da construção sustentável.

fonte: CIB (1999), CIB e UNEP-IETC (2002), Instituto Ethos (2004a)

Para a definição dos princípios econômicos, a Agenda 21 da Construção Sustentável para países em desenvolvimento estabelece uma leitura das barreiras à maior sustentabilidade nesses países, seguindo uma abordagem de caráter histórico. Analisa as incertezas do ambiente econômico, devido à influência do capital externo do Primeiro Mundo sobre a economia interna dos países pobres e imposições sobre as condições de importação/ exportação, que ajudam a manter um cenário econômico dependente e de grandes variações. Trocas injustas envolvendo commodities primárias (recursos naturais) e produtos industrializados são criticados em CIB e UNEP-IETC (2002) e em Leroy et al (2002).

Com isso, compreende-se a dificuldade de implantação de um planejamento estratégico para a sustentabilidade, adiado pelas sucessivas crises financeiras no entorno da esfera governamental e pela falta de continuidade dos compromissos políticos assumidos. 
Leroy et al. (2002) demonstram a preocupação com a "desnacionalização" de setores produtivos brasileiros, abertos ao capital estrangeiro. Isso contribui para a "transferência dos centros de decisão" e também das iniciativas de inovação tecnológica, enfraquecendo ainda mais o papel nacional. Observam também que ao passo que a exportação é incentivada, retira-se o apoio aos pequenos empreendimentos, observáveis na dificuldade de acesso a financiamentos, a contração de dívidas e o corte de incentivos aos empreendimentos.

De mesmo cunho, “a canalização de recursos públicos para a viabilização de empreendimentos grandiosos (hidrelétricas, estradas) ou para a promoção de empreendimentos de grande capital, que se caracterizam pela alta concentração fundiária, mecanização e uso extensivo de agrotóxicos, contraria a lógica anterior da produção difusa, feita por numerosos pequenos proprietários" (LEROY et al, 2002). As prioridades criadas para o cumprimento dos acordos feitos com os países de primeiro mundo, que envolvem a parcela mais rica da população, refletem na dificuldade de atendimento às demandas da parcela mais pobre, como o caso da habitação própria.

Ao mesmo tempo, a consciência ambiental nos países desenvolvidos surge como uma oportunidade de negócio, ao contrário de "ameaças" como eram vistas no passado (HIRSCHHORN, 1994, p.35), com reflexos na fabricação dos produtos.

As questões que resultam da análise de fatos como os apresentados apóiam a elaboração dos princípios econômicos apresentados no Quadro 5.

Os incentivos à economia local são um exemplo do potencial do setor da construção civil como influência positiva para a geração de uma economia forte e diversificada. Os resultados positivos desse apoio arrolados por Gibberd são: redução dos custos de transporte, redução da poluição, reforço das relações entre as pessoas e o lugar em que vivem (Gibberd, 2004).

O trabalho de desenvolvimento local, através da vertente econômica, implica também em lidar com a organização e participação da população, as lideranças políticas, a prestação de contas transparente à comunidade beneficiada, o incentivo ao empreendedorismo, o apoio a micro e pequenos empreendimentos individuais e coletivos que viabilizem novos negócios que gerem empregos ou ocupações produtivas e à criação de mecanismos para aumentar a autonomia do lugar (SEBRAE, 1999). 
princípio/ desafio/ ação e estratégias da dimensão econômica da construção sustentável

capitalizar sobre os benefícios da sustentabilidade para aumentar os lucros:

- elaborar serviços diferenciados.

considerar a consciência ambiental como um fator de competitividade:

- mudar o design, composição e embalagem dos produtos para oferecer benefícios ambientais e criar produtos totalmente novos para repor os antigos;

- mudar os materiais usados na indústria para reduzir o uso de substâncias tóxicas que podem ser usados somente no processamento e que podem permanecer nos produtos;

- fazer melhoramentos em todos os processos, tecnologias, operações e procedimentos para reduzir e eliminar a geração de todos os resíduos na sua fonte. outros setores também devem mudar, incluindo a produção de energia, agricultura e transporte.

mobilizar recursos para apoiar pesquisas, mudanças tecnológicas e estudos de adequação para a produção e comercialização de novos materiais e tecnologias:

- conciliar recursos públicos com recursos privados e setor acadêmico para promover iniciativas;

- realizar parcerias para pesquisa entre países para reduzir custos e tempo.

avaliar riscos e benefícios da mudança para práticas mais sustentáveis:

- incorporar procedimentos de contabilidade de todos os custos no desenvolvimento das edificações e bens construídos (custos diretos iniciais, custos sociais e ambientais diretos e indiretos).

encorajar e apoiar a implementação de práticas mais sustentáveis:

- criar a demanda por materiais e serviços ambiental e socialmente mais responsáveis;

- combater a corrupção.

promover habitação com custos acessíveis.

Quadro 5. Princípios econômicos da construção sustentável.

fonte: CIB (1999), CIB e UNEP-IETC (2002), ISO apud Strand e Fossdal (2003), Hirschhorn (1994)

Para a sustentabilidade política na construção civil, a questão geral é sobre a falta de integração entre os agentes, que não se identificam como partes de um mesmo setor. Componente político característico do Brasil é a descrença no regime democrático que se instaurou ao longo da última década, com a conseqüente despolitização da população, influenciando também a credibilidade dos movimentos organizados. "O impacto conjugado da desigualdade crescente e da falta de crença na efetividade dos canais da transformação social pela via da ação coletiva organizada não podia deixar de minar as bases da credibilidade da própria instituição democrática” (LEROY et al., 2002). Qualquer esforço a favor de um horizonte mais sustentável necessita compreender a conexão entre tais questões.

A representação deficiente dos interesses de alguns agentes tomadores de decisão (governos locais, construtores, usuários e órgãos de legislação) prejudica a 
operacionalização da pluridimensionalidade, provocando o desequilíbrio de importância entre dimensões. E os restantes planejadores urbanos, arquitetos, engenheiros, incorporadores, fornecedores e produtores, apesar de bem representados, raramente se mostram abertos à cooperação para o objetivo comum da sustentabilidade (BAKENS, 2003).

Rovers (2003) diz que há uma urgente necessidade de inovação, idéias e desenvolvimento de novas políticas para promover a sustentabilidade no setor, já que "poucas políticas ou seus instrumentos voltados para o setor têm estimulado o progresso além do nível atingido pelas leis". Observa que em países em desenvolvimento, políticas rigorosas não são tão fáceis de serem aplicadas pela situação irregular de muitas empresas, impossibilitando por exemplo a aplicação de medidas fiscais.

Porém, tanto CIB e UNEP-IETC quanto Leroy et al comentam que as políticas públicas têm sido negativamente influenciadas, em conseqüência do cenário econômico atual, pela a adoção cada vez mais crescente de medidas de caráter emergencial e em escala local.

Sociedades e governos que se deparam com questões extremas de sobrevivência, comuns nos países em desenvolvimento, tendem a adotar uma abordagem de gerenciamento da crise para o desenvolvimento, considerando pouco os impactos em longo prazo de suas ações no ambiente e na sociedade (CIB e UNEP-IETC, 2002, p. 21).

Leroy et al acrescentam ainda a dificuldade de incutir a preocupação ambiental em uma população empobrecida e sem condições mínimas de infra-estrutura.

Num ambiente empresarial, a busca da excelência ambiental, de saúde e de segurança, tem "tarefas críticas", baseadas principalmente em ações da dimensão política (postura, envolvimento, comunicação) e social (aprendizado) (GREENO, 1994). O autor cita como exemplos a resistência à mudança, os impedimentos hierárquicos e as responsabilidades vagas.

“A conscientização consiste em dar uma contribuição para que as pessoas percebam que nenhum ser humano vale mais ou menos que os demais e que todos podem e devem lutar constantemente pela conquista ou preservação da liberdade de pensar e de agir e pela igualdade de oportunidades e responsabilidades." (DALLARI, op.cit., p.51). "O trabalho de organização consiste em colaborar concretamente, fornecendo idéias ou meios materiais, para que grupos humanos conjuguem seus esforços visando objetivos comuns". Mas o 
autor esclarece que o organizador não deve assumir a posição de líder ou tutor do grupo, para permitir que o grupo independentemente possa tomar suas decisões e assumir suas responsabilidades.

princípio/ desafio/ ação e estratégias da dimensão política da construção sustentável

organizar as partes interessadas para conquistar a possibilidade de participar ativamente das decisões:

- assumir uma definição e terminologia-chave clara e consensual do setor que inclua todos os agentes e que os faça sentirem-se parte dessa cadeia, com responsabilidade de se unirem;

- representar equilibradamente todos os tomadores de decisão nos debates internacionais sobre o setor;

- unir esforços de cooperação dentro do próprio setor para a busca de recursos para lidar com as questões decisivas e para a criação de estratégias para atender aos requisitos da sustentabilidade.

mudar os valores organizacionais da empresa:

- apoiar a liberdade de associação e o reconhecimento efetivo do direito à negociação coletiva.

constituir parcerias e cooperação para desenvolvimento e implementação de ações para construção sustentável:

- cooperar na implementação das ações de pesquisa e desenvolvimento;

- constituir parcerias com instituições de pesquisa.

demandar sustentabilidade:

- estabelecer critérios de sustentabilidade para aquisição de produtos também nas grandes empresas e governo.

monitorar e avaliar:

- desenvolver e adotar relatório de responsabilidade social corporativa;

- participar de processos de certificação;

- coletar informação para monitoramento e avaliação.

criar direcionadores para a maior sustentabilidade:

- encorajar o desenvolvimento de comunidades altamente estruturadas, internamente relacionadas e mutuamente apoiadas.

adotar uma abordagem preventiva para os desafios ambientais.

desenvolver iniciativas para promover maior responsabilidade ambiental:

- questionar e mudar os padrões de consumo;

- questionar e mudar os próprios impactos;

- usar novas tecnologias e processos em suas próprias atividades.

Quadro 6. Princípios políticos da construção sustentável. fonte: Bakens (2003); CIB (1999), Dallari (1994), CIB e UNEP-IETC (2002)

O aumento da participação pública além de influenciar as ações sobre o meio ambiente, recupera a consciência que vem sendo gradativamente perdida de que o ser humano está inserido numa série de interconexões naturais e artificiais e ajuda a educar para as questões ambientais. 
A discussão sobre a sustentabilidade cultural também remonta à independência dos valores dos "países colonizadores", com a recuperação de materiais e técnicas nativas e seu aprimoramento. Para viabilizar esse cenário, é discutida também a rejeição dos usuários, que almejam os padrões modernos. Os princípios apresentados no Quadro 7 foram extraídos das oportunidades, apresentadas na Agenda 21 da Construção Sustentável para países em desenvolvimento.

princípio/ desafio/ ação e estratégias da dimensão cultural da construção sustentável

reavaliar o tradicional:

- resgatar a capacidade de trabalho em mutirão;

- adequar materiais e técnicas tradicionais ao contexto contemporâneo.

superar a resistência aos materiais e técnicas nativos:

- viabilizar econômica e tecnologicamente e as técnicas tradicionais para recuperar a confiança dos usuários.

recuperar valores éticos para o planejamento da construção e assentamento.

combinar o tradicional e o moderno:

internalizar a sustentabilidade:

- abandonar a idéia de que a sustentabilidade é apenas "uma variável positiva a mais" nos empreendimentos;

- aumentar a percepção dos usuários para as questões de sustentabilidade.

Quadro 7. Princípios culturais da construção sustentável. fonte: CIB (1999), CIB e UNEP-IETC (2002)

O desenvolvimento sustentável como um todo requer que essas dimensões sejam contempladas conjuntamente. Focalizando a implantação de novos empreendimentos, o PRODER Especial arrola os seguintes requisitos para o desenvolvimento local integrado e sustentável (DLIS) (SEBRAE, 1999):

- participação da administração pública local;

- transferência de recursos exógenos e mobilização de recursos endógenos;

- participação de agentes de desenvolvimento governamentais, empresariais, da sociedade civil, voluntários e remunerados;

- população despertada para as possibilidades e as vantagens de um processo mais solidário de desenvolvimento, através de estratégias de comunicação social e marketing;

- diversidade e complementaridade como nova dinâmica econômica integrada de base local. 
1.3.2. Princípios, desafios e estratégias para os processos da cadeia produtiva dos materiais de construção

No caso dos materiais de construção, se ultrapassada a abordagem tecnológica do ciclo de vida, torna-se visível o seu papel na modificação de cenários locais e regionais, na definição do caráter da economia, da qualidade de vida da população e podendo interferir na definição das políticas habitacionais. O envolvimento deixa de ser somente o dos agentes diretamente relacionados com o processo produtivo e a discussão incorpora toda a cadeia produtiva e ainda outras cadeias produtivas indiretamente relacionadas.

Tanto CIB (1999) quanto CIB e UNEP-IETC (2002) arrolam as ações de acordo com os agentes responsáveis. $\mathrm{Na}$ Agenda 21 da Construção Sustentável para países em desenvolvimento são definidos cinco grupos principais de agentes:

- Setor de pesquisa e educação;

- Setor privado, empresas de serviço público e outros provedores de serviço: profissionais liberais, prestadores de serviço, construtoras, fabricantes de materiais de construção, componentes e ferramentas, o setor de financiamento para construção e edificações, órgãos governamentais específicos;

- Clientes: usuários individuais a grandes grupos;

- Governo e órgãos de controle: governos locais e nacionais, organizações de padronização e controle das atividades dos profissionais e indústria;

- Organizações não governamentais e organizações sociais de interesse público.

Diferente da primeira Agenda, a segunda dedica atenção para a definição de ações específicas para os organismos governamentais, pela sua importância no desenvolvimento de cenários mais sustentáveis dos países em desenvolvimento.

O entendimento dos princípios gerais para todo o setor da construção civil e os que serão apresentados neste item, que são específicos de cada processo, devem ser entendidos de forma complementar. 


\begin{tabular}{|c|c|}
\hline dimensão & princípio/ desafio/ ação e estratégias para os organismos governamentais \\
\hline \multirow[t]{4}{*}{ ambiental } & $\begin{array}{l}\text { introjetar o questionamento da visão linear dos fluxos naturais das políticas para a } \\
\text { sustentabilidade do setor da construção civil: } \\
\text { - } \quad \text { substituir subsídios ultrapassados para a indústria, mineração, transporte e novas } \\
\text { edificações por medidas de apoio a ciclos fechados para todos os materiais e } \\
\text { produtos } \\
\text { - } \quad \text { elaborar programas e leis para recuperação de áreas de mineração }\end{array}$ \\
\hline & $\begin{array}{l}\text { demandar produtos ambientalmente mais amigáveis dos fornecedores: } \\
\text { - desenvolver normas, padrões ou medidas e incentivos fiscais }\end{array}$ \\
\hline & - definir padrões de qualidade para materiais reciclados \\
\hline & - elaborar políticas para "desmaterialização" (desmontagem ou desconstrução) \\
\hline \multirow[b]{2}{*}{ social } & $\begin{array}{l}\text { viabilizar difusão do conhecimento: } \\
\text { - disponibilizar recursos para treinamento e educação dos membros da construção } \\
\text { civil, em todos os níveis }\end{array}$ \\
\hline & $\begin{array}{l}\text { constituir parcerias e cooperação: } \\
\text { - } \quad \text { incluir o setor informal nos programas elaborados } \\
\text { - } \quad \text { envolver lideranças formais e não formais para aumentar a consciência e } \\
\text { disseminação da informação entre a população } \\
\text { - } \quad \text { estabelecer parcerias com governos locais para capacitarem-se, apoiarem a } \\
\text { implementação de ações de pesquisa e desenvolvimento e para gerenciarem e } \\
\text { controlarem a transferência de tecnologia dos programas de pesquisa para } \\
\text { projetos-piloto }\end{array}$ \\
\hline econômica & $\begin{array}{l}\text { disponibilizar recursos financeiros: } \\
\text { - } \text { reconsiderar o escopo dos próprios programas de financiamento, visando apoiar } \\
\text { mais pesquisas que contribuam para a melhoria da qualidade de vida da } \\
\text { população } \\
\text { - negociar termos melhores e acesso a financiamentos externos } \\
\text { - disponibilizar financiamentos para apoiar novos empreendimentos e tecnologias } \\
\text { inovadoras }\end{array}$ \\
\hline \multirow[b]{2}{*}{ política } & $\begin{array}{l}\text { capacitar-se para a sustentabilidade: } \\
\text { - criar um conselho para formular guias para a construção sustentável } \\
\text { - } \quad \begin{array}{l}\text { aumentar a consciência entre as lideranças e outros políticos para compreender e } \\
\text { tomar decisões para mudar as políticas, legislação e implementação da construção } \\
\text { sustentável }\end{array}\end{array}$ \\
\hline & $\begin{array}{l}\text { provocar mudanças internas: } \\
\text { - } \text { dar exemplos } \\
\text { - } \text { adotar uma estrutura de controle para a construção sustentável (códigos de } \\
\text { conduta) } \\
\text { - } \text { atender aos acordos internacionais dos quais o país é signatário } \\
\text { - } \text { mudar o sistema de cobrança dos serviços dos profissionais para encorajar o uso } \\
\text { - de práticas mais sustentáveis } \\
\text { - } \text { mudar os critérios de aquisição de materiais e produtos } \\
\text { demandar produtos e serviços mais sustentáveis e não apoiar empreendimentos }\end{array}$ \\
\hline
\end{tabular}


continuação...

\begin{tabular}{|c|c|}
\hline dimensão & princípio/ desafio/ ação e estratégias para os organismos governamentais \\
\hline \multirow[t]{2}{*}{ política } & $\begin{array}{l}\text { encorajar e apoiar a implementação: } \\
\text { - } \quad \text { mudar os padrões e leis que podem representar obstáculos para a construção } \\
\text { sustentável } \\
\text { - disponibilizar incentivos e penalidades eficientes } \\
\text { - impor leis }\end{array}$ \\
\hline & $\begin{array}{l}\text { monitorar e avaliar: } \\
\text { - definir estruturas legais para monitoramento e avaliação } \\
\text { - } \quad \text { participar de esquemas de monitoramento e avaliação }\end{array}$ \\
\hline
\end{tabular}

Quadro 8. Princípios da construção sustentável para os organismos governamentais. fonte: CIB e UNEP-IETC (2002), Rovers (2003), CIB (1999)

O papel das ONGs e OSCIPs para a promoção da construção sustentável é o de atuar como intermediador entre os vários agentes, catalisando as transferências de tecnologia, a conscientização dos diferentes grupos ou a defesa de direitos (CIB e UNEP-IETC, 2002).

\subsubsection{Processo de exploração dos recursos naturais}

$\mathrm{Na}$ visão do conceito é esperado que esse processo considere em geral a redução do esgotamento dos recursos não renováveis, os impactos causados na exploração e a taxa de consumo.

A madeira de plantios florestais tem um conjunto de princípios específicos, elaborados para os processos de certificação de florestas, como a desenvolvida pelo FSC (2000). Edgar diz que quando é intensiva, a produção madeireira deve ser tratada como uma forma de "agricultura industrial", com implicações sociais e ambientais de acordo com a natureza, localização, inputs, níveis de cuidado na produção, outputs e padrões de distribuição da indústria.

As questões relativas aos materiais em geral e à madeira especificamente são apresentadas conjuntamente no Quadro 9. Questões de outras dimensões, não comumente citados nas avaliações de sustentabilidade sobre a exploração dos recursos florestais, como motivação e engajamento para a implantação de sistemas agroflorestais (LIMA, 1993, Ferguson e Dargavel, 1978) ou o valor estético da paisagem para os moradores de um lugar (EDGAR, 1978) são também apresentados. 
O FSC apresenta os princípios políticos conjuntamente com os princípios da dimensão social e caracterizam-se por serem mais operacionalizados que os outros princípios apresentados. Cada um dos princípios FSC apresentados tem critérios e indicadores para monitoramento.

Os processos de certificação internacionalmente mais conhecidos são o FSC e a ISO $^{8}$ e as derivadas iniciativas nacionais e regionais cada vez mais crescentes $\left(\mathrm{SCS}^{9}, \mathrm{GT}^{10}\right.$, American Tree Farm System, SFI ${ }^{11}$ e SmartWood - Estados Unidos; CSA ${ }^{12}$ - Canadá; SGS-Forestry e Soil Association - Reino Unido e Finnish Forest Certification System - Finlândia) (KIEKENS, 1999).

O foco é o monitoramento das práticas de gerenciamento florestal no nível da floresta, através de auditorias e concessão de certificados. Os sistemas regionais são valorizados pela distinção de alguns aspectos como a participação pública da CSA, o atendimento às necessidades de proprietários privados não industriais do GT e mesmo como alternativa à marca internacional FSC feita pelo PEFC ${ }^{13}$.

Diferentemente do FSC, a ISO não desenvolveu um padrão específico de produção florestal internacional, mas um documento de especificação que pode ser usado para propósitos de auditoria e certificação, os relatórios ISO/ TR 1406 - "Informações para auxílio às organizações florestais no uso da ISO 14001" e ISO 14004 "Padrões de sistemas de gerenciamento ambiental". A ISO 14001 é caracterizada por requerer a implementação de um sistema de gerenciamento ambiental, cumprindo três acordos: atendimento às leis e regras, melhoramento contínuo e prevenção da poluição. E, também diferente do FSC, os objetivos de desempenho são definidos pela organização florestal.

Kiekens ainda analisa a eficiência da certificação no melhoramento do gerenciamento de florestas, os efeitos na comercialização de produtos florestais e a capacidade da certificação de aprimorar a informação e escolha do consumidor (KIEKENS, 2000).

O paradoxo citado por Kiekens é que a necessidade de certificação de florestas surgiu e cresceu a partir das preocupações com a devastação de florestas tropicais, mas atualmente os maiores usuários desses processos são as grandes indústrias dos países mais desenvolvidos (EUA, Canadá, Suécia, Finlândia e Polônia particularmente) que já tinham

\footnotetext{
${ }^{8}$ ISO - International Organization of Standardization

${ }^{9}$ SCS - Scientific Certification Systems

${ }^{10}$ GT - Green Tag Forestry

${ }^{11}$ SFI - Sustainable Forestry Initiative verification program

${ }^{12}$ CSA - Canadian Standards Association sustainable forestry certification system
} 
uma capacidade instalada considerável. $\mathrm{O}$ total de pequenas propriedades privadas e comunidades florestais não chega a 10\% das áreas certificadas, mesmo havendo diretrizes relativas à certificação de grupo de pequenos proprietários rurais desenvolvidas pelo FSC (KIEKENS, 2000). As críticas ao processo de certificação de florestas citadas por Kiekens incluem os altos custos da obtenção de certificação para pequenos proprietários (citando o exemplo da Bélgica, onde existem aproximadamente 100.000 produtores com 2,5 hectares cada) e a criação de processos discriminatórios de produtos não certificados.

\begin{tabular}{|c|c|}
\hline dimensão & e estratégias para o processo de exploração de recursos \\
\hline \multirow[b]{4}{*}{ ambiental } & reduzir o esgotamento dos recursos minerais. \\
\hline & $\begin{array}{l}\text { reduzir a devastação das florestas nativas: } \\
\text { - } \quad \text { elaborar programas de reposição; } \\
\text { - } \quad \text { combater a erosão e o assoreamento dos rios. }\end{array}$ \\
\hline & $\begin{array}{l}\text { conservar a diversidade ecológica e seus valores associados, os recursos hídricos, os solos, } \\
\text { os ecossistemas e paisagens frágeis e singulares. }\end{array}$ \\
\hline & $\begin{array}{l}\text { definir um programa de manejo sustentável de florestas plantadas: } \\
\text { - } \quad \text { escrever, implementar e atualizar um plano de manejo apropriado à escala e } \\
\text { intensidade das operações propostas. Descrever claramente os objetivos de longo } \\
\text { prazo do manejo florestal e os meios para atingi-los; } \\
\text { - conduzir monitoramento apropriado à escala e intensidade do manejo florestal para } \\
\text { que sejam avaliados a condição da floresta, o rendimento dos produtos florestais, a } \\
\text { cadeia de custódia, as atividades de manejo florestal e seus impactos ambientais e } \\
\text { sociais; } \\
\text { manter ou incrementar os atributos que definem as florestas de alto valor de } \\
\text { conservação. Decisões relacionadas à florestas de alto valor de conservação devem } \\
\text { sempre ser consideradas no contexto de uma abordagem de precaução; } \\
\text { - planejar e manejar as plantações de acordo com os princípios do FSC. Complementar } \\
\text { o manejo, reduzir as pressões e promover a reabilitação e conservação das florestas } \\
\text { nativas. }\end{array}$ \\
\hline \multirow{3}{*}{ social } & combater as desigualdades sociais, empobrecimento e desemprego. \\
\hline & $\begin{array}{l}\text { reconhecer e respeitar os direitos legais e costumários das comunidades indígenas e } \\
\text { comunidades tradicionais de possuir, usar e manejar suas terras, territórios e recursos. }\end{array}$ \\
\hline & $\begin{array}{l}\text { manter ou ampliar, em longo prazo, o bem estar econômico e social dos trabalhadores } \\
\text { florestais e das comunidades locais. }\end{array}$ \\
\hline econômica & $\begin{array}{l}\text { incentivar o uso eficiente e otimizado dos múltiplos produtos e serviços da floresta } \\
\text { (plantações florestais) para assegurar a viabilidade econômica e uma ampla gama de } \\
\text { benefícios ambientais e sociais. }\end{array}$ \\
\hline
\end{tabular}

continua... 
continuação...

\begin{tabular}{|c|l|}
\hline dimensão & \multicolumn{1}{c|}{ princípio/ desafio/ ação e estratégias para o processo de exploração de recursos } \\
\hline \multirow{5}{*}{ política } & $\begin{array}{l}\text { assegurar aos trabalhadores os direitos de organização e negociação voluntária de seus } \\
\text { interesses. } \\
\text { manter processos de consulta com as pessoas e grupos diretamente afetados pelas } \\
\text { operações de manejo florestal. } \\
\text { manter e comprovar a existência de informação e oportunidade clara de participação } \\
\text { da(s) comunidade(s) local(is) diretamente afetada(s) pelas operações de manejo florestal e } \\
\text { consideração de suas perspectivas quanto aos aspectos que diretamente afetam sua } \\
\text { qualidade de vida. }\end{array}$ \\
\hline \multirow{5}{*}{ legal } & $\begin{array}{l}\text { o manejo florestal deve respeitar todas as leis aplicáveis ao país onde opera, os tratados } \\
\text { internacionais e os acordos assinados por este país e obedecer a todos os princípios e } \\
\text { critérios do FSC. }\end{array}$ \\
\cline { 2 - 3 } & $\begin{array}{l}\text { definir claramente, documentar e estabelecer legalmente as posses de longo prazo e os } \\
\text { direitos de uso sobre a terra e recursos florestais. }\end{array}$ \\
& $\begin{array}{l}\text { respeitar os valores estéticos de um lugar: } \\
\text { compreender o valor da paisagem e de suas alterações (colheita drástica, aparência } \\
\text { ordenada, mudanças de cheiro, ruídos, temperatura e ventos) para a comunidade } \\
\text { local; } \\
\text { criar responsabilidade estética - consideração dos impactos na floresta com os } \\
\text { padrões regionais (quando e onde ocorre a produção florestal, a população atingida, } \\
\text { outros elementos estéticos da área, as atitudes atuais e gosto). }\end{array}$ \\
\hline
\end{tabular}

Quadro 9. Princípios da construção sustentável para o processo de exploração de recursos. fonte: CIB (1999), CIB e UNEP-IETC (2002), Martinez (1998), Strand e Fossdal (2003), Lyle (1994), FSC (2000), Edgar (1978)

\subsubsection{Processo de fabricação de materiais de construção}

Nesse processo ainda sobressaem as questões de cunho técnico no desenvolvimento dos princípios. Nos países em desenvolvimento, a tendência é de que esse processo seja cada vez mais visto como uma oportunidade de geração de trabalho e de renda, para a melhoria das condições de vida em escala local e também regional.

O CIB (1999) delimita nitidamente o processamento dos materiais, definindo ações para a sustentabilidade ambiental para os fabricantes de materiais. Já CIB e UNEP-IETC (2002) definem ações de variados aspectos para uma gama maior de agentes.

$\mathrm{Na}$ cadeia produtiva da madeira, corresponde ao processo de "usinagem". Uma das maiores críticas à madeira nesse processo é a baixa taxa de conversão de matéria-prima em produtos finais, que resulta na produção de grande quantidade de sub-produtos e resíduos. Mas com a valorização da madeira, alternativas de utilização vêm sendo pesquisadas e praticadas tanto para um quanto para outro. 
Os princípios identificados para o processo de fabricação de materiais são apresentados no Quadro 10.

\begin{tabular}{|c|c|}
\hline dimensão & princípio/ desafio/ ação e estratégias para o processo de fabricação \\
\hline \multirow{6}{*}{ ambiental } & $\begin{array}{l}\text { aumentar sua responsabilidade sobre os impactos ambientais: } \\
\text { - receber seus produtos usados para reciclagem (logística de reciclagem de ciclo } \\
\text { fechado); } \\
\text { - } \quad \text { atuar como intermediador para comercialização dos resíduos da demolição, para } \\
\text { facilitar a reciclagem. }\end{array}$ \\
\hline & $\begin{array}{l}\text { minimizar os danos ambientais causados pelas suas operações: } \\
\text { - } \quad \text { reduzir a degradação das fontes de extração de matérias primas; } \\
\text { - } \quad \text { aumentar o uso de resíduos reciclados como matéria-prima. }\end{array}$ \\
\hline & $\begin{array}{l}\text { considerar o ciclo de vida como base para o desenvolvimento dos produtos: } \\
\text { - } \quad \text { estabelecer parcerias com projetistas para criar novos desenhos: técnicas de ligação e } \\
\text { montagem, padronização, modulação, facilidade de desmontagem/ reutilização, } \\
\text { aptidão para conserto, adaptação; } \\
\text { - } \quad \text { aumentar a durabilidade de materiais e técnicas nativas; } \\
\text { - } \quad \text { produzir materiais recicláveis ou reutilizáveis; } \\
\text { - } \quad \text { estender a vida útil; } \\
\text { - } \quad \text { desenvolver ferramentas melhoradas de previsão de vida útil de componentes e } \\
\text { sistemas; } \\
\text { - constituir parcerias entre produtores para elaborar novos componentes } \\
\text { multifuncionais. }\end{array}$ \\
\hline & $\begin{array}{l}\text { reduzir a quantidade de material e energia incorporada nos produtos: } \\
\text { - utilizar materiais locais, matérias-primas renováveis; } \\
\text { - } \quad \text { reciclar com baixo consumo de energia; } \\
\text { - utilizar materiais de baixo consumo energético. }\end{array}$ \\
\hline & $\begin{array}{l}\text { informar os usuários: } \\
\text { - desenvolver sistemas on-line de informação sobre produtos (qualidades ambientais, } \\
\text { detalhes sobre as condições de uso e reciclagem). }\end{array}$ \\
\hline & $\begin{array}{l}\text { reduzir as emissões de produtos em uso: } \\
\text { - } \quad \text { utilizar materiais não tóxicos. } \\
\text { evitar o uso de madeira tratada com CCA e ACA }{ }^{14} \text { para aplicações onde há evidência } \\
\text { de lixiviação inaceitável (tanques de água, coberturas de reservatório, bebedouros e } \\
\text { silos); } \\
\text { - considerar a real necessidade de tratamento; } \\
\text { - limpar toda a serragem e entulho e dispor em local adequado. Se o destino for a } \\
\text { queima, os produtos tratados com creosoto podem ser queimados a céu aberto, mas } \\
\text { as cinzas de madeira tratada com CCA, CCB e outros apresentam sais metálicos que } \\
\text { podem poluir o local de descarte, sendo necessário consultar o fabricante do produto } \\
\text { sobre qual a melhor maneira de fazê-lo. }\end{array}$ \\
\hline
\end{tabular}


continuação...

\begin{tabular}{|c|c|}
\hline dimensão & princípio/ desafio/ ação e estratégias para o processo de fabricação \\
\hline social & $\begin{array}{l}\text { - dar preferência para materiais e técnicas de alta demanda de mão-de-obra; } \\
\text { - usar EPI's quando cortar ou beneficiar madeira tratada, fazer esse trabalho em } \\
\text { ambiente aberto para evitar a contaminação do ar interior com o pó de serra; } \\
\text { - depois de trabalhar com a madeira tratada, lavar-se antes de comer, beber ou fumar; } \\
\text { - não usar madeira tratada em local que pode contaminar alimento ou água para } \\
\text { consumo humano ou animal. }\end{array}$ \\
\hline \multirow[t]{2}{*}{ econômica } & $\begin{array}{l}\text { disponibilizar financiamentos: } \\
\text { - destinar parte dos recursos de financiamento privado para pesquisas de interesse } \\
\text { comum. }\end{array}$ \\
\hline & $\begin{array}{l}\text { encorajar e apoiar a implementação de práticas mais sustentáveis: } \\
\text { - } \quad \text { apoiar através de incubação e orientação de novos nichos de mercado. }\end{array}$ \\
\hline política & $\begin{array}{l}\text { constituir parcerias e cooperação para desenvolvimento e implementação de ações para } \\
\text { construção sustentável: } \\
\text { - formar coligações industriais para desenvolver soluções integradas e de ganhos } \\
\text { mútuos. }\end{array}$ \\
\hline
\end{tabular}

Quadro 10. Princípios da construção sustentável para o processo de fabricação. fonte: CIB (1999), CIB e UNEP-IETC (2002), Cooper (1993), Lepage e Cavalcante (1986)

\subsubsection{Processo de projeto}

Esse processo vem sendo cada vez mais considerado como um dos mais importantes na tomada de decisões para a sustentabilidade, visível na quantidade de métodos de avaliação que a consideram. Tendem a tratar o processo de projeto como uma atividade cada vez mais participativa englobando além dos projetistas (arquitetos e engenheiros), os usuários e demais clientes (CIB, 1999; KIBERT, 2003, ISO apud STRAND e FOSSDAL, 2003).

Nos países em desenvolvimento, que sempre discutem o provimento de habitação social, a melhoria das condições das favelas e autoconstrução, a participação dos usuários é uma questão a ser trabalhada para reduzir o preconceito e rejeição a técnicas nativas, que agregam o símbolo do "primitivismo, subdesenvolvimento e pobreza" (CIB e UNEPIETC, 2002). A origem desse comportamento está associada ao período colonial, com a imposição de códigos de obra e conceitos de planejamento dos países colonizadores. 
Entretanto, proporcionar esse nível de discussão requer vencer barreiras como a formação de sub-grupos, a partidarização política, o paternalismo e o clientelismo (Martínez, 1998) para atingir metas mais justas.

$\mathrm{Na}$ discussão sobre os materiais "mais adequados" para os países mais pobres, Edwards e Bennett falam do necessário equilíbrio na utilização de materiais de construção "globais" (o cimento, aço, alumínio, vidro e madeira) e "locais" (tijolo, solo cimento, madeira local, bambu e outros produtos renováveis), considerando o conforto interno, o relativo impacto ambiental benéfico e a produção de habitação (EDWARDS e BENNETT, 2003, p.58).

Mas a questão é operacionalizar esse equilíbrio em meio a uma cultura popular que busca alcançar o status de moderno dos países desenvolvidos, usando materiais nobres alumínio, aço, concreto, enquanto técnicas de construção locais se perdem.

Essa discussão ainda deve considerar os requisitos gerais, que valem tanto para países desenvolvidos quanto em desenvolvimento. Na definição do Environmental Building News, produtos “verdes" são os que (WILSON, 2000):

- são feitos a partir de matérias-primas ambientalmente amigáveis;

- são "verdes" pelo que não contêm;

- reduzem os impactos ambientais durante a construção, reforma ou demolição;

- reduzem os impactos ambientais do uso da edificação;

- contribuem para um ambiente interno saudável e seguro.

A dimensão cultural ainda debate a valorização das raízes da população, a abordagem dos símbolos (de ascensão social, progresso material, estabilidade), soluções "caseiras", métodos de construção tradicionais, vocabulário de arquitetura tradicional, recursos pictóricos, formas tradicionais, qualidade estética, valores da comunidade, mitos, questões de religião (CIB e UNEP-IETC, 2002) como meios de motivação para aumentar a participação da população no projeto.

Os princípios citados na literatura sobre esse processo são apresentados no Quadro 11. 


\begin{tabular}{|c|c|}
\hline dimensão & princípio/ desafio/ ação e estratégias para o processo de projeto \\
\hline \multirow[t]{2}{*}{ ambiental } & $\begin{array}{l}\text { abordar o projeto de forma integrada, considerando desde a fase de exploração dos } \\
\text { recursos até a reciclagem: } \\
\text { - } \quad \text { estabelecer parcerias entre projetistas e com produtores para desenvolver novos } \\
\text { conceitos de construção: componentes leves e novas técnicas de ligação e } \\
\text { montagem, como faz o CYTED }{ }^{15} \text {; } \\
\text { - introduzir rótulos ambientais para identificar fatores de interesse como a } \\
\text { expectativa de vida útil, conteúdo energético, composição e potencial de } \\
\text { reciclagem; } \\
\text { - especificar materiais de fontes renováveis, materiais recicláveis, reutilizáveis, de } \\
\text { baixo conteúdo energético, não tóxicos, duráveis e que não comprometam a } \\
\text { saúde dos usuários; } \\
\text { - considerar a manutenção na fase de projeto projetar prevendo desmontagem, } \\
\text { adotando sistemas abertos, técnicas avançadas de ligação e montagem, dimensões } \\
\text { padronizadas; } \\
\text { - incorporar os sistemas regenerativos no projeto; } \\
\text { (madeira) considerar as características das peças a serem detalhadas para adequar } \\
\text { o projeto às medidas das peças disponíveis no mercado com o objetivo de evitar } \\
\text { perdas por cortes e emendas desnecessárias. }\end{array}$ \\
\hline & $\begin{array}{l}\text { desenvolver consciência ambiental e capacitação para as questões ambientais: } \\
\text { - desenvolver ferramentas de projeto ambiental, como a utilização da tecnologia da } \\
\text { informação para estabelecer um fluxo de informação com constante } \\
\text { retroalimentação. }\end{array}$ \\
\hline \multirow{3}{*}{ social } & incorporar no processo de projeto os impactos sociais. \\
\hline & $\begin{array}{l}\text { inovar os materiais de construção e métodos para dar melhores condições de } \\
\text { habitação, principalmente para a parcela mais carente da população: } \\
\text { - buscar alternativas aos materiais tradicionais, baratos e com aproveitamento dos } \\
\text { recursos locais, seja de fontes renováveis ou de resíduos industriais e da } \\
\text { agricultura; } \\
\text { - diferenciar as tecnologias que melhor se destinam para cada tipo de produção e } \\
\text { para cada padrão de consumo (local ou nacional). }\end{array}$ \\
\hline & $\begin{array}{l}\text { - compreender a sustentabilidade. } \\
\text { - compreender as mudanças que o conceito traz para a indústria. }\end{array}$ \\
\hline \multirow[b]{2}{*}{ econômica } & $\begin{array}{l}\text { encorajar e apoiar a implementação de práticas mais sustentáveis: } \\
\text { - criar a demanda por materiais e serviços ambiental e socialmente mais } \\
\text { responsáveis. }\end{array}$ \\
\hline & $\begin{array}{l}\text { - (usuários) considerar o balanço entre custos financeiros e outros custos (social, } \\
\text { ambiental) para escolha dos produtos. } \\
\text { - monitorar os custos, economias e outros benefícios e impactos resultantes da } \\
\text { compra e uso de produtos e serviços sustentáveis para motivar outros usuários a } \\
\text { adotarem procedimento similar e conseqüentemente expandir o mercado. } \\
\text { - utilizar o monitoramento para desenvolver sistemas de compra mais eficientes. }\end{array}$ \\
\hline
\end{tabular}

continua...

${ }^{15}$ CYTED - Programa Ibero-americano de Ciencia y Tecnología para el Desarrollo. Programa de fomento internacional e multilateral de cooperação científica e tecnológica para a investigação aplicada de materiais e técnicas inovadoras para o contexto dos países iberoamericanos, com vistas à transferência aos sistemas produtivos e às políticas sociais dos países participantes (HABYTED-CYTED, s.d. $\operatorname{pg} 3)$ 
continuação...

\begin{tabular}{|c|c|}
\hline dimensão & princípio/ desafio/ ação e estratégias para o processo de projeto \\
\hline \multirow{3}{*}{ política } & $\begin{array}{l}\text { fortalecer as instituições de planejamento em todos os níveis, do global ao local: } \\
\text { - reorganizar as instituições de planejamento. }\end{array}$ \\
\hline & $\begin{array}{l}\text { encorajar a maior equidade, colaboração, responsabilidade e o aprimoramento } \\
\text { contínuo, centralizados na pessoa, contribuindo para um projeto democrático de } \\
\text { administração descentralizada e "superando o papel de simples beneficiários das } \\
\text { medidas governamentais": } \\
\text { - criar mecanismos para participação da sociedade mobilizada; } \\
\text { - assegurar as inter-relações e articulação entre atores; } \\
\text { - participar plenamente associado às autoridades governamentais, a tomada de } \\
\text { decisões em conjunto, o compartilhamento com o estado na responsabilidade } \\
\text { solidária na coesão social, coerência urbana, prestação de serviços públicos; } \\
\text { - questionar a simples lógica de eficiência e não só contestar e reivindicar mas } \\
\text { propor disponibilizar sistemas de informação sobre produtos ambientais para os } \\
\text { usuários. }\end{array}$ \\
\hline & $\begin{array}{l}\text { (usuários) demandar produtos ambientalmente mais amigáveis dos fornecedores: } \\
\text { - definir concretamente as especificações ambientais dos produtos (materiais } \\
\text { renováveis, recicláveis, reutilizáveis, de fácil desmontagem, de dimensões } \\
\text { padronizadas, baixo conteúdo energético e não tóxicos) e das edificações, } \\
\text { utilizando-as como critérios de seleção. }\end{array}$ \\
\hline \multirow{3}{*}{ cultural } & $\begin{array}{l}\text { reavaliar o tradicional: } \\
\text { - compreender as características positivas das construções vernaculares (uso de } \\
\text { materiais naturais, próximos, baratos e acessíveis); } \\
\text { - elaborar novas técnicas adequadas à atual realidade. }\end{array}$ \\
\hline & $\begin{array}{l}\text { valorizar e aumentar a vida útil de materiais e tecnologias de construção tradicionais } \\
\text { nativas, ao invés de substituí-los por técnicas importadas. }\end{array}$ \\
\hline & $\begin{array}{l}\text { equilibrar a utilização de tecnologias nativas, utilizadas em autoconstruções, e a } \\
\text { produção de pré-fabricados em escala para atender à habitação social. }\end{array}$ \\
\hline
\end{tabular}

Quadro 11. Princípios da construção sustentável para o processo de projeto fonte: CIB (1999), CIB e UNEP-IETC (2002), Ag. Habitat apud Martinez (1998), Strand e Fossdal (2003), Lyle (1994), I. Ethos (2004c)

\subsubsection{Processo de construção}

Esse processo pode ser realizado englobando diferentes conjuntos de operações, das mais artesanais àquelas completamente industrializadas. Diferente da abordagem adotada na primeira Agenda 21 da Construção Sustentável (CIB, 1999) que relaciona os desafios do processo limitando-se às empreiteiras, construtoras e prestadores de serviço, a segunda Agenda explora mais a fundo a autoconstrução e as questões em torno.

O foco nesse processo para o contexto de países mais pobres tem aumentado, ultrapassando o enfoque ambiental tradicional, como o proporcionado pelos critérios do LEED e outros métodos de avaliação ambiental de materiais e edificações. São discutidas questões de geração de empregos, justiça no ambiente de trabalho, saúde, segurança, além 
da maior participação dos trabalhadores nas decisões. Tende a ser visto cada vez mais como uma oportunidade de capacitação e realização.

O propósito dessa abordagem é a transformação do ambiente dos canteiros de obras em países pobres, caracterizado por Wells como ambientes de pouca segurança, apresentando doenças ocupacionais, com trabalhos mal remunerados, discriminatórios, hostis e cujos contratantes ignoram suas obrigações. A corrupção e outras condições de ilegalidade também são características das empresas envolvidas com a construção, o que, na visão de Rovers (2003) influencia a inércia na adoção de opções mais sustentáveis. “O verdadeiro progresso requer que todos respeitem as mesmas regras, e para isso é preciso uma ação coordenada de todas as partes interessadas" (WELLS, 2003).

A Pesquisa da Atividade Econômica Paulista 2001 verificou que o mercado de trabalho na construção civil cresce, mas nas grandes empresas do setor; e que as pequenas empregam menos, geram pouco valor e têm menor competitividade (MATTEO apud IZIQUE, 2004). Com base nessa informação, é sugerido nesse documento que as políticas públicas voltadas para pequenas empresas de serviço focalizem a competitividade do negócio a invés do emprego para surtir mais efeito (IZIQUE, 2004). Essa recomendação pode ser contestada se levados em consideração os pontos de vista dos diversos agentes envolvidos (empregador, empregado).

A cadeia produtiva da madeira na região sudoeste do Estado acompanha esse cenário, cabendo às pequenas empresas uma representatividade cada vez menor na economia da região, ao passo que grandes indústrias têm se instalado e fortalecido.

A realidade da produção de habitação informal é destacada nas publicações internacionais sobre sustentabilidade da construção civil como um indicador de possíveis caminhos a serem tomados para viabilizar a produção de habitações de melhor qualidade (VOINSON e CASTAGNÉ, 1988; SUSTAINABLE DEVELOPMENT TASK FORCE, 2003). Nem sempre a produção em escala é vista positivamente, já que em sua essência “conduz a uma economia centralizada e crescimento desigual enquanto a micro produção facilita a distribuição de riqueza e poder” (CIB e UNEP-IETC, 2002, p. 19, grifo meu).

Nessa linha, a construção de habitações em madeira é vista como uma oportunidade de negócio para pequenos empreendimentos em torno da habitação e seus componentes, constituindo-se em mais uma alternativa econômica para incrementar e diversificar a atividade produtiva local, além de ser oportunidade também para a capacitação de mão-deobra e de usuários para a construção e manutenção. 
Um dos mecanismos criados para aumentar a consciência para a sustentabilidade é a internalização de "custos ambientais" e "sociais" e seus reflexos nos produtos (CIB, 1999), mas para Leroy et al essa solução não figura como uma boa alternativa.

[A] solução econômica está presente quando se propõe incluir nos preços dos produtos os custos ambientais; para os defensores dessa visão, atribuir valor ao meio ambiente e torná-lo propriedade privada seriam a melhor maneira de preservá-lo. Ora, só o exemplo da Amazônia, em que a privatização da terra faz-se acompanhar de maior destruição, já desmonta essa afirmação (LEROY et al, 2002).

Recentemente, princípios sociais específicos para empresas construtoras foram elaborados pelo Instituto Ethos, para o contexto brasileiro e propostos em consulta pública. O conteúdo dos indicadores de responsabilidade social resultantes, são apresentados conjuntamente com outros princípios arrolados para o processo de construção, contidos nos referenciais analisados, no Quadro 12.

\begin{tabular}{|c|c|}
\hline dimensão & princípio/ desafio/ ação e estratégias para o processo de construção \\
\hline ambiental & $\begin{array}{l}\text { minimizar os danos ambientais causados pelos seus processos de produção: } \\
\text { - } \text { definir operações, logística, sub-contratados e fornecedores de materiais e } \\
\text { - } \text { produtos de acordo com a noção e prontidão para as questões ambientais; } \\
\text { cliente na definição de requisitos durante o processo de construção para evitar a } \\
\text { produção de resíduos de obra; } \\
\text { - pesquisar os impactos causados por atividades de obra (perda de solo e } \\
\text { - } \text { vegetação, poluição sonora e ambiental, armazenamento de produtos perigosos); } \\
\text { - elaborar política de compra de madeiras somente de empresas que possam } \\
\text { comprovar a origem das mesmas, seja por meio de certificação legal (FSC, SOF, } \\
\text { CERFLOR etc) ou de um plano de manejo aprovado pelo IBAMA, com a } \\
\text { apresentação de nota fiscal e documento de transporte; } \\
\text { utilizar espécies de madeiras alternativas às tradicionais que se encontram sob } \\
\text { pressão de exploração; } \\
\text { (EUA) usar pelo menos } 50 \% \text { de madeira e produtos de madeira certificados pelo } \\
\text { FSC, para os componentes (mas não se limitando a) estrutura, piso, acabamento, } \\
\text { mobiliário e estruturas temporárias como fôrmas, tapumes e escoras. }\end{array}$ \\
\hline
\end{tabular}




\begin{tabular}{|c|c|}
\hline dimensão & princípio/ desafio/ ação e estratégias para o processo de construção \\
\hline \multirow{3}{*}{ ambiental } & $\begin{array}{l}\text { melhorar a qualidade do processo de construção (eficiência e segurança) e de seus } \\
\text { produtos: } \\
\text { - nos países desenvolvidos: prever a vida útil, desenvolver procedimentos de } \\
\text { reforma que causem distúrbios mínimos para os usuários e vizinhança, } \\
\text { desenvolver sistemas modulares para reforma. }\end{array}$ \\
\hline & $\begin{array}{l}\text { reduzir o uso de recursos: } \\
\text { - } \text { utilizar materiais produzidos localmente para reduzir os impactos ambientais e } \\
\text { (mínimo de } 20 \% \text {, ideal de } 50 \% \text { - porcentagens definidas para o contexto } \\
\text { americano); } \\
\text { - } \text { rotular componentes para facilitar a remoção seletiva e reciclagem; } \\
\text { - } \quad \text { aumentar o uso de subprodutos como materiais de construção; } \\
\text { - demandar e utilizar materiais com algum conteúdo de material reciclado pós- } \\
\text { - } \text { rensumo e também pós-industrialização (mínimo de } 5 \% \text {, ideal de } 10 \% \text { ); } \\
\text { materiais (mínimo de } 5 \% \text {, ideal de } 10 \% \text { ); } \\
\text { reduzir o uso de recursos finitos e de ciclos de vida extensos, substituindo-os por } \\
\text { materiais rapidamente renováveis (colhidos em ciclos de } 10 \text { anos ou menos); } \\
\text { - } \text { construir prevendo desmontagem, utilizando abordagem modulada; } \\
\text { minimizar entradas e saídas de materiais. } \\
\text { - destinar os resíduos de construção de acordo com as possibilidades para a } \\
\text { reciclagem e outras formas de aproveitamento que sejam diferentes da deposição } \\
\text { final em aterros (mínimo de } 50 \% \text {, ideal de } 75 \% \text { ); }\end{array}$ \\
\hline & $\begin{array}{l}\text { estimular o gerenciamento ambiental responsável de florestas: } \\
\text { - utilizar madeira e produtos de madeira que atendem aos princípios e critérios do } \\
\text { FSC para peças estruturais, fechamentos e acabamentos. }\end{array}$ \\
\hline \multirow{3}{*}{ social } & $\begin{array}{l}\text { criar empregos: } \\
\text { - dar preferência para métodos de construção de alta demanda de mão-de-obra. }\end{array}$ \\
\hline & $\begin{array}{l}\text { atender aos padrões da OIT }{ }^{16} \text { : } \\
\text { - } \quad \text { permitir a livre escolha (sem trabalho forçado); } \\
\text { - } \quad \text { combater o trabalho infantil; } \\
\text { - } \quad \text { promover equidade nos termos e condições de emprego. } \\
\text { - } \quad \text { promover o direito de organização e negociação coletiva dos trabalhadores. }\end{array}$ \\
\hline & $\begin{array}{l}\text { respeitar o indivíduo: } \\
\text { - } \quad \text { valorizar a diversidade. }\end{array}$ \\
\hline
\end{tabular}

continua... 
continuação...

\begin{tabular}{|c|c|}
\hline dimensão & princípio/ desafio/ ação e estratégias para o processo de construção \\
\hline \multirow{3}{*}{ social } & $\begin{array}{l}\text { manter trabalho decente: } \\
\text { - } \quad \text { estabelecer cuidados com a saúde, segurança e condições de trabalho; } \\
\text { - } \quad \text { estabelecer comportamento frente a demissões. }\end{array}$ \\
\hline & $\begin{array}{l}\text { Ser responsável frente às gerações futuras: } \\
\text { - } \quad \text { comprometer-se com a melhoria da qualidade ambiental; } \\
\text { - promover educação e conscientização ambiental; } \\
\text { - } \quad \text { promover desenvolvimento sustentável no setor de construção civil; } \\
\text { - participar de projetos sociais governamentais; } \\
\text { - } \quad \text { estabelecer critérios de utilização de madeira. }\end{array}$ \\
\hline & $\begin{array}{l}\text { Encorajar movimentos “socialmente inclusivos": } \\
\text { - produzir manuais de uso e manutenção para edificações e sistemas, informar os } \\
\text { clientes dos impactos ambientais inerentes à construção - para garantir a } \\
\text { participação deles nas metas ambientais. }\end{array}$ \\
\hline \multirow{4}{*}{ econômica } & $\begin{array}{l}\text { apoiar a economia da região: } \\
\text { - utilizar materiais produzidos localmente. }\end{array}$ \\
\hline & $\begin{array}{l}\text { Encorajar e apoiar a implementação de práticas mais sustentáveis: } \\
\text { - } \quad \text { apoiar através de incubação e orientação de novos nichos de mercado. }\end{array}$ \\
\hline & $\begin{array}{l}\text { Tornar a produção mais eficiente: } \\
\text { - gerar maior qualidade, menos desperdício de matéria-prima e menos resíduos de } \\
\text { construção e demolição. }\end{array}$ \\
\hline & $\begin{array}{l}\text { Disponibilizar financiamentos: } \\
\text { - destinar parte dos recursos de financiamento privado para pesquisas de interesse } \\
\text { comum. }\end{array}$ \\
\hline \multirow[t]{2}{*}{ política } & $\begin{array}{l}\text { constituir parcerias e cooperação para desenvolvimento e implementação de ações } \\
\text { para construção sustentável: } \\
\text { - formar coligações entre empresas para desenvolver soluções integradas e de } \\
\text { ganhos mútuos; } \\
\text { - selecionar, avaliar e estabelecer parcerias com fornecedores. }\end{array}$ \\
\hline & $\begin{array}{l}\text { Auto-regular a conduta: } \\
\text { - } \quad \text { estabelecer compromissos éticos. }\end{array}$ \\
\hline
\end{tabular}

continua... 


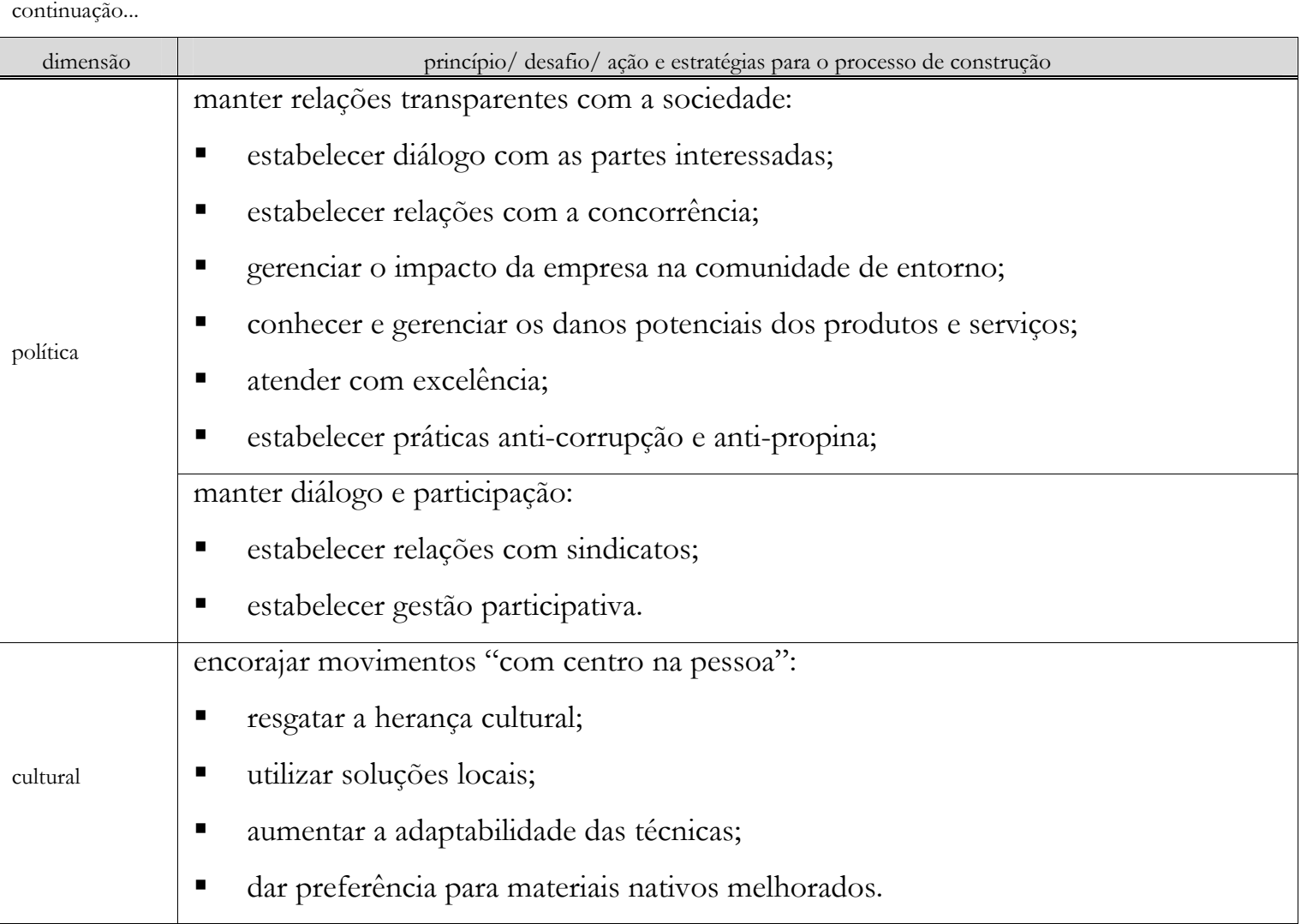

Quadro 12. Princípios da construção sustentável para o processo de construção. fonte: CIB (1999), CIB e UNEP-IETC (2002), Instituto Ethos (2004b, 2004c), LEED (2002)

\subsubsection{Uso/ manutenção}

Essa fase, também chamada de "operação" pelas publicações internacionais, é explorada principalmente pelo alto consumo de energia característico dos países de clima mais frio, emissões provocadas pelo consumo de fontes energéticas de base fóssil e pelas condições de habitabilidade proporcionadas no ambiente interno (emissões de produtos em uso, conforto ambiental). Nos países desenvolvidos, freqüentemente empresas de manutenção e "gerentes de condomínio", além dos usuários são alvo de estratégias mais sustentáveis na literatura. Secundariamente, as questões de satisfação dos usuários são também consideradas.

Essa fase é a mais longa de todo o ciclo de vida da habitação, em que todos os resultados dos processos anteriores são postos à prova. Por isso, para a habitação em madeira é essencial a realização da análise mais abrangente, para compreender alguns componentes característicos do cenário brasileiro em relação a esse material. Oliveira e Heineck (1998) identificam a falta de estudos que agreguem todos os aspectos e suas inter-relações na 
influência da satisfação dos usuários em relação a suas habitações. O conceito de satisfação é ligado ao desempenho e ao atendimento às expectativas pessoais para os autores.

Para a habitação em madeira essa fase é crítica, pelos indícios claros da rejeição pela madeira como principal componente na cultura de construção nacional. Os elos entre a fase de uso e os processos da cadeia produtiva são explorados no Capítulo 4, ainda que na forma de hipóteses, dado o baixo enfoque científico sobre o assunto.

\begin{tabular}{|c|c|}
\hline dimensão & princípio/ desafio/ ação e estratégias para a fase de uso \\
\hline \multirow{4}{*}{ ambiental } & $\begin{array}{l}\text { encarar as questões ambientais como um aspecto do conforto e conseqüentemente } \\
\text { como um fator que afeta a produtividade do uso dos espaços. }\end{array}$ \\
\hline & $\begin{array}{l}\text { desenvolver procedimentos próprios no uso da edificação para serem ambientalmente } \\
\text { corretos. }\end{array}$ \\
\hline & manter a qualidade do ambiente construído. \\
\hline & $\begin{array}{l}\text { (empresas de manutenção) ver a consciência ambiental como um fator de } \\
\text { competitividade: } \\
\text { - mostrar iniciativas; } \\
\text { - retroalimentar os clientes sobre as questões ambientais; } \\
\text { - desenvolver parcerias com fornecedores; }\end{array}$ \\
\hline social & gerenciar a saúde do ambiente interno. \\
\hline \multirow[t]{2}{*}{ político } & $\begin{array}{l}\text { capacitar-se para a sustentabilidade: } \\
\text { - criar o mercado para a construção sustentável; } \\
\text { - criar parcerias para aprendizagem; } \\
\text { - formar grupos de consumidores para influenciar o desenvolvimento de produtos e } \\
\text { serviços. }\end{array}$ \\
\hline & $\begin{array}{l}\text { incluir a sustentabilidade nas práticas: } \\
\text { - mudar os hábitos cotidianos; } \\
\text { - demandar produtos e serviços mais sustentáveis e não apoiar empreendimentos } \\
\text { que não atendem aos princípios. }\end{array}$ \\
\hline cultural & $\begin{array}{l}\text { tornar a sustentabilidade base das decisões: } \\
\text { - resgatar valores culturais na tradição que enfatizam o uso equilibrado dos recursos } \\
\text { naturais. }\end{array}$ \\
\hline
\end{tabular}

Quadro 13. Princípios da construção sustentável para a fase de uso. fonte: CIB (1999), CIB e UNEP-IETC (2002)

\subsubsection{Processo de desconstrução}

A importância desse processo está no seu potencial para reduzir um dos problemas mais significativos da construção sustentável - a produção de grande quantidade de resíduos. 
A inserção da visão de ciclo em todos os processos, mas principalmente neste, concebe a "demolição" como um processo de "desmontagem" de componentes para serem adequadamente separados visando reuso, reaproveitamento ou reciclagem. Quanto menor o cuidado nesse processo, mais resíduos sem possibilidade de reaproveitamento serão criados, implicando num maior consumo de recursos virgens para a produção de materiais em todas as cadeias produtivas da construção civil.

Nesse ponto, a madeira apresenta uma característica natural de aptidão para a desmontagem e remontagem, por ter geralmente conexões pregadas, parafusadas ou cavilhadas.

O enfoque nesse processo é principalmente ambiental, dado que todos os referenciais consultados tratam exclusivamente da realidade de países desenvolvidos. Para o Brasil, a oportunidade de geração de novos negócios (como empresas de demolição e reciclagem) também poderia ser incluída na análise. A relação entre esse processo e os demais é abordada no Capítulo 4.

O foco do CIB (1999) sobre a desconstrução é sobre as empresas de demolição, mas analisando a realidade de países em desenvolvimento, é necessário considerar também a participação dos próprios usuários. Nas várias dimensões, os princípios e estratégias citados são:

\begin{tabular}{|c|c|}
\hline dimensão & princípio/ desafio/ acão e estratégias para o processo de desconstrução \\
\hline \multirow[t]{2}{*}{ ambiental } & $\begin{array}{l}\text { minimizar os danos ambientais causados pelas suas operações: } \\
\text { - desenvolver novas técnicas de separação de componentes para facilitar a reciclagem } \\
\text { e reuso. }\end{array}$ \\
\hline & substituir a noção de "demolição" por "desconstrução" ou "desmontagem". \\
\hline
\end{tabular}

Quadro 14. Princípios da construção sustentável para o processo de desconstrução. fonte: CIB (1999), Rovers (2003), Kibert (2003)

No ponto de discussão atual, diversas escalas são abordadas pelos princípios da construção sustentável. Há os que se aplicam ao setor como um todo, os elaborados para os materiais de construção e ainda, os específicos para a madeira. A forma de classificação também é variada. Na Agenda 21 da Construção Sustentável, os princípios são organizados ora pelos agentes, ora pela fase do ciclo de vida e vários princípios aplicam-se a mais de uma fase. 
Em relação à dimensão, muitos princípios são híbridos de duas ou mais dimensões (político-cultural, político-ambiental, sócio-ambiental entre outros), mas a análise dos dados deste Capítulo mostra que o conceito original de sustentabilidade ainda é abordado de forma parcial. Há nítida ênfase das questões ambientais, perceptível pelo grau de aprofundamento dos princípios, estratégias e ações apresentados, ao passo que questões de outras dimensões, apesar de serem citadas, são menos trabalhadas. Strand e Fossdal (2003, p.36), quando analisam as leis, regulamentações e normas sobre edificações sustentáveis, observam que o desenvolvimento de indicadores lida somente com alguns aspectos. "Os sócio-econômicos em particular, recebem atenção mínima”. As questões de países em desenvolvimento não são tratadas "satisfatoriamente", apesar de sua importância ter crescido.

Genérica e sucintamente, são citados assuntos como a importância da contribuição do setor para a redução da pobreza, governo, justiça, equidade, participação, educação e mais ações relativas a políticas (ROVERS, 2003; STRAND e FOSSDAL, 2003), estratégias (SUSTAINABLE DEVELOPMENT TASK FORCE, 2003; MCDONOUGH e BRAUNGART, 2003). Cole apud Huovila (2001) afirma que apenas aumentando o escopo das considerações além dos aspectos ambientais incluindo os econômicos, sociais e institucionais, será possível estabelecer uma real avaliação de sustentabilidade.

Mas a constatação mais importante mostra que o entendimento do caráter de pluridimensionalidade também está restrito, com abordagens estanques, sem relação entre as dimensões. Embora seja uma das características da sustentabilidade, o debate da pluridimensionalidade ainda está segregado a uma abordagem conceitual, sendo pouco abordado nas estratégias, das mais gerais às específicas. "Mesmo que hoje haja um entendimento maior no nível conceitual sobre a necessidade de integrar políticas para o desenvolvimento e para o meio ambiente, ainda existe um grande vazio entre a prática e a retórica” (STEER e WADE-GERY, 1994).

Então, em relação à expectativa apresentada no final do Capítulo 1, da formação de uma perspectiva macro das questões de sustentabilidade para aplicação na cadeia produtiva, observa-se apenas o início das preocupações nesse sentido. Os trabalhos mais recentes da revista Industry and Environment (PNUMA ${ }^{17}$, 2003) concluem que o desenvolvimento de tecnologias, mesmo aplicadas na realidade, por si só não trouxe uma mudança considerável do cenário do setor em relação à sustentabilidade. Considerações como "[A]s soluções 
envolvem mudanças maiores [...]", “[...] é necessário envolver os atores [...]", “[...] necessidade de políticas [...]”, começam a aparecer também para os países desenvolvidos, diante de contextos “[...] sem grandes mudanças", são mais freqüentes.

Em função dessa constatação, o Capítulo 3 explora a discussão sobre complexidade e pluridimensionalidade, presente em conceitos afins à sustentabilidade, e a forma como a pluridimensionalidade é trabalhada em métodos de avaliação de sustentabilidade, com a perspectiva de reunir informações para efetuar a abordagem mais ampliada da cadeia produtiva da habitação em madeira de plantios florestais. 


\section{CAPÍTULO 2}

\section{A CADEIA PRODUTIVA DA HABITAĞ̃̃O EM MADEIRA DE PLANTIOS FLORESTAIS}

O estudo sobre a habitação em madeira com a visão de sustentabilidade requer uma abordagem que possibilite contemplar várias dimensões simultaneamente. Uma vez que o enfoque da noção de ciclo de vida é sobre questões ambientais e econômicas, outra forma de trabalho, de caráter pluridimensional é necessária.

Para tanto, o Fórum Construção (BRASIL, 2000) propõe a abordagem do ponto de vista da cadeia produtiva da construção civil, numa estrutura segmentada em produtores e prestadores de serviços, cada um com a sua estrutura própria "e de naturezas bastante distintas do ponto de vista econômico e industrial". O documento descreve três níveis hierárquicos de leitura que são de interesse para a abordagem de sustentabilidade:

- nível da empresa (capacidade empresarial - gestão de recursos, atualização tecnológica, inovação, qualidade e produtividade);

- setor em que a empresa atua (tamanho e número de empresas, estrutura de concorrência, tecnologia, organização setorial);

- nível sistêmico (sistemas econômico e social - educacional, tributário, legislação).

O enfoque nessa estrutura está nos agentes que a compõem e não o material analisado, numa abordagem genérica (Figura 6). A partir dessa estrutura básica, o documento mostra a cadeia produtiva da construção civil, composta pelas cadeias de:

- estruturas e fundações;

- vedações;

- sistemas hidráulicos;

- sistemas elétricos. 
A madeira é considerada nas primeiras duas cadeias produtivas, juntamente com outros materiais.

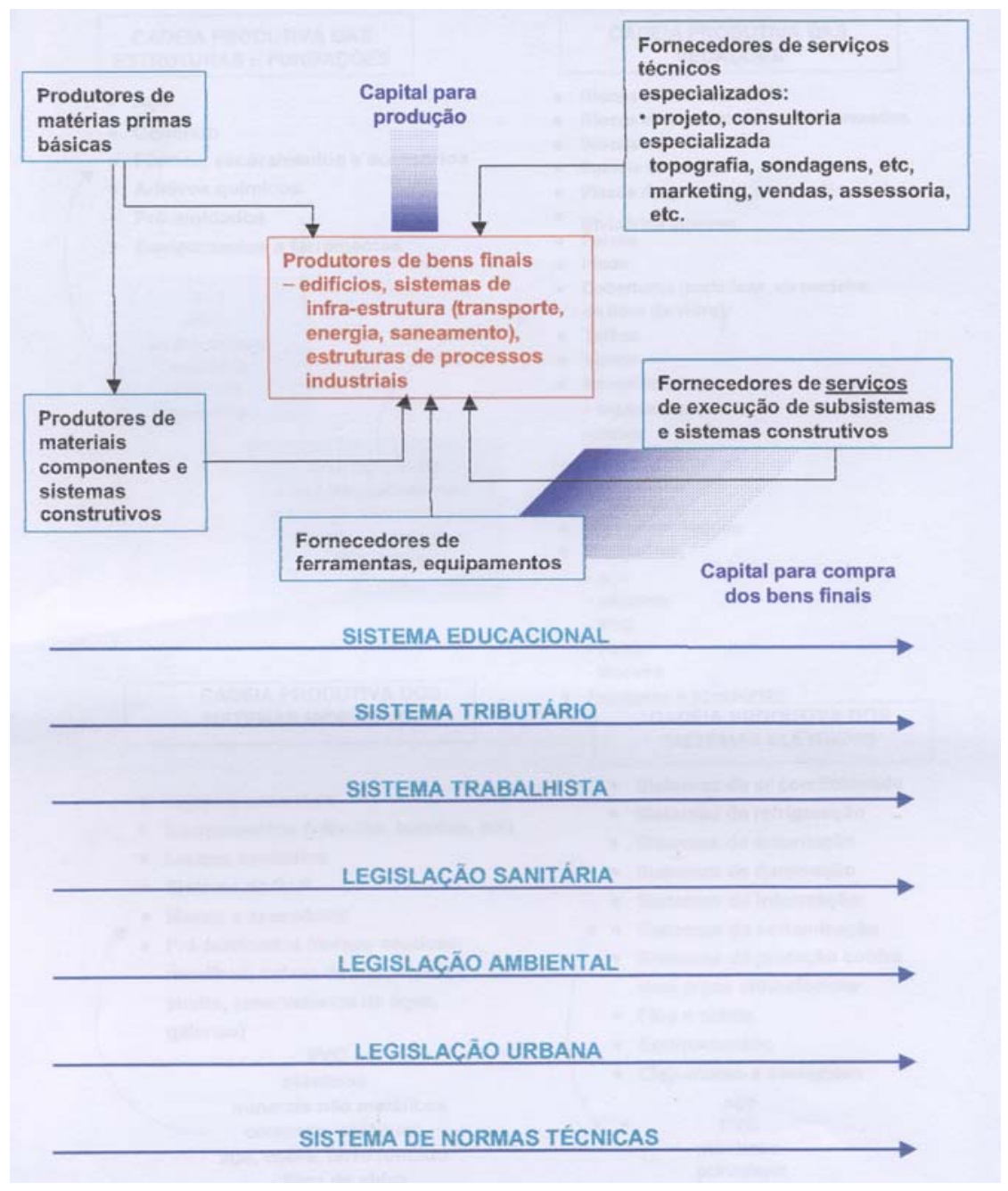

Figura 6. Estrutura básica da cadeia produtiva da construção. fonte: Brasil (2000)

Mas como o presente estudo trata da cadeia de produção de um único material, é proposto que essa segmentação seja substituída pela visão de uma única cadeia produtiva. A exploração de madeira é classificada na divisão "não-alimentar" do sistema agroindustrial como "exploração florestal", assim como móveis, papel e papelão, fumo, couro e têxteis (BATALHA, 1997). Nesse sentido, tanto esse autor como Chevalier e Toledano apud Voinson e Castagné (1988) apresentam definições similares para a cadeia produtiva. A cadeia de produção agroindustrial (CPA) tem um conjunto de três definições: 
1. "a cadeia de produção é uma sucessão de operações de transformação dissociáveis, capazes de serem separadas e ligadas entre si por um encadeamento técnico";

2. "a cadeia de produção é também um conjunto de relações comerciais e financeiras que estabelecem, entre todos os estados de transformação, um fluxo de troca, situado de montante a jusante, entre fornecedores e clientes";

3. "a cadeia de produção é um conjunto de ações econômicas que presidem a valoração dos meios de produção e asseguram a articulação das operações".

A cadeia produtiva é esquematicamente dividida em três macrossegmentos: produção de matérias primas, industrialização e comercialização; e é definida a partir da identificação de determinado produto final (cadeia produtiva da habitação em madeira, por exemplo).

Por não lidar com as etapas posteriores (uso/ manutenção e desconstrução) como faz o ciclo de vida, constitui-se numa limitação para o trabalho com a sustentabilidade. Mas, apesar disso, é um avanço para uma abordagem mais integrada que a concepção de "processo produtivo", que considera somente as sucessivas transformações da matériaprima para o produto final.

Assim possibilita a inclusão dos agentes e que outros elementos intervenientes desse setor tornem-se mais claros, como as relações comerciais, financeiras e a sua integração em um setor da economia. Batalha ainda complementa, dizendo que a visão de cadeia produtiva compreende um enfoque sistêmico e "todo sistema evolui no espaço e no tempo em função de mudanças internas e externas ao sistema". As "mudanças internas e externas" a que se refere são os fatores políticos, econômicos e financeiros, tecnológicos, socioculturais e legais ou jurídicos.

Aspecto significativo dessa visão para a sustentabilidade é a capacidade de comportar a identificação de elos dentro de uma cadeia produtiva, fortes e fracos que se prestam à “análise e formulação de políticas públicas e privadas". Nas políticas de desenvolvimento regional, Batalha aponta a utilidade da ferramenta para criar alternativas à implantação de grandes firmas numa região: "um dos trabalhos do analista seria identificar os elos da cadeia complementares às atividades já existentes na região e estimular seu desenvolvimento através de mecanismos governamentais pertinentes".

A riqueza de oportunidades criadas pela visão global do sistema com a cadeia produtiva é a análise da evolução da cadeia, mostrando as diferentes lógicas de desenvolvimento e as diferentes estratégias dos atores, a possibilidade de melhor articulá-los e entender o 
comportamento dos clientes, com seus desejos e necessidades (BATALHA, 1997). Dessa forma é possível estudar as suas interações (sob um ângulo estático e dinâmico) e os seus diferentes níveis de integração (PEREZ, VALLA apud VOINSON e CASTAGNÉ, 1988). A noção de cadeia produtiva também explicita os agentes envolvidos, ideal para um contexto em que "a conscientização de que fazem parte da mesma comunidade e que todos pertencem ao mesmo setor" é básica para o sucesso na adoção de medidas que podem necessitar de cooperação (BAKENS, 2003).

Gonçalves, com o intuito de prover uma normalização dos termos técnicos utilizados no processamento da madeira, agrupa em conjuntos as operações de transformação chamando-os de processos. Genericamente, processo é "uma seqüência de tarefas que convertem inputs em outputs" (GAVIN apud BLACK, CARLYLE e REPENNING, 2000). Gonçalves (2000) propõe a seguinte classificação:

- processo: define o tipo de trabalho a ser executado para modificar a forma ou composição da madeira utilizada como matéria-prima para produção de um determinado produto (por exemplo: usinagem, secagem);

- operação: define o trabalho de transformação de forma da madeira inserido num determinado processo (por exemplo: desdobro de toras).

Dessa forma, atividades como o projeto das edificações (processo de projeto), que não implicam numa transformação direta do produto, podem ser contempladas também na cadeia produtiva, o que era dificultado na definição de Batalha.

\subsection{As delimitações dadas pela noção de cadeia produtiva}

A operacionalização do conceito de sustentabilidade demanda, como será visto posteriormente, a definição das escalas espacial e temporal, através da criação de agendas regionais e locais, em função dos inúmeros encadeamentos entre questões da sustentabilidade e também das particularidades de cada contexto a serem consideradas na tomada de decisões.

A escala de trabalho da cadeia produtiva aproxima-se mais de uma escala regional. Para operacionalizar as questões ambientais, Van den Bergh e Nijkamp apud Munda, Nijkamp e Rietveld (1994) também se posicionam favoráveis à utilização de uma escala mediana, pela maior governabilidade, maior compreensão dos mecanismos de interação e 
retroalimentação se comparados com a abordagem em escala global, sem perder as vantagens da apreensão de problemas e capacidades específicos.

O segmento da produção de habitação e componentes para a construção civil é uma das vertentes da cadeia produtiva da madeira de plantios florestais, que lida com produtos serrados. Uma nítida diferença na área de pesquisa e desenvolvimento pode ser notada na comparação entre essa vertente com outras que tem início na mesma cadeia produtiva.

As vertentes mais organizadas apresentam estudos mais abrangentes e integradores, que consideram os elos entre os processos e entre os agentes, numa visão de cadeia produtiva. Exemplo significativo é a estruturação do setor de polpa celulósica e papel sobre a produção florestal - o seqüenciamento do genoma de árvores de eucalipto - para acelerar o crescimento das árvores e atender aos requisitos de qualidade do produto final, no Projeto ForESTs $^{18}$, conduzido pelo Projeto Genoma Agronômico e Ambiental, da FAPESP (FAPESP, s.d.). As empresas desse setor, caracteristicamente de porte grande e uniforme, são também mais autônomas para a realização de programas de pesquisas para o melhoramento das espécies plantadas (FAPESP, 2002).

Já a realidade da cadeia de produtos serrados, principalmente a da habitação, mostra um setor mais heterogêneo, com empresas de variados portes. Em 1988, Voinson e Castagné apresentaram evidências e descreveram a situação tecnológica da atividade de processamento da madeira de pinus na Região Sul do Brasil, caracterizada pela desconfiança dos técnicos, a falta de conhecimento dos usuários potenciais, a falta de dados sobre as propriedades mecânicas, dimensões reduzidas de corte - conseqüência da exploração de reflorestamentos jovens e da inadequação dos processos de corte. A clandestinidade, o índice de "mortalidade" das pequenas serrarias e marcenarias e as más condições de trabalho também são relatados.

Passados 15 anos, há indícios de que essas mesmas características ainda sejam encontradas nas empresas do setor, principalmente nas de pequeno porte. As grandes empresas verticalizadas apresentaram crescimento e uma autonomia cada vez maior. As exportações de produtos de madeira do Brasil equivalem a US\$ 4,3 bilhões (3,3\% do mercado internacional), expressivo em relação aos 10 principais produtos comercializados no mundo, mas modesto quando comparado por Tomaselli, Scheffler e Medeiros (2003) com outros países (Quadro 15). Mesmo assim, a tendência é de um crescimento acentuado

${ }^{18}$ ForESTs - Eucalyptus Genome Sequencing Project Consortium 
principalmente para produtos de madeira maciça (serrados, painéis entre outros). Somente as molduras tiveram um crescimento de 44\% na última década.

\begin{tabular}{|l|c|c|c|c|}
\hline \multicolumn{1}{|c|}{ Principais produtos } & $\begin{array}{c}\text { Mundo } \\
\text { (US\$ bilhões) }\end{array}$ & $\%$ & $\begin{array}{c}\text { Brasil } \\
\text { (US\$ bilhões) }\end{array}$ & $\%$ \\
\hline \hline Petróleo cru & 387,2 & 6,2 & 0,3 & 0,1 \\
\hline Veículos de passeio & 309,4 & 4,9 & 1,8 & 0,6 \\
\hline Componentes eletro-eletrônicos & 294,2 & 4,7 & 0,2 & 0,1 \\
\hline Equip. e acessórios de telecomunicações & 213,6 & 3,4 & 1,8 & 0,8 \\
\hline Equip. de processamento de dados & 195,1 & 3,4 & 0,3 & 0,2 \\
\hline Produtos florestais & 130,0 & 2,2 & 4,3 & 3,3 \\
\hline
\end{tabular}

Quadro 15. Comércio internacional - principais produtos e participação do Brasil. fonte: Tomaselli, Scheffler e Medeiros (2003)

Em 2002, as exportações brasileiras de produtos florestais (incluindo nativas) mostraram que os produtos de madeira maciça representaram 52\% do total, ultrapassando a celulose e papel (48\%) (Quadro 16).

\begin{tabular}{|c|r|r|}
\hline produtos & US\$ milhões & \multicolumn{1}{c|}{$\%$} \\
\hline \hline celulose e papel & 2.048 & $\mathbf{4 8}$ \\
\hline celulose & 1.161 & 27 \\
\hline papel & 887 & 21 \\
\hline produtos de madeira sólida & & \\
\hline madeira serrada & $\mathbf{2 . 2 0 6}$ & $\mathbf{5 2}$ \\
\hline tropical & 332 & 8 \\
\hline não tropical & 245 & 6 \\
\hline painéis de madeira & & \\
\hline compensado & 439 & 10 \\
\hline aglomerado & 2 & 0,1 \\
\hline chapa dura & 64 & 1,5 \\
\hline MDF & 18 & 0,4 \\
\hline PMVA & $\mathbf{4 2 4}$ & $\mathbf{1 0}$ \\
\hline móveis & $\mathbf{4 4 2}$ & $\mathbf{1 0}$ \\
\hline outros & $\mathbf{2 4 0}$ & $\mathbf{6}$ \\
\hline total & $\mathbf{4 . 2 5 4}$ & $\mathbf{1 0 0}$ \\
\hline
\end{tabular}

Quadro 16. Exportações brasileiras de produtos florestais - 2002. fonte: Tomaselli, Scheffler e Medeiros (2003) 
As diferenças entre grandes e pequenos é reforçada pela desorganização setorial que revela a continuidade de problemas de incompatibilidades técnicas (dimensões de corte, qualidade, por exemplo) nos elos da cadeia produtiva e a falta de trabalhos em parcerias (para a transferência de tecnologia, por exemplo). As pequenas empresas não têm capacidade de investimento enquanto que as grandes serrarias são geralmente detentoras de tecnologia.

Voinson e Castagné (1988) analisam que a política de incentivos fiscais é o que favoreceu o surgimento de grandes concentrações industriais na cadeia da madeira de plantios florestais (chapas e madeira serrada). Ao contrário da exploração das espécies nativas que é dispersa, a exploração do pinus é concentrada, o que gera facilidades como a exportação e a aquisição de matéria-prima. Obstáculos também são percebidos por esses autores na lógica de concentração da cadeia produtiva: os custos de transporte para produtos de baixo valor agregado (costaneiras, peças de segunda e terceira, por exemplo) e as flutuações nos preços dos produtos.

Influenciado pelo contexto e buscando o aumento no controle das operações, uma tendência à verticalização (redução dos elos) dos grandes empreendimentos (com áreas médias de plantio de 30.000 ha/ indústria) foi percebida por Voinson e Castagné, desde 1988.

Havia um comércio entre a cadeia de produtos serrados e a cadeia de trituração, baseado no diâmetro das toras (diâmetros maiores do que $20 \mathrm{~cm}$ para a cadeia de produtos serrados e toras com diâmetros entre 8 e $15 \mathrm{~cm}$ e madeira de rebrota para a cadeia de trituração), limitado pelo excedente da oferta de toras para a trituração. O estudo havia identificado uma tendência favorável à sustentabilidade, com o aumento do comércio entre as indústrias, cujo resultado possível seria a redução do preço da madeira serrada, graças à valorização das peças de pequeno diâmetro e outros subprodutos. Nessa época, o problema do desabastecimento de madeira de plantios florestais no mercado não era tão evidente e esses autores comentavam a facilidade e homogeneidade no provimento da madeira de pinus.

Essas questões modificaram-se pouco, conforme verificado na pesquisa de mestrado (YUBA, 2001). No estudo, foram identificadas praticamente as mesmas questões levantadas para a cadeia produtiva da madeira na Região Sul do Brasil em 1988. No levantamento das questões-chave foram identificadas:

- baixa velocidade de reposição florestal 
- $\quad$ perdas e má qualidade da madeira

- falta de dados sobre a cadeia produtiva

- rejeição do usuário

Baseada em levantamento bibliográfico e na realização de entrevistas a agentes da cadeia produtiva, foram constatados a ocorrência de vários problemas ambientais, tecnológicos, sociais, culturais, econômicos e políticos, tendo sido identificadas as suas possíveis causas e conseqüências, de maneira a permitir uma primeira aproximação das relações entre as diversas questões dessa cadeia produtiva (YUBA et al, 2001).

Para compreender a baixa produção de habitações em madeira no Brasil e os motivos que levam a essa situação, uma série de fatores específicos devem ser considerados, bem como suas interações. Alguns desses fatores que serão abordados ao longo do trabalho são os tecnológico - ambientais, econômicos (aumento no preço das toras, ausência de programas de financiamento para a construção de habitações em madeira), legais (códigos de obra impeditivos, influência de cadeias produtivas de outros materiais).

A partir dessas características gerais sobre a cadeia produtiva da madeira de plantios florestais, serão apresentadas a sua decomposição e a caracterização de seus processos.

\subsection{Decomposição da cadeia produtiva da habitação em madeira de plantios florestais}

A decomposição se presta a separar e delimitar os processos que compõem a cadeia produtiva da habitação em madeira de plantios florestais para facilitar a sua compreensão. Como a visualização da cadeia produtiva envolvendo aspectos técnicos, logísticos ou comerciais, é bastante complexa, "é válido que a representação seja feita seguindo o encadeamento das operações técnicas necessárias à elaboração do produto final" (BATALHA apud BATALHA, 1997).

Como a abordagem de Batalha não considera o conceito de sustentabilidade, uma adaptação se faz necessária para que a representação de cadeia produtiva comporte todas as etapas do ciclo de vida, agregando-se o uso/ manutenção e o processo de desconstrução (Figura 7). Propõe-se portanto que a decomposição seja feita da seguinte maneira:

- Processo de produção florestal, com as operações de plantio, manejo e colheita; 
- Processo de beneficiamento (de modo geral), englobando as operações de desdobro, secagem, usinagem e tratamento. $\mathrm{O}$ tratamento preservativo poderia ser visto também como um processo à parte, mas neste caso está sendo considerado como uma operação, dado que o enfoque que se objetiva dar a este trabalho é o de uma visão macro;

- Processo de construção, com as operações de pré-fabricação e montagem;

- Uso e manutenção;

- Processo de desconstrução, que também pode ser entendido como desmontagem. O propósito é possibilitar a noção de que esse processo não gera resíduos, mas estados intermediários de um mesmo produto, que pode ser reutilizado, aproveitado ou reciclado.

Gonçalves (2000) apresenta uma decomposição com tendência a incorporar algumas operações da colheita no processo de usinagem, assim como detalhando mais outras operações. Para o fim desta pesquisa, considerou-se que a decomposição dos processos poderia ser dada compreendendo a entrada e saída de produtos, estabelecendo uma escala de abordagem semelhante para todos os processos.

A madeira serrada, bem como os componentes produzidos, sejam de primeira, segunda ou terceira classe nessa cadeia produtiva são "estados intermediários da produção" da habitação, que seria, numa abordagem linear, o produto final. Com a noção de ciclo de vida, todos passam a ser estados intermediários, que "deve[m] ter estabilidade física suficiente para ser[em] comercializado[s] além, evidentemente, de possuir[em] um valor real ou potencial de mercado” (BATALHA, 1997). Isso explica os saltos entre processos, com os estados variados de "madeira serrada bruta verde, madeira serrada beneficiada seca, madeira beneficiada tratada, componente montado tratado" entre outros. 


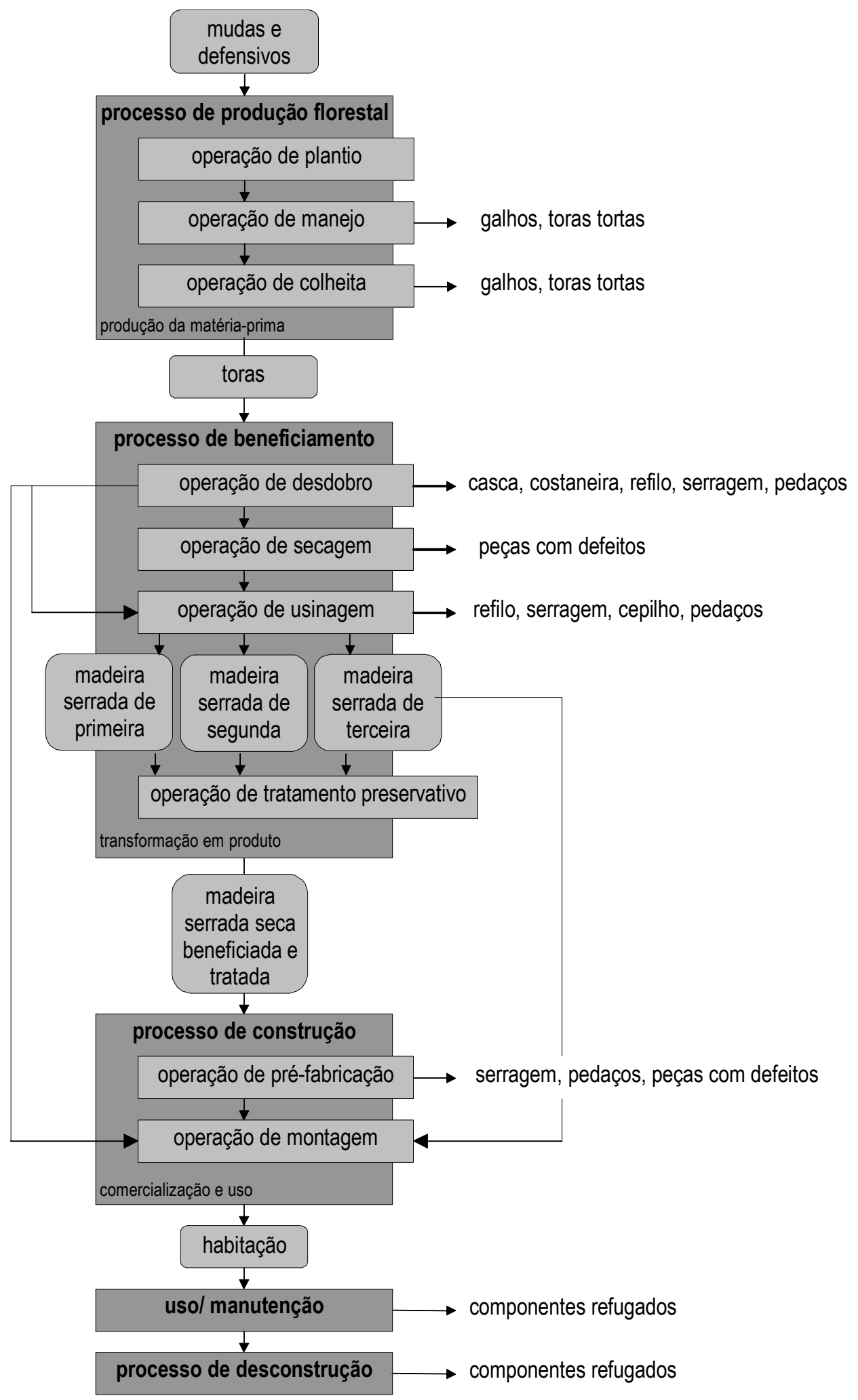

Figura 7. Processos, produtos e resíduos da cadeia produtiva da habitação em madeira de plantios florestais. fonte: adaptado de BATALHA (1997) 
Essa representação linear, entretanto, ainda carece de aprimoramentos já que não comporta a visualização de outros elementos da cadeia produtiva (relações comerciais, econômicas e políticas), a noção de ciclo presente nas discussões de sustentabilidade e nem a percepção de que a habitação é mais um estado intermediário.

\subsection{Caracterização dos processos da cadeia produtiva da habitação em madeira de plantios florestais}

De acordo com os conceitos apresentados, cada uma das operações de transformação pode ser caracterizada pelo seu fluxo, operações que o compõem, entrada de insumos (inputs), agentes, produtos e resíduos (outputs). São abordadas ainda as suas principais questões (problemas e oportunidades), buscando explorar as múltiplas dimensões da sustentabilidade.

\subsubsection{Processo de produção florestal}

O processo de produção florestal ora considerado é referente à silvicultura intensiva com as espécies exóticas mais utilizadas nos plantios florestais brasileiros (Eucalyptus spp e Pinus

$s p p)$. É uma forma de "agricultura industrializada", tendo "natureza, localização, inputs, níveis de tratamento, outputs e padrões de distribuição de uma indústria". O objetivo principal dos plantios florestais como culturas intensivas "é otimizar os efeitos impostos pelo homem para atingir determinadas metas de produção", aumentando a produtividade por unidade de área e/ou obtendo uma redução da área destinada para plantio no menor tempo possível (EDGAR, 1978, p.377).

$\mathrm{Na}$ cadeia produtiva da habitação em madeira de plantios florestais, esse processo está sendo considerado como o inicial, apesar da importância das cadeias de produção de seus insumos (mudas, defensivos agrícolas, ferramentas, equipamentos e combustível), que são considerados por Batalha como "indústrias de apoio".

O processo de produção florestal envolve as operações de cultura (seleção de espécies), preparação do solo (fertilização, controle de ervas daninhas, controle de pragas e insetos), plantio, manejo, colheita e medidas de regeneração (EDGAR, 1978).

O manejo é definido como "um conjunto de tratamentos aplicados a uma floresta durante uma rotação" (OPIE, CURTIN e INCOLL, 1978, p. 180) para o controle das variáveis de 
interesse para a produção de madeira serrada - densidade, diâmetro, retidão, comprimento e presença de nós. As atividades relacionadas ao manejo são a adubação, controle de ervas daninhas e pragas, desbastes, desramas e duração da rotação. A realização dessas atividades interfere no rendimento por tora e na produtividade de toras aptas para uso por hectare.

A operação de colheita consiste no "seccionamento da árvore em sua porção inferior através de ferramentas manuais ou automáticas, com ou sem motorização, seguido do desgalhamento da tora e corte em dimensões de comprimento padrão, a fim de viabilizar seu transporte ou facilitar o manuseio e movimentação das peças” (GONÇALVES, 2000, p.100).

A colheita pode ser realizada mecanicamente com o uso de veículos especiais ou com equipamentos portáteis (KERRUISH, 1978). “Como ferramentas manuais são empregados machados ou serrotes [...],já as máquinas motorizadas, manuais ou automáticas, em sua grande maioria utilizam correntes dentadas como ferramenta de corte" (GONÇALVES, 2000, p.100).

Quando o processo é mecanizado, os equipamentos utilizados para a colheita de eucalipto são diferentes dos utilizados para o pinus. A forma da árvore, a densidade básica e verde e a estrutura da casca são as variáveis que determinam tais diferenças.

A sustentabilidade ambiental discute os efeitos da extração (extensão, intensidade e duração), principalmente a perturbação causada no solo, afetando a qualidade dos corpos d'água superficiais e subterrâneos. Por isso, Lima (1993) recomenda na operação, a conservação das folhas, ramos finos e casca (componentes ricos em nutrientes) no campo e a consideração do potencial de erosão local.

O impacto da colheita também agrava o problema da reduzida diversidade da fauna e flora das monoculturas, havendo mecanismos a serem implantados no entorno para minimizar os efeitos negativos. Edgar (1978) ainda comenta que a colheita pode contribuir para o aumento das reservas de água com a redução das perdas por transpiração, a ser verificada, pela existência de outros fatores que interferem nessa conclusão. $\mathrm{Na}$ dimensão social, a questão citada é o atendimento aos requisitos de segurança dos trabalhadores, presente nos princípios de certificação florestal do FSC.

Os subprodutos desse processo são os galhos das desramas e as toras não aptas (tortas ou defeituosas) dos desbastes e peças de pequeno diâmetro, mas com uma tendência cada vez 
maior de redução, através dos melhoramentos dos plantios e definições de mercados compradores, sejam na mesma cadeia produtiva ou em outras.

Os questionamentos sobre a sustentabilidade dos plantios florestais também têm ganhado maior representatividade nas discussões do setor, visto o crescimento da importância dos programas de certificação. Envolve várias questões de múltiplas dimensões, em diferentes escalas espaciais (o talhão, a floresta, a região, a cidade, o estado e o país) e temporais (ano, década, século). No estudo realizado por Edgar, são assumidas de antemão três escalas geográficas utilizadas para analisar as implicações sociais e ambientais da silvicultura intensiva: o talhão - (área onde as práticas são diretamente aplicadas), a floresta (a unidade de manejo do qual a área é parte), e a área além da floresta (a região social que pode ser afetada pelas operações) (EDGAR, 1978).

Cada uma das questões pode gerar impactos positivos ou negativos, que podem ser analisados com o uso de indicadores e são classificáveis de acordo com as dimensões ambiental, econômica, social, política, cultural, além de outras dimensões. As principais em discussão são:

3.3.1.1. Os impactos ambientais (no solo, recursos hídricos, fauna, flora e clima) causados pelas espécies e pela atividade de silvicultura intensiva

Na escala do talhão, tanto Edgar (1978) quanto Lima (1993) tratam dos seguintes impactos:

- características físicas e químicas do solo local: a redução da porosidade do terreno pela sua compactação, que por sua vez é causada pelas operações florestais intensivas; os incêndios que removem a camada de folhas e galhos da superfície; o escoamento superficial, erosão e perda de estabilidade de encostas e desbarrancamentos, causados pela reduzida capacidade de armazenamento e infiltração; a redução da fertilidade do solo pelo transporte de nutrientes para as árvores, por perdas associadas aos distúrbios do solo e volatilização (nitrogênio, enxofre e fósforo). Para esses impactos ambientais, é recomendada a conservação do piso florestal e da faixa de proteção florestal de 20 metros de largura ao longo de toda a rede de drenagem. Também são recomendados: o uso mais eficiente da fertilização mineral, a verificação de viabilidade de utilização de sistemas agroflorestais ou agrosilvopastoris durante a fase de crescimento inicial da plantação, a utilização de espécies leguminosas em consorciação a fim de aumentar a 
fixação biológica de nitrogênio e acelerar a mineralização da serapilheira e por fim a seleção adequada de espécies e clones em relação à eficiência nutritiva;

- hidrologia da floresta: as perturbações características das culturas intensivas (distúrbios no solo, queimadas e a decomposição acelerada de materiais orgânicos) provocam efeitos combinados no solo e na hidrologia. Tais atividades portanto podem ampliar os efeitos sobre a qualidade da água;

- fauna e flora: o direcionamento para a produção madeireira reduz a diversidade de espécies e altera a estrutura da vegetação local impactando as cadeias tróficas, os abrigos e ninhos. Para minimizar tal situação, pesquisas dizem que esse impacto poderia ser reduzido em longo prazo se as populações fossem mantidas nos arredores, aumentando o número de habitats ao longo da área (áreas abertas, áreas de borda, reservas naturais, áreas encharcadas, açudes; distribuição estratégica de reservas naturais ao longo da área, preferencialmente interligadas por corredores de vegetação natural), favorecendo a diversidade etária das plantações e repensando a utilização de fertilizantes minerais e herbicidas, uma vez que podem afetar a fauna e os microorganismos do solo.

Numa escala mais ampliada, que abrange a floresta como um todo, são relatados:

- as trilhas mal projetadas que contribuem para o escoamento superficial, erosão e sedimentação, com prejuízos à qualidade da água. O correto traçado de acordo com a topografia e controle da erosão ainda são as melhores soluções;

- redução da diversidade do banco genético vegetal, da vida selvagem e conseqüente desenvolvimento de doenças e pragas: tal redução, causada pela seleção de fenótipos desejáveis para a produção de madeira, interfere nos processos de seleção natural. Efeito similar pode ocorrer com a fauna. Animais terrestres que dependem de grandes áreas como habitat podem ser reduzidos em quantidade assim como as aves pela redução da diversidade estrutural da vegetação. As trilhas podem se tornar barreiras para a diversidade genética, cuja redução predispõe as monoculturas a ataques de pragas e doenças, potencialmente espalhadas pela uniformidade da floresta e pela existência de atividades nos seu interior. As barreiras podem ser minimizadas com a criação de corredores ecológicos que os animais podem utilizar durante as práticas de manejo no local. 
O conhecimento do funcionamento das microbacias (inputs, armazenamentos e outputs) e a manutenção da integridade do solo, da produtividade do sítio e da manutenção da diversidade biológica, cujas ações foram citadas acima, seriam os meios de proporcionar uma visão sistêmica dos plantios florestais, proposta por Lima. Isso quer dizer que a aplicação das estratégias de cunho ambiental depende de uma outra em especial, a capacitação e conscientização dos produtores florestais, dentre várias outras.

Indiferentemente da espécie utilizada, o problema dos impactos ambientais é atribuído à intensidade da silvicultura. Lima, num enfoque que busca reduzir a pressão sobre o gênero eucalipto, concorda que a monocultura extensiva de eucalipto, ou de qualquer outra espécie de planta pode resultar na diminuição de recursos para a existência de uma fauna variada havendo para isso, práticas adequadas de manejo a serem adotadas. Há necessidade de adaptação da silvicultura intensiva "de tal maneira que ela cause um mínimo de efeito ao funcionamento e às propriedades físicas, químicas, biológicas e hidrológicas do ecossistema” (LIMA, 1993, p.212). A diversidade e intensidade dos regimes de manejo dependerão das variações de mercado, locais, custos e preços (FERGUSON e DARGAVEL, 1978). Isso quer dizer que, em virtude do aumento da demanda por toras, são necessários mais plantios com regimes de manejo menos intensivos, para haver menos perturbações no solo. A relação entre as dimensões ambiental e econômica, assim como outras, serão abordadas no Capítulo 4.

Mas em relação ao gênero, o autor apresenta em sua análise trabalhos sobre florestas naturais de eucalipto, que permitem "um referencial adequado para comparação" e refuta a atribuição dos impactos ambientais ao gênero como um todo, concluindo que a maioria das críticas ao eucalipto "não tem fundamento" (LIMA, 1993, p.18). Observa que na maior parte das afirmações de outros autores sobre tais impactos, apenas parte das variáveis locais e regionais é considerada nas abordagens estudadas, havendo necessidade de estudos mais completos.

Uma das hipóteses levantadas sobre a resistência ao eucalipto é a influência da frustração de experiências mal sucedidas nos plantios florestais iniciais (POORE e FRIES apud LIMA, 1993) pela escolha de espécies não adequadas para as condições locais (má adaptação, efeitos ecológicos não aceitáveis) e para os propósitos de uso (produção abaixo das expectativas) (FLORENCE; ELDRIDGE e CROMER apud LIMA, 1993, p.31).

É relatado que em ambientes de florestas naturais de eucalipto, os resultados obtidos são semelhantes aos de florestas de outras espécies. Essa afirmação vale para a qualidade da 
água que drena bacias hidrográficas, o regime da água do solo e da água subterrânea (flutuação e recarga do lençol freático), a ação de florestas em larga escala sobre o clima, as perdas evaporativas por interceptação da água da chuva pelas plantações florestais, o possível ressecamento do solo, sobre o consumo total de água e as variações decorrentes do plantio e da colheita na bacia, a demanda de nutrientes que é relativamente alta, tanto quanto outras espécies florestais de rápido crescimento, mas muito menor do que a demanda normalmente apresentada por culturas agrícolas.

Para a avaliação dos efeitos de ressecamento dos corpos d'água e alterações no clima, outras variáveis devem ser consideradas: o aumento da população, intensidade de uso do solo, presença de rebanho bovino (e conseqüente sobrepastoreio e compactação do solo) e uso de fogo (PEREIRA apud LIMA, 1993).

Concluiu-se que enquanto os plantios de eucalipto não são perturbados, estes podem contribuir para o controle do escoamento superficial e as perdas de solo e nutrientes conseqüentes da erosão. Numa avaliação em longo prazo, até efeitos positivos foram notados sobre as condições do solo (propriedades químicas, físicas e microbiológicas).

Entretanto, a realidade dos plantios florestais é de constantes perturbações, seja durante as atividades de manejo, seja na colheita, e por isso, os impactos gerados necessitam ser considerados nas análises.

No sentido de propor medidas práticas de uso do solo mais modernas, o que significa a introdução de conceitos de manejo sistêmico ou integrado "implica a existência de uma ligação mútua e interativa entre a floresta e todos os demais elementos do ecossistema, incluindo o fluxo de energia e a ciclagem da água e dos nutrientes" (PERRY et al, BEHAN, DUERR apud LIMA, 1993). O manejo florestal integrado significa então o entendimento dessas inter-relações e interações e a busca de práticas que visem minimizar os impactos ao funcionamento do ecossistema buscando a manutenção do funcionamento harmônico do ecossistema.

Rodigheri (1997) e Lima analisam os benefícios da implantação de sistemas agroflorestais ou agrosilvopastoris. "Sistema agroflorestal pode ser definido como uma modalidade de uso integrado da terra para fins de produção florestal, agrícola e pecuária”. Essa forma de produção é considerada alternativa menos impactante ao meio ambiente além de ter vantagens do ponto de vista social. Ecologicamente, "a coexistência de mais de uma espécie numa mesma área pode ser justificada em termos de ecologia de comunidades: desde que as duas espécies ocupem nichos diferentes, de tal forma que seja mínimo o nível 
de interferência, então as duas espécies podem coexistir" (VANDERMEER apud LIMA, 1993, p.183).

Focalizando a rentabilidade econômica, obtenção de indicadores de custo e de produtividade, Rodigheri estabelece comparações entre plantios solteiros de erva-mate, eucalipto e pinus; sistemas agroflorestais com erva-mate, eucalipto e pinus com o cultivo intercalado de feijão e milho; e as culturas de feijão, milho, soja e trigo. O autor conclui que para a região estudada (Paraná, Santa Catarina e Rio Grande do Sul) todas as formas de produção são economicamente viáveis, com maior expressividade para os cultivos florestais solteiros e agroflorestais. Foram observados ainda a redução da utilização de agrotóxicos e vantagens como a produção de madeira e alimentos, racionalização do uso do solo e mãode-obra, redução dos riscos técnicos de produção e aumento do emprego e renda das propriedades.

Lima relata ainda as vantagens do menor nível de perturbação do sítio, a condição de proteção mais adequada pelas copas das árvores, a tendência da ciclagem de nutrientes ser mais rápida, o melhor aproveitamento dos nutrientes da fertilização mineral que seriam normalmente perdidos num sistema convencional de monocultura pelas culturas intercalares, efeito neutralizante entre uma espécie de demanda alta de nutrientes e a capacidade maior de enriquecimento orgânico do solo apresentado pela outra espécie consorciada.

Lindenmayer apóia a mímese de regimes de distúrbios naturais que sirvam de modelo para sistemas de gerenciamento conservativo de áreas de produção de madeira. (LINDENMAYER, 1995). Uma base conservativa pra gerenciamento florestal requer mais do que a criação de uma série de gerações de reposição florestal, o estabelecimento de mais e maiores áreas de florestas antigas e/ou modificações nos regimes de corte raso para melhor permitir o desenvolvimento da vida selvagem que são sensíveis aos impactos da colheita de madeira.

Os processos de certificação teriam um papel importante na definição e monitoramento de melhores práticas na produção florestal. A certificação nasceu como uma alternativa aos boicotes de produtos tropicais, institucionalizando-se cada vez com a participação de ONGs e órgãos do governo e sendo utilizadas por um número cada vez maior de países. Além dos sistemas que se baseiam no FSC e ISO, um novo sistema está sendo elaborado para o contexto nacional, o CERFLOR-ABNT, cujas diferenças estão apontadas no Quadro 17. 


\begin{tabular}{|c|c|c|}
\hline $\begin{array}{c}\text { Principais } \\
\text { características }\end{array}$ & FSC (operado por IMAFLORA, SCS e SGS) & CERFLOR (operado pela ABNT) \\
\hline $\begin{array}{l}\text { Credenciadora } \\
\text { internacional }\end{array}$ & Forest Stewardship Council (FSC) & $\begin{array}{l}\text { Não há, pretende vincular-se ao sistema de mútuo } \\
\text { reconhecimento }\end{array}$ \\
\hline Área de atuação & Global & Brasil \\
\hline Data de inicio & 1993 & $\begin{array}{l}\text { 1993, ainda em conclusão, inicio previsto para } \\
\text { março de } 2002\end{array}$ \\
\hline Nivel de mercado & Intemacional & Regional/Nacional \\
\hline Tipo de produtor & Empresas exportadoras de base florestal & Ainda não está operando \\
\hline Gerenciamento & $\begin{array}{l}03 \text { câmaras (ambiental, social e econômica) } \\
\text { com predominio de ONGs socioambientais }\end{array}$ & $\begin{array}{l}\text { Predominio de instituições governamentais, } \\
\text { téenico-cientificas e do setor empresarial }\end{array}$ \\
\hline Nivel de performance & $\begin{array}{l}\text { Pré-definido pelo FSC, baseado em critérios e } \\
\text { padrões externos à empresa certificada }\end{array}$ & $\begin{array}{l}\text { Não está operando, mas deve sofrer influência do } \\
\text { Sistema de Melhoria Continua }\end{array}$ \\
\hline Area total certificada & 1.049 .510 hectares & - \\
\hline Area média certificada & 58.034 hectares & - \\
\hline $\begin{array}{l}\mathrm{N}^{0} \text { de empresas } \\
\text { certificadas }\end{array}$ & 18 unidades florestais e 95 cadeias de custódia & - \\
\hline Menor área certificada & 1.481 hectares & - \\
\hline Principios & 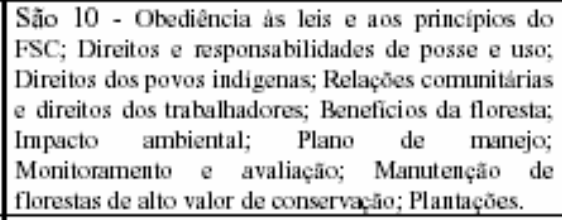 & $\begin{array}{l}\text { São } 5 \text { - Cumprimento da lei; Busca da sustentabilidade } \\
\text { dos recursos florestais e racionalidade no uso a aurto, } \\
\text { médio e longo prazos; Zelo pela diversidade biobgica; } \\
\text { Respeito ass aguas, ao solo e ao ar; Desenvolvimento } \\
\text { anbiental, social e econômico das regiōes em que se } \\
\text { insere a atividade florestal }\end{array}$ \\
\hline $\begin{array}{l}\text { Principal motivo para } \\
\text { certificar }\end{array}$ & Exigência de clientes & - \\
\hline $\begin{array}{l}\text { Aspectos negativos } \\
\text { levantados }\end{array}$ & $\begin{array}{l}\text { Alto custo } \\
\text { Niveis de performance definidos por terceiros } \\
\text { Exposição da empresa } \\
\text { Interferência em gerência e operações internas } \\
\text { Alta exigência de direitos sociais (avaliado } \\
\text { como a maior dificuldade empresarial) } \\
\text { Muito peso para a floresta na cadeia de } \\
\text { custódia } \\
\text { Dependência da pequena oferta de madeira } \\
\text { certificada para certificar a cadeia de custódia }\end{array}$ & $\begin{array}{l}\text { Falta de credenciamento internacional } \\
\text { Interface confusa entre sistemas de gestão } \\
\text { ambiental e certificação florestal } \\
\text { Menor peso para direitos sociais e preservação } \\
\text { cultural } \\
\text { Não é um programa operacional } \\
\text { Pouca transparência } \\
\text { Menor alcance de mercado } \\
\text { Menor participação de ONGs socioambientais } \\
\text { Maior participação do setor empresarial }\end{array}$ \\
\hline $\begin{array}{l}\text { Aspectos positivos } \\
\text { levantados }\end{array}$ & $\begin{array}{l}\text { Implementação e melhoria do manejo florestal } \\
\text { Capacitação dos trabalhadores florestais } \\
\text { Aumento da qualidade e produtividade } \\
\text { Alta exigência e seriedade das certificadoras } \\
\text { Maior integração nas empresas } \\
\text { Imagem "verde" da empresa } \\
\text { Acesso a novos mercados e expansão de } \\
\text { antigos } \\
\text { Diferenciação da empresa e seus produtos } \\
\text { Melhora a competitividade } \\
\text { Garantia dos mercados existentes } \\
\text { Acesso a financiamentos públicos e privados, } \\
\text { nacionais e internacionais } \\
\text { Melhor monitoramento interno } \\
\text { Sobre-preço na madeira certificada } \\
\text { Mudança em padrões de comércio e } \\
\text { concorrência }\end{array}$ & $\begin{array}{l}\text { Alternativa à certificação florestal via FSC } \\
\text { Inserido no Sistema Brasileiro de Certificação } \\
\text { Não submissão da silvicultura brasileira a normas } \\
\text { extemas (crítica ao FSC) } \\
\text { Maior competitividade } \\
\text { Evita "radicalismos" sócioambientais } \\
\text { Formação de especialistas nacionais } \\
\text { Estímulo a organismos de certificação nacionais } \\
\text { Credibilidade e aceitação internacional (ISO) } \\
\text { Alinhado com Processo Tarapoto e ITTO. } \\
\text { Fácil compatibilização com o sistema ISO. } \\
\text { Facilidade de ingressar em um sistema de mútuo } \\
\text { reconhecimento, por ser conduzido pelo Sistema } \\
\text { Nacional de Normalização }\end{array}$ \\
\hline
\end{tabular}

fonte: entrevistas e pesquisa de dados em FSC (2002), Garlipp e Maffeis (2001) e ABNT (2001).

OBS: essas informações não representam a opinião dos autores. São os resumos de avaliações das referidas fontes.

Quadro 17. Características dos sistemas de certificação florestal, operantes no Brasil. fonte: Bulhões e Souza (2002)

Ressalta-se que os dados contidos nesse quadro representam a visão dos produtores florestais e não a dos trabalhadores envolvidos na produção, havendo por isso a necessidade de rever os impactos ditos "positivos" e "negativos". 
Com a certificação de manejo e a certificação de cadeia de custódia, o FSC ${ }^{19}$ certificou 1,05 milhão de hectares de florestas (distribuídas em 18 empresas) e 95 empresas em cadeia de custódia no Brasil, com crescimento relativo de 249\% para área florestal e 300\% para o número de empresas em dois anos e meio (WWF ${ }^{20}$ e FSC apud Bulhões e Souza, 2002).

A cadeia de custódia é definida pelo FSC como o "canal pelo qual os produtos são distribuídos desde sua origem na floresta até o seu usuário". Kiekens acrescenta ainda que é um procedimento pelo qual os produtos florestais são certificados e autorizados a utilizar a marca registrada, seguindo um procedimento de monitoramento, através de inventário. A certificação de cadeia de custódia também é criticada (BERG apud KIEKENS, 2000), principalmente no setor de papel, que obtém as vantagens da certificação utilizando uma porcentagem mínima $(20 \%)$ de polpa certificada.

A dificuldade de obtenção da certificação por pequenos produtores sempre foi questão em debate nesses processos, considerados "caros e burocráticos". Isso faz com que somente as empresas detentoras de grandes áreas florestais tenham capacidade de se estruturar para atingir os padrões exigidos. Então, o que antes era visto como oportunidade para a entrada de pequenos empresários nas exportações, tornou-se praticamente uma barreira, privilegiando somente as maiores empresas.

“O discurso da certificação floresta prega que ela auxiliará comunidades locais, indígenas, seringueiros e outras minorias no acesso ao mercado. Mas, segundo os dados estudados, este processo não está ocorrendo ou está em fase inicial. Há apenas grandes áreas certificadas, pertencentes a empresas. Não há nenhum grupo ou associação de pequenos produtores conseguindo acessar este mercado (BULHÕES e SOUZA, 2002)”.

Comentam os autores que, em virtude desse cenário, o IMAFLORA ${ }^{21}$ está conduzindo os quatro primeiros processos de certificação comunitária, "entretanto ainda não há, efetivamente, pequenas áreas certificadas".

Além disso, o sistema do FSC é criticado pelas empresas por ser "ecocêntrico" (focalizado nas questões ambientais mais do que nas econômicas) e por ser inflexível na questão da utilização de organismos geneticamente modificados. De outro lado, os órgãos ambientais criticam a excessiva flexibilidade do sistema ao permitir a existência de extensas "monoculturas insustentáveis que sequer poderiam ser chamadas de florestas" (WRM apud BULHÕES e SOUZA, 2002).

\footnotetext{
${ }^{19}$ FSC - Forest Stewardship Council

${ }^{20}$ WWF - World Wildlife Fund

${ }^{21}$ IMAFLORA - Instituto de Manejo e Certificação Florestal Agrícola
} 
Kiekens observa que nas grandes indústrias, os benefícios conseguidos foram sobre a capacidade de gerenciamento através do melhoramento dos sistemas de gerenciamento, a indução da redução de custos e aprimoramento da situação da empresa (BASS e SIMULA apud KIEKENS, 2000). O autor ainda comenta que nas florestas não industriais a educação dos proprietários de terras é provavelmente a chave para explicar o melhoramento das práticas florestas, e não a certificação em si.

As diferenças estão arraigadas em cada sistema e tendem a sobressair cada vez mais, nos embates que afetam a comercialização de produtos, fato que se considera positivo para a constante remodelação desses sistemas, até que sejam atendidos os anseios de pequenos e grandes produtores e também dos órgãos ambientais.

3.3.1.2. A geração de oportunidades de emprego local e regional versus a crescente concentração fundiária

A implantação de plantios florestais nem sempre reflete em efeitos sócio-econômicos positivos (em todas as escalas), o que depende da forma como foram concebidos.

O mais evidente é o problema da concentração de renda e desemprego originado durante a vigência do programa de incentivos fiscais. É criticado o modelo de incorporação de terras, que resulta na concentração de latifúndios e na redução gradativa da oferta de empregos à medida que os plantios crescem. O efeito desse cenário é um reforço ao êxodo rural e o declínio do padrão de vida regional (KENGEN apud LIMA, 1993, p.3031).

Com efeito, atualmente no Estado de São Paulo, os maiores detentores das áreas de plantio florestal são as empresas do setor de papel e celulose, chapas e matéria-prima para energia, com 45,1\% das áreas, apresentado na Tabela 1. Os outros detentores identificados são reflorestadoras, pequenos reflorestadores (produtores de matéria-prima para diferentes finalidades - processamento mecânico, material energético, celulose, chapas, construções rurais e energia) e entidades governamentais (IBAMA e Instituto Florestal). 
Tabela 1. Detentores das áreas de reflorestamento no Estado de São Paulo.

\begin{tabular}{|c|c|c|c|c|c|c|}
\hline \multirow{2}{*}{ categorias } & \multicolumn{6}{|c|}{ gênero (área em ha) } \\
\hline & eucalipto & $\%$ & pinus & $\%$ & total & $\%$ \\
\hline empresas & 300.089 & 49,1 & 46.960 & 29,6 & 347.049 & 45,1 \\
\hline reflorestadoras & 88.922 & 14,5 & 48.490 & 30,5 & 137.412 & 17,8 \\
\hline governamentais & 16.220 & 2,7 & 25.228 & 15,9 & 41.448 & 5,4 \\
\hline não identificadas & 206.286 & 33,7 & 37.815 & 24 & 244.101 & 31,7 \\
\hline total & 611.517 & 79,4 & 158.494 & 20,6 & 770.010 & 100 \\
\hline
\end{tabular}

Se mantida essa distribuição, a representatividade das florestas governamentais ou públicas diminuirá, estando o mercado de toras cada vez mais sujeito às práticas comerciais das empresas do setor, fragilizando a sustentabilidade da cadeia produtiva na sua base (fornecimento de matéria-prima).

$\mathrm{Na}$ caracterização dos plantios feita pelo Inventário Florestal percebe-se a ausência de informações (espécie, manejo e idade) sobre os plantios pertencentes a pequenos proprietários, englobado num conjunto de número significativo - 33,7\% da área de eucalipto e $24 \%$ da área de pinus, chegando ou superando em alguns itens a 50\% dos casos, o que dificulta a apreensão das reais características dos plantios. Entre as áreas de plantio cujos detentores e informações não foram identificados (13.078 fragmentos), 72\% são áreas de até 10 hectares. A Figura 8 mostra a significativa representatividade desses fragmentos, que incluem os plantios pertencentes a pequenos proprietários. 


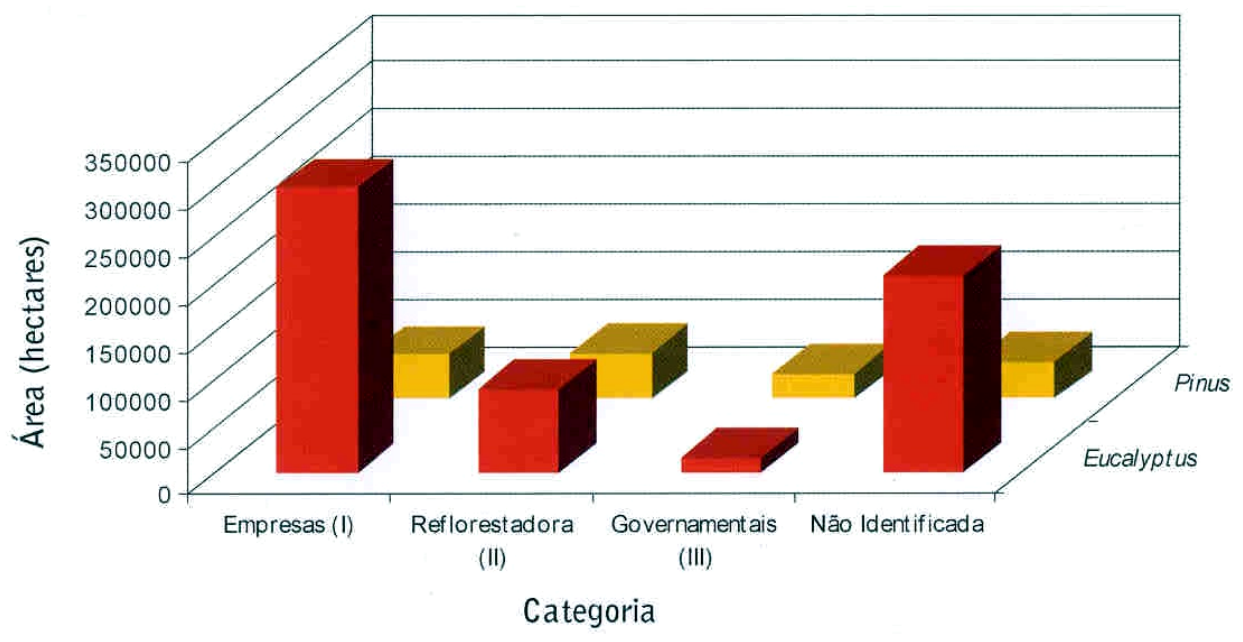

Figura 8. Detentores das áreas de reflorestamento do Estado de São Paulo. fonte: Kronka (2002)

A Região Sudoeste do Estado de São Paulo concentra 38\% das florestas de eucalipto e $58,5 \%$ das florestas de pinus, representando quase a metade de todas as florestas plantadas do Estado. O rol dos detentores dos plantios florestais na Região Sudoeste do Estado de São Paulo também apresenta as empresas como os maiores proprietários, conforme apresentado na Tabela 2.

Tabela 2. Detentores das áreas de plantios florestais na Região Administrativa de Sorocaba.

\begin{tabular}{|c|c|c|c|c|c|c|}
\hline \multirow{2}{*}{ categorias } & \multicolumn{6}{|c|}{ gênero (área em ha) } \\
\hline & eucalipto & $\%$ & pinus & $\%$ & total & $\%$ \\
\hline empresas & 135.678 & 58,1 & 31.120 & 33,5 & 166.798 & 51,2 \\
\hline reflorestadoras & 46.877 & 20,1 & 34.707 & 37,5 & 81.584 & 25 \\
\hline governamentais & 3.148 & 1,3 & 14.524 & 15,7 & 17.672 & 5,4 \\
\hline não identificadas & 47.704 & 20,5 & 12.313 & 13,3 & 60.017 & 18,4 \\
\hline total & 233.406 & 71,6 & 92.664 & 28,4 & 326.070 & 100 \\
\hline
\end{tabular}

Fonte: Kronka (2002).

Nessa região, para cada hectare de pequenas propriedades, 2,78 hectares pertencem a uma grande empresa de domínio privado, enquanto que no total do Estado essa relação corresponde à metade (1,42 hectares). Esse valor ainda é superestimado porque considera que o total de fragmentos "não identificados" seja de pequenos proprietários. 


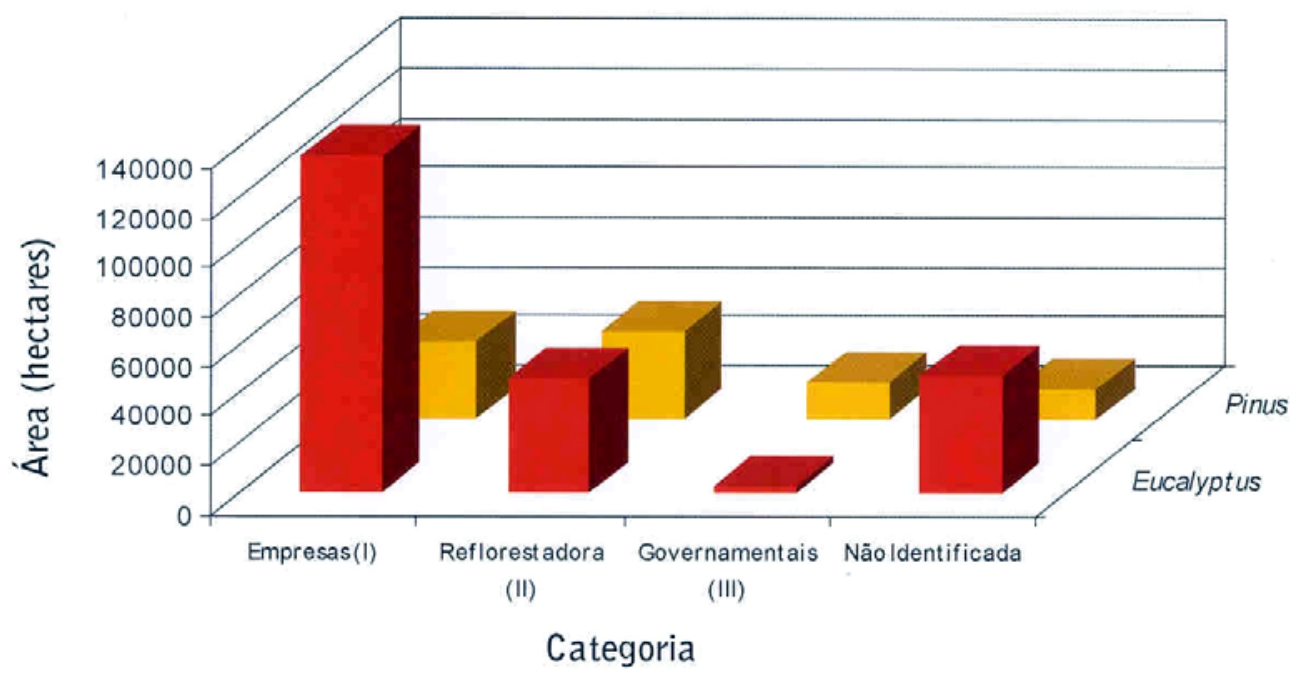

Figura 9. Detentores das áreas de reflorestamento da Região Administrativa de Sorocaba. fonte: Kronka (2002)

A discussão sobre a sustentabilidade econômica das florestas plantadas deve tratar da relação custo-benefício de forma mais flexível, reconsiderando a associação direta entre produtividade e lucratividade (EDGAR, 1978) evidentemente presente nos plantios privados. Por isso a importância da implantação e manutenção de florestas públicas e da dispersão das florestas em pequenas propriedades.

Dados sobre o município de Itararé, que está na região abrangida pela maior população florestal plantada do Estado, explicitam que a relação entre a presença de grandes empresas florestais e bem estar da população precisa ser mais bem analisada. O SEBRAE/SP reuniu informações sobre o município que caracterizam o seu estado de pobreza. $\mathrm{Na}$ educação, o município, apesar de contar com ensino básico ao universitário, apresenta taxa de analfabetismo de 15,21\%, maior que a do total do Estado. Há problemas para a manutenção da população jovem no município pela ausência de ensino público técnico e de nível superior. A população de Itararé em 1997 era de aproximadamente 45.500 habitantes e desde então a taxa de crescimento vem declinando a cada ano (SEBRAE/SP, 2000).

A Fundação SEADE (SEADE, 2004) mediu em 2000 o índice de responsabilidade social, nas dimensões riqueza, longevidade e escolaridade cujos dados são apresentados no Quadro 18. 


\begin{tabular}{|l|c|c|c|}
\hline & Estado de SP & Reg. Adm. Sorocaba & Mun. Itararé \\
\hline \hline riqueza & 60 & 49 & 33 \\
\hline longevidade & 65 & 64 & 48 \\
\hline escolaridade & 87 & 81 & 75 \\
\hline
\end{tabular}

Quadro 18. Índice de responsabilidade social do Estado de São Paulo, Região administrativa de Sorocaba e Município de Itararé

fonte: Fundação SEADE, 2004

A remuneração do setor agropecuário é a menor em Itararé em 1997 e 1998 e a média das remunerações é inferior à do Estado em todos os níveis de instrução. Quanto ao total de remunerações, percebe-se que em Itararé este total (3,23 SM) é menor do que a metade comparativamente ao do Estado de São Paulo (6,68 SM) (SEADE, 2003). Apesar de incompletos, esses dados dão indício de que não se pode generalizar a afirmação de geração de empregos intensivos e duradouros.

Para reforçar esse cenário, com relação ao número de estabelecimentos (lotes agrários) e área por grupo de área total, nota-se que de 1985 para 1996 houve uma maior distribuição dos estabelecimentos entre as várias faixas de agrupamentos por área. Houve também uma queda no número de estabelecimentos entre esses anos passando de 1.794 em 1985 para 525 estabelecimentos em 1996 e quanto à área total, ela passou de 100.705 ha para 90.445,77 ha, de 1985 a 1996, respectivamente (SEADE, 2003).

3.3.1.3. Possíveis causas para a redução da oferta de madeira de plantios florestais no mercado

Além das características inerentes à madeira, aspectos naturais presentes em todas as regiões do país tornam-se oportunidades para o desenvolvimento de novos maciços florestais (LIMA, 1993):

- condições naturais favoráveis para a produção de florestas;

- disponibilidade de território para plantios florestais;

- alta produtividade, comparada com países de clima temperado. Se comparado com as florestas naturais, a cultura intensiva ocupa menos espaço para atender à mesma meta de produção de madeira, além de apresentar economia direta nos custos de produção; 
- menor custo de geração de postos de trabalho (US\$ 600,00 no campo e US\$17.000,00 no setor industrial);

- distribuição estratégica das florestas para utilização como cerca viva, quebra vento, sombra, conservação do solo e da água, produção de madeira e de lenha, proteção do gado durante as intempéries (PAINE, OLIVEIRA et al, CORSI apud LIMA, 1993).

Vantagens competitivas com empresas internacionais (tecnologia na área florestal, indústria de bens de capital, capacidade técnica - gestão, clusters estabelecidos e grande mercado doméstico), florestas plantadas em desenvolvimento, disponibilidade e custo da mão de obra e câmbio favorável (conjuntural) são também citados por Tomaselli, Scheffler e Medeiros (2003). A transformação do carbono em commodity também pode resultar em facilitações para a implantação de florestas, principalmente em países com grande área disponível.

Edgar (1978) lembra ainda a possibilidade de associação das culturas intensivas com outras cadeias produtivas. Como exemplo, cita a disposição de determinados efluentes líquidos com a conseqüente fertilização de solos dos plantios florestais.

Apesar das vantagens e oportunidades para a implantação de novos plantios florestais no Brasil, observa-se que após o fim dos incentivos fiscais, não houve uma política estável de plantio e reposição florestal, nem em nível nacional quanto estadual, e o resultado foi o declínio das áreas plantadas. A redução da oferta de madeira no mercado, chamada pelas entidades do setor como "apagão florestal" (URURAHY, s.d.), numa alusão à crise do suprimento de energia elétrica é um fato previsto há pelo menos duas décadas atrás (HILLIS e BROWN, 1978). Essa situação é estreitamente relacionada com a lacuna de informações sobre as áreas plantadas que dificultavam a elaboração de estimativas concretas sobre o déficit de madeira.

No contexto brasileiro, a produção de inventários florestais no âmbito dos Estados, tem contribuído para reduzir essa lacuna de informações, a exemplo do Rio Grande do Sul e São Paulo (KRONKA, 2002), sendo que este último apresenta os efeitos acumulados ao longo de 10 anos sem a realização de um levantamento das condições das florestas plantadas.

Em São Paulo, foi verificada a existência de 770.010 hectares plantados em 2002, dos quais 611.516 ha correspondem às áreas com eucalipto $(79,4 \%)$ e 158.494 ha $(20,6 \%)$ com pinus. O total de plantios florestais corresponde a apenas 3,1\% da área do Estado. 
A área administrativa de Sorocaba, que engloba a Região Sudoeste do Estado detém quase a metade de todos os plantios do Estado (42,3\%) (Tabela 2 e Figura 10). Essa área engloba a Região de Governo (RG) de Itapeva, que compreende os municípios de Apiaí, Barra do Chapéu, Bom Sucesso de Itararé, Buri, Capão Bonito, Guapiara, Iporanga, Itaberá, Itaóca, Itapeva, Itapirapuã Paulista, Itararé, Nova Campina, Ribeira, Ribeirão Branco, Ribeirão Grande, Riversul e Taquarivaí, totalizando 18 municípios. Se isolados os plantios de pinus, somente nessa área administrativa são encontrados mais da metade de toda a produção do Estado (58,5\%).

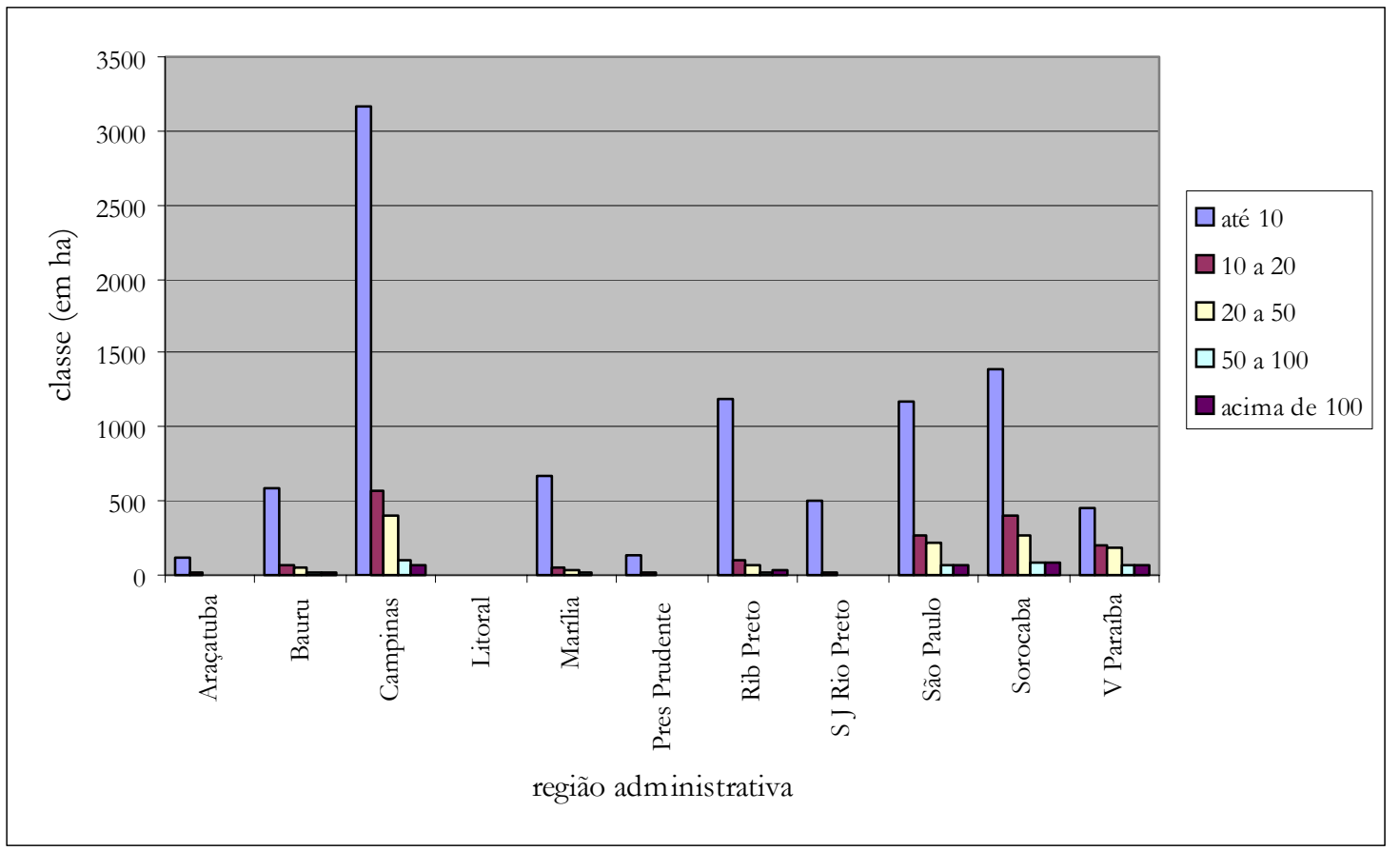

Figura 10. Áreas de plantios acordo com classes de superfície nas respectivas regiões administrativas eucalipto - detentores não identificados fonte: adaptado de Kronka (2002)

O Inventário Florestal também apresenta os dados através da visão de "pólos de reflorestamento" (Figura 2). A análise desse Inventário mostra os dez municípios com os maiores índices de plantios do Pólo de Reflorestamento de Itapeva/ Capão Bonito/ Buri (Figura 11) sendo que o total do Pólo é de 125.829 ha (16,3\% do total do Estado).

O destaque desse Pólo é que os plantios de pinus representam 38,9\% do total do Estado, mas há equilíbrio entre a quantidade de área plantada de pinus e de eucalipto nos dez municípios mais representativos (Tabela 3). Itararé e Itapeva, os principais municípios 
objetos de pesquisa do Projeto de Políticas Públicas detêm 28.253 ha e 22.532 ha de áreas plantadas, respectivamente.

Tabela 3. Relação dos dez municípios com índices mais expressivos de plantios florestais do Pólo de Reflorestamento de Itapeva/ Capão Bonito/ Buri.

\begin{tabular}{l|c|c|c|c|c|c}
\hline \multirow{2}{*}{ município } & \multicolumn{5}{c}{ gênero (área em ha) } \\
\cline { 2 - 7 } & eucalipto & $\%$ & pinus & $\%$ & total & $\%$ \\
\hline \hline Itapeva & 13.483 & 22,8 & 14.770 & 25,4 & 28.253 & 24,2 \\
\hline Itararé & 14.586 & 24,7 & 7.946 & 13,7 & 22.532 & 19,3 \\
\hline Buri & 9.391 & 15,9 & 11.075 & 19,1 & 20.466 & 17,6 \\
\hline Capão Bonito & 14.062 & 23,8 & 2.711 & 4,7 & 16.773 & 14,3 \\
\hline Nova Campina & 2.000 & 3,4 & 7.429 & 12,8 & 9.429 & 8 \\
\hline Apiaí & 1.370 & 2,3 & 6.367 & 11 & 7.737 & 6,6 \\
\hline Ribeirão Branco & 1.433 & 2,4 & 3.497 & 6 & 4.930 & 4,2 \\
\hline Itaí & 1.059 & 1,8 & 1.565 & 2,7 & 2.624 & 2,2 \\
\hline Paranapanema* & 1.277 & 2,2 & 1.265 & 2,2 & 2.542 & 2,2 \\
\hline Bom Sucesso de Itararé & 422 & 0,7 & 1.406 & 2,4 & 1.828 & 1,6 \\
\hline
\end{tabular}

*inclusão parcial

fonte: adaptado de Kronka (2002)

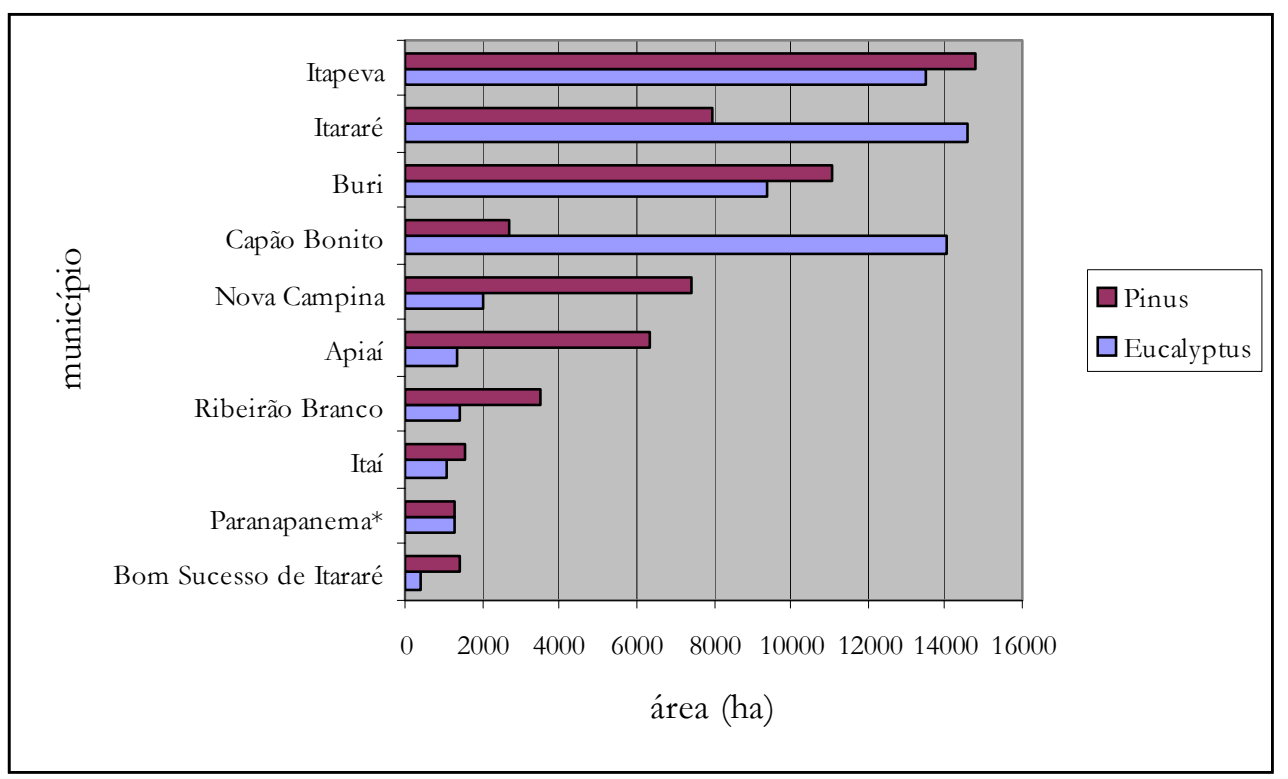

Figura 11. Área plantada dos dez municípios com quantidades mais expressivas no Pólo de Reflorestamento de Itapeva/ Capão Bonito/ Buri fonte: adaptado de Kronka (2002) 
A Figura 12 mostra a evolução dos plantios no Estado e explicita a diferença de área plantada entre a Região Sudoeste e as demais. O Inventário analisa os efeitos positivos que os incentivos fiscais tiveram no período entre 1962 e 1971-73, com 79,3\% de crescimento. $\mathrm{Na}$ última década houve um decréscimo da área plantada (804.598 ha em 1991-92 para 770.010 ha em 1999-2000 - 9,5\%) em todo o Estado, confirmando a questão recorrente sobre a falta de madeira no mercado, prevista para os primeiros anos da atual década.

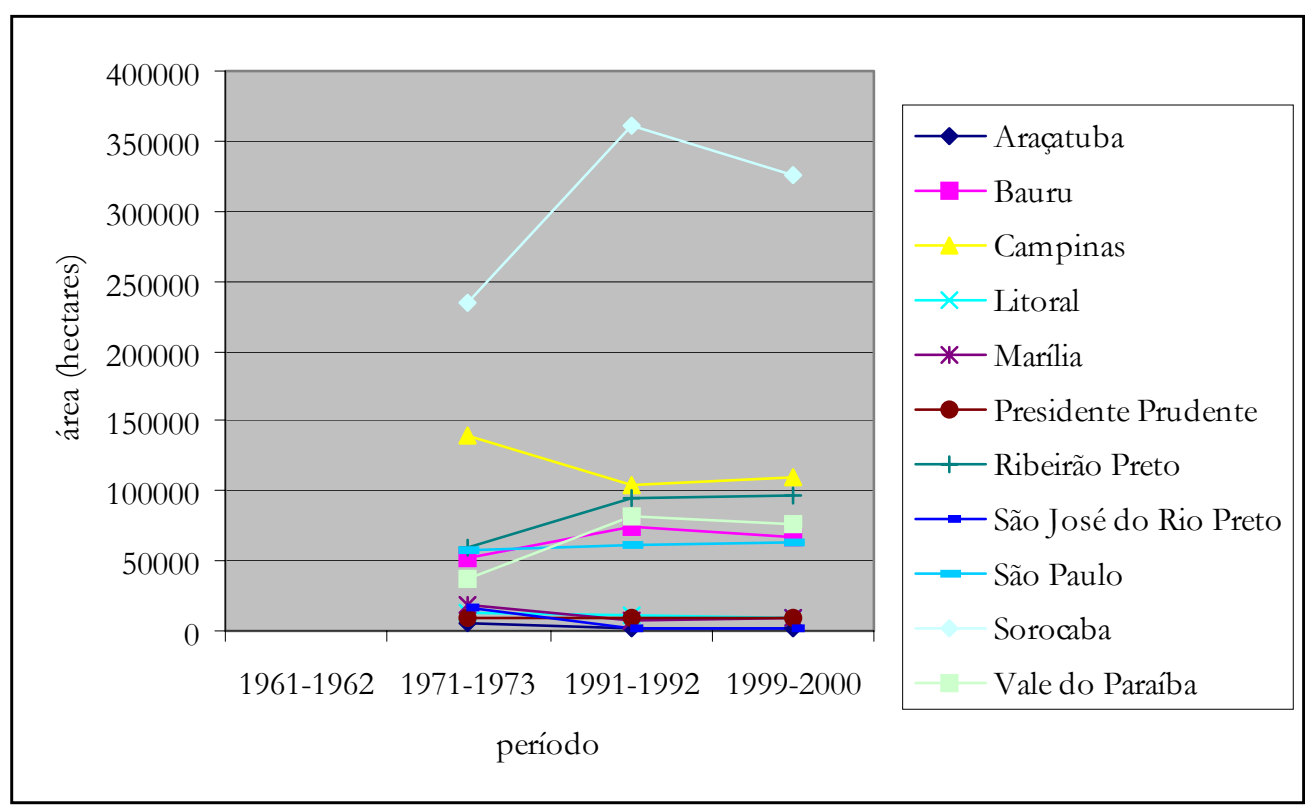

Figura 12. Evolução do reflorestamento (eucalipto, pinus e outros) no Estado de São Paulo, por região administrativa, nos períodos de 1961-62, 1971-73, 1991-92 e 1999-2000.

fonte: adaptado de Kronka (2002)

Especificamente na Região Administrativa de Sorocaba observa-se que quatro sub-regiões da Região Administrativa de Sorocaba concentram 42,9\% (139.986 ha) dos plantios existentes na Região. A partir de 1978, quando os plantios haviam atingido as maiores áreas cultivadas (170.532 ha - 39.733 ha de pinus e 130.799 ha de eucalipto), houve uma redução gradual até os dias de hoje de 13,6\% (26.672 ha) para o pinus e 10,2\% para o eucalipto (113.314 ha) (Figura 13). Esses dados foram extraídos de Galozzi et al citado por Kronka (2002) que realizou um levantamento em 30 municípios dessa região, durante os períodos de 1971-73, 1978, 1991-92 e 1999-2000, divididos por sub-regiões. Os dados da sub-região de Itapeva não são apresentados no Inventário Florestal. 


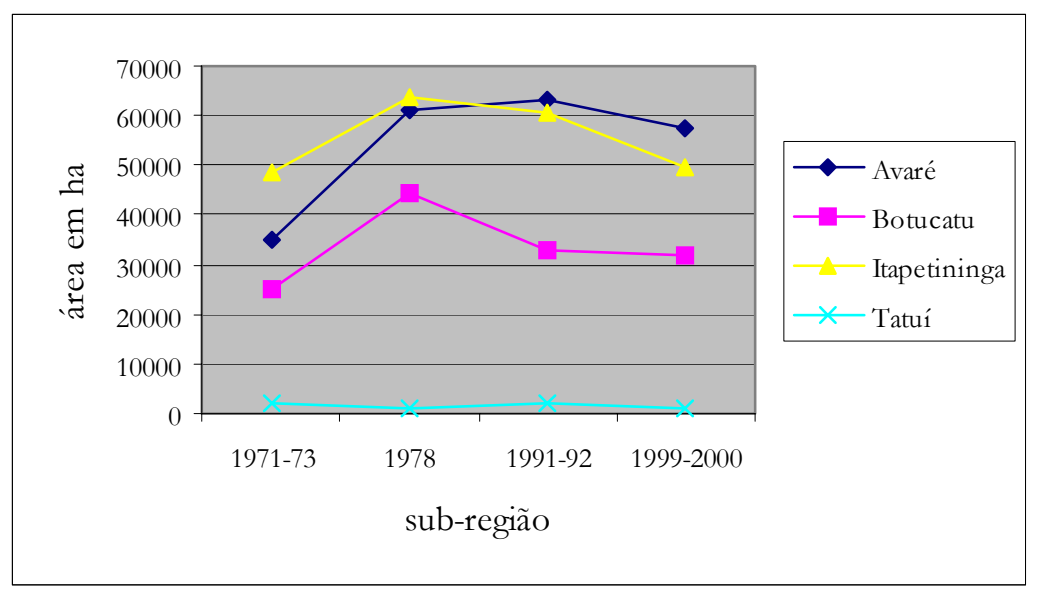

- Tatuí (Tatuí, Boituva, Cerquilho, Cesário Lange, Laranjal Paulista, Pereiras e Tietê)

- Botucatu (Anhembi, Aerópolis, Bofete, Botucatu, Conchas, Pardinho, Porangaba e São Manuel)

- Avaré (Avaré, Arandu, Cerqueira César, Cel. Macedo, Itaí, Itatinga, Paranapanema, Sta. Bárbara do Rio Pardo, Taquarituba, Manduri e Piraju)

- Itapetininga (Itapetininga, Angatuba, Guareí e São Miguel Arcanjo)

Figura 13. Evolução dos plantios florestais nas sub-regiões consideradas da Região Administrativa de Sorocaba nos períodos de 1971-73, 1978, 1991-92, 1999-2000 fonte: adaptado de Kronka (2002)

Essa redução nos plantios pode ter influenciado a ameaça de baixa oferta de madeira de plantios florestais em áreas não restritas ao Estado de São Paulo e o conseqüente aumento nos preços da tora, que pôde ser acompanhado desde o início do Projeto de Políticas Públicas "Habitação social em madeira de reflorestamento como alternativa econômica para usos múltiplos da floresta". Os dados apresentados na Figura 14 mostram que entre 1997 e 2004 houve, além da inversão da madeira mais valorizada, um aumento de mais de 100\% no valor pago pela madeira de pinus. A relativa estabilidade do preço da madeira de eucalipto em contraposição com o aumento do preço do pinus é uma questão que demanda maior atenção em pesquisas paralelas.

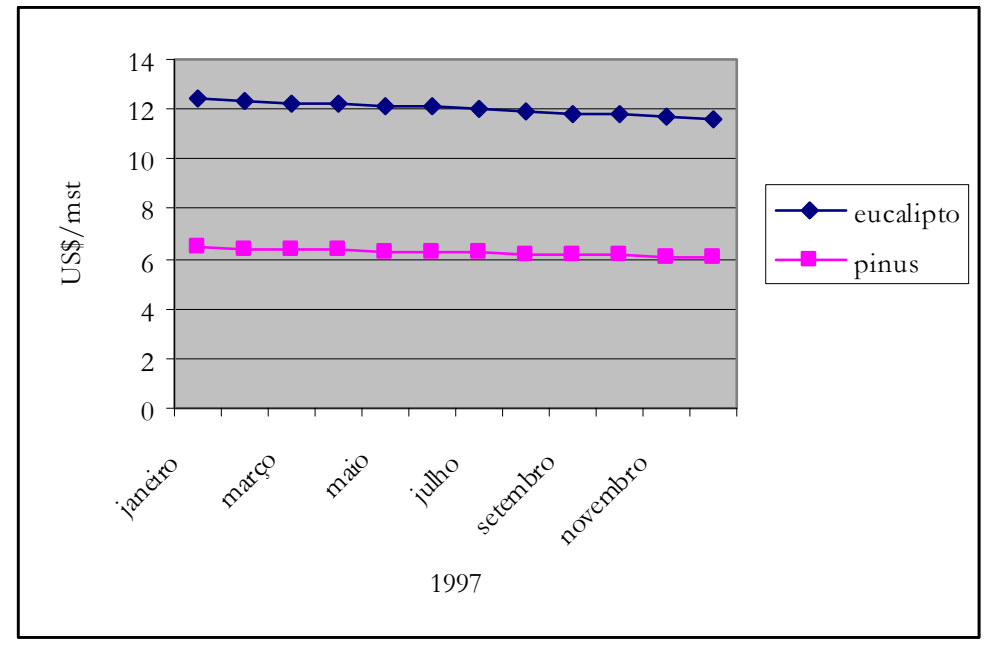

fonte: Fundação Florestal (1997) 


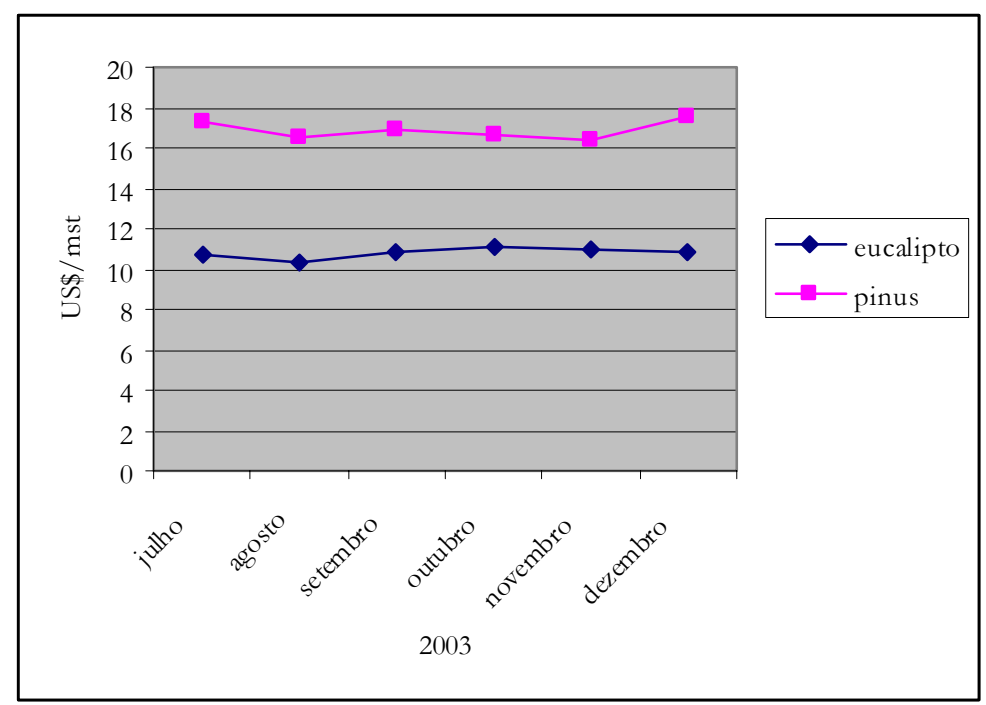

dados da região de Itapeva fonte: CEPEA (2003)

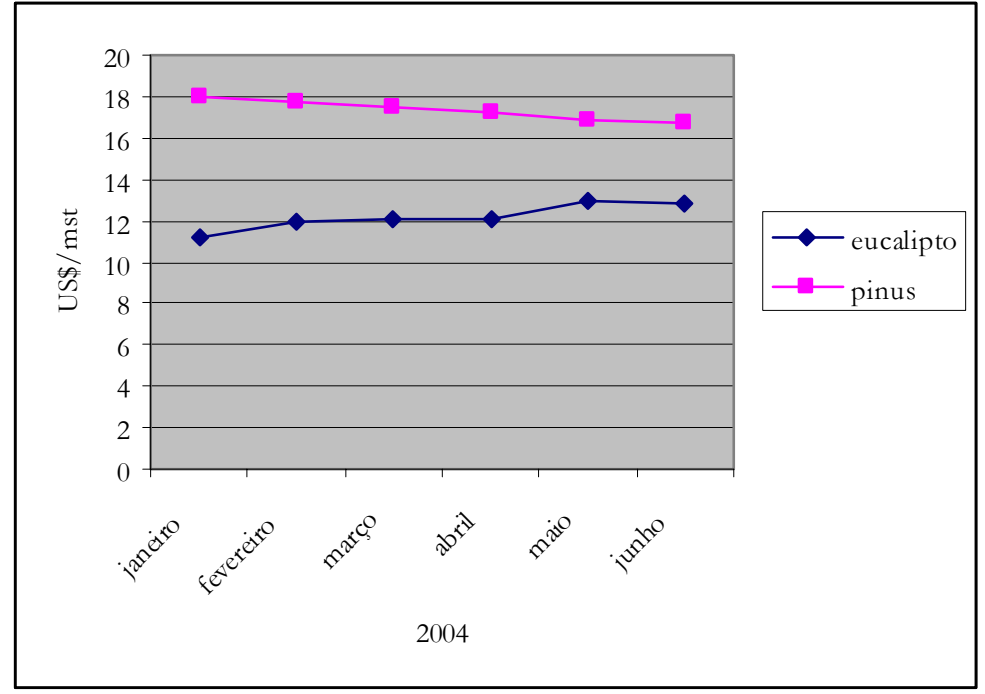

dados da região de Itapeva fonte: CEPEA (2003)

Figura 14. Preços médios de toras para serraria em pé no Estado de São Paulo fonte: Florestar Estatístico (1997 e 2004)

Outros fatores que podem ter contribuído para esse cenário e que não foram citado pelo Inventário é o aumento do controle do preço da madeira pelos grandes detentores, já que foi observado que grande parte dos plantios está concentrada nas empresas do setor de celulose e papel e também o potencial de crescimento das exportações de produtos de madeira sólida.

A legislação dos incentivos fiscais é criticada por Gonçalves (1992) considerando a série de distorções, sentidas até os dias atuais. A fixação de áreas mínimas para plantio (1.000 hectares para projetos em que haja participação comum de empresas), os mecanismos de burla para a obtenção dos benefícios, "soluções que apontavam sempre para o aumento da 
escala", "expansão de empresas não integradas às indústrias consumidoras" fizeram com que a atividade de plantios florestais se tornasse "uma atraente forma de aplicação para o capital".

Paralelamente à implantação e consolidação de grandes empresas, resultaram desse processo, as plantações de baixa qualidade e a expulsão de pequenos produtores das áreas rurais. "O pior de todo esse processo talvez seja o fato de a empresa, como representante de um modelo de desenvolvimento, ter criado com essa população padrões de relacionamento que geraram nela a idéia de que é a exploração florestal, e não as formas tradicionais de relacionamento entre os homens, sua cultura e seu ambiente, que representa o progresso" (GONÇALVES, 1992, p.81).

Derivado desse cenário é também o preconceito em relação ao "reflorestamento" existente no Brasil. Barrichelo chama de "síndrome de incentivos fiscais", que remete às extensas "monoculturas, êxodo rural, desalojamento da agricultura, concentração de terras, eliminação da fauna, prejuízos irreparáveis à biodiversidade, 'esterilização' do solo, desertos...” (BARRICHELO, 1990).

Um programa de plantios em escala nacional já havia sido proposto em 1990 no Projeto FLORAM, idealizado principalmente por Aziz Ab’Sáber, José Goldemberg, Leopold Rodes, Jacques Marcovitch e Werner Zulauf (AB’SÁBER, 1990). Com base nas pressões dos países internacionais sobre as potencialidades brasileiras para o seqüestro de gás carbônico da atmosfera (a questão em debate do momento) com a produção de florestas, foi criado um "somatório de projetos regionais, relacionados a uma correta tipologia de florestamentos ou reflorestamentos”. No projeto, essa ação, chamada erroneamente de "megareflorestamento", (já que propõe o plantio de 20 milhões de ha em duas ou três décadas) conta com uma variedade de tratamentos diferenciados: florestas "sociais", florestas para reabilitação de solos, florestas para bloqueio de desertificação, florestas para reperenização de drenagem, florestas híbridas de interesse sócio-econômico e cultural, florestas e bosques para bloqueio de [conurbação], bosques e áreas verdes periurbanas, revegetação e bosqueamentos viáveis para as regiões semi-áridas brasileiras.

Ao invés das monoculturas, a proposta do FLORAM é buscar um equilíbrio entre "industrialização de produtos florestais e a preservação do meio ambiente; entre a silvicultura de clones diferenciados e a biodiversidade; entre as atividades de grandes empresas e uma 'social-forestry' de pequenos e médios empreendimentos" 
(MARCOVITCH, 1990). Lima analisa que $72 \%$ da vegetação proposta no FLORAM são de espécies de rápido crescimento.

O FLORAM se assenta em diretrizes ecológicas, sociais e econômicas com "resultados equivalentes e simultâneos" a serem alcançados em todas as etapas do seu desenvolvimento (BARRICHELO, 1990).

Para Gonçalves (1992), a criação de um mecanismo de reposição florestal obrigatória é bem vista, já que o Estado passa a atuar apenas como um intermediador do processo, e o pequeno produtor agrícola é incluído na estratégia de produção florestal - o reflorestamento direto. Mas a consolidação dessa alternativa ainda tem barreiras a serem transpostas, conforme analisado na dissertação de mestrado (YUBA, 2000). No contexto gaúcho, a obrigatoriedade do pagamento da taxa de reposição florestal é vista pelos médios e grandes produtores florestais como um entrave ao livre desenvolvimento do mercado florestal (informação verbal) ${ }^{22}$, para o qual foi criado um projeto de lei, propondo a suspensão do seu pagamento no Estado. O posicionamento contrário a tal lei era defendido pela FARERGS ${ }^{23}$ (informação verbal) ${ }^{24}$.

A dificuldade de inclusão de pequenos produtores florestais é analisada pelo $\mathrm{IF}^{25}$, nos seus mecanismos de incentivos: 1981 - "Elenco de medidas para promover o reflorestamento e a conservação dos recursos florestais em São Paulo”, apresentado ao IBDF ${ }^{26} ; 1984$ "Proposta de política florestal para o Estado de São Paulo - Plano emergencial", apresentado ao Governo do Estado. Mesmo tendo previsto instrumentos legais para a implantação de plantios em pequenas e médias propriedades, estes "não foram suficientes para fazer frente aos lobbies do capital" (SÃO PAULO, 1990). A disparidade entre os preços de exportação de celulose e da madeira pagos aos agricultores pelas indústrias é apresentada na Figura 15 (SÃO PAULO, 1990). O IF atribui esse fato à falta de uma estrutura para o cumprimento da legislação.

\footnotetext{
${ }^{22}$ José Lauro de Quadros, então presidente da AGEFLOR - Associação Gaúcha de Empresas Florestais (1999)

${ }^{23}$ FARERGS - Federação das Associações de Reposição Florestal do Rio Grande do Sul

${ }^{24}$ Ricardo L. Süffert, representante da FARERGS (1999)

25 IF - Instituto Florestal

${ }^{26}$ IBDF - Instituto Brasileiro de Desenvolvimento Florestal extinto pela Lei $\mathrm{n}^{\circ}$ 7.732, de 14/02/1989, substituído pelo Instituto Brasileiro do Meio Ambiente e dos Recursos Naturais Renováveis - IBAMA
} 


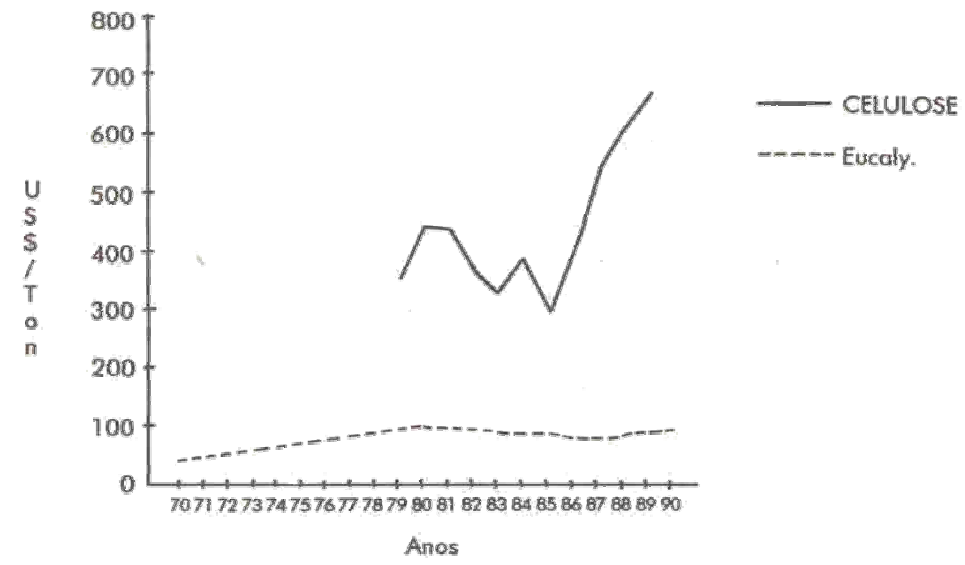

Figura 15. Preços da celulose $\left(\mathrm{FOB}^{27}\right)$ e custo da madeira $\left(\mathrm{CIF}^{28}\right.$, em US $\$ / \mathrm{m}^{\text {st }}$ sem casca) para a produção de 1 tonelada de celulose fonte: Secretaria do Meio Ambiente (1990)

Lima (1993) apóia a elaboração de políticas públicas - mecanismos de incentivos para a implantação de novas florestas (plano de custeio dentro da atividade agrícola, alteração nas normas de licenciamento dos processos da cadeia produtiva florestal) para a redução do cenário de insustentabilidade do setor florestal. Programas de financiamento para pequenos produtores (Programa de plantio comercial de florestas - Propflor - e PRONAF Florestal) são também citados. É proposta a criação de uma Secretaria de Florestas, no âmbito do ministério da Agricultura, o estabelecimento de política setorial e a simplificação da legislação.

Da maneira como se apresenta o cenário das florestas plantadas no contexto do Estado de São Paulo e mais especificamente da sua Região Sudoeste, é perceptível a proximidade de uma crise do setor, que se inicia com a baixa oferta de madeira no mercado, paralelamente à concentração das florestas nas empresas do setor de polpa e papel, com conseqüente aumento dos preços. Outra conseqüência possível é a diminuição paulatina da qualidade dos produtos oferecidos.

Para todas as cadeias produtivas que dependem da madeira de plantios florestais, esse cenário se constitui como um dos grandes gargalos para a sua sustentabilidade. Por isso, os longos prazos, característicos do setor florestal, demandam a definição de políticas que sejam capazes de suportar mudanças conjunturais, para que sejam compatíveis com a formação de reservas florestais. 


\subsubsection{Processo de beneficiamento}

Os processos e operações poderiam ser classificados de diferentes formas, de acordo com o enfoque que pretende ser dado. Da mesma forma, o grau de detalhamento de cada um dos processos pode ser bastante variável, em função dos objetivos da análise. Gonçalves (2000), do ponto de vista da usinagem da madeira, considera que o início desse processo se dê da colheita das toras até o beneficiamento. Para esse autor, a denominação de algumas atividades no processamento da madeira é proveniente da indústria de materiais metálicos.

Para efeito desta pesquisa, as delimitações entre os processos se dão de acordo com as entradas e saídas de produtos, ou seja, o processo de produção florestal termina com a saída de toras cortadas e o processo de beneficiamento se inicia com a chegada das toras no pátio para o desdobro.

\subsubsection{Operação de desdobro}

Gonçalves (2000), devido o enfoque da usinagem, apresenta um grau de detalhamento maior desse processo, considerando uma etapa inicial de descascamento, antes do desdobro.

O descascamento, necessário quando há tratamento preservativo a ser feito, apresenta vantagens pois contribui para o aumento da vida útil das ferramentas de corte, no controle do desenvolvimento de alguns insetos que atacam a madeira verde, na aceleração do processo de secagem, na redução dos gastos com transporte das toras quando executado na floresta e no aproveitamento da madeira nas serrarias (geração de peças brutas, produção de partículas, utilização do resíduo isento de casca) (GONÇALVES, 2000). Mas por outro lado, por ser uma operação a mais, aumenta o custo do processamento da madeira devendo ser avaliada a real vantagem da realização dessa operação no contexto local.

A operação de desdobro "[...] consta do processo de corte longitudinal das toras, com ou sem casca, empregado na produção de peças na forma de pranchas, tábuas, vigas, vigotas, caibros, sarrafos ou ripas" (GONÇALVES, 2000).

As toras são desdobradas utilizando-se serra de fita, serra circular múltipla, refiladeira, destopadeira e resserra para então serem secas. Essas duas operações (desdobro e secagem)

${ }^{28} \mathrm{CIF}$ - Cost, insurance and freight 
são dissociáveis pela possibilidade de haver mercados entre si, mas geralmente estão presentes no mesmo local e são controladas pelo mesmo agente.

A qualidade da tora (diâmetro, conicidade, uniformidade da superfície do fuste e presença de defeitos) e a sua adequação para uso em serraria influenciam o rendimento dessa etapa e conseqüentemente a produção de resíduos. O seu aproveitamento, o consumo energético no processamento e as condições de trabalho nas empresas são também questões que já estão na discussão de sustentabilidade.

Page descreve os possíveis problemas que podem resultar da usinagem de toras de eucalipto, principalmente nas toras de pequeno diâmetro: cerne frágil, bolsas e veios de resina, furos causados por insetos, batidas, tortuosidade, rachaduras, colapso, alta contração tangencial e tensões de crescimento. Essas características determinam um processo de usinagem diferente das empregadas para as coníferas, basicamente de transporte e desdobro mais rápidos (PAGE, 1978, p.327).

Visando a redução de perdas, Del Menezzi apresenta um estudo para o desdobro de eucalipto, investindo no conhecimento das tensões de crescimento combinado com processos de secagem adequados (DEL MENEZZI, 1999).

No Projeto "Caracterização de resíduos e otimização de processos produtivos em indústrias madeireira”, do Projeto PATME tipo “A”, programa criado pelo SEBRAE/SP e FINEP, com a parceria de dez serrarias da Região Sudoeste do Estado de São Paulo resultou em vários estudos significativos para as etapas de processamento da madeira, principalmente sobre a usinabilidade das espécies utilizadas nos plantios florestais (GONÇALVES et al, 2001). Nesse estudo, foram analisados os processos produtivos de 10 serrarias na região de Itararé e Itapeva com o objetivo de proposição de ações para otimizar a produção. Os problemas tecnológicos identificados foram:

- Seccionamento de toras de baixa produtividade, empregando-se moto serra, de forma imprópria quanto ao posicionamento das peças e postura de operador e auxiliares;

- Alimentação manual de toras no descascador;

- Acúmulo de produto inacabado (toras descascadas) na mesa de entrada da serra de desdobro.

Os subprodutos dessa operação são as cascas, costaneiras, serragem, resíduos do refilamento e de destopo, além de peças com defeitos como rachadura e empenamentos. Comparando o cenário analisado em 1988, percebe-se atualmente a grande valorização 
conseguida pelos sub-produtos e resíduos, com grande facilidade de comercialização (ver Quadro 19.

Considerando que, em média, um estéreo converte-se em $0,60 \mathrm{~m}^{3}$ de madeira em forma de resíduos de serraria do tipo costaneira e os índices de conversão $\left(\mathrm{m}^{\text {st }} / \mathrm{m}^{3}\right)$ de 3,98 , (considerado alto) e outros menores entre 2,58 e 2,88, de acordo com os dados de Gonçalves (2000) e Gonçalves et al (2001), é imprescindível o estudo de formas de aproveitamento dos resíduos do processamento, principalmente com a crescente valorização da madeira. Muitos autores atribuem o baixo rendimento à baixa qualidade das toras que estão sendo colhidas atualmente e também ao baixo nível tecnológico das serrarias.

Além da importância do trabalho de melhoramento genético para a produção de toras visando à produção de serrados, é relevante a produção de trabalhos sobre a utilização de resíduos ou madeira de rejeito comercial. Podem ser encontrados vários trabalhos recentes, que buscam a transformação em outros produtos ou a recuperação como madeira maciça.

César (2003) apresenta um estudo para aproveitamento das peças de terceira categoria ou de refugo para a produção de novas chapas, baseado no estudo de formas de colagem, definição de tipos de defeitos a serem eliminados e sua produção. Os resultados permitiram a obtenção de um material de maior valor agregado, havendo ainda necessidade de outros estudos sobre a adequação de equipamentos e qualidade das peças produzidas para viabilizar a sua produção em escala.

Outra forma de aproveitamento dos resíduos é a produção de partículas, que apesar de terem menor valor agregado, apresenta as seguintes vantagens, do ponto de vista do empresário (GONÇALVES, 2000):

- Diminuem o manejo com peças de madeira serrada;

- O armazenamento e o transporte necessitam de menos mão-de-obra;

- Requer menor espaço para armazenamento e favorece a utilização de equipamentos de movimentação (transportadores de correia e roscas sem fim);

- Para destino das partículas à produção de celulose, as pilhas de partículas reduzem a porcentagem de extrativos da madeira. 
A desvantagem é o aumento do custo de transporte, devido o aumento do volume a ser transportado, com baixa densidade $\left(1 \mathrm{~m}^{3}\right.$ de madeira maciça $=2,5$ a 2,7 $\mathrm{m}^{3}$ de partículas não compactadas).

Nas serrarias de Itararé foi observada uma mudança de comportamento em relação aos seus resíduos, ao longo do desenvolvimento do Projeto de Políticas Públicas. No início do Projeto (em 1998), um dos principais problemas ambientais era o acúmulo, a deposição irregular à beira de corpos d'água e a queima indiscriminada dos resíduos de madeira (cascas, costaneiras, resíduos do refilamento, serragem e cavacos, resíduos do destopo e outros pedaços pequenos). Em 2003, durante uma série de visitas realizadas às serrarias, identificou-se a existência de mercados compradores para os resíduos produzidos (FERREIRA JR., 2003) e com potencial de crescimento. Os resíduos são comercializados por praticamente todas as serrarias visitadas no levantamento, na forma de cavacos e serragem. A destinação dada aos subprodutos (costaneira, refilo, casca, destopo) é a venda para outras empresas que as utilizam como combustível para queima, composto, fabricação de papel e de MDF (GAVA e ALBANO FILHO, 2004).

\begin{tabular}{|c|c|c|c|c|}
\hline serraria & tipo & $\mathrm{m}^{\mathrm{st}} / \mathrm{mês}$ & $\mathrm{R} \$ / \mathrm{m}^{\mathrm{st}}$ & destinação \\
\hline J Medeiros Serraria - ME & $\begin{array}{l}\text { costaneira } \\
\text { casca } \\
\text { refilo } \\
\text { destopo } \\
\end{array}$ & - & 10,00 & combustível \\
\hline $\begin{array}{l}\text { Wagner Reginaldo Leite da Rosa - } \\
\text { ME }\end{array}$ & $\begin{array}{l}\text { costaneira } \\
\text { casca } \\
\text { refilo } \\
\text { destopo }\end{array}$ & - & - & combustível \\
\hline Madeireira Proença & $\begin{array}{l}\text { costaneira } \\
\text { casca } \\
\text { refilo } \\
\text { destopo } \\
\end{array}$ & - & - & - \\
\hline Serraria Vitório Ltda. & & & 10,00 & $\begin{array}{l}\text { fab. de papel } \\
\text { combustível }\end{array}$ \\
\hline $\begin{array}{l}\text { Indústria e Comércio de Madeiras } \\
\text { Klocker Ltda. }\end{array}$ & $\begin{array}{l}\text { cavaco descascado* } \\
\text { serragem } \\
\text { casca }\end{array}$ & $\begin{array}{c}400^{* *} \\
- \\
- \\
\end{array}$ & $\begin{array}{c}30,00^{* * *} \\
4,00 \\
\text { troca } \\
\end{array}$ & $\begin{array}{l}\text { fab. de MDF } \\
\text { combustível } \\
\text { composto }\end{array}$ \\
\hline V.L. de Camargo Madeiras & $\begin{array}{l}\text { costaneira } \\
\text { casca } \\
\text { refilo } \\
\text { destopo }\end{array}$ & 1080 & & combustível \\
\hline Planemade S.A. & $\begin{array}{l}\text { cavaco* } \\
\text { serragem }\end{array}$ & 2000 & 9,00 & combustível \\
\hline Serraria São Luiz de Taquarivaí Ltda. & cavaco* & 520 & - & combustível \\
\hline Chiaki Kakuda Embalagens - ME & $\begin{array}{l}\text { cavaco* } \\
\text { serragem }\end{array}$ & 800 & 9,00 & combustível \\
\hline Londani Madeiras & cavaco* & & 7,50 & combustível \\
\hline
\end{tabular}

Quadro 19. Resíduos da cadeia produtiva da madeira serrada - tipos e destinação fonte: Gava e Albano Filho (2004) 
$\mathrm{Na}$ pesquisa de produção de chapas de $\mathrm{MDF}$, o desempenho ambiental tem motivado a busca de alternativas menos impactantes, como a desenvolvida por Campos e Lahr (2003) que utilizam fibras extraídas a partir de resíduos de eucalipto e adesivos naturais. Os resultados satisfatórios cooperam para a busca de soluções para a utilização de resíduos ou peças não aptas para utilização em sua forma maciça. Desiderá e Zanin (2003) propõem e verificam a viabilidade de produção de um composto polimérico a partir de junção de serragem (Pinus elliottii e Eucalyptus saligna), a copos descartáveis pós-consumo (poliestireno de alto impacto) para substituir reforços sintéticos de fibra de vidro e de carbono nos polímeros. Os resultados com a introdução de $30 \%$ de serragem em peso mostram que a adição de serragem diminuiu a resistência ao impacto dos corpos de prova (de aproximadamente $60 \mathrm{~J} / \mathrm{m}$ para o corpo de prova sem adição de resíduos para $25 \mathrm{~J} / \mathrm{m}$ para os dois corpos de prova), mas aumentou a resistência à tração (de aproximadamente 24 MPa para $31 \mathrm{MPa}$ ). A espécie de madeira utilizada influenciou apenas a absorção de água, nos corpos de prova que continham serragem de Pinus elliottii, o que dá indícios do tipo de uso que se pode fazer com cada um dos compostos poliméricos.

O trabalho apresentado em Gonçalves, Souza e Barbosa (2002), propõe-se a analisar a produção de resíduos de dez serrarias da Região Sudoeste do Estado, com vistas à sua minimização. São propostas transformações no fluxo de produção, substituindo ou incluindo outras ferramentas e equipamentos e análise das condições de processamento da madeira nas operações de usinagem, a fim de evitar cortes com baixo índice de aproveitamento, causado, segundo os autores, pela falta de classificação de toras e peças. Neste trabalho, destaca-se a retroalimentação dos resultados da pesquisa para as empresas participantes do projeto, dando a oportunidade de aplicação dos dados de pesquisa para melhorar o processo produtivo das empresas e conseqüentemente aumentando a sustentabilidade da cadeia produtiva.

A vantagem desse método é a possibilidade de quantificar o resíduo por tipo (Figura 16), facilitando a identificação de formas de aproveitamento, seja na própria serraria ou em outros operações de transformação da cadeia produtiva. 


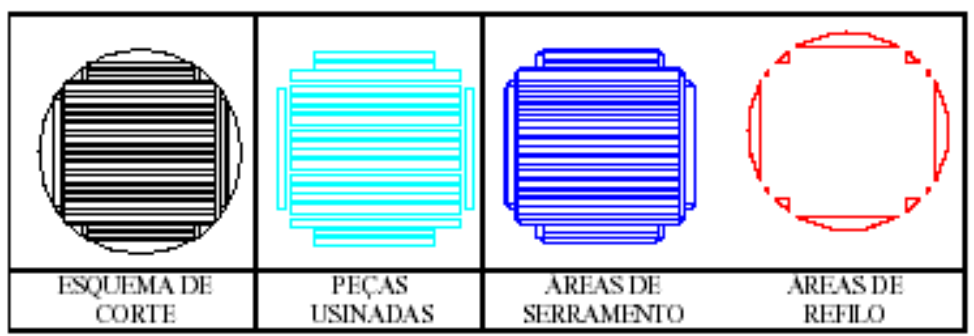

Figura 16. Exemplificação do modelo de simulação de corte efetuado em AutoCad 2000 fonte: Gonçalves, Souza e Barbosa (2002)

$\mathrm{Na}$ avaliação do $\mathrm{CWC}^{29}$, as operações que fazem parte do processamento são as mais fáceis de quantificar nas avaliações de sustentabilidade de materiais, já que todo o processo está sobre o controle humano. Os indicadores de consumo energético, emissões de gás carbônico e produção de resíduos são focalizados no trabalho de Barbosa, Ino e Shimbo (2000) sobre a sustentabilidade da cadeia produtiva da habitação em madeira de plantios florestais.

Os dados sobre o consumo energético no desdobro são apresentados em Barbosa, Ino e Souza (2003), considerando a produção de painéis parede, por $\mathrm{m}^{2}$ e $\mathrm{m}^{3}$ de madeira. Os valores obtidos não incluem o consumo energético dos elementos de ligação (pregos, parafusos, chapas de dentes estampados). Os dados obtidos são apresentados na Tabela 4.

Tabela 4. Valores de consumo de energia na fase de transformação primária da madeira nas serrarias.

\begin{tabular}{lcc}
\hline \multicolumn{1}{c}{ tipo de painel parede } & $\begin{array}{c}\text { consumo de energia } \\
\left(\mathrm{kwh} / \mathrm{m}^{2}\right)\end{array}$ & $\begin{array}{c}\text { consumo de energia } \\
\left(\mathrm{kwh} / \mathrm{m}^{3}\right)\end{array}$ \\
\hline \hline $\begin{array}{l}\text { Painel tipo 1 - Pórticos em pinus e fechamento em lambri com } \\
\text { Ossatura em pinus }\left(7 \mathrm{~m}^{2}\right)\end{array}$ & 1,80 & 28,02 \\
$\begin{array}{l}\text { Painel tipo } 2 \text { - Pilar viga em eucalipto, fechamentos externo em } \\
\text { deck horizontal e interno em lambri de pinus }\left(7,14 \mathrm{~m}^{2}\right)\end{array}$ & 1,79 & 27,05 \\
$\begin{array}{l}\text { Painel tipo 3 - Pilar viga em eucalipto, fechamentos externo em } \\
\text { tábua e mata junta e interno em lambri de pinus }\left(7,14 \mathrm{~m}^{2}\right)\end{array}$ & 2,25 & 24,75 \\
\hline $\begin{array}{l}\text { fonte: adaptado de Barbosa, Ino e Souza (2003) } \\
\end{array}$
\end{tabular}

fonte: adaptado de Barbosa, Ino e Souza (2003)

A tabela mostra valores próximos de consumo de energia, cujas diferenças são relacionadas aos tipos de corte, consumo e espessuras das peças.

${ }^{29} \mathrm{CWC}$ - Canadian Wood Council 
No levantamento de dados de custo, Voinson e Castagné comentam a falta de preocupação na coleta de dados nas serrarias, dificultando a apreensão dos dados relacionados ao desdobro. Um levantamento da $\mathrm{ABPM}^{30}$ fez uma estimativa genérica dos custos de desdobro e secagem:

Tabela 5. Estrutura dos custos de desdobro e secagem de pinus.

\begin{tabular}{l|c|c}
\multicolumn{1}{c|}{ item } & desdobro (\%) & secagem* (\%) \\
\hline \hline matéria prima & 55 & \\
\hline mão-de-obra (com encargos) & 34 & 54 \\
\hline amortização dos equipamentos & 3 & 15 \\
\hline energia & 4,5 & 27 \\
\hline $\begin{array}{l}\text { outros } \\
\text { * o custo de secagem corresponde a 10\% do custo de desdobro (valores de setembro } \\
\text { de 1983) } \\
\text { fonte: traduzido de ABPM apud Voinson e Castagné (1988) }\end{array}$
\end{tabular}

O custo mais alto da amortização dos equipamentos de secagem mostra uma preferência da época pelos investimentos na secagem da madeira. Por outro lado, a amortização dos equipamentos de processamento é relativamente baixa porque a maioria das empresas já as havia executado.

Num levantamento mais específico, foram obtidos os dados de uma empresa que processa toras de diâmetro acima de $15 \mathrm{~cm}$ e comprimento $4 \mathrm{~m}$. O sistema de desdobro é automático e a produção é de $16.000 \mathrm{~m}^{3}$ /ano. A secagem em estufa é realizada para $40 \%$ da madeira e o índice de aproveitamento total na serraria é de 33\%, considerada então normal para uma serraria de pinus.

Comparado com as serrarias francesas, as brasileiras têm maior quantidade de empregados, o que se deve ao baixo grau de automatização e ao baixo custo da mão-de-obra. Entretanto, a representatividade desse custo é significativa, se comparada com os demais itens (VOINSON e CASTAGNÉ, 1988). 


\subsubsection{Operação de secagem}

A secagem da madeira consiste no "processo de redução do seu teor de umidade a fim de levá-la a um teor de umidade definido, com o mínimo de defeitos, no menor tempo possível e de uma forma economicamente viável, para o uso a que se destina" (MARTINS, 1988).

Essa é a fase intermediária que "mais agrega valor ao produto final”, operação para a qual é observado um investimento maior das empresas na aquisição de equipamentos mais avançados. Apesar disso, pela presença de falhas no processo, essa etapa ainda é a principal causa do baixo padrão de qualidade da madeira serrada, de acordo com Ducatti, Jankowsky e Andrade (2001) e Voinson e Castagné (1988).

Martins aponta quatro métodos de secagem:

- natural: empilhamento padrão tipo gradeado (ou entabicado ou caixa) e empilhamento tipo tesoura (ou varal);

- solar;

- convencional (ou artificial ou estufa);

- desumidificação (secagem a baixas temperaturas).

Em uma primeira análise, a preferência, do ponto de vista da sustentabilidade, seria pelo método mais natural possível (solar), mas outros fatores também interferem na decisão do melhor processo a ser adotado (condições climáticas, fonte de energia, consumo energético, perdas de material resultantes de cada método, demanda de mão-de-obra, entre outros).

$\mathrm{Na}$ secagem, as madeiras leves mostram uma de suas principais vantagens: a velocidade de secagem. Comparada à imbuia, que demanda 2 anos ao ar livre ou 1 1/2 mês em estufa para secagem, o pinus pode ser seco em 24 horas numa estufa numa temperatura alta (VOINSON e CASTAGNÉ, op.cit.). Os fatores que influenciam a velocidade de secagem são a temperatura, a umidade relativa do ar, a circulação do ar e as características intrínsecas da madeira (espécie, espessura, cerne e alburno e orientação do corte).

O resultado dessa operação, se corretamente executado, é a obtenção de madeira com as seguintes características (MARTINS, 1988):

- Estabilidade das dimensões da madeira; 
- Redução dos riscos de manchas e apodrecimentos em madeira abaixo de $20 \%$ de umidade;

- Redução do peso;

- Aumento da resistência mecânica (flexão estática, compressão, dureza, cisalhamento);

- Melhora das características de trabalhabilidade (aplainamento, lixamento, furação, impregnação de produtos de tratamentos preservativos e de acabamento) em madeira abaixo de $20 \%$ de umidade;

- Propriedade de pega de adesivos;

- Melhor fixação de pregos e parafusos;

- Propriedades de isolamento térmico, elétrico e acústico.

Essas características definem um produto de melhor qualidade, mas se executado sem os conhecimentos de cada espécie de madeira, costuma gerar os defeitos de secagem, causados por diferenças de contração da madeira ao secar (por anisotropia ou por gradientes de umidade desenvolvidos na madeira durante a secagem), por tensão hidrostática (desenvolvida na parede das células) e por tensões de crescimento resultam em perdas de material (MARTINS, 1988; CAMPBELL e HARTLEY, 1978 JANKOWSKY apud TRUGILHO, 2002). Os defeitos comuns são as rachaduras, fendilhamentos e empenamentos (abaulamento/ encanoamento, encurvamento, arqueamento, torcimento e forma diamante).

Para minimizar os defeitos de secagem, os estudos apontam a necessidade de utilização de práticas de desdobro adequadas conjuntamente com cuidados no empilhamento (classificação do material por densidade e padronização - espessura, largura e comprimento, uso de separadores com espessura uniforme e bem alinhados), colocação de pesos sobre as pilhas de madeira serrada e definição de programas adequados de secagem (aumento do tempo do processo de secagem nas fases de uniformização e condicionamento) (MARTINS, 1988; DUCATTI, JANKOWSKY e ANDRADE, 2001; TRUGILHO et al., 2002). Essas ações visam à redução de perdas e também da mão-de-obra de classificação posterior.

Santos, Jankowsky e Andrade (2003) estudam a adequação da combinação da secagem natural com a secagem convencional (artificial) considerando as características de desenvolvimento de colapso e rachaduras na madeira de Eucalyptus grandis, buscando obter 
a melhor relação entre o tempo de secagem demandado e a obtenção de madeira de qualidade.

Em Ducatti, Jankowsky e Andrade, os autores observam que o uso do eucalipto ainda é visto com reservas pelo mercado consumidor, agravado pela falta de um suprimento constante, que fazem com que indústrias ainda prefiram a utilização de espécies nativas.

\subsubsection{Operação de usinagem}

"Compreende uma série de operações de usinagem, as quais podem ser classificadas e agrupadas em função do equipamento ou ferramental a ser utilizado" (GONÇALVES, 2000., p.100). "[...] referem-se basicamente aos trabalhos de usinagem por seccionamento das peças, aplainamento ou lixamento" (GONÇALVES, 2000, p. 114).

Nessa operação, Voinson e Castagné relatam a vantagem da baixa densidade do pinus: $\left(0,40 \mathrm{~g} / \mathrm{cm}^{3}\right)$ garantindo sucesso no seu uso como embalagens, brinquedos e acessórios domésticos. O autor ainda lembra que na indústria da construção civil informal essa característica tem um papel importante, pela trabalhabilidade do material.

Essa operação confere à madeira bruta a sua seção final, com os acabamentos. As suboperações e seus respectivos equipamentos são apresentados no Quadro 20:

\begin{tabular}{|c|c|}
\hline sub-operação & equipamentos \\
\hline \multirow{3}{*}{ serramento } & $\begin{array}{l}\text { circular: } \\
\text { serra circular simples } \\
\text { serra circular dupla } \\
\text { serra circular múltipla } \\
\text { serra circular seccionadeira- classificadora }\end{array}$ \\
\hline & $\begin{array}{l}\text { contínuo: } \\
\text { serra de fita simples } \\
\text { serra de fita conjugada }\end{array}$ \\
\hline & $\begin{array}{l}\text { alternativo: } \\
\text { horizontal monolâmina } \\
\text { vertical múltiplo }\end{array}$ \\
\hline fresamento & $\begin{array}{l}\text { plaina desempenadeira } \\
\text { plaina desengrossadeira } \\
\text { respigadeira simples e dupla } \\
\text { fresadora de perfis } \\
\text { plaina de múltiplas faces } \\
\text { fresadora vertical } \\
\text { fresadora copiadora }\end{array}$ \\
\hline
\end{tabular}




\begin{tabular}{|c|c|}
\hline sub-operação & equipamentos \\
\hline torneamento & $\begin{array}{l}\text { torno universal } \\
\text { torno copiador } \\
\text { torno cabeceiro } \\
\text { torno tubular }\end{array}$ \\
\hline furação & $\begin{array}{l}\text { furadeira vertical simples } \\
\text { furadeira horizontal simples } \\
\text { furadeira múltipla } \\
\text { furadeira oscilante } \\
\text { furadeira de corrente } \\
\text { furadeira alternativa }\end{array}$ \\
\hline lixamento & $\begin{array}{l}\text { lixadeira de cinta horizontal } \\
\text { lixadeira de cinta vertical } \\
\text { lixadeira orbital } \\
\text { lixadeiras de disco } \\
\text { lixadeira oscilante }\end{array}$ \\
\hline
\end{tabular}

Quadro 20. Sub-operações e equipamentos de usinagem de madeira serrada. fonte: Gonçalves (2000, p.115-121)

Relativos à produção de habitação, são produzidos nessa etapa os lambris, vigas, caibros, ripas, esquadrias entre outros. Na década de 80 o uso principal das madeiras de plantios florestais nas edificações eram os lambris, utilizados para forro e revestimento de parede. Atualmente, conforme o Quadro 21, observa-se que a gama de produtos aumentou.

Os produtos podem ser destinados diretamente para a pré-fabricação, para a montagem das habitações ou ainda passar pela etapa de tratamento preservativo.

No estudo setorial de produtos de madeira sólida, realizado pela $\mathrm{ABIMCI}^{31}$, a madeira serrada de pinus apresenta um crescimento anual de 7\% ao ano entre 1993 e 2002, mas que vem se atenuando nos últimos anos. As produções recentes foram de 8 milhões de $\mathrm{m}^{3} /$ ano enquanto a produção de madeira serrada tropical é de 14 milhões de $\mathrm{m}^{3}$ /ano desde 1995; desse montante, atualmente $80 \%$ é destinado ao mercado interno mas cada vez mais a tendência dos produtores é destinar os produtos para exportação, que cresceu 21\%/ano entre 1995 e 2002. O principal comprador dos produtos serrados de madeira de plantios florestais são os Estados Unidos, que absorvem quase 2/3 da produção (ABIMCI, 2004a). Do total de volume de madeira produzida no Brasil, 35\% é de pinus atualmente.

O Estudo também trata dos crescentes produtos de maior valor agregado - PMVA, que consiste no reprocessamento de madeira serrada para a produção de blocks, blanks 
(produtos intermediários), molduras (rodapé, meia-cana, cordão), painéis (colados lateralmente) e portas, principalmente. Todos os produtos têm alguma porcentagem destinada ao mercado externo, com média de $20 \%$, à exceção das molduras que têm quase a totalidade exportada (90\%) (ABIMCI, 2004b).

Voinson e Castagné relatam que o consumo de madeira de pinus no Brasil, por mais que direta ou indiretamente sejam destinados à produção de edificações, é baixa, estabelecendo uma comparação com o consumo da França, onde $2 / 3$ da madeira são destinados às edificações e 3/4 desse montante são provenientes de espécies resinosas. Não há na organização da cadeia produtiva uma política conjunta das indústrias para a introdução da madeira nas edificações, sendo identificados apenas esforços isolados de produtores de componentes.

Gava e Albano Filho realizaram em março de 2004, um levantamento dos produtos das pequenas e médias serrarias e as respectivas porcentagens de produção de madeira de primeira, segunda e terceira classe na Região Sudoeste de São Paulo, cujos dados são apresentados no Quadro 21.

\begin{tabular}{|c|c|c|c|c|}
\hline serraria & \multicolumn{2}{|r|}{$\mathrm{m}^{3} /$ mês } & destinação & $\mathrm{R} \$ / \mathrm{m}^{3}$ \\
\hline \multirow{3}{*}{ J Medeiros Serraria - ME } & $1^{a}$ & 92 & fábricas de embalagens & 270,00 \\
\hline & $2^{\mathrm{a}}$ & \multirow{2}{*}{75} & fábricas de embalagens & \\
\hline & $3^{a}$ & & fábricas de embalagens & \\
\hline \multirow{2}{*}{$\begin{array}{l}\text { Wagner Reginaldo Leite da Rosa } \\
\text { - ME }\end{array}$} & $1^{\mathrm{a}}$ & 163 & fábricas de pallets & $220,00^{*}$ \\
\hline & $2^{\mathrm{a}}$ & 70 & fábricas de sofás e estofamentos & $120,00^{*}$ \\
\hline \multirow{2}{*}{ Madeireira Proença } & $1^{\mathrm{a}}$ & 250 & & - \\
\hline & $2^{\mathrm{a}}$ & 36 & & - \\
\hline \multirow{2}{*}{$\begin{array}{l}\text { Indústria Comércio de Madeiras } \\
\text { Klocker Ltda. }\end{array}$} & $1^{\mathrm{a}}$ & 600 & exportação & - \\
\hline & $2^{a}$ & 400 & exportação & 230,00 \\
\hline \multirow{3}{*}{ V.L. de Camargo Madeiras } & $1^{\mathrm{a}}$ & 385 a 420 & exportação & - \\
\hline & $2^{a}$ & 110 a 120 & \multirow{2}{*}{$\begin{array}{l}\text { fábricas de embalagens } \\
\text { de acordo com a demanda }\end{array}$} & 220,00 \\
\hline & $3^{a}$ & 55 a 60 & & 180,00 \\
\hline \multirow{3}{*}{ Planemade S.A. } & $1^{\mathrm{a}}$ & 1009 & fábricas de embalagens & - \\
\hline & & & fábricas de pallets & \\
\hline & $2^{a}$ & 818 & & \\
\hline \multirow{3}{*}{$\begin{array}{l}\text { Serraria São Luiz de Taquarivaí } \\
\text { Ltda. }\end{array}$} & $1^{\mathrm{a}}$ & 228 & construção civil & 35,00 \\
\hline & & & fábricas de embalagens & 280,00 \\
\hline & $2^{\mathrm{a}}$ & 57 & fábricas de móveis & 170,00 \\
\hline
\end{tabular}

continua... 
continuação...

\begin{tabular}{|c|c|c|c|c|}
\hline serraria & \multicolumn{2}{|c|}{$\mathrm{m}^{3} / \mathrm{mês}$} & destinação & $\mathrm{R} \$ / \mathrm{m}^{3}$ \\
\hline \multirow{2}{*}{$\begin{array}{l}\text { Chiaki Kakuda Embalagens - } \\
\text { ME }\end{array}$} & $1^{\mathrm{a}}$ & 167 & fábrica de cerca para exportação & 240,00 \\
\hline & $2^{a}$ & 133 & de acordo com a demanda & 170,00 \\
\hline \multirow{2}{*}{ Londani Madeiras } & $1^{\mathrm{a}}$ & 120 & fábricas de embalagens & 240,00 \\
\hline & $2^{a}$ & 30 & de acordo com a demanda & 170,00 \\
\hline \multirow{2}{*}{$\begin{array}{l}\text { Valorem Ind. Com. Mad. Ass. } \\
\text { Florestal Ltda** }\end{array}$} & $1^{a}$ & & $\begin{array}{l}\text { cerca para exportação } \\
\text { viga para exportação } \\
\text { chapa colada tipo clear para exportação }\end{array}$ & $\begin{array}{l}\text { US\$125 } \\
\text { US\$ } 138 \\
\text { US\$ } 105 \\
\text { a } 170\end{array}$ \\
\hline & $2^{a}$ & & $\begin{array}{l}\text { viga } \\
\text { cabo de vassoura } \\
\text { chapa colada tipo finger joint } \\
\text { cerca }\end{array}$ & $\begin{array}{c}140,00 \\
50,00 \\
140,00\end{array}$ \\
\hline
\end{tabular}

OBS: o símbolo “-“ significa "não sabe’ ou 'não informou”. Os campos em branco não foram questionados *eucalipto

**dados de abril de 2002

fonte: Gonçalves, 2002; Barbosa, 2003 e visita técnica

Quadro 21. Características dos produtos de pequenas e médias serrarias da Reg. Sudoeste do Est. de SP. fonte: Gava e Albano Filho (2004)

Verifica-se que a variedade de produtos não se alterou desde o levantamento realizado por Gonçalves, Souza e Barbosa (2002). Da mesma forma que a análise de Voinson e Castagné, o quadro mostra a estratégia das empresas de diversificação de produtos, para abranger diferentes mercados consumidores e evitar as possíveis crises de cada setor. À exceção das grandes empresas, as menores continuam a comercializar produtos de baixo valor agregado, como pallets, embalagens para verduras e cabos para vassouras.

Valarelli e Gonçalves (2002) também tratando do mesmo contexto, buscou o aumento da produtividade de madeira serrada de pinus, somada à melhoria de qualidade e redução de custos. O estudo resultou na proposição de alterações como a otimização de operações de corte e automatização de sistemas de segurança e de alimentação para as serrarias.

\subsubsection{Operação de tratamento preservativo}

Os problemas ambientais gerados pelo uso de produtos químicos para o tratamento preservativo da madeira é um dos aspectos mais citados na literatura sobre sustentabilidade de materiais de construção. 
A controvérsia é a utilização de produtos tóxicos para o tratamento preservativo, visando o aumento da sua durabilidade. Embora seja comprovado que os produtos tratados quimicamente durem mais, a polêmica está na toxicidade dos produtos utilizados e possível contaminação do homem e do meio ambiente, principalmente nas usinas de tratamento. $\mathrm{E}$ o tratamento resulta na produção de um novo resíduo, que já não se degrada com a mesma facilidade que a madeira não tratada.

A função do tratamento preservativo é "introduzir na madeira substâncias que retardam o processo natural de deterioração causada por organismos (bactéria, fungo, inseto, crustáceo, molusco etc)", conforme Lepage e Cavalcante (1986), garantindo e aumentando a durabilidade da madeira.

Mas devido os altos custos para o tratamento, nem sempre essa operação faz parte da cadeia de produção da habitação em madeira, dando vazão à ocorrência de conseqüentes ataques de fungos e insetos que acabam contribuindo para incrementar a resistência dos usuários sobre a utilização da madeira como material principal na construção de habitações.

Naturalmente, quanto maior a gama de organismos abrangidos pelo produto, maior será a sua eficácia. Entretanto, maior será o seu nível de toxicidade. A principal questão é a possibilidade de contaminação do solo, ar e água pelos produtos utilizados, durante e após o tratamento. Uma extensa lista de produtos para tratamento, de diferentes níveis de toxicidade, é apresentada em Richardson (1978).

O GBD apresenta uma lista comparativa dos impactos causados por produtos químicos presentes nos tratamentos preservativos no Quadro 22. Quando não há possibilidade de descartar a utilização do tratamento, os compostos à base de boro, seguidos de compostos à base de zinco/ cobre/ fluoretos em base aquosa são indicados pelo GBD como opções menos tóxicas para humanos e meio ambiente.

\begin{tabular}{|c|c|c|c|c|c|c|}
\hline produtos & 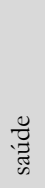 & 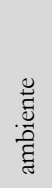 & 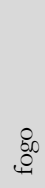 & 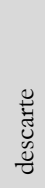 & 总 & 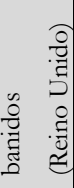 \\
\hline creosoto & & & & & & \\
\hline boro & & & & & & \\
\hline arsênico & & & & & & \\
\hline sais de cromo & & & & & & \\
\hline sais de cobre & & & & & & \\
\hline
\end{tabular}

continua... 
continuação..

\begin{tabular}{|c|c|c|c|c|c|c|}
\hline produtos & $\frac{\mathscr{U}}{\tilde{\tilde{E}}}$ & 节 & $\stackrel{8}{8}$ & 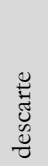 & $\begin{array}{l}\stackrel{\mathscr{0}}{\mathscr{E}} \\
\tilde{\Xi}\end{array}$ & 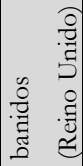 \\
\hline fluoretos & & & & & & \\
\hline Dieldrin & & & & & & \\
\hline pentaclorofenol & & & & & & \\
\hline Lindane & & & & & & \\
\hline dichlofluanid & & & & & & \\
\hline $\begin{array}{l}\text { tributyl tin oxide (óxido de B15 } \\
\text { (tributil estanho) TBTO }\end{array}$ & & & & & & \\
\hline permetrina & & & & & & \\
\hline naftenato de cobre e zinco & & & & & & \\
\hline acypetacs zinco & & & & & & \\
\hline
\end{tabular}

diluentes

\begin{tabular}{|l|l|l|l|l|l|l|}
\hline base aquosa & & & & & & \\
\hline base de solvente & & & & & & \\
\hline
\end{tabular}

Pior ou maior impacto

Segundo maior impacto

impacto Menor

Impacto pequeno mas significante

Impacto significativo não encontrado nas pesquisas

Quadro 22. Comparação do impacto ambiental de produtos químicos utilizados em tratamentos preservativos.

fonte: traduzido de Green Building Digest (1996, p.6)

O tratamento pode ser feito em processos sem pressão (imersão, pincelamento ou aspersão) ou com pressão (autoclave em usinas de preservação), definido de acordo com o risco das condições de uso (LEPAGE, 1986; CARLOS, 1995). Os fatores que afetam o tratamento preservativo são a espessura do alburno, os danos causados pela furação, a pressão de tratamento do cerne, a difusão no cerne e a durabilidade natural (TAMBLYN, 1978).

Lepage e Cavalcante afirmam que uma vez tratada, a madeira não afeta a flora e fauna do entorno onde é utilizada e que a madeira tratada não representa nenhum risco para o meio ambiente. Mas Cooper comenta que na realidade há muita madeira sendo comercializada 
sem que o processo de fixação do produto preservativo $\mathrm{CCA}^{32}$ esteja completo, já que esse processo depende de reações químicas complexas e de muitos fatores (temperatura, umidade relativa, espécie da madeira e o preparo do CCA). Lepage e Cavalcante relatam que a fixação completa do preservativo demanda cerca de 1 mês, tendendo a demandar mais tempo em temperaturas mais baixas (COOPER, 1993).

Se o produto preservativo não estiver bem fixado à madeira, certas condições tornam o produto perigoso. O dano ambiental do arsênico lixiviado depende da valência (o arsênico trivalente adere mais facilmente a tecidos biológicos e tem toxicidade aguda e crônica maiores que o arsênico pentavalente, que é o estado encontrado nos produtos preservativos), mas Cooper relata casos em que foi encontrado arsênico trivalente, que aparentemente aumenta com o tempo de exposição da madeira em uso.

$\mathrm{O}$ perigo do cromo também está na sua valência. $\mathrm{O} \mathrm{Cr}^{\mathrm{VI}}$ pode facilmente passar por membranas biológicas e sendo um agente oxidante, pode resultar em problemas respiratórios, câncer, problemas de pele e dermatites. Além disso, reage muito lentamente com os componentes do solo, fazendo com que se mova da mesma forma que a água dos lençóis freáticos. $\mathrm{O} \mathrm{Cr}^{\mathrm{III}}$ é menos tóxico porque não é corrosivo e tem baixa permeabilidade nas membranas, além de ser facilmente incorporado pelo solo. É o tipo presente nas madeiras tratadas (COOPER, 1993).

Cooper relata trabalhos em que foram encontradas concentrações entre 0 e 10 ppm de CCA na água lixiviada (Tabela 6), acima dos limites estabelecidos pelos critérios canadenses para a qualidade da água:

Tabela 6. Critérios para avaliação da contaminação de água canadense.

\begin{tabular}{l|c|c|c}
\hline & cobre (ppm) & cromo (ppm) & arsênico (ppm) \\
\hline \hline água potável & 1,0 & 0,050 & 0,025 \\
\hline água de ambientes aquáticos & 0,002 a 0,004 & 0,002 a 0,02 & 0,05 \\
\hline fonte: traduzido e adaptado de Cooper (1993)
\end{tabular}

Testes feitos em situações reais, como a de MURPHY e DICKINSON apud COOPER (1993) descobriram que as concentrações de material lixiviado eram independentes do pH inicial das chuvas, possivelmente pela neutralização da água pelo solo. O solo arenoso

${ }^{32} \mathrm{CCA}$ - arseniato de cobre cromatado 
apresentou quantidade maior de material lixiviado do que os solos argilosos ou ricos em material orgânico.

Por causa da forte interação do arsênico com os componentes do solo (ferro, alumínio e cálcio) há receio de um alto potencial de contaminação do entorno dos produtos de madeira tratados. Mas Cooper apresenta dados da distribuição do arsênico no entorno de postes de pinácea com 32 anos de uso (Tabela 7) e mostrou que as concentrações são mais altas a distâncias muito curtas (centímetros).

Tabela 7. Concentração de arsênico no solo no entorno de postes de madeira tratada.

\begin{tabular}{c|c}
\hline distância $(\mathrm{mm})$ & nível de arsênico no solo (ppm) \\
\hline 0 & 53 \\
\hline 50 & 36 \\
\hline 100 & 23 \\
\hline 150 & 16 \\
\hline
\end{tabular}

Também preocupante é a possibilidade de contaminação de alimentos cultivados no solo que contém produtos químicos lixiviados. O crescimento das plantas começa a ser afetado quando os níveis chegam a 170 ppm e afetam totalmente com 7000 ppm, segundo Grant e Dobbs apud Cooper (1993).

No contexto de baixo nível tecnológico citado, não é raro verificar que procedimentos de cuidado ideais raramente ocorrem, sendo muito mais comum na realidade a falta de informação dos trabalhadores e o manuseio e descarte incorretos dos produtos tratados.

Na usina de tratamento, Lepage e Cavalcante falam dos riscos de contaminação de pessoas e meio ambiente através de vazamentos nos equipamentos e escorrimento da madeira recém-tratada, tornando solo e água tóxicos. $\mathrm{Na}$ água, os efluentes podem também alterar a demanda de oxigênio da corrente de água onde são lançados. Na usina, as principais fontes de poluição são, de acordo com Lepage e Cavalcante (1986):

- Emprego de vapor para secar madeira ou limpar a autoclave;

- água de resfriamento utilizada por usinas equipadas com condensadores barométricos;

- água utilizada na limpeza dos equipamentos da usina; 
- escorrimento do produto preservativo de madeira recém-tratada;

- lixiviação de produto preservativo de madeira tratada que se encontra no pátio;

- poluição causada por acidentes;

- embalagens de produtos preservativos.

Os métodos descritos para reduzir o grau de poluição nas usinas caracterizam-se basicamente pela contenção do preservativo do solo do pátio e tratamento da água utilizada no processo.

O potencial de contaminação de pessoal que trabalha nessas usinas, desde que utilizem EPI's e ajam de acordo com as normas, foi considerado baixo num estudo realizado com mais de 600 operários que lidam com creosoto, pentaclorofenol e CCA usados em processos sob pressão (FLICKINGER apud LEPAGE e CAVALCANTE, 1986). Nesse estudo, foram constatados poucos casos de afecções dérmicas.

A deposição em aterros, por mais preparados que sejam para receber tais tipos de resíduos é um recurso limitado pelo espaço disponível, agravado pela dificuldade de degradação (WILSON, 1997). E a incineração, quando ocorre a temperaturas inferiores a $1100^{\circ} \mathrm{C}$ provoca emissões de gases perigosos (PASEK, 1994).

A análise de variáveis de outras dimensões (política - participação na tomada de decisões; econômica - arrecadação de tributos, número de empregos, duração do emprego, renda dos trabalhadores; e social - direitos trabalhistas) dessas diversas operações do processo de beneficiamento ainda são demandadas para possibilitar a realização de estudos mais abrangentes.

\subsubsection{Processo de projeto}

Através do processo de projeto, várias características determinantes da sustentabilidade (participação do usuário no processo de projeto, durabilidade, redução de custos, acessibilidade, impactos ambientais, entre outros) podem ser definidas, dando aos projetistas a responsabilidade da adequada especificação dos materiais e técnicas a serem utilizados. O CWC diz que uma escolha equivocada pode não gerar impactos relevantes na construção mas pode ser significativa durante o uso, "como nos edifícios envidraçados com alto consumo de energia elétrica para resfriamento" ou na desmontagem, quando são utilizados materiais de difícil reciclabilidade. 
A madeira é freqüentemente questionada quanto à sua adequação ao clima e às culturas construtivas brasileiras. Voinson e Castagné são alguns dos autores que fazem esse questionamento, devido à diversidade de insetos e fungos e o clima de boa parte do território brasileiro (quente e úmido) não ser propício para a exposição da madeira ao sol ou chuva. A umidade de equilíbrio da madeira no Brasil está entre 15 e 18\%, enquanto que na Europa é de 12\% e nos EUA, $8 \%$.

Por outro lado, o CWC aponta na dimensão ambiental da sustentabilidade o consumo energético da madeira como fator favorável à sua utilização; utilizando o software Athena, compara os dados de paredes feitas em aço e em madeira: a parede de aço usou três vezes mais energia, produziu três vezes mais gás carbônico, usou 25 vezes mais água e teve impacto muito maior na qualidade da água e do ar (CWC, 1996).

Da mesma forma, Pravia e Ghelen (2002), baseados numa estimativa, comparam as diferenças de custo entre uma edificação de alvenaria e de madeira (33\% menor) e tempo de execução ( $75 \%$ menor) e enfatizam o custo reduzido da madeira de eucalipto e pinus comparado com espécies nativas. Entretanto, qualquer avaliação comparativa requer que seja considerado o mesmo desempenho (estrutural, térmico, acústico) de cada um dos sistemas construtivos.

Para vencer a baixa utilização da madeira na construção civil, Miyadaira e Bittencourt (2002) propõem um banco de dados informatizado que possibilite a comparação entre as habitações pré-fabricadas oferecidas no mercado, já que apresentam diferentes graus de qualidade. As características das empresas fabricantes (receio da concorrência no setor e a quase inexistência de um corpo técnico especializado e capacitado a responder as questões específicas do sistema, além da falta de investimentos em parcerias com órgãos de pesquisa como obstáculos à obtenção dos dados da pesquisa) são indícios do comportamento dos agentes desse processo na cadeia produtiva. Os autores observam nesse levantamento realizado a instabilidade das empresas no mercado, quando cinco das vinte e duas empresas cadastradas na pesquisa não se mantiveram no mercado (município de São Paulo). Os sistemas construtivos são classificados de acordo com o sistema de vedação utilizado:

- painéis portantes ou não de lambris horizontais ou verticais;

- painéis portantes ou não compostos de ossatura e vedação externa e interna;

- tábua e mata junta. 
Os sistemas comumente comercializados têm pouco das inovações tecnológicas propostas geralmente em pesquisas acadêmicas. Esses têm buscado a otimização no uso da madeira e novos produtos que conjugam diferentes materiais (concreto e madeira, madeira e fibras de carbono e de vidro, entre outros) (FIORELLI e DIAS, 2002, MOREIRA et al, 2002; FARIA e MACÊDO, 2002; LATORRACA, 2002).

Questão relevante para a sustentabilidade política na construção civil é a participação do morador no processo de projeto das unidades habitacionais. Arruda apud Arruda e Ino (2002) focalizando a participação de mutirantes no processo de projeto, organiza cinco etapas gerais de elaboração do projeto arquitetônico:

- fase 1: levantamentos preliminares e estudo de viabilidade;

- fase 2: concepção geral e estudo preliminar;

- fase 3: elaboração do anteprojeto;

- fase 4: produção experimental;

- fase 5: elaboração do projeto do produto e da produção.

Shimbo, L. e Ino (2004) analisam essa questão. O estudo de caso foi a elaboração do projeto arquitetônico com a participação de oitenta famílias do assentamento rural Fazenda Pirituba, em Itapeva/ SP, no contexto do Projeto de Políticas Públicas. As discussões em torno da madeira evidenciaram a polêmica sobre as preferências de materiais de construção, sobre as quais as autoras concluem que os aspectos favoráveis à sustentabilidade apontados (ambiental, técnico e econômico) não são igualmente compreendidos e aceitos pelas famílias. O debate da rejeição à madeira pelos usuários constitui uma das grandes questões da sustentabilidade cultural da cadeia produtiva da habitação em madeira.

Algumas características culturais em relação à habitação em madeira são reunidas por Voinson e Castagné (1988):

- A imagem da habitação em madeira não é positiva no Brasil por estar associada a uma habitação em escala ou provisória (barraco);

- o mercado está limitado a habitações secundárias (praia ou campo)

Para agravar, os sistemas construtivos de habitações em madeira têm sua competitividade ameaçada pelos sucessivos aumentos nos preços das toras (conforme observado na Figura 14) e pelas restrições de legislação de construção impostas pelo antigo BNH. 
As diretrizes para o projeto de habitação social em pinus, definidas por Arruda e Ino (2002) são sintetizadas em:

- orientar processos construtivos semi-industrializados;

- resultar em métodos construtivos racionalizados;

- ser concebido sob os princípios da coordenação modular;

- assegurar a capacidade evolutiva da habitação.

A disposição dos programas de financiamento para a flexibilização dos critérios de avaliação dos materiais de construção é um passo importante para o desenvolvimento da cadeia produtiva da madeira. Voinson e Castagné relatam que o fato do $\mathrm{BNH}^{33}$ ter sido orientado para a construção de habitação em alvenaria e concreto limitou muito o uso da madeira nas edificações, num país cuja atividade de produção de habitação é muito dependente da política de financiamento.

Visando ao atendimento dos requisitos de redução de perdas na execução e de custos finais da habitação, referentes à dimensão econômico-ambiental da sustentabilidade, Galinari e Ino (2004) apresentam as variáveis de racionalização do projeto arquitetônico de sistemas construtivos em madeira. As variáveis de projeto são:

A) Racionalização do desenho arquitetônico:

- Modulação básica com dimensões relacionadas com as dimensões dos materiais de mercado, da madeira disponível e dos ambientes da casa;

- Utilização de formas geométricas simples na configuração dos ambientes, (ex: utilização de formas ortogonais);

- Integração dos ambientes e redução das áreas de circulação;

- Concentração de instalações hidro-sanitárias;

- Possibilidade de ampliação da habitação com novos ambientes

- Clareza e didática na representação das informações do projeto arquitetônico e detalhes do sistema construtivo;

B) Racionalização no detalhamento do sistema construtivo: 
- Repetição no dimensionamento das peças ou utilização de dimensões múltiplas;

- Menor variabilidade no desenho/ dimensões dos componentes e elementos construtivos;

- Menor quantidade de elementos e componentes construtivos;

- Menor quantidade de elementos metálicos nas ligações;

C) Racionalização na especificação de materiais:

- Menor variedade de materiais de construção;

- Utilização de materiais facilmente encontrados no mercado (caixilhos, telhas, materiais elétricos e hidro-sanitários, etc.).

- Utilização de madeira com dimensões disponíveis localmente;

- Utilização de materiais que exijam menos transporte;

- Priorizar a utilização de métodos de secagem natural da madeira;

- Utilização de tratamento preservativo diferenciado para peças com maior exposição às intempéries e agentes de deterioração;

- Menor usinagem (processamento) na fabricação de componentes construtivos em madeira;

- Utilização de materiais com menor consumo energético na sua produção, além da madeira;

- Possibilidade de reaproveitamento de peças após a desmontagem da unidade habitacional.

A partir desses dados, as autoras verificaram a necessidade de garantir também a construtibilidade com qualidade do projeto que segue tais requisitos. Com isso, foram formuladas outras variáveis de racionalização para a produção da habitação, apresentadas no item a seguir.

As tendências futuras sobre os requisitos para materiais e sistemas construtivos e a inserção da madeira nesse novo contexto são analisadas por Bayne et al. (2002). As previsões de requisitos para os materiais e a relação desses com a madeira são apresentados no Quadro 23. 


\begin{tabular}{|c|c|}
\hline implicação nos produtos de madeira & implicações na tecnologia de processamento da madeira \\
\hline $\begin{array}{l}\text { Demanda } \\
\text { Aumento na demanda por produtos de valor } \\
\text { agregado em mercados desenvolvidos } \\
\text { Aumento na demanda em mercados em } \\
\text { desenvolvimento por produtos de madeira } \\
\text { tradicionais } \\
\text { Desejo pela madeira como material de } \\
\text { construção devido às afinidades }\end{array}$ & $\begin{array}{l}\text { Desenvolvimento de alto valor, alto } \\
\text { desempenho de produtos de madeira de } \\
\text { florestas manejadas, com menor custo do que os } \\
\text { tradicionais - dimensão econômica } \\
\text { Aumento do reuso de produtos de madeira em } \\
\text { acabamentos internos - dimensão ambiental }\end{array}$ \\
\hline $\begin{array}{l}\text { Questões ambientais } \\
\text { Produtos de construção sustentáveis } \\
\text { Componentes livres de produtos tóxicos } \\
\text { Produção sem resíduos } \\
\text { Produtos que são eficientes ambiental e } \\
\text { energeticamente que são saudáveis e atóxicos }\end{array}$ & $\begin{array}{l}\text { Tecnologias de reciclagem, reuso na demolição } \\
\text { de edificações e reprocessamento de } \\
\text { componentes - dimensão ambiental } \\
\text { Análises do ciclo de vida e selos verdes para } \\
\text { produtos de madeira - dimensão ambiental } \\
\text { Avaliações energéticas para edificações - } \\
\text { dimensão ambiental/econômica } \\
\text { Tecnologias de preservativos seguros com boro, } \\
\text { sem arseniato e cromo - dimensão } \\
\text { ambiental/social } \\
\text { Tecnologias para adesivos e pinturas livres de } \\
\text { emissões - especialmente para chapas } \\
\text { (formaldeídos) e esmaltes - dimensão } \\
\text { ambiental/social }\end{array}$ \\
\hline $\begin{array}{l}\text { Oferta de madeira } \\
\text { Redução da disponibilidade de madeiras } \\
\text { tropicais } \\
\text { Redução da disponibilidade de florestas } \\
\text { temperadas naturais } \\
\text { Aumento da disponibilidade dos plantios de } \\
\text { madeiras leves }\end{array}$ & $\begin{array}{l}\text { Uso de materiais de construção alternativos e } \\
\text { desenvolvimento de tecnologias aptas para o } \\
\text { uso de materiais de matéria-prima de baixa } \\
\text { qualidade e produtos de alta qualidade (casca, } \\
\text { baixa densidade, madeira com nós, galhos etc) - } \\
\text { dimensão ambiental } \\
\text { Uso mais seletivo de recursos escassos, mais } \\
\text { reuso e reciclagem - dimensão } \\
\text { ambiental/econômica } \\
\text { Tecnologias que permitam a continuidade da } \\
\text { oferta do recurso, como laminados, madeiras } \\
\text { menos nobres e construções ocas - dimensão } \\
\text { ambiental/econômica } \\
\text { Falta de disponibilidade de algumas espécies de } \\
\text { madeira vão requerer tecnologias de imitação - } \\
\text { dimensão cultural }\end{array}$ \\
\hline
\end{tabular}


continuação...

\begin{tabular}{|c|c|}
\hline implicação nos produtos de madeira & implicações na tecnologia de processamento da madeira \\
\hline $\begin{array}{l}\text { Substitutos da madeira } \\
\text { Aumento da competição na indústria de } \\
\text { edificações } \\
\text { Aumento da mistura de componentes nos } \\
\text { sistemas construtivos } \\
\text { Baixa manutenção, produtos de fácil cuidado }\end{array}$ & $\begin{array}{l}\text { Tecnologias que permitem a combinação de } \\
\text { materiais - e guias, manuais, padrões e sistemas } \\
\text { de fixação eficientes que independem dos } \\
\text { materiais - dimensão ambiental }\end{array}$ \\
\hline $\begin{array}{l}\text { Sistemas construtivos } \\
\text { Produção sem resíduos } \\
\text { Habitação pré-fabricada } \\
\text { Padronização do projeto, técnicas de construção } \\
\text { rápidas, sistemas modulares } \\
\text { Uso de produtos de madeira em produção de } \\
\text { habitação em escala }\end{array}$ & $\begin{array}{l}\text { Produção e montagem just-in-time, com corte } \\
\text { otimizado de madeira em componentes para } \\
\text { produção sem resíduos - dimensão } \\
\text { ambiental/econômica } \\
\text { Dependência de tecnologia de informação para } \\
\text { um ambiente de construção e crescimento e } \\
\text { maior cooperação na indústria da construção, } \\
\text { para fornecer soluções inovadoras e de custo } \\
\text { eficiente - dimensão política }\end{array}$ \\
\hline
\end{tabular}

Quadro 23. Implicações para a indústria de produtos de madeira. fonte: traduzido de Bayne et al (2002)

\subsubsection{Processo de construção (pré-fabricação e montagem)}

A construção em madeira pode ter todas as suas operações realizadas in loco, mas também podem ser realizadas em um ambiente à parte cabendo somente à operação de montagem ser realizada no local. Existem ainda outras categorias para definição do grau de industrialização, mas por serem menos comuns, não são abordadas.

A pré-fabricação consiste numa produção seriada de componentes antes da montagem em canteiro de obras. Esse processo pode ter diferentes graus de industrialização (MARTUCCI, 1990):

- não-industrializados: artesanal e tradicional;

- semi-industrializado: tradicional racionalizado e pré-fabricado parcialmente;

- industrializado: pré-fabricado totalmente.

A definição do grau de industrialização de um processo construtivo depende da disponibilidade dos recursos financeiros e humanos, que por sua vez definem a quantidade e o tipo de materiais, equipamentos, tamanho e grau de envolvimento da assessoria técnica e a quantidade de mão-de-obra a ser contratada, de acordo com os dados apresentados em 
Arruda e Ino (2002). Outro fator que também interfere nessa definição é a quantidade de componentes a serem fabricados.

Quanto maior o grau de industrialização, maior será o nível de detalhamento requerido no projeto executivo. A pré-fabricação pode envolver componentes (painéis-parede, painéispiso, tesouras, pórticos, esquadrias e outras estruturas) (Figura 17) até células ou ainda unidades habitacionais inteiras.

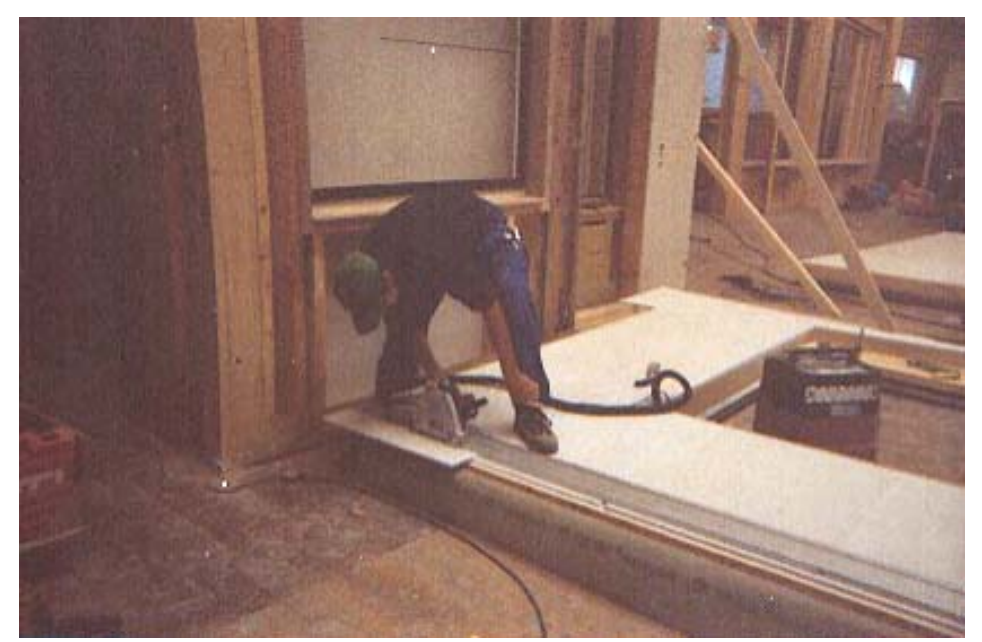

Figura 17. Pré-fabricação de componente painel parede de madeira e gesso acartonado. fonte: do autor

As variáveis de racionalização, que nesse caso, visam a redução de custos e de perdas para a etapa de produção propostas por Galinari e Ino (2004) são:

Racionalização no uso de equipamentos e ferramentas:

- Utilização de ferramentas e equipamentos de fácil manuseio, e popularmente conhecidas;

- Menor utilização de andaimes, escadas e equipamentos especiais.

- Menor utilização de equipamentos e ferramentas por subsistema.

Racionalização das atividades de execução:

- Maior simplicidade dos procedimentos de pré-fabricação e montagem;

- Maior pré-fabricação dos elementos construtivos;

- Maior adequação do peso e dimensão das peças/ elementos construtivos ao transporte e montagem manual; 
- Menor quantidade de atividades de montagem;

- Realização independente de tarefas na montagem;

- Possibilidade de repetição de operações sem destruição de peças.

Além da madeira beneficiada, nessa etapa há entrada de outros insumos como conectores metálicos, materiais plásticos, isolantes térmicos e acústicos e esquadrias.

Os produtos pré-fabricados podem então ser transportados para serem montados. $\mathrm{Na}$ montagem, os componentes são posicionados e conectados a outros componentes e a outros subsistemas da habitação, transparecendo nesse ponto os cuidados tomados no projeto das interfaces e na execução dos componentes. No contexto europeu foi verificado o uso comum de gruas tanto para proporcionar maior conforto aos trabalhadores quanto para agilizar a montagem, o que reverte em menores custos de mão-de-obra.

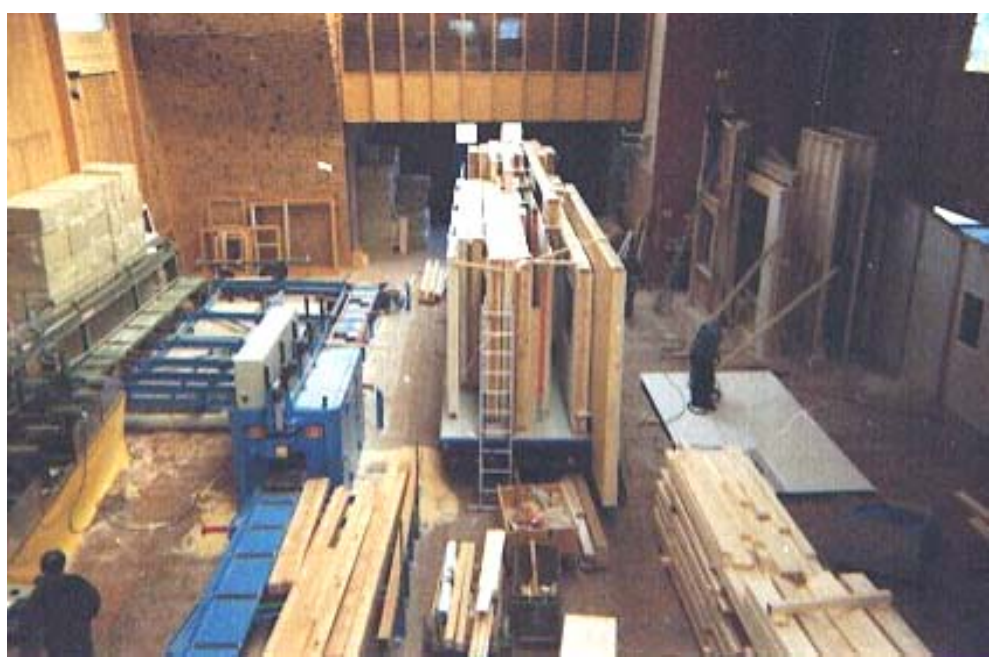

Figura 18. Preparação para transporte de componentes pré-fabricados de habitação em madeira. fonte: do autor

No caso da habitação em madeira, são identificados dois tipos de habitação individual: a casa para as classes mais altas e a casa demandada pela classe mais pobre (urbanas e rurais). No segundo caso, o proprietário se encarrega de todo o processo de projeto e construção da casa com a ajuda de terceiros - a autoconstrução. Para esse tipo de processo, o pinus apresenta características favoráveis à sua utilização - maior trabalhabilidade, leveza e menor propensão a defeitos de secagem (Ferguson e Dargavel, 1978) razão da dominação do mercado de estruturas para habitação na Austrália. 
Para a produção em escala em contextos de países em desenvolvimento, o HABYTED, observa a industrialização como um processo que pode viabilizar a alta produção com eficiente utilização de recursos e bom controle de qualidade, mas também reconhece a sensibilidade desse modelo, visto as interrupções de vários programas habitacionais, a monotonia decorrente da padronização e custos pouco acessíveis (SERRANO, 1993, p.29). O autor analisa boa parte dos problemas como resultantes da transferência literal de tecnologia dos países desenvolvidos, onde geralmente os custos de mão-de-obra são altos e que se justifica a industrialização. A produção em escala, experimentada em Cuiabá, na parceria entre o GHab (EESC/ USP- UFSCar) e a Prefeitura Municipal e em Campos do Jordão, mostram a razão da preocupação, uma vez que os programas foram interrompidos na transição entre governos municipais. Para a sustentabilidade política, essas experiências indicam a necessidade da existência de um engajamento da população diretamente atingida e principalmente uma estrutura auto-suficiente, independente das esferas governamentais, para que não possam ser atingidas nas trocas de governo.

No processo de montagem, o CWC aponta as características de construção a seco e a menor produção de resíduos no canteiro como vantagens dos sistemas construtivos em madeira em relação aos processos de construção tradicionais. Segundo essa análise, o maior impacto na etapa de montagem é o causado pelo consumo de energia usada para transporte, pelos equipamentos de construção e os resíduos sólidos gerados durante a construção (CWC, 1996).

A fragilidade das empresas que produzem e comercializam habitações pré-fabricadas em madeira se deve a alguns fatores impeditivos de mudança, apontados por Voinson e Castagné (1988):

- a pesquisa não é considerada importante dentro das empresas;

- falta de informação sobre o que ocorre no Brasil nos países desenvolvidos;

- a falta de concorrência com produtos importados em razão da baixa capacidade de compra é a origem de uma tendência de desenvolvimento muito fraca na qualidade dos produtos.

Num mercado bastante restrito, onde $90 \%$ das compras são para usuários que já possuem uma casa de alvenaria e buscam uma segunda casa para pequenas temporadas (VOINSON e CASTAGNÉ, 1988), ao invés das empresas se estruturarem para a criação de produtos 
competitivos, essas acabam mudando de atividade, não apresentando práticas eficazes para enfrentar os concorrentes.

\subsubsection{Uso e manutenção}

A qualidade das edificações não está restrita à qualidade dos processos de produção somente e por isso os hábitos de uso, limpeza e reformas (pinturas, substituição de peças) dos usuários influenciam, conjuntamente com a exposição às intempéries, as condições de conforto ambiental e durabilidade da habitação. Várias questões da sustentabilidade são relacionadas a essas últimas fases do ciclo de vida da habitação em madeira, referentes ao usuário, principal agente nesse processo.

A abordagem nessa etapa é geralmente feita através das avaliações de desempenho (estrutural, durabilidade, conforto ambiental) e nas avaliações pós-ocupação. Uma experiência de avaliação de conforto térmico em habitações de interesse social em madeira (nativas e de plantios florestais) foi realizada por Silva e Basso. Os resultados mostram o baixo desempenho das habitações, "todas com horas de desconforto em mais de 30\% do dia, tanto no inverno como no verão, além de descumprirem o código de obras municipal e as recomendações do projeto da norma". Os autores comentam a relação desses resultados com a baixa qualidade dos projetos, resultado da atuação de projetistas não capacitados para lidar com a madeira (e com as questões de conforto), "da falta de rigor construtivo e a preocupação maior de reduzir custo mesmo que em detrimento da qualidade" (SILVA e BASSO, 2001, p.218).

Arakaki (2000) também observa esse e outros dados quando avalia a durabilidade das habitações em madeira de rejeito comercial produzidas no Bairro Pedra 90, realizada pela parceria GHab- EESC.USP-UFSCar/ Prefeitura Municipal de Cuiabá. Decorridos 3 anos da construção, os subsistemas que apresentaram desempenho insatisfatório foram as esquadrias (segurança à intrusão e estanqueidade) e vedação (frestas e manchas). Por sua vez, o sistema construtivo, de painéis portantes, associados a estruturas de pilar-viga, facilitou a execução das manutenções necessárias sem comprometer a utilização da habitação.

A autora relaciona o baixo desempenho desses subsistemas à falta de uma adequada retroalimentação do projeto, após a construção dos protótipos, a entrega das unidades não 
acabadas para os moradores e as incompatibilidades entre a alta velocidade de produção e o controle de qualidade.

É criticada a expectativa de ganho político com o projeto, quando o critério "quantidade" foi priorizado em relação à "qualidade" nas alterações realizadas no projeto original das habitações.

Como a manutenção da habitação depende das observações do usuário, a adequação à cultura de construção também está relacionada a essa etapa. É importante que o morador de uma habitação em madeira seja capaz de compreender os possíveis problemas da habitação e buscar soluções adequadas, de maneira a garantir o melhor uso possível, a vida útil estendida da habitação e a correta destinação dos resíduos após o uso.

Por isso, a necessidade de mais estudos sobre avaliação pós-ocupação e estudos mais específicos sobre habitabilidade (elementos de desempenho e outros fatores que influenciam o comportamento dos usuários) e sobre fatores determinantes da satisfação do usuário em habitações em madeira, de forma a melhor caracterizar os aspectos culturais que influenciam a aceitação ou rejeição dos usuários sobre esse produto.

Viana (2003) relaciona a durabilidade de um conjunto de habitações em madeira de Itararé e a percepção dos respectivos moradores quanto aos problemas de desempenho. Nessa pesquisa foi verificada a alta incidência de sistemas construtivos simples (pilar-viga com fechamento em tábua e mata junta, na maioria dos casos), ocupados por famílias de baixa renda, que revelaram a insatisfação com as próprias habitações. Os principais defeitos identificados são o apodrecimento, manchas superficiais, frestas, rachaduras, perfurações e nós soltos.

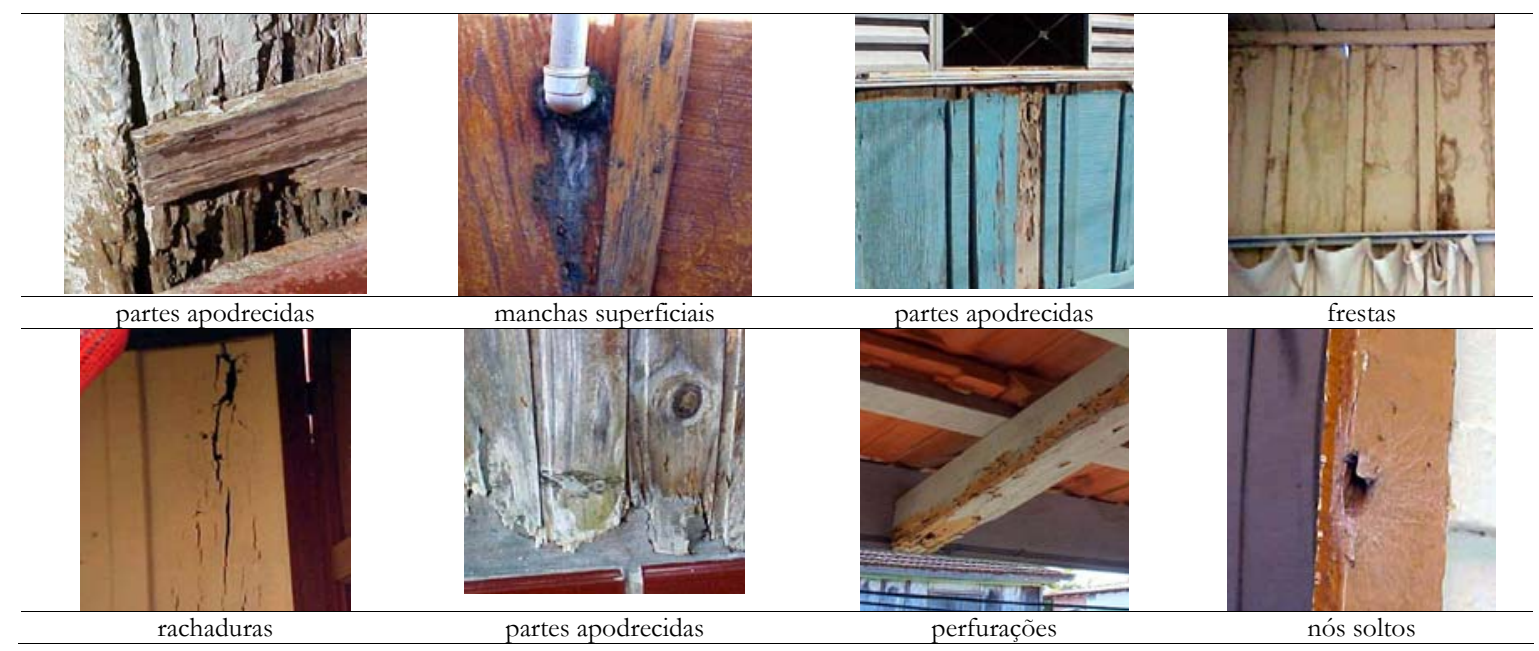

Figura 19. Problemas de durabilidade identificados nas habitações de madeira em Itararé fonte: Viana (2003) 


\subsubsection{Processo de desmontagem, reaproveitamento, reuso e reciclagem}

A introdução do conceito de sustentabilidade na cadeia produtiva requer a mudança do tradicional pensamento linear de "deposição de resíduos" do final da cadeia para um pensamento cíclico, de re-introdução do material, na forma de reaproveitamento, reuso ou reciclagem.

Isso exige uma preparação que antecede algumas etapas na cadeia produtiva, até o processo de projeto. As escolhas de material e de técnicas construtivas determinam a viabilidade de qualquer uma dessas formas de reutilizar o material. O detalhamento construtivo, chamado em CIB (1999) de "aptidão para desmontagem” também é outro fator determinante.

A habitação em madeira, quando utiliza componentes maciços, caracteristicamente permite a desmontagem, a re-montagem ou aproveitamento de peças, dependendo da concepção das conexões do sistema construtivo. A degradação natural também é outro atributo favorável à sustentabilidade ambiental desse material.

Entretanto, esses atributos são ameaçados com o acúmulo de conseqüências dos processos antecessores. Sperb e Sattler (2001) analisam cinco diferentes tipologias habitacionais quanto aos impactos ambientais. $\mathrm{O}$ atendimento à maior parte dos requisitos de adequação ambiental analisados - grau de exploração de recursos naturais, os gastos energéticos durante a manufatura e transporte dos materiais de construção desde seu produtor até o local da obra - nos quais o desempenho da madeira é adequado não a isenta da necessidade de atendimento ao último requisito, da reciclabilidade. Dentre todos os materiais analisados, a madeira tratada com preservativos tóxicos e o cimento-amianto são os únicos que não oferecem soluções práticas de reciclagem.

Com o tratamento, a degradabilidade natural é comprometida e a opção da queima exige temperatura e ambiente adequados para evitar a liberação de componentes tóxicos no ar, demandando trabalho de controle e fiscalização.

É importante que o usuário ou o responsável pela desmontagem possa reconhecer a madeira tratada quimicamente com produtos tóxicos para a adequada separação.

Além dos produtos químicos do tratamento, outros contaminantes podem estar presentes (pregos, tintas, peças metálicas e plásticas), dificultando a reutilização ou aproveitamento para outros fins. A amenização dessa situação requer um cuidado maior durante o projeto e produção dos componentes da edificação. 
Num estudo de reaproveitamento de resíduos de madeira urbanos, não específico de habitações, permitiu observar a diversidade de contaminantes presentes, limitando muito as possibilidades de aproveitamento estudadas (YUBA et al, 2000). A trituração para produção de composto e cobertura de jardim foi identificada como a mais adequada, em virtude da presença de muitos contaminantes e de variados tipos.

A restrição do uso de produtos tóxicos somente a componentes essenciais, reduzindo a quantidade de madeira tratada na habitação também é uma das formas consideradas para aumentar o grau de sustentabilidade da cadeia produtiva, pois considera a característica da degradabilidade natural da madeira, com reduzido impacto ambiental.

\subsection{Conclusões}

Analisando os dados obtidos na caracterização dos processos da cadeia produtiva da habitação em madeira de plantios florestais, evidencia-se que poucas pesquisas se destinam a trabalhar com a cadeia produtiva como um todo. A caracterização dos processos na cadeia produtiva da habitação em madeira de plantios florestais mostra:

- o desequilíbrio do grau de desenvolvimento das pesquisas sobre os processos iniciais (produção de matéria-prima, fabricação) e finais (uso, manutenção e desmontagem) da cadeia produtiva da habitação em madeira de plantios florestais, retratado pelo foco das ações de pesquisa e desenvolvimento levantados nessa caracterização;

- o predomínio da visão compartimentada (dentro dos processos) em detrimento da visão mais abrangente (da cadeia produtiva), não favorecendo uma abordagem mais aprofundada da conexão das questões entre processos;

- o recorte preponderantemente tecnológico-ambiental da realidade, criando, em muitos casos, a percepção de que é possível priorizar tais questões, seja atribuindo maior valor ou denominando-as "chave" para as questões de outras dimensões da sustentabilidade.

Percebe-se também que o controle das variáveis nos trabalhos de cunho experimental (em laboratório) é o fator que possibilita maior objetividade na execução das pesquisas, sendo uma das características que ressaltam na diferenciação desses trabalhos de outros que têm a realidade como objeto empírico. Ainda assim, na transferência de tecnologia, os resultados desse tipo de pesquisa nem sempre são aplicáveis pelos agentes da cadeia produtiva, possivelmente influenciada pelo excessivo recorte da realidade estudada e agravada pela desarticulação do setor. 
Esse fator determina a percepção na presente pesquisa de que, além do desenvolvimento tecnológico, a cadeia produtiva da habitação em madeira de plantios florestais depende de um aporte de conhecimento e ações de outras dimensões, que sejam simultâneos. Nota-se, por exemplo, a dificuldade de implantar programas de melhoramento de florestas num contexto de ausência de políticas de produção florestal ou ainda a ineficiência do trabalho de desenvolvimento de novos produtos num cenário de crise econômica e mortalidade dos empreendimentos, principalmente os de pequeno porte.

Compreendendo a necessidade de uma forma de abordagem das questões macro, que são imperceptíveis na escala micro, esta pesquisa, por essa razão, vinculará a cadeia produtiva com o conceito de sustentabilidade e seus princípios, na perspectiva de suprir, ou de pelo menos anunciar, as lacunas para um processo de desenvolvimento da cadeia produtiva que tenda a ser virtuoso.

Uma abordagem mais abrangente, que relacione os processos da cadeia produtiva só é observada para a as questões técnicas, sendo para tanto exploradas as relações de antecedência e conseqüência nos dados apresentados pelas pesquisas. 


\section{CAṔTULIO 3}

\section{POSTURAS FRENTE À INDISSOCIABILIDADE DAS DIMENSÕES NAS VISÕES DE SUSTENTABUIIDADE}

Além de melhor definir o escopo das dimensões menos trabalhadas, tema do Capítulo 2, a construção sustentável demanda também o trabalho com o caráter de indissociabilidade das dimensões do conceito de sustentabilidade.

A natureza das questões de sustentabilidade pode ser entendida como uma complexa rede de questões interconectadas, que congrega aspectos mais objetivos (como a maior parte das questões ambientais) e outros aspectos que têm um forte caráter subjetivo, resultando na aumentada dificuldade de obtenção de dados absolutos. Tal complexidade, para ser considerada na tomada de decisões, implica na busca e utilização de procedimentos o mais transparente possível e a obtenção de dados que possam ser mais facilmente compreendidos.

Lyle (1994), ao analisar o desempenho da ciência no estudo das questões ambientais, salienta a dificuldade de lidar com muitas variáveis ao mesmo tempo. "Essa é a razão de muitas pesquisas lidarem com questões pequenas, especialmente os aspectos essencialmente lineares dos processos da natureza em níveis celulares e moleculares". Nesses níveis é possível produzir dados quantitativos, ainda que com um certo grau de incerteza, mas à medida que a escala do processo analisado aumenta, somente dados qualitativos podem descrever a realidade. A elaboração de cálculos matemáticos sofisticados, estimativas e previsões precisamente quantificadas para a "solução" de questões complexas também têm limitações e esbarram na disponibilidade de dados (alguns até inviáveis) e sua imprecisão. Lyle analisa que a focalização tem tirado a atenção do funcionamento altamente integrado do ambiente como um todo.

A mudança para uma visão mais plural e inter-relacionada surge com a necessidade de reproduzir com maior fidelidade os problemas da realidade de maneira a permitir a efetiva condução das soluções, reduzindo cada vez 
mais o "esquema mecanicista das séries causais isoláveis e do tratamento por partes" (BERTALANFFY, 1977, p.28).

Para estudar a indissociabilidade das dimensões na sustentabilidade da cadeia produtiva da habitação em madeira de plantios florestais, serão abordados conceitos que contribuem para a visão mais abrangente e as pesquisas atualmente realizadas, na forma principal de métodos de avaliação de sustentabilidade, que em tese estão à frente na operacionalização do conceito, englobando as características requeridas da sustentabilidade (progressivo, holístico e histórico), identificadas por Silva e Shimbo (2001).

\subsection{Contribuições conceituais e metodológicas de abordagens mais ampliadas}

Savory avalia que "a biosfera incluindo sua estabilidade biológica, só pode ser entendida pela observação de suas inter-relações dinâmicas".

"Se se tenta isolar alguma parte, nem o que foi isolado, nem o que ficou, representam mais o que existia antes, quando tudo era um conjunto só. Sistemas (holons), e não coisas isoladas, constituem a estrutura primária da natureza. Mas os sistemas não são formados por um conjunto de partes isoladas, eles constituem arranjos. A natureza não é formada por partes individuais, porém por sistemas interligados” (SAVORY apud LIMA, 1993).

Essa forma de abordagem, preconizada pela sustentabilidade para aplicação não só nos sistemas naturais, é desenvolvida com a teoria geral dos sistemas, por Ludwig von Bertalanffy. "O sistema ou complexidade organizada pode ser definido pela existência de 'fortes interações'(Rapoport) ou de interações 'não triviais' (Simon), isto é, não lineares” (BERTALANFFY, 1977, pg. 38).

Coyle (1996, p.4) complementa, dizendo que se trata de "um conjunto de partes que interagem de um modo que o todo tem propriedades que não são evidentes nas partes". Mais pragmaticamente, seria "um conjunto de partes organizadas para um propósito".

Compreensão e previsão são proporcionadas pela teoria dos sistemas na aplicação prática em entidades que são "parcialmente imateriais e altamente heterogêneas" (negócios, governo, política internacional) (BERTALANFFY, 1977, pg. 261).

Outro conceito de relevância para apoiar a sustentabilidade é o system dynamics, base para o desenvolvimento de ferramentas de simulação. O system dynamics foi criado por Jay 
Forrester (BLACK, CARLILE e REPENNING, 2000; COYLE, 1996) para auxiliar na tomada de decisões e permite entender como e porque as variáveis mudam, simulando uma variedade de cenários que podem mostrar a dimensão do comportamento das variáveis assim como o equilíbrio do sistema analisado.

"[O]s sistemas sócio-econômicos geralmente contêm significativas nãolinearidades e não podem ser representadas como objetos separáveis do seu ambiente. Por causa de suas não-linearidades, retroalimentações positivas (que resultam em crescimento) e grande escala, os problemas sócioeconômicos são simplesmente intangíveis para a rigorosa matemática da teoria do controle" (COYLE, 1996, p. 347).

Sistemas com muitos processos de retroalimentação, atrasos e eventos não lineares ainda definem a "complexidade dinâmica" (BREHMER, FUNKE, STERMAN apud BLACK, CARLILE e REPENNING, 2000).

Apesar de ter origem no gerenciamento de negócios, Coyle diz que a teoria de system dynamics é aplicável a problemas sociais, assim como em questões de alta complexidade. Dentre a diversidade de aplicações (degradação das cidades, as mudanças no comportamento social, os ciclos da expansão/ recessão econômica e crescimento/ queda de nações), Yonenaga (2001) aplicou o conceito no gerenciamento de plantios florestais, na tomada de decisões sobre a melhor época para a realização do corte das toras.

O system dynamics opera conforme o esquema do loop de retroalimentação, seu elemento central. O comportamento dinâmico do sistema é determinado pelo conjunto de informações, ações e conseqüências que, a partir de um determinado estado, derivado de escolhas, evolui com a agregação de conhecimento, passando então por novas escolhas, que por sua vez, determinam novos estados e assim, sucessivamente. " $\mathrm{D}_{\mathrm{x}}$ " simboliza os diferentes tempos demandados entre cada processo (Figura 20). 


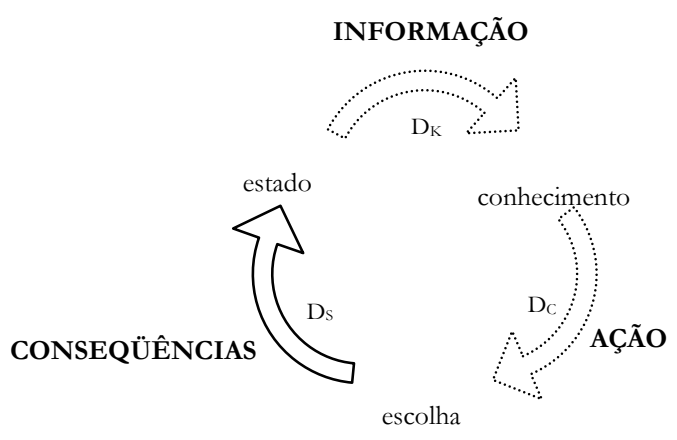

Figura 20. O paradigma da informação/ ação/ conseqüência do system dynamics. fonte: traduzido de Coyle (1996)

O uso dessa ferramenta tem por objetivo "complementar a mente humana - identificando inter-relações entre aspectos importantes de qualquer sistema - e compensando a falta de capacidade do cérebro humano de intuir o comportamento dinâmico resultante dessas inter-relações ao longo do tempo".

Para reforçar, Black, Carlile e Repenning ainda citam pesquisas que mostram a dificuldade de intuição de resultados de interações dinâmicas dos humanos, erros de percepção de causas e efeitos e experimentos que mostram à medida que a complexidade dinâmica de um sistema cresce, o desempenho dos que tomam as decisões diminuem (DIEHL e STERMAN; PAICH e STERMAN apud BLACK, CARLILE e REPENNING, 2000). Os erros de percepção de retroalimentação ocorrem porque nossos mapas cognitivos são muito simplificados tendendo a omitir elementos da complexidade dinâmica e porque não somos capazes de usar tais mapas para inferir a dinâmica do sistema (STERMAN apud BLACK, CARLILE e REPENNING, 2000).

A abordagem estruturada para analisar um system dynamics é composta de 5 estágios: 


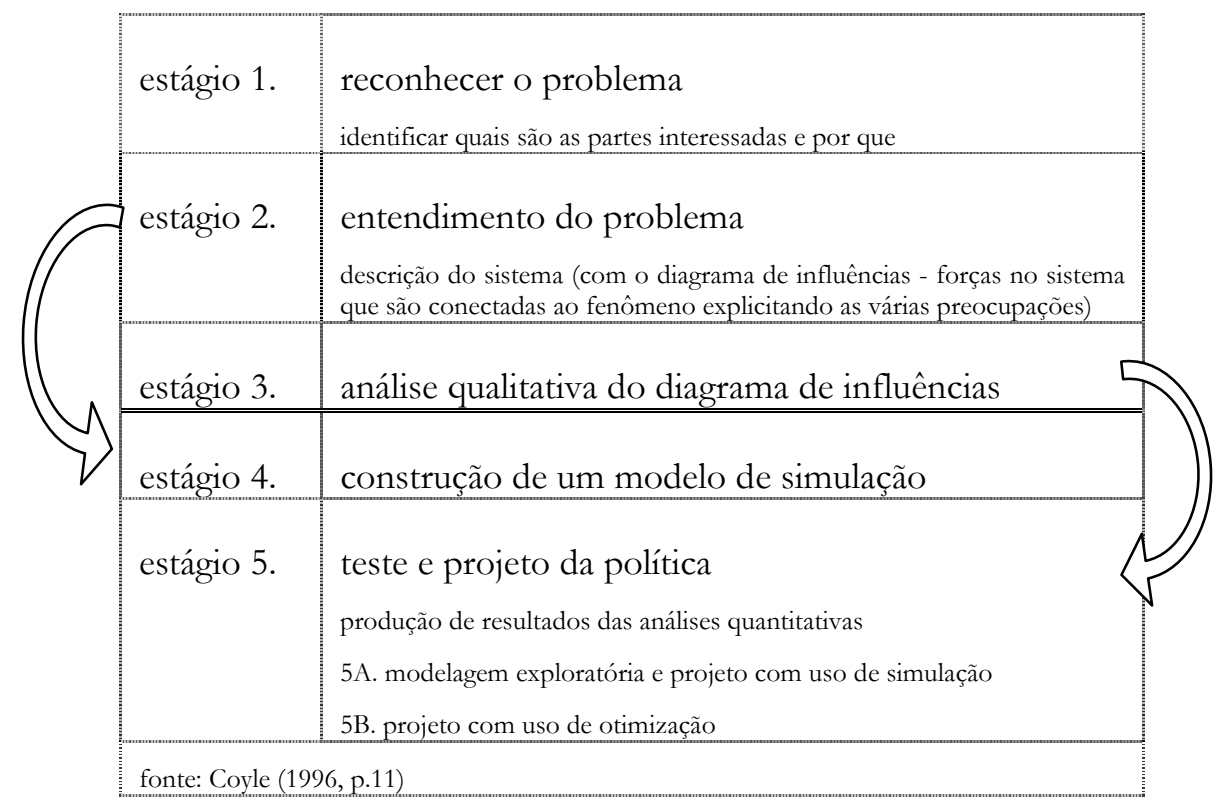

Figura 21. Estrutura da abordagem do system dynamics. fonte: traduzido de Coyle (1996)

A partir do estágio 3 o problema já pode ser solucionado, o que explica a quebra para o estágio 4. Dados do entendimento do problema (estágio 2) são utilizados na construção do modelo de simulação (estágio 4), que também ocorre entre os estágios 3 e 5. Para enfatizar as relações entre os estágios de trabalho e os seus resultados, Coyle mostra a seguinte figura. Os fluxos 5A e 5B mostram que os resultados dessa análise são os insights e idéias, assim como o que o autor chama de "políticas robustas", ou fortes.

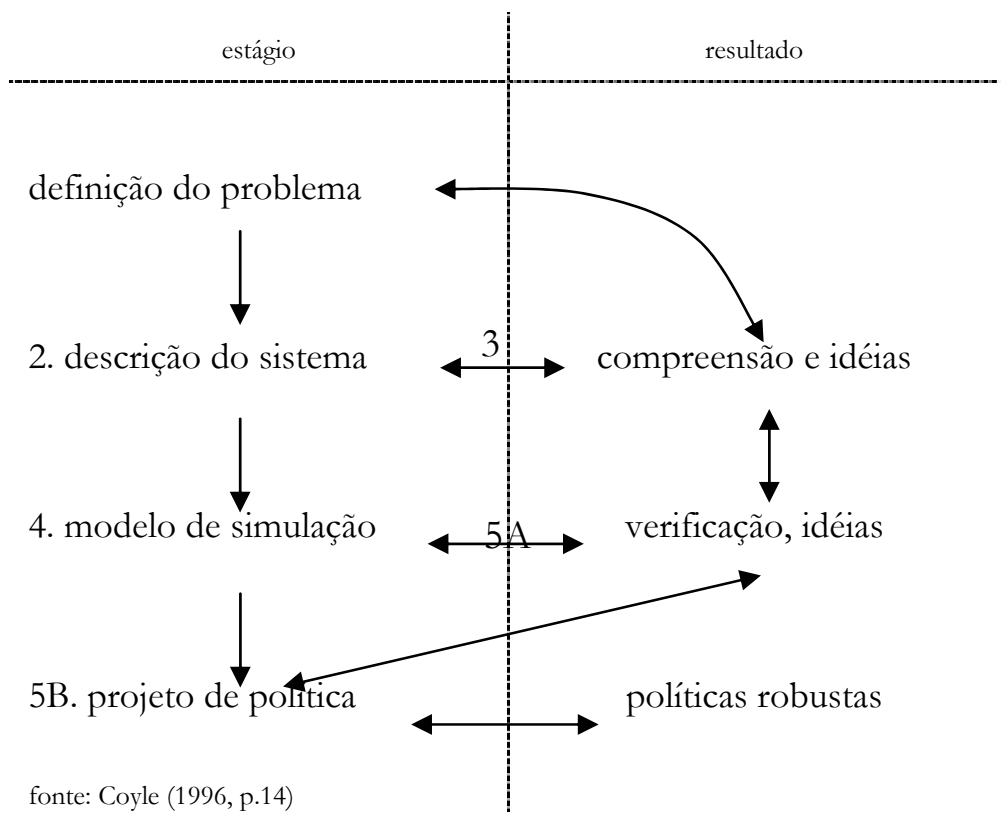

Figura 22. O processo de um system dynamics fonte: traduzido de Coyle (1996) 
Coyle examina a possibilidade de simular e controlar os sistemas sócio-econômicos nos mesmos padrões dos sistemas das áreas de exatas, por poderem ser analisados com os mecanismos de retroalimentação e porque a qualidade de uma política e a forma como se estrutura são fatores que produzem bons ou maus desempenhos.

A abordagem de system dynamics também é considerada como um dos métodos para avaliar a sustentabilidade na construção civil pelo Bequest Toolkit (MACOUN e CURWELL, 2001). A visão de ciclo de vida, proporcionada pela LCA $^{34}$ também é uma significativa contribuição para a visão de sustentabilidade. É uma abordagem de gerenciamento para reduzir o impacto de um produto, embalagem ou atividade que impacta a saúde humana ou o ambiente. Ele examina cada estágio do ciclo de vida de produtos manufaturados da extração de matéria prima através da produção ou construção, distribuição, uso, manutenção, reparos e deposição ou reciclagem (UNEP, 2001, HENN e FAVA, 1994, p. $542)$.

Até a década de 80, o foco era o consumo de energia. Com o crescimento das preocupações ambientais, sobre a deposição de resíduos sólidos, o foco mudou para além da energia, questões de consumo de recursos e emissões potenciais na forma de resíduos.

Mais recentemente a ênfase é a utilização do LCA para prevenir a poluição, proativamente. Mas isso tem trazido controvérsias sobre a utilização inapropriada para promover selos ambientais. Os estágios do ciclo de vida analisados são (HENN e FAVA, 1994, p 626):

- Extração de matéria prima e conversão;

- Processamento (fabricação, montagem e acabamento);

- Operação (instalação, consumo de recursos, manutenção, reparos);

- Pós-uso (deposição, reciclagem e reuso). 


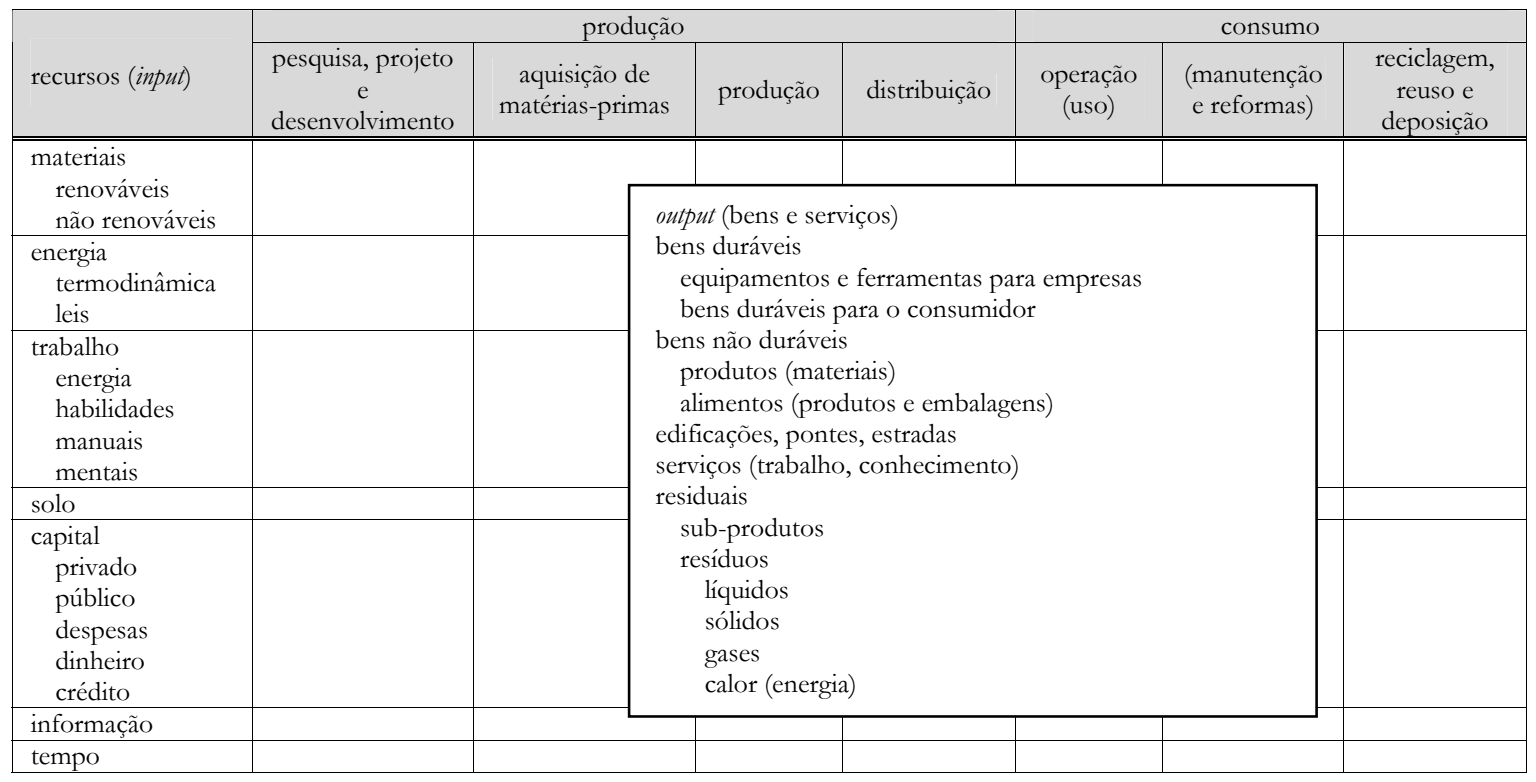

Quadro 24. Análises de sistemas de ciclo de vida. fonte: traduzido de Henn e Fava (1994, p. 593)

Os benefícios da abordagem do ciclo de vida são (UNEP, 2001):

- para indústrias: ambientais, de saúde e segurança, tecnológicos e de gerenciamento, melhoria da imagem da empresa;

- para os governos: benefícios ambientais à sociedade e exemplo de uso e disseminação da responsabilidade global no apoio a iniciativas de implementação de análises de ciclo de vida;

- para os consumidores: informação para orientar o consumo de produtos e dar a oportunidade para o seu envolvimento em estratégias conjuntamente com as empresas e outros interessados, para aumentar a sustentabilidade.

As prioridades para o LCA nos países de rápido crescimento e em desenvolvimento são (KOHLER e MOFFAT'T, 2003):

- utilizar o LCA como ferramenta para definir as prioridades na legislação;

- auxiliar na determinação de taxas e impostos;

- gerenciar a velocidade das mudanças (o LCA valoriza estilos de construção e tecnologias resistentes e duradouras, reduzindo perdas culturais irreversíveis);

- reduzir impactos associados com o desperdício de material incorporado no ambiente construído; 
- definir metas nas áreas mais receptivas para as iniciativas regionais e nacionais e apoiar melhoramentos na inovação nas indústrias e na proteção ambiental;

- enfatizar os problemas gerados pela introdução de substâncias tóxicas.

Diante dos altos custos para a execução desse tipo de análise, os autores dizem que a sua evolução se dará quando o processo for simplificado, a ponto de aplicar o conhecimento gerado pelas pesquisas durante o projeto das edificações. Nos países em desenvolvimento, o LCA pode permitir fixar estratégias para uso otimizado dos recursos escassos, sendo citados o cimento, vidro e metais, assim como combustíveis para transporte.

Henn e Fava entre outros autores criticam a visão linear dada pelas primeiras noções de ciclo de vida, que na realidade constituíam fluxos e propõem a visão de ciclo, substituindo o conceito de berço ao túmulo por berço ao berço. Os autores dizem que mesmo essa denominação não é a mais apropriada, uma vez que implica num renascimento. "Não é a vida após a morte, ou no lugar da morte, mas a vida antes do berço”.

Na visão de Munda, Nijkamp e Rietveld (1994) as questões ambientais são provenientes de uma desconexão artificialmente criada entre recursos naturais e ambiente, que faz com que a primeira seja vista como um bem a ser explorado e a segunda como um bem a ser conservado. Essa percepção embasa a prática da valorização dos lucros em detrimento da melhoria do desempenho ambiental, difundindo a prática do cumprimento de requisitos mínimos de proteção ambiental. Os conflitos com os quais a economia lida são a eficiência na alocação dos recursos, a equidade na sua distribuição e a definição de uma escala ótima.

A reflexão desses autores mostra que geralmente os preços definem a eficiência e a política de distribuição de renda, a equidade; e que o mercado não consegue achar uma escala ótima nem tampouco uma distribuição ótima. Por isso consideram a necessidade de um incremento de critérios éticos para melhorar a distribuição de renda e critérios ecológicos para melhorar a eficiência.

Se a divisão "ambiente - recursos" é suprimida, o sistema econômico volta a desempenhar, como qualquer outro subsistema ecológico, o papel de um sistema dinâmico aberto de todo o ecossistema global finito. O crescimento do subsistema econômico, que implica na expansão humana, exploração dos recursos naturais e deposição de resíduos e poluentes, é limitado pelos impactos de suas ações no ambiente finito. Não apenas porque afeta o ambiente natural, mas também o nível e composição de bens e serviços (FOLKE apud 
MUNDA, NIJKAMP e RIETVELD, 1994). As interações entre as duas dimensões são representados simplificadamente na estilização da Figura 23:

\begin{tabular}{|c|c|c|}
\hline & economia & ambiente \\
\hline \hline economia & 1 & 2 \\
\hline ambiente & 3 & 4 \\
\hline
\end{tabular}

1. interações intra-econômicas

2. impactos da economia sobre o ambiente

3. efeitos do ambiente sobre a economia

4. interações intra-ambientais

Figura 23. Interações ambiente - economia fonte: traduzido de Munda, Nijkamp e Rietveld (1994, p. 3)

Steer e Wade-Gery (1994) propõem como estratégia geral para o desenvolvimento sustentável:

- explorar as ligações positivas entre o crescimento econômico, eficiência e proteção ambiental;

- quebrar as ligações negativas entre o crescimento econômico e a degradação ambiental;

- superar obstáculos políticos e institucionais para a adoção dessas duas medidas.

Mais detalhadamente, Van der Bergh e Nijkamp apud Munda, Nijkamp e Rietveld (1994) propõem que a operacionalização da sustentabilidade no gerenciamento ambiental trabalhe com os seguintes critérios:

- consideração das relações existentes entre as dimensões econômica e ambiental, já que as políticas ambientais podem visar diferentes objetivos: a conservação dos recursos, o seu máximo aproveitamento ou um objetivo misto; com possibilidade de utilização de ferramentas de simulação para permitir a compreensão da complexidade da realidade;

- os usos múltiplos do recurso explorado para atender a diversos propósitos econômicos e sociais;

- as relações os conflitos de interesse existentes entre os vários níveis de abordagem;

- a incerteza, ambigüidade, imprevisibilidade e indistinção geradas pela introdução de informações qualitativas presentes principalmente nas questões sociais, difíceis de serem inseridas nos métodos tradicionais. 
A ambigüidade da informação se deve à forma de expressão, baseado na linguagem diária, naturalmente imprecisa, com questões de sintaxe e semântica inerentes. Ao invés de transformá-los em dados numéricos, questiona-se a possibilidade de trabalhar com representações lingüísticas, causando menos distorções sobre a realidade analisada.

Metodologicamente, reunir e equilibrar informações com características diferentes é a maior dificuldade da avaliação integrada. Um bom exame requer:

- a superação das diferenças na escala:

○ temporal: comparado com a ecologia, a economia analisa efeitos a curto e médio prazos;

○ espacial: a escala espacial de muitas variáveis ecológicas é às vezes pequena, enquanto que a escala de muitas variáveis econômicas são maiores;

○ medida das variáveis.

- determinar o grau de complexidade da avaliação, que depende da natureza do problema, o tempo e o conhecimento disponíveis e o contexto organizacional.

É freqüente que muitas avaliações justifiquem a ausência da pluridimensionalidade em função dos fatores tempo e conhecimento disponíveis.

\subsection{Ferramentas para promoção da interação entre dimensões da sustentabilidade}

Também buscando uma maior aproximação da realidade, a avaliação multi-critérios é utilizada como ferramenta de modelagem por Munda, Nijkamp e Rietveld (1994). Os autores a utilizam para discutir as pressões econômicas e ambientais e suas interações na necessária legislação sobre o uso dos recursos naturais.

A possibilidade de lidar de forma flexível com "critérios conflitantes" e com os "efeitos qualitativos multidimensionais das decisões" é de interesse para o conceito de sustentabilidade. "As técnicas de avaliação multi-critérios não podem solucionar todos os conflitos, mas dão uma idéia maior da natureza dos conflitos através de informações sistemáticas possibilitando chegar a acordos [...] tornando uma situação complexa mais transparente para os decisores” (MUNDA, NIJKAMP e RIETVELD, 1994, p.7). 
Esses autores classificam 3 tipos de abordagem multi-critérios para informações qualitativas:

- Abordagens da teoria de utilidade: direta (utiliza os dados qualitativos) e indireta (transforma os dados qualitativos em quantitativos). O segundo tem a vantagem de incorporar também dados mistos;

- Abordagens outranking: para situações em que é suficiente apenas evidenciar a ordem de importância entre os critérios, sendo suficiente uma classificação ordinal;

- Avaliação multi-critérios em ambientes indistintos: um modelo de decisão fu₹æy (D) "é essencialmente caracterizado por um conjunto de funções dos agentes (F)", onde $\mathrm{D}=\{$ objetivos, alternativas exeqüíveis, obstáculos, parâmetros relevantes, preferências subjetivas do decisor, funções dos agentes\}. As funções dos agentes "podem ser definidas com base em um ou mais dos outros componentes do modelo e então o grau de indistinção do modelo pode variar de acordo".

O método proposto para a tomada de decisões em gerenciamento ambiental, é exemplificado pela matriz de impacto apresentada na Tabela 8, extraída do estudo de caso realizado pelos autores, sobre a escolha entre diferentes alternativas de uso do solo de uma região, a partir de uma dada situação atual (agricultura tradicional).

Tabela 8. Matriz de impacto furzy.

\begin{tabular}{|c|c|c|c|c|c|c|}
\hline \multirow[b]{2}{*}{ critérios de avaliação } & \multirow[b]{2}{*}{ unidades } & \multicolumn{5}{|c|}{ alternativas } \\
\hline & & $\begin{array}{c}\text { da maneira } \\
\text { como está (a) }\end{array}$ & $\begin{array}{l}\text { agricultura } \\
\text { otimizada (b) }\end{array}$ & alagamento (c) & $\begin{array}{l}\text { alaga/o parcial } \\
\text { e agricultura } \\
\text { tradicional (d) }\end{array}$ & $\begin{array}{c}\text { alaga/o parcial } \\
\text { e agricultura } \\
\text { otimizada (e) }\end{array}$ \\
\hline lucro bruto & lira italiana & 64.000 .000 & 159.000 .000 & $\sim 143.000 .000$ & $\sim 95.000 .000$ & $\sim 147.000 .000$ \\
\hline emprego & $\begin{array}{l}\text { homem/ } \\
\text { ano }\end{array}$ & 8 & 20 & 9 & 8 & 14 \\
\hline $\begin{array}{l}\text { atratividade para } \\
\text { turismo }\end{array}$ & lingüística & ruim & ruim & bom & moderado & moderado \\
\hline $\begin{array}{l}\text { atratividade para } \\
\text { recreação }\end{array}$ & lingüística & moderado & moderado & bom & moderado & moderado \\
\hline $\begin{array}{l}\text { equilíbrio } \\
\text { ecológico da } \\
\text { floresta a ser } \\
\text { preservada }\end{array}$ & lingüística & ruim & ruim & bom & bom & bom \\
\hline $\begin{array}{l}\text { risco de } \\
\text { ocorrência de } \\
\text { danos ecológicos }\end{array}$ & lingüística & moderado & ruim & bom & ruim & ruim \\
\hline
\end{tabular}


A análise econômico-ambiental desses cenários diz que não é possível apoiar a continuidade da situação atual (a). A situação (d), misto entre a agricultura tradicional e o alagamento também é uma opção fraca. A opção (c) tem mais pontos favoráveis do que a opção (b). Como é difícil comparar (e) com (b) e (c), a decisão é tomada em função da análise anterior, que diz que o alagamento é melhor do que a agricultura otimizada. Então, de um conjunto de cinco cenários, as opções viáveis com base nessas duas dimensões se resumem a duas.

Esse método comporta medidas quantitativas e qualitativas e mostra simplificadamente todas as análises feitas, dando condições para comparações entre cenários e uma visão mais sistêmica.

Ainda sobre o mesmo exemplo, além dessa matriz, outra é desenvolvida que mostra os impactos dos diferentes meios sobre diferentes grupos de renda/ interesse (Tabela 9), ressaltando o caráter da busca de soluções eqüitativas. As informações que a compõem não são precisas e o grau de incerteza sobre os impactos dos diferentes planos é alto. Os autores dizem que a avaliação foi feita com base em princípios heurísticos, pela interação com a população local e alguns especialistas.

Tabela 9. Avaliações fuzæy de impactos das diferentes meios de ação alternativos sobre os diferentes grupos de interesse

\begin{tabular}{|c|c|c|c|c|c|}
\hline \multirow[b]{2}{*}{ grupos de interesse } & \multicolumn{5}{|c|}{ alternativas } \\
\hline & $\begin{array}{c}\text { da maneira como } \\
\text { está (a) }\end{array}$ & $\begin{array}{l}\text { agricultura } \\
\text { otimizada (b) }\end{array}$ & alagamento (c) & $\begin{array}{l}\text { alagamento parcial } \\
\text { e agricultura } \\
\text { tradicional (d) } \\
\end{array}$ & $\begin{array}{c}\text { alagamento parcial } \\
\text { e agricultura } \\
\text { otimizada (e) } \\
\end{array}$ \\
\hline fazendeiros & bom & muito bom & muito ruim & ruim & moderado \\
\hline ambientalistas & ruim & ruim & muito bom & moderado & moderado \\
\hline $\begin{array}{l}\text { usuários para } \\
\text { recreação }\end{array}$ & ruim & ruim & bom & bom & bom \\
\hline $\begin{array}{l}\text { trabalhadores } \\
\text { sem terra }\end{array}$ & moderado & moderado & bom & bom & bom \\
\hline $\begin{array}{l}\text { moradores } \\
\text { locais }\end{array}$ & ruim & ruim & bom & moderado & moderado \\
\hline $\begin{array}{l}\text { gerações } \\
\text { futuras }\end{array}$ & ruim & moderado & muito bom & moderado & bom \\
\hline
\end{tabular}

Então, do ponto de vista econômico, ambiental e de equidade, apenas as opções de alagamento e o misto entre alagamento e agricultura otimizada são aceitas. Mas, apesar do 
alagamento ser a opção que mais apresenta pontos favoráveis ambientalmente, "o misto entre a agricultura otimizada e o alagamento é o único projeto que minimiza os conflitos entre os fazendeiros" (MUNDA, NIJKAMP e RIETVELD, 1994, p.18). "Nenhuma solução ótima foi encontrada, mas algumas ações consideradas defensáveis foram identificadas".

Outros métodos, apoiados ou não por modelos matemáticos, que representam as interrelações das questões mais importantes nas decisões de gerenciamento ambiental (estratégias para redução da poluição do ar, resíduos industriais) e que contemplam diferentes pontos de vista e preferências do decisor são reunidas e apresentadas em Paruccini (1994).

Jumez et al promovem uma abordagem metodológica para a incorporação dos múltiplos critérios de sustentabilidade para facilitar a tomada de decisões dos promotores de habitação social na França. O ponto forte dessa metodologia é a participação dos moradores na tomada de decisões para a execução das mudanças. Os critérios de avaliação de sustentabilidade são colocados à prova dos moradores para a escolha dos aspectos mais importantes e então os problemas são analisados, considerando os fatores técnicos e os humanos (JUMEZ et al, 2002).

Para reduzir o grau de subjetividade na ponderação (ou atribuição de pesos) dos sistemas de avaliação de edificações Silva et al (2003) tratam da utilização do $\mathbf{A H P}^{35}$. Essa ferramenta é utilizada para permitir ao usuário alcançar um conjunto de medidas para alternativas de decisão agregando pesos relativos dos elementos de decisão.

No AHP, a decisão é vista como uma hierarquia de elementos de decisão interrelacionados. Ordenando a hierarquia de decisão, o número de níveis depende da complexidade do problema e do grau de detalhe que o analista requer para solucionar o problema. Os últimos níveis da hierarquia contêm as alternativas de decisão e no topo o objetivo da decisão. Os níveis mais baixos da hierarquia contêm atributos que contribuem para a qualidade da decisão e os detalhes desses atributos crescem à medida que diminui a hierarquia.

Os dados necessários são os ambientais (uso do solo), econômicos (produção, edificações, transporte e infra-estrutura de utilidade, finanças) e sociais (acesso/ acessibilidade, 
segurança, saúde e bem estar da comunidade e capacidade humana) relevantes para o planejamento e projeto em análise (LOMBARDI, 2000).

Mas, uma questão metodológica pode ser debatida em torno dessa ferramenta na análise de sustentabilidade. Como já introduzido anteriormente, a noção de hierarquia contraria as características de pluralidade e indissociabilidade da sustentabilidade, sendo difícil conciliar os dois discursos. Uma vez que a busca da sustentabilidade representa a busca de soluções para os conflitos, considerando a inter-relação entre as diversas questões, estima-se que a hierarquização esteja mais bem relacionada em etapas posteriores a uma análise de sustentabilidade, possivelmente na definição de estratégias ou de ações.

A introdução de indicadores nas avaliações de sustentabilidade agregou a simplificação na percepção do conceito. Para a ONU (2001) a elaboração de indicadores “pode ajudar a compreender as várias dimensões do desenvolvimento sustentável e as complexas interações que ocorrem entre as dimensões". Os indicadores são necessários, segundo a Agenda 21, "porque fenômenos ecológicos, sociais, culturais e econômicos devem ser considerados na tomada de decisões em todos os níveis" e também "porque não há medidas absolutas, que possam ser aplicadas".

A dificuldade de obtenção de dados, a necessidade de prever resultados antecipadamente, a escala, a complexidade da análise dos casos e a importância dos impactos indiretos são também razões relatadas para o desenvolvimento de indicadores.

Os propósitos dos indicadores para a construção civil são definidos por Häkkinen et al (2002):

- definir os critérios de sustentabilidade precisamente;

- medir o desempenho da indústria da construção e do ambiente construído;

- permitir aos tomadores de decisão avaliar estratégias economicamente viáveis e tecnicamente exequíveis para melhorar a qualidade de vida;

- permitir aos atores no processo de construção e desenvolvimento o uso de ferramentas e guias baseados em indicadores para melhorar as práticas e a qualidade da construção.

Os principais usuários dos indicadores de sustentabilidade da construção civil são os órgãos públicos (habitação, edificações, tráfego, ambiente), proprietários, administradores, usuários de edificações, empreiteiras, planejadores, construtores, projetistas e produtores de materiais (HÄKKINEN, 2001). 
A coleta de dados para a composição de indicadores pode ser feita através de questionários com usuários. O processo é enriquecido pela possibilidade de acesso às opiniões e experiências, a descrição do grau de consenso da população, além de propiciar informações sobre problemas não esperados e reduzir os problemas de interpretação dos indicadores propostos (GLAUMANN et al., 2002).

O balanced scorecard proposto por Kaplan e Norton (1997) também pode ajudar a evidenciar as várias dimensões da sustentabilidade, já que na sua origem se propõe a incorporar um conjunto de medidas mais genérico e integrado que vincula o desempenho sob a ótica dos clientes, processos internos, funcionários e sistemas ao sucesso financeiro em longo prazo (ROSSETO et al, 2004b).

Voltado para analisar e visualizar o bom desempenho de uma organização, apresenta os objetivos de curto e longo prazo, os resultados desejados e os vetores de desempenho destes resultados. É identificado como sendo útil na articulação da estratégia a ser adotada, para comunicar essa estratégia e para ajudar a alinhavar iniciativas individuais, organizacionais e interdepartamentais, com a finalidade de alcançar uma meta comum.

Por oferecer uma imagem estática do problema, ainda que para cada situação possa ser desenvolvido um card, a ferramenta é útil somente para mostrar a gama de questões e os passos para a tomada de decisões.

\subsection{Status da pluridimensionalidade dos métodos de avaliação de sustentabilidade}

Para compreender e avaliar o grau de impacto que o setor da construção civil provoca, várias iniciativas nacionais e internacionais, de países desenvolvidos e em desenvolvimento, têm sido elaboradas.

A contribuição tem sido dada principalmente na forma de métodos e sistemas de avaliação de sustentabilidade: na análise de desempenho de produtos e edificações, elaboração de requisitos, análises de ciclo de vida, desenvolvimento de indicadores de sustentabilidade, caracterização de impactos de materiais de construção e edificações.

Este item tem por objetivo investigar a contribuição desses métodos para a visão pluridimensional do conceito e que comportam a avaliação da sustentabilidade das etapas citadas da cadeia produtiva da habitação em madeira de plantios florestais. 
Os métodos de avaliação de sustentabilidade são geralmente classificados quanto ao modo como consideram o ciclo de vida, as questões trabalhadas e áreas de aplicação. A classificação de Trusty (s.d.) é feita de acordo com a abrangência de cada um:

- nível 1: ferramentas de comparação de produtos e fonte de informações. Usadas na etapa de busca, incluindo dados ambientais ou econômicos. Trabalhos baseados em LCA ou para compor LCA;

- nível 2: ferramentas de apoio à decisão ou a projetos de edificações. A abordagem é normalmente focalizada (ambiental, econômica ou energética). São objetivos e usados nas etapas iniciais do projeto, podendo ser baseados em pontuação ou ponderação. São inputs para ferramentas do nível 3;

- nível 3: estruturas ou sistemas de avaliação de toda a edificação. Têm ampla cobertura, ambiental, econômica ou social. Misturam dados objetivos e subjetivos e são baseados em sistemas de pontuação ou ponderação. Podem ser aplicados tanto para novas edificações quanto para as que estão em uso.

A classificação de Häkkinen (2001) é estruturada em métodos baseados em indicadores (A) e métodos sem indicadores (B). Os métodos do tipo A:

- contém conjuntos de indicadores e possivelmente separa indicadores para diferentes tipos de edificação;

- indicadores podem estar relacionados ao tipo de solução técnica, desempenho técnico e funcional da edificação, localização da edificação entre outros;

- o sistema ajuda a analisar o desempenho ambiental da edificação com o auxílio de indicadores.

Os métodos do tipo B caracterizam-se por:

- Abordagens baseadas na análise do ciclo de vida;

- a adequação ambiental é indicada pela liberação de emissões e consumo de recursos naturais;

- a análise é feita por uma ferramenta computacional;

- a ferramenta inclui um perfil ecológico de materiais e energia como bases de dados; 
- as ferramentas calculam o perfil ambiental de toda a edificação baseado nas escolhas dos usuários quanto a estruturas, espaços e sistemas de aquecimento, ventilação, condicionamento de ar e refrigeração.

A classificação de Deakin et al apud Huovila et al (2001) é feita de acordo com a diversidade de dimensões abordadas, sendo portanto mais adequada para o desenvolvimento deste trabalho:

- ambiental - focaliza a avaliação da integridade do ecossistema;

- avaliação ao longo do ciclo de vida - avalia também a equidade, participação e aspecto futuro das questões econômicas, sociais e institucionais, de acordo com a definição PICABUE da sustentabilidade (Figura 24).

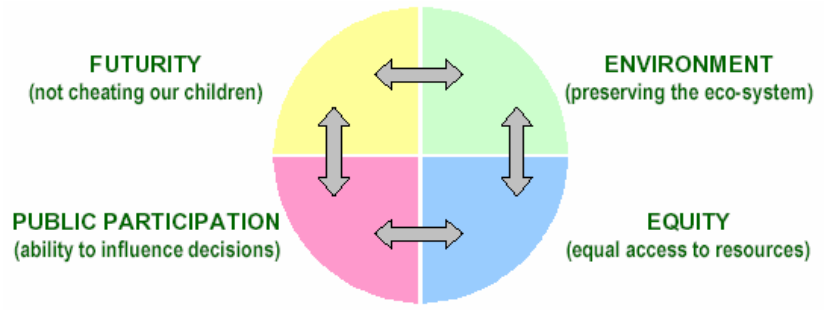

Figura 24. Definição PICABUE de desenvolvimento sustentável fonte: Huovila et al (2001)

Para uniformizar a denominação, é preferível adotar a nomenclatura "unidimensional" e "pluridimensional".

3.3.1. Método de avaliação unidimensional da sustentabilidade da construção civil: dimensão ambiental

\subsubsection{Método das preferências ambientais, Holanda}

O método de preferências ambientais foi elaborado por Anink et al. (1996) motivado pelo contexto da época, quando então ainda se debatiam mais enfaticamente os impactos ambientais conseqüentes das escolhas dos materiais e processos construtivos. DOGGART comenta no prefácio desse livro como o "projeto ambiental" evoluiu, quando no início da década na Europa as perguntas eram “qual material?”, "Quanto custa?" e "Qual a confiabilidade?" e por volta de 1995, a pergunta passou a ser "qual a conseqüência ambiental?". 
O livro apresenta uma análise de ciclo de vida simplificada de materiais freqüentemente utilizados na construção de edificações na Holanda, para auxiliar o projetista na escolha das melhores soluções. Concebido para ser prático e ser utilizado pelos projetistas, para cada função apresenta quatro opções de materiais construtivos, do melhor ao pior quanto ao desempenho ambiental, no contexto holandês.

O método é definido pelo levantamento dos impactos ambientais do ciclo de vida de cada material estudado, que são agrupados por: recursos, energia, emissões aéreas e líquidas, danos ao ecossistema e resíduos sólidos. São analisados também o potencial de reutilização, a facilidade de manutenção e a durabilidade dos materiais. Os materiais são comparados através da construção de uma matriz composta por todos esses elementos, que é a base para a determinação das preferências ambientais.

Também nesse método prevalece o caráter relativo, pela comparação entre quatro alternativas existentes no mercado. Sperb (1999) analisa que a ponderação desse método não é explícita, variando de acordo com o grupo analisado e sua função. Por exemplo, o grupo emissões aéreas prevalece sobre os outros grupos na análise de alternativas de tintas, assim como o grupo recursos é o item mais explorado na avaliação de alternativas de estruturas prediais.

\subsubsection{2. $\mathrm{EBN}^{36}, \mathrm{EUA}$}

Simplificações foram geradas a partir da dificuldade de quantificar e de ponderar os impactos ambientais. Wilson propõe que essa dificuldade seja superada com a utilização de um sistema de avaliação com critérios qualitativos atualizados por uma revisão periódica, elaborada pelo EBN (WILSON, 1997). Esse sistema vem sendo aprimorado desde 1995, quando antes de se configurar como um método, eram propostas apenas diretrizes que visavam a minimização de impactos ambientais nas edificações. O EBN produziu uma lista denominada GreenSpec, de produtos ambientalmente corretos, a partir desses critérios (EBN, 2004; WILSON, 2000). O método, por ser qualitativo, é baseado na obtenção de respostas do tipo ausência ou presença, o que não possibilita flexibilidade ou aprofundamento da análise. 


\subsubsection{Declarações ambientais}

As declarações ambientais têm a intenção de prover informação (baseada no LCA) para os fabricantes e consumidores de produtos de construção capacitando-os para tomar decisões que vão minimizar os impactos ambientais negativos do trabalho de construção e edificação. A declaração ambiental elaborada pelo Trätek ${ }^{37}$ para quinze serrarias de duas variedades de pinheiros (anexo) mostra dados dos produtos, suas embalagens, o tipo de transporte utilizado, processamento (emissões na água, solo e ar, poluição sonora e consumo de energia), uso e reciclagem (reuso, reaproveitamento e disposição final).

Strand e Fossdal (2003) deixam claro que as declarações são apenas uma parte da avaliação ambiental e é apenas um dos elementos do conceito de sustentabilidade.

\subsubsection{ECOPROFILE, Noruega}

Esse método, cuja última versão é de 1999, é de classificação ambiental voluntária com parâmetros de avaliação para o ambiente externo, clima interno e recursos, considerando a totalidade da edificação. Os materiais são analisados somente quanto ao consumo de recursos. Os parâmetros descrevem a edificação em si, a sua manutenção, operação e uso. Boonstra e Pettersen (2003) identificam a necessidade de mudanças para que o método seja mais bem sucedido, reduzindo a quantidade de parâmetros, a melhoria do processo de ponderação e a produção de índices mais concisos.

\subsubsection{Miljöstatus ou Environmental Status, Suécia}

O objetivo desse método é a inspeção e avaliação de edificações (versão 4 - 2002). São cerca de 90 aspectos ambientais, divididos em 4 grupos: ambiente interno, ambiente externo, energia e recursos naturais. A inspeção é basicamente visual, sendo atribuídas notas para cada aspecto. Isso simplifica e reduz custos de avaliação, mas prejudica a confiabilidade (BOONSTRA e PETTERSEN, 2003).

${ }^{37}$ Trätek - Swedish Institute for Wood Technology Research 


\subsubsection{Pegada ecológica}

Desenvolvido por Wackernagel e Rees (1997) propõe explicitar o impacto ambiental convertendo o consumo em um dado ano em área por pessoa. Para tanto são usados dados estatísticos que são convertidos em quantidades de terra "biologicamente" produtiva e água necessárias para produzir os recursos consumidos e para assimilar os resíduos gerados usando as tecnologias mais comuns. Para tanto, segue a média mundial de produtividade o que é uma vantagem, pois possibilita a comparação entre os diferentes países e explicita as diferenças.

Com os dados, faz-se um cruzamento entre a categoria de consumo (alimentação, habitação, transporte, bens e serviços) com os impactos sobre os combustíveis fósseis (cujo valor é expresso em quantidade de floresta necessária para absorver o gás carbônico liberado pelo consumo de combustíveis fósseis - carvão, petróleo e gás natural), áreas agriculturáveis, áreas de pastagem, florestas, área construída (espaço que deixou de ser disponível como ambiente natural porque foi pavimentado ou usado para edificações) e áreas para pesca.

O resultado é apresentado em acres ${ }^{38}$ per capita, considerando a população do local estudado. Por exemplo, a pegada ecológica dos EUA é de 24 acres/ habitante (em 1999), de acordo com os dados da Tabela 10. A partir desse dado é que se torna possível dizer que 'se todos os humanos quisessem alcançar o padrão de vida norte americano seriam necessários quatro planetas Terra para prover todos os materiais e energia demandados.

Tabela 10. Cálculo da pegada ecológica dos EUA

\begin{tabular}{l|c|c|c|c|c|c|c}
\hline $\begin{array}{c}\text { categoria de } \\
\text { consumo }\end{array}$ & $\begin{array}{c}\text { área relativa aos } \\
\text { combustíveis fósseis }\end{array}$ & $\begin{array}{c}\text { área } \\
\text { agriculturável }\end{array}$ & $\begin{array}{c}\text { área de } \\
\text { pastagem }\end{array}$ & florestas & $\begin{array}{c}\text { área } \\
\text { construída }\end{array}$ & $\begin{array}{c}\text { área para } \\
\text { pesca }\end{array}$ & total \\
\hline alimento & 1.7 & 2.2 & 0.8 & 0.0 & 0.0 & 0.7 & 5.4 \\
\hline habitação & 3.5 & 0.0 & 0.0 & 1.4 & 0.3 & 0.0 & 5.2 \\
\hline transporte & 3.9 & 0.0 & 0.0 & 0.0 & 0.5 & 0.0 & 4.3 \\
\hline bens & 4.0 & 0.4 & 0.1 & 1.2 & 0.1 & 0.0 & 5.8 \\
\hline serviços & 1.9 & 0.0 & 0.0 & 0.8 & 0.1 & 0.0 & 2.8 \\
\hline total & 15.0 & 2.6 & 0.8 & 3.4 & 1.0 & 0.7 & $\mathbf{2 3 . 5}$ \\
\hline $\begin{array}{l}\text { Todos os números são expressos em acres per capita (1999) } \\
\text { fonte: traduzido de Redefining Progress (2004) }\end{array}$
\end{tabular}


O método também considera os impactos ambientais onde quer que ocorram, considerando a importação/ exportação de matéria prima e o carreamento de agentes poluidores. A vantagem desse método é a possibilidade de medir a pegada ecológica tanto de uma pessoa, uma comunidade ou mesmo de um país utilizando o mesmo procedimento e efetuar comparações com unidades de medidas facilmente reconhecíveis pelos usuários.

\subsubsection{Ecoquantum, Holanda}

Desenvolvido para o contexto holandês, onde é notório o incentivo por parte do governo para as práticas ambientalmente mais corretas. Para ser utilizado na fase de projeto, cujo público alvo é composto principalmente de arquitetos, era inicialmente orientada para a especificação de materiais (HUOVILA et al, 2001), como no trabalho de Anink et al.

O objetivo dessa ferramenta é determinar, analisar e melhorar o desempenho ambiental de edificações. Calcula os efeitos ambientais de todo o seu ciclo de vida, considerando os fluxos de energia, materiais e água. São analisadas as fases de extração de matéria-prima, produção, construção, uso e demolição ou reuso. Os efeitos ambientais considerados são: esgotamento de matérias primas, combustíveis e camada de ozônio, efeito estufa, esgotamento, chuva ácida, eutrofização, toxicidade para humanos, ecotoxicidade, formação de oxidantes fotoquímicos, energia, resíduos radioativos e inertes. (MAK et al, SUNIKKA et al apud HUOVILA et al, 2001).

\subsubsection{Lista BME, Holanda}

Arruda e Ino (2000) analisam o método criado pelo NIBE $^{39}$ para avaliar o grau de sustentabilidade ambiental de edificações e auxiliar o processo de escolha de materiais ambientalmente mais sustentáveis no contexto holandês. A avaliação é dividida nos tópicos: localização; projeto, insolação e ventilação; materiais; aquecimento; gerenciamento da água; acústica. Baseia-se no preenchimento de dados em planilha, cujos resultados são utilizados na concessão de financiamentos (empréstimo verde) e certificação (selo VIBE). A subjetividade é um dos obstáculos a serem superados em alguns itens para a melhoria da

\footnotetext{
${ }^{38}$ acre - um acre $=4047 \mathrm{~m}^{2}$

${ }^{39}$ NIBE - Instituto Flamengo de Construções e Moradias Bio-Ecológicas
} 
Lista BME. Para a questão dos materiais, o desafio é elaborar um procedimento de análise que equilibre critérios quantitativos e qualitativos.

3.3.2. Método de avaliação unidimensional da sustentabilidade da construção civil: dimensão social

\subsubsection{1. $\quad$ SIA $^{40}$}

A questão principal a ser respondida por esse método é "quem ganha e quem perde?”, avaliando o impacto das políticas, planos ou projetos sobre as pessoas. O objetivo é prever e avaliar os impactos antes que aconteçam. Apesar de ser voltado para utilização em escala urbana ou maior, as características do método estão sendo apresentadas por serem específicas da dimensão social. É uma abordagem multi-método, que utiliza metodologias e técnicas de pesquisa social, indicadores sociais (objetivos e subjetivos) e é voltado para a fase de projeto (MAMBELLI, 2000).

Os princípios da SIA segundo o INTERORGANIZATIONAL COMMITTEE ON GUIDELINES AND PRINCIPLES FOR SOCIAL IMPACT ASSESSMENT (1994) são:

- identificar e envolver todos os grupos e indivíduos potencialmente afetados;

- identificar claramente quem ganha e quem perde e enfatizar a vulnerabilidade dos grupos mal representados;

- lidar com as questões e preocupações públicas que realmente interessam, não apenas as que são fáceis de lidar;

- descrever como a avaliação de impacto social é conduzida, quais são os pressupostos e como a sua significância é determinada;

- identificar problemas que poderiam ser solucionados com mudanças para a ação proposta ou alternativas;

- cientistas sociais treinados empregando métodos de ciências sociais podem dar melhores resultados;

- gerenciar a incerteza através do monitoramento e mitigação de impactos adversos;

- utilizar literatura científica e dados primários e secundários sobre a área afetada;

- avaliar a lacuna de informação e desenvolver uma estratégia de encaminhamento. 
3.3.3. Método de avaliação bidimensional da sustentabilidade da construção civil: dimensões ambiental e econômica

\subsubsection{Ecoeffect, Suécia}

O método faz uma abordagem das questões ambientais de edificações novas, estudando 5 áreas de avaliação independentemente ou em paralelo: uso de energia, uso de materiais, ambiente interno, ambiente externo (entorno imediato da edificação) e custo do ciclo de vida. A estrutura é baseada na quantificação do impacto ambiental na forma de indicadores e apresentação dos resultados em um perfil ambiental, num gráfico de barras, mostrando a contribuição dos vários efeitos ambientais (ECOEFFECT, 2004). A questão dos materiais é trabalhada no EcoEffect quanto ao consumo de recursos naturais, emissões, resíduos e consumo de energia.

\subsubsection{BEES, EUA}

O software BEES ${ }^{41}$, elaborado pelo NIST ${ }^{42}$, é baseado na análise do ciclo de vida. Criado em 1994 trata-se de uma ferramenta de apoio à tomada de decisões na fase de projeto para escolha de materiais e componentes ambiental e economicamente mais adequados, que são avaliados ao longo de todo o seu ciclo de vida, segundo as normas da ISO 14000. O público alvo são os projetistas, construtores e fabricantes de produtos.

O método propõe um levantamento exaustivo de dados quantitativos para apurar a fundo todas as liberações ao ar, solo e água que podem contribuir para os impactos ambientais dos materiais mais utilizados no contexto americano, possibilitando uma completa compreensão da gama de impactos possíveis. O software avalia as etapas de aquisição de matérias-primas, manufatura, transporte, instalação, utilização, reciclagem e gerenciamento de resíduos de materiais de construção e por isso considera não somente o item analisado, mas todo o conjunto de materiais necessários para compor o produto final, como pregos, parafusos, tintas.

Os aspectos analisados são os resíduos sólidos, emissões no ar, solo e água e sua relação com os seguintes impactos ambientais: aquecimento global, chuva ácida, eutrofização do solo e água, exploração de recursos naturais, geração de resíduos sólidos e qualidade do ar

${ }^{41}$ BEES 3.0 - Building for Environmental and Economic Sustainability

42 NIST - National Institute of Standards and Technology, EUA 
interno de edificações. Além disso, é analisado também o consumo de energia ao longo do ciclo de vida de cada produto. Para o cálculo do desempenho ambiental, os dados de impactos provocados por cada material são então uniformizados quanto à unidade de medida, através de normas da ASTM (LIPPIATT, 2002).

Para determinar o grau de importância relativa dos impactos analisados são considerados sistemas de ponderação, além da possibilidade de interferência pelo próprio usuário, considerando as especificidades regionais e locais.

Os resultados obtidos na análise de desempenho ambiental são sempre relativos, baseados na comparação com os outros produtos apresentados, sendo, portanto importante verificar quais são as alternativas em análise.

O desempenho econômico é medido pelos custos de investimento inicial, reposição, operação, manutenção e conserto e disposição final e então pode ser combinada com o desempenho ambiental. Essas operações são realizadas de acordo com as normas americanas ASTM (método de custo do ciclo de vida e análise de decisão multi atributo).

A versão 1.0 em 1998 abrangia 20 produtos, agrupados de acordo com a sua função na edificação (concreto com adições, isolamentos térmicos, revestimentos internos de parede e teto, revestimentos externos, coberturas e pisos) e atualmente a versão 3.0 engloba cerca de 200 produtos, classificados de acordo com o padrão ASTM (UNIFORMAT II). Novos materiais também podem ser incorporados na análise, mas requer um trabalho anterior de coleta de dados de entradas (energia, água e matérias-primas) e saídas (emissões aéreas, efluentes líquidos, resíduos sólidos entre outros) de todo o ciclo de vida do novo produto.

3.3.4. Método de avaliação bidimensional da sustentabilidade da construção civil: dimensões ambiental e social

\subsubsection{Green Globes, Canadá}

Com origem em 2002, foi desenvolvido a partir do BREEAM- Green Leaf para avaliação de edificações como um todo, a ser utilizado pelos usuários (GREEN GLOBES, 2004, BOONSTRA e PETTERSEN, 2003). A estrutura conta com o preenchimento de questionários on line confidenciais para cada estágio do projeto, a partir dos quais são gerados uma avaliação global e relatórios-guia. São analisados dois estágios: a concepção do projeto e no planejamento da obra. As notas são dadas para a edificação (em pontos) e por 
comparações com outras edificações, podendo virar um benchmark (SKOPEK, MARSHALL e BRYAN, 2002).

Os itens de avaliação são analisados separadamente em: gerenciamento ambiental da edificação, energia e transporte, água, recursos (gerenciamento de resíduos e manejo do solo), redução da poluição (emissões, efluentes, materiais perigosos, sistema de informação de materiais perigosos para os trabalhadores etc) e ambiente interno (iluminação, conforto, barulho etc), prevalecendo o enfoque ambiental, minimamente considerando a visão integrada.

O propósito final desse método é além da avaliação da edificação, a criação de consciência e capacitação do usuário para buscar soluções mais adequadas para reduzir os seus impactos ambientais.

\subsubsection{2. $\mathrm{GBD}^{43}$, Reino Unido}

O GBD, assim como o EBN, trabalha com a publicação de informativos impressos periódicos, apresentando dados de análises de materiais produzidos comercialmente, embasado por várias referências bibliográficas. Os tópicos abordados pelo GBD são: energia, materiais isolantes, alvenaria, madeira, chapas de compósitos, produtos preservativos de madeira, esquadrias, tintas e stains, materiais de cobertura, utilidade da água de chuva, sanitário e disposição de esgoto sanitário, carpetes e revestimentos de piso, membranas de cobertura planas, vidros, instalações elétricas, adesivos, construções com palha (GREEN BUILDING DIGEST, 1995).

O objetivo do GBD é a produção e disponibilização de informação sobre as questões ambientais para projetistas e compradores de materiais de construção que queiram incluir considerações ambientais na tomada de decisões. A base é um levantamento de impactos ambientais relevantes ao longo do ciclo de vida dos materiais, separados entre produção (extração, processamento, produção e distribuição) e utilização (instalação, uso e disposição final), de forma qualitativa. É esperado que, dessa forma, não só o impacto seja minimizado, mas também haja um estímulo aos bons produtos e práticas por parte dos fabricantes.

${ }^{43}$ GBD - Green Building Digest 
As questões ambientais, globais ou locais, analisadas na produção são os gastos energéticos, exploração de recursos naturais, aquecimento global, chuva ácida, redução da camada de ozônio, emissão de substâncias tóxicas, geração de fumaça fotoquímica e saúde dos operários. Na utilização, os impactos analisados são a durabilidade e manutenção, riscos à saúde dos ocupantes da edificação, potencial de reciclagem, potencial de reutilização e tipo de disposição final de cada material.

Mesmo com um processo de análise qualitativa, os resultados das análises são apresentados em uma escala de cinco níveis, de "nenhuma evidência de impacto ambiental" a "máximo impacto ambiental". Os critérios desse procedimento são relativos, comparando os materiais apresentados dentro de cada informativo (SPERB, 1999).

\subsubsection{3. $\quad \mathrm{CASBEE}^{44}$, Japão}

Elaborado em 2002, trata-se de uma avaliação ambiental para todas as fases do desenvolvimento de projeto (pré-projeto a pós-projeto) de edificações, compreendendo um conjunto de ferramentas. Utiliza categorias Q (qualidade e desempenho ambiental da edificação - "representa a condição do ambiente avaliado em termos de facilidades para os usuários") e L (redução das pressões ambientais da edificação - "o impacto ambiental negativo que emana para o ambiente público além de um determinado limite espacial hipotético" no entorno da edificação). A eficiência ambiental da edificação (BEE) é definida por $\mathrm{BEE}=\mathrm{Q} / \mathrm{L}$ e o resultado é apresentado na forma de uma pontuação geral ou representação em gráfico, que pode ser utilizado para rotulagem. Os aspectos analisados são o consumo de energia, uso cíclico dos recursos, ambiente local e ambiente interno. (MURAKAMI et al, 2002; CASBEE, 2004).

\subsubsection{Pimwag, Finlândia}

Criada para avaliar projetos habitacionais experimentais, são critérios ecológicos para avaliação de desempenho em cinco aspectos: poluição, recursos naturais, salutabilidade, biodiversidade da natureza e nutrição (AALTONEN et al apud HUOVILA et al, 2001). Os dados são apresentados em forma de tabela de pontos. As dimensões trabalhadas são a ambiental e a social (em relação à questões de saúde). 


\subsubsection{Twin model, Holanda}

Num contexto em os métodos baseados em LCA não são muito práticos por exigirem a utilização de dados quantitativos, o Twin-model propõe a suplementação com dados qualitativos, possibilitando a comparação. A avaliação é feita sobre o aspecto ambiental e de saúde.

3.3.5. Método de avaliação bidimensional da sustentabilidade da construção civil: dimensões econômica e social

\subsubsection{1. $\quad \mathrm{SCBA}^{45}$}

Apresentado no Bequest Toolkit no conjunto de ferramentas de avaliação de sustentabilidade, o SCBA é definido como a "análise de eficiência desenvolvida para estabelecer uma mudança no bem estar de uma sociedade como um todo".

Esse método também parte de uma análise de "ganhadores" e "perdedores"; identificação dos impactos do projeto; identificação de quais impactos são economicamente relevantes e a valoração monetária dos efeitos relevantes. O objetivo é determinar os efeitos de eficiência e equidade de uma ação proposta, expressando os impactos de uma política ou iniciativa monetariamente para ajudar a fazer um julgamento sobre a exeqüibilidade sócioeconômica de uma ação.

A política é socialmente bem sucedida quando os resultados são maximizados dentro de um determinado orçamento ou quando num resultado os custos sociais são minimizados. A avaliação de equidade lida com a distribuição dos custos, benefícios, renda, possibilidades de crescimento entre grupos de cidadãos ou regiões (YLI-KARJANMAA, 2000).

Várias questões podem ser abordadas sobre os procedimentos adotados, como a valoração de aspectos sociais em termos econômicos, a viabilidade de ponderar as questões mais ou menos relevantes, entre outros. Esses aspectos serão abordados adiante.

\footnotetext{
${ }^{44}$ CASBEE - Comprehensive Assessment System for Building Environmental Efficiency

${ }^{45}$ SCBA - Análise de custo-benefício social
} 
3.3.6. Método de avaliação tridimensional da sustentabilidade da construção civil: dimensões ambiental, econômica e social

\subsubsection{LEED, EUA}

O LEED ${ }^{46}$, elaborado por membros do $\mathrm{USGBC}^{47}$ é um esforço de criação de um padrão para edificações ecológicas (green buildings) para ser utilizado como um guia de projeto e como um sistema de certificação. O objetivo é a melhoria do bem estar dos usuários e aumentar o desempenho ambiental e o retorno econômico da edificação usando práticas, padrões e tecnologias inovadoras (USGBC, 2002).

Avalia edificações comerciais ou residenciais, novas ou já construídas, ambientes internos de edificações comerciais e coberturas. O método usa um esquema de pontuação, facilitado com o uso de um checklist, para a certificação de edificações, conferida com base no total de créditos obtidos, não havendo um número mínimo de créditos por categoria.

Os aspectos analisados são o uso sustentável do solo, eficiência no uso da água, energia, emissões na atmosfera, materiais e recursos, qualidade do ar interno e inovações de projeto. Os materiais são analisados quanto ao armazenamento e coleta de recicláveis, edificações reutilizadas, gerenciamento de resíduos de construção, reaproveitamento de recursos, conteúdo de reciclados, uso de materiais locais/ regionais, velocidade de renovação dos materiais e uso de madeira certificada. São listados os documentos comprobatórios e sugeridas estratégias e quando há, tecnologias potenciais para atender ao requisito (USGBC, 2002).

\subsubsection{ISO}

A ISO está desenvolvendo padrões e indicadores para a construção sustentável, mas adota uma visão do conceito bastante limitada ao enfoque ambiental: "a manutenção dos componentes e funções do ecossistema para as futuras gerações" (ISO apud Strand e Fossdal, 2003). Basicamente, segue as seguintes diretrizes para o desenvolvimento dos princípios:

- Ambiental: o projeto, construção e operação devem implementar a abordagem DfE (projeto para o ambiente). O funcionamento saudável dos ecossistemas locais, regionais

\footnotetext{
${ }^{46}$ LEED - Leadership in Energy and Environmental Design, EUA

${ }^{47}$ USGBC - United States Green Building Council
} 
e globais deve ser promovido e a eficiência energética, toxicidade, materiais, durabilidade, reuso e as operações devem ser incorporadas.

- Social: o projeto, construção e operação devem incorporar a colaboração, impactos sociais e a melhoria contínua.

- Econômica: a construção sustentável deve incorporar procedimentos de coleta de todo o custo no desenvolvimento de edificações e bens construídos. Deve considerar não somente os custos diretos, mas também os custos sociais e ambientais diretos e indiretos.

A dimensão ambiental, acompanhando o contexto das avaliações de sustentabilidade, está mais desenvolvida do que as demais (Figura 25).

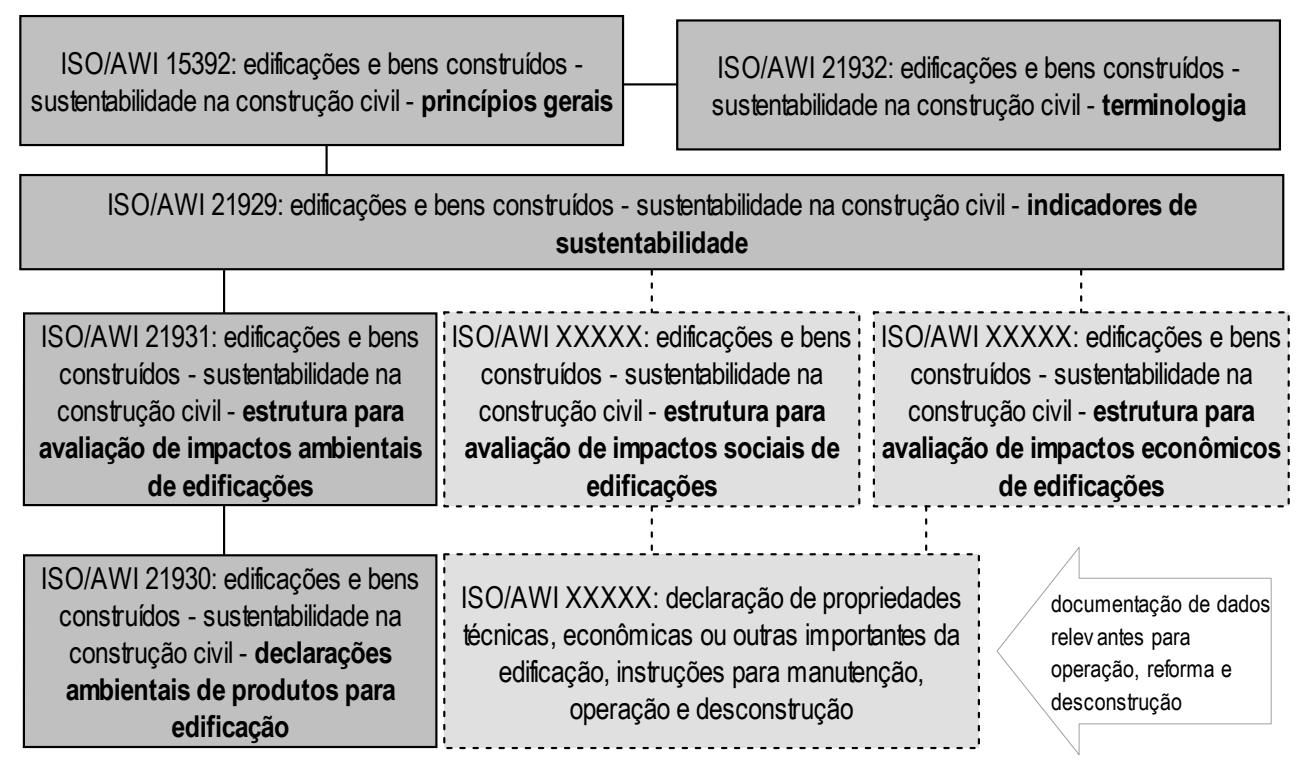

Figura 25. Padrões em desenvolvimento e em planejamento na área da construção sustentável da ISO. fonte: traduzido de ISO apud Strand e Fossdal (2003, p.34)

\subsubsection{EcoProP, Finlândia}

É um software de gerenciamento de requisitos para definir os objetivos de desempenho de uma edificação a ser projetada e construída. É composto por uma classificação geral das propriedades da edificação, referências de requisitos ambientais, dados de métodos de verificação relevantes e procedimentos automatizados para buscar perfis de requisito e para definir o projeto (HUOVILA et al, 2001). 
Considera as necessidades dos proprietários, usuários e da sociedade como um todo. Os requisitos são elaborados quanto a desempenho (condições do ambiente interno, vida útil, adaptabilidade, segurança, conforto, acessibilidade e aptidão para uso) e impactos ambientais e de custo (custo do ciclo de vida, pressão ambiental sobre o uso do solo, pressão ambiental das edificações).

\subsubsection{Ecopoints, Reino Unido}

O UK Ecopoint mostra o impacto ambiental total de um determinado produto ou processo utilizando a "ecopoint" como unidade de medida única. É calculado em relação aos impactos sobre o ambiente no Reino Unido, utilizando dados de LCA. Os ecopoints são utilizados em outras ferramentas, como o ENVEST para a comparação de diferentes impactos ambientais, ou ainda por fabricantes de materiais para comunicação de desempenho ambiental (DICKIE et al apud HUOVILA et al, 2001). O Bequest Toolkit analisa o método de acordo com as dimensões trabalhadas (Figura 26).

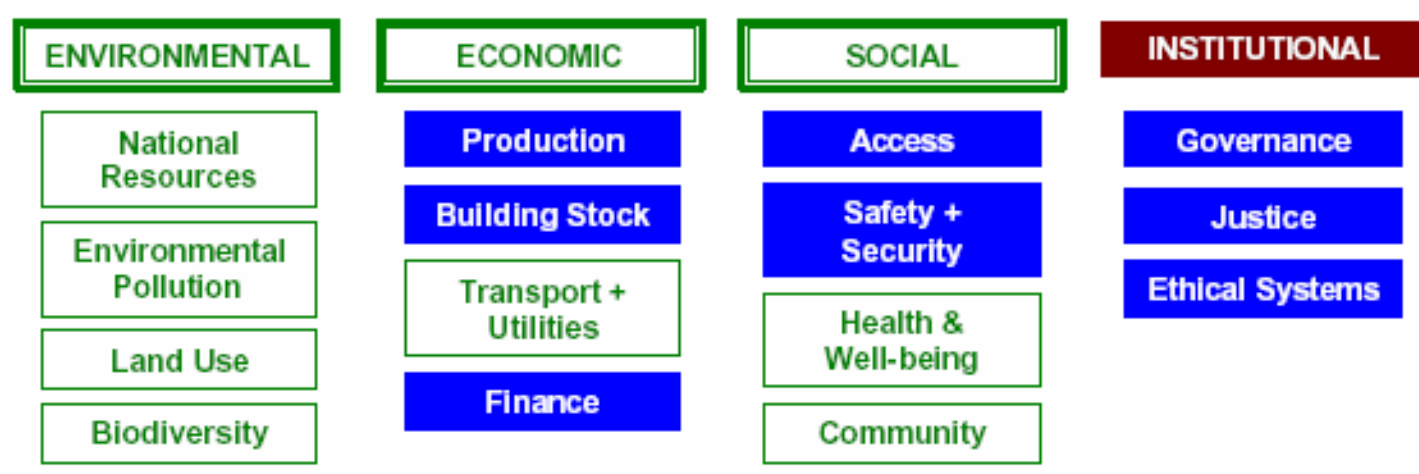

Figura 26. Questões e dimensões trabalhadas pelo Ecopoints - em branco. fonte: HUOVILA et al (2001, p.9)

\subsubsection{NABERS ${ }^{48}$, Austrália}

Elaborado em 2001 para avaliar o desempenho de edificações em uso, não é adequada para novas edificações por ser determinada principalmente pelo comportamento dos usuários.

Desenvolvido para ser trabalhado integradamente com outras ferramentas, utiliza medidas reais, com dados obtidos no edifício e com os usuários. São medidos: consumo de energia,

${ }^{48}$ NABERS - National Australian Building Environmental Rating System 
emissões que contribuem para o efeito estufa, consumo de água, destinação da água de chuva, poluição da água de chuva, esgoto, diversidade da paisagem, transporte, qualidade do ar interno, satisfação dos usuários, resíduos e materiais tóxicos. O público alvo são os investidores, projetistas, construtores, proprietários e usuários (NABERS, 2004).

A abordagem desse método é enfraquecida pela ausência de outras fases do ciclo de vida na análise, comprometendo a visão de sustentabilidade desejada (BOONSTRA e PETTERSEN, 2003).

\subsubsection{CRISP}

O projeto do $\mathrm{CRISP}^{49}$ é uma revisão das abordagens de desenvolvimento de indicadores internacionalmente aceitos - UN (CSD) ${ }^{50}$, EEA (DPSIR typology) $)^{51}$, OECD (PSR model) ${ }^{52} \mathrm{e}$ $\mathrm{WBCSD}^{53}$ - e de indicadores formulados especificamente para o setor da construção civil $\mathrm{GBC}^{54}$, ISO $14000, \mathrm{CIB}^{55}$ e $\mathrm{WHO}^{56}$.

As proposições de indicadores da UN (CSD), OECD, WBCSD apresentam similaridades no sistema básico de indicadores, chamado "DPSIR" (pressão, problema, estado, impacto, resposta) e a EEA apresenta a tipologia que engloba as anteriores.

Os indicadores ambientais da OECD são organizados por questões (mudanças climáticas, redução da camada de ozônio, qualidade do ar, resíduos, qualidade da água, fontes de água, recursos florestais, fontes de peixes e biodiversidade). São também apresentados alguns indicadores socioeconômicos, mas relacionados à dimensão ambiental: GDP e população, consumo, energia, transporte, agricultura e despesas.

O EEA baseia-se numa estrutura ampliada da influência-estado-resposta, que se constitui em influência-pressão-estado-impacto-resposta e cria relações entre esses tipos de indicadores: "influências sociais e econômicas exercem pressão no ambiente e como conseqüência, o estado do ambiente muda, assim como a garantia de condições adequadas de saúde, disponibilidade de recursos e biodiversidade. Isso leva aos impactos na saúde humana, ecossistemas e materiais. Por outro lado, isso pode provocar a resposta da

\footnotetext{
${ }^{49}$ CRISP - Network on Construction and City related Sustainability Indicators

${ }^{50}$ ONU (CSD) - United Nations (Commission on Sustainable Development)

${ }^{51}$ EEA (DPSIR typology) - European Environment Agency (Driving forces, Pressure, State, Impact, Response)

${ }^{2}$ OECD (PSR model) - Organization for Economic Co-operation and Development (pressure-state-response)

${ }^{53}$ WBCSD - World Business Council for Sustainable Development

${ }^{54}$ GBC - Green Building Challenge

${ }_{55} \mathrm{CIB}$ - Conseil International du Batiment

${ }^{56}$ WHO - World Health Organization
} 
sociedade que retroalimenta nas pressões, no estado ou nos impactos diretamente, através de ações de adaptação ou remediação".

Häkkinen (2001) chama a atenção para a relação entre os diferentes elementos: a relação entre a influência e a pressão é a eco-eficiência da tecnologia, quanto maior a ecoeficiência menor será a pressão advinda da influência. Da mesma forma, "a relação entre os impactos nos humanos e ecossistemas e o seu estado depende das suas capacidades de carga e limites. A resposta da sociedade aos impactos depende de como esses impactos são percebidos e avaliados; e os resultados da resposta sobre a influência dependem da eficácia da resposta".

A EEA define 4 tipos de indicadores, de acordo com o Quadro 25.

\begin{tabular}{|c|c|}
\hline pergunta & tipos de indicadores \\
\hline $\begin{array}{l}\text { o que está acontecendo com o } \\
\text { ambiente e com os humanos? }\end{array}$ & $\begin{array}{l}\text { indicadores descritivos baseados na estrutura DPSIR: } \\
\text { - indicadores de pressão: descrevem o desenvolvimento social, } \\
\text { demográfico e econômico nas sociedades e as } \\
\text { correspondentes mudanças nos estilos de vida, níveis de } \\
\text { consumo e padrões de produção; } \\
\text { - indicadores de problemas: descrevem o desenvolvimento da } \\
\text { liberação de emissões, uso dos recursos e da terra; } \\
\text { - indicadores de estado: descreve quantitativamente e } \\
\text { qualitativamente fenômenos físicos, biológicos e químicos; } \\
\text { - indicadores de impacto: descrevem impactos causados pelas } \\
\text { mudanças da condição do ambiente; } \\
\text { indicadores de resposta: descrevem as reações de grupos } \\
\text { sociais assim como as tentativas governamentais para } \\
\text { prevenir, compensar ou se adaptar às mudanças. }\end{array}$ \\
\hline isso é importante? & $\begin{array}{l}\text { indicadores de desempenho: comparam as condições atuais com } \\
\text { um conjunto de condições de referência. Medem a distância entre } \\
\text { a situação atual e a situação alvo. Podem gerar dados sobre as } \\
\text { entidades, seu gerenciamento e suas operações. São os } \\
\text { indicadores mais utilizados pela ISO. }\end{array}$ \\
\hline estamos melhorando? & $\begin{array}{l}\text { indicadores de eficiência relacionam os problemas com as } \\
\text { atividades humanas. Esses indicadores geram idéias sobre a } \\
\text { eficiência de produtos e processos em relação a recursos usados, } \\
\text { emissões e resíduos gerados por unidade de produto. }\end{array}$ \\
\hline no geral, estamos melhor? & $\begin{array}{l}\text { indicadores de bem estar totais: objetivam descrever a } \\
\text { sustentabilidade total. }\end{array}$ \\
\hline
\end{tabular}

Quadro 25. Tipos de indicadores da estrutura EEA. fonte: traduzido e adaptado de Häkkinen (2001) 
O WBCSD sugere o uso de indicadores em dois níveis de importância, sendo o menos importante determinado pela empresa ou setor analisado. Os indicadores de primeira importância identificados são:

- Valor: massa ou número de produtos ou serviços produzidos ou vendidos e venda líquida. Outros indicadores potenciais: valor agregado, margem de operação, lucro/ salário/ retorno.

- Influência ambiental: consumo de energia, consumo de materiais, consumo de água, emissões de gases do efeito estufa, emissões de substâncias que reduzem a camada de ozônio. Outros indicadores potenciais: emissões para acidificação, $\mathrm{DBO}^{57}$ e $\mathrm{DQO}^{58}$ nos efluentes líquidos, emissões de compostos orgânicos voláteis, emissões de poluentes orgânicos persistentes, emissões de metais pesados, uso do solo.

HÄKKINEN reconhece que apesar de boa parte do cálculo da eco-eficiência poder ser feita com métodos da análise do ciclo de vida, ainda há uma parcela de conteúdo que depende de uma análise subjetiva.

O CRISP organiza os indicadores de acordo com o tipo (pressão, desempenho, estado, impacto, resposta ou eficiência), nível de impacto (global, nacional, regional ou local), questão do desenvolvimento sustentável (econômico, social ou ambiental) e categoria de construção (urbano, infra-estrutura, edificações, produtos ou processos).

\subsubsection{GBTool $^{59}$}

Criado pelo GBC, é utilizado atualmente por integrantes de 24 países, desenvolvidos e em desenvolvimento, e analisa edificações já produzidas e em produção, coletando dados de construção, uso e demolição. A ferramenta é uma estrutura genérica baseada em uma série de indicadores (um para cada categoria de análise) aceita internacionalmente, que possa ser usada para comparar com outros métodos existentes e para produzir sistemas regionais (LARSSON, 2003).

O projeto idealizado por Cole e Larsson (1998) desde o início propunha a difusão do método, quando então contavam com a participação de 14 grupos de pesquisa internacionais. As edificações são analisadas sob seis aspectos: consumo de recursos

\footnotetext{
${ }^{57} \mathrm{DBO}$ - demanda biológica de oxigênio

${ }^{58}$ DQO - demanda química de oxigênio

${ }^{59}$ GBTool - Green Building Assessment Tool
} 
(energia, solo, água e materiais), emissão de poluentes (no ar, água e solo), qualidade do ambiente interno (qualidade do ar, conforto térmico, lumínico e acústico), vida útil, custos iniciais e ao longo do ciclo de vida, prioridades durante o projeto e a construção, fatores contextuais (condições atmosféricas, transporte, uso do solo, edificações existentes, abastecimento de água entre outros).

Strand e Fossdal (2003) analisam a necessidade de simplificação e adaptação da estrutura de avaliação desse método para países em desenvolvimento, o que, de acordo com Larsson (2003) vem sendo feito com a atuação dos diversos parceiros, sobre as condições de cada país participante, evidenciando as diferenças entre si, como as fontes de energia, prioridades ambientais, eficiência de custo entre outros.

\subsubsection{BREEAM, Reino Unido}

O BREEAM ${ }^{60}$, lançado em 1990, aborda as questões de gerenciamento global e local, consumo de energia e emissão de gás carbônico, saúde e bem estar no ambiente interno e externo, poluição, transporte, uso do solo, conseqüências ambientais do uso dos materiais de construção, consumo e eficiência no uso da água.

Assim como o LEED, também se baseia na obtenção de um indicador global, com a somatória de créditos em cada aspecto avaliado. Curwell (1999) comenta que esse é um ponto fraco do sistema, pois possibilita que a baixa pontuação de aspectos-chave, como o consumo de energia, sejam mascarados por outros menos importantes.

O sistema pode ser usado para avaliação de ambientes de trabalho, unidades industriais, supermercados e habitações novas e já construídas. Os resultados podem variar entre razoável, bom, muito bom e excelente e podem ser utilizados para propósitos promocionais (BREEAM, 2003).

Para as habitações o BREEAM desenvolveu um sistema específico denominado EcoHomes. O Green Guide to Housing Specification, ligado ao EcoHomes, é similar ao método das preferências ambientais, acrescido de dados de custo e de saúde e bem estar dos usuários Os grupos de análise são: paredes externas, divisórias, piso, acabamento e outros (ANDERSON et al; HOWARD et al apud HUOVILA et al, 2001). 


\subsubsection{MaSe-System, Noruega}

A falta de comunicação entre usuário e ferramenta durante o processo de análise nos métodos de avaliação de materiais é uma das questões identificadas na elaboração desse método. Strand (2002) diz que o usuário "é freqüentemente desprovido de suporte no procedimento de avaliação e não pode ver a razão de um determinado resultado”.

O desenvolvimento desse método partiu das análises de métodos multi-atributos de tomada de decisão (STRAND, 2002) pela similaridade estrutural entre problemas ambientais e problemas que são solucionados em tomada de decisão com múltiplos critérios. As áreas de análise do MaSe System são os recursos, ecologia, saúde e economia.

A vantagem desse método é dar ao usuário a visibilidade de toda a gama de possibilidades de adequação ambiental que os materiais podem apresentar. Mas, da mesma forma que os outros métodos, não há menção sobre a interação entre as questões das múltiplas dimensões.

\subsubsection{0. $\quad$ SBAT $^{61}$, África do Sul}

Esse método é voltado para uso em países em desenvolvimento, para complementar a discussão de sustentabilidade que, nos métodos de países desenvolvidos, está focalizada na dimensão ambiental (HILL, BOWEN e OPPERMAN, 2002). Enfatiza os aspectos econômicos e sociais, além dos ambientais, para analisar não apenas a sustentabilidade do edifício, mas também a extensão de sua contribuição para o apoio e desenvolvimento de sistemas mais sustentáveis em seu torno (GIBBERD, 2004).

As etapas propostas para a utilização do SBAT são o estudo preliminar, a análise do terreno, a definição das metas, o detalhamento do projeto, construção, operação e reuso/ reforma/ reciclagem.

O propósito é fornecer um guia com indicações para o desempenho das edificações em termos de sustentabilidade, através da coleta e interpretação de indicadores de desempenho simples. São 15 áreas de avaliação, sob as 3 dimensões básicas da sustentabilidade:

\footnotetext{
${ }^{60}$ BREEAM - Building Research Establishment Environmental Assessment Method, Reino Unido

${ }^{61}$ SBAT - Sustainable building assessment tool
} 


\begin{tabular}{|l|l|l|}
\hline \multicolumn{1}{|c|}{ ambiental } & \multicolumn{1}{c|}{ econômica } & \multicolumn{1}{c|}{ social } \\
\hline \hline Água & Economia local & Conforto do usuário \\
\hline Energia & Eficiência do uso & Ambientes inclusivos \\
\hline Resíduos & Adaptabilidade e flexibilidade & Acesso às vantagens (facilities) \\
\hline Local & Custos em andamento & Participação e controle \\
\hline Materiais e componentes & Custos financeiros & Educação, saúde e segurança \\
\hline
\end{tabular}

Quadro 26. Áreas de avaliação do SBAT. fonte: traduzido de Gibberd (2004)

Para cada área, são definidos 5 critérios de avaliação (totalizando 75 indicadores), para definir o tamanho e tipo de impacto que uma edificação provoca. No exemplo da economia local, Gibberd mostra que a análise identifica a influência:

- das empresas e mão-de-obra locais na construção da edificação;

- dos materiais locais na edificação;

- dos componentes, acabamentos e mobiliário locais na edificação;

- dos pequenos empreendimentos (empreiteiras, fabricantes ou comerciantes). Se estes são apoiados durante o processo de construção (por exemplo, através do treinamento em construção e administração de empreendimentos) ou na edificação finalizada (por exemplo, através do acesso ao espaço e vantagens a custo baixo ou gratuitamente);

- da manutenção da edificação e de seus sistemas localmente.

O método agrega mais questões, mas o procedimento é similar, como pode ser observado na apresentação do resultado, num gráfico do tipo radar. 


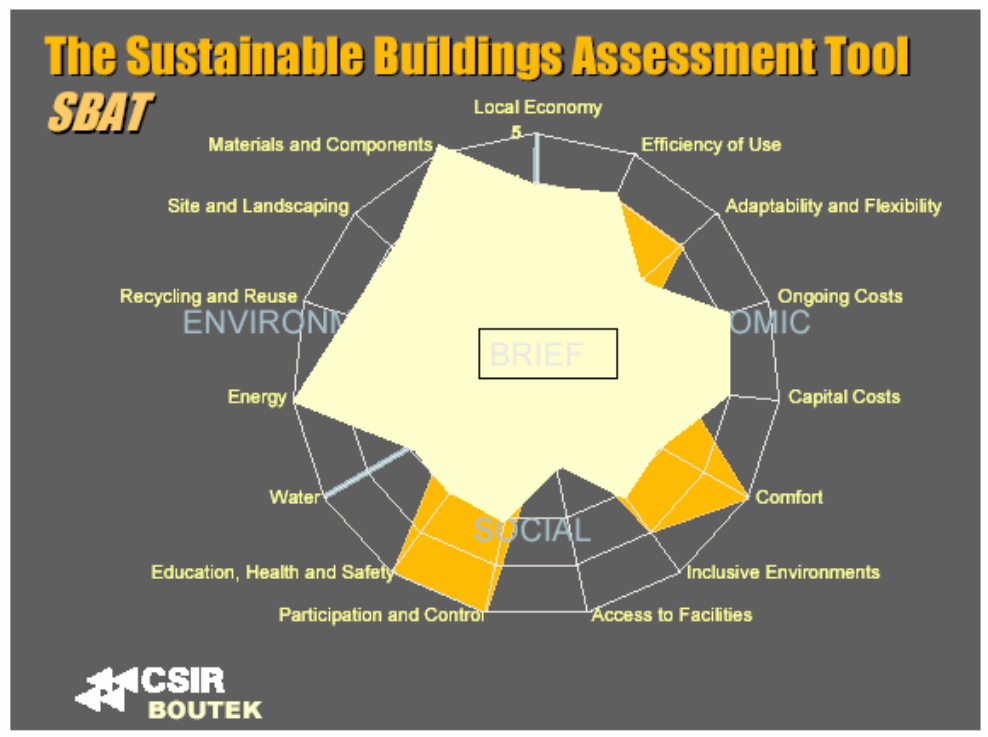

Figura 27. Exemplo de relatório SBAT. fonte: Gibberd (2004)

Kaatz et al (2002) observam que o SBAT compromete a abrangência das questões de sustentabilidade pela excessiva busca pela simplicidade, mas considera aspectos importantes para países em desenvolvimento, como a participação, valores culturais e condições regionais específicas. Isso acaba gerando outra questão: a dificuldade de comparar o desempenho de edificações similares, já que os benchmarks e as metas de sustentabilidade são diferentes para cada edificação.

\subsubsection{Athena, Canadá}

Projetado para ser utilizado por arquitetos, construtores, planejadores e consumidores. A ferramenta compara materiais de construção baseado na sua "superioridade" em seis etapas da sua vida útil. Foi utilizado para comparar madeira, metal e concreto desde a extração, processamento, construção, uso demolição e deposição/ reuso/ reciclagem.

Os resultados mostram que a madeira é ambientalmente mais correto que o metal ou o concreto em termos de consumo de energia, produção de gases do efeito estufa, poluição do ar e água, produção de resíduos sólidos e consumo de recursos em geral. "Em todas as categorias, o Athena mostra que a madeira tem o impacto ambiental mais baixo em cada uma das seis categorias. Por ser renovável, com altas propriedades de isolamento, alta reciclabilidade e taxas de recuperação de recursos e baixas taxas de poluição na colheita e 
serramento, a madeira é considerada um material ambientalmente amigável" (ATHENA, 2004).

\subsection{Comentários}

Vários outros métodos são disponíveis, com estruturas e termos diferentes, mas com o núcleo de questões de sustentabilidade similares aos apresentados neste item. Outros métodos também não foram apresentados porque se destinam à análise de edifícios de apartamentos (HK-BEAM ${ }^{62}$ v.3/99, 2004), edificações de uso comercial ou outro fim (HKBEAM v.1/96R e v.2/96R, HQE ${ }^{63}$, ENVEST) ou ainda destinados para a avaliação do ambiente urbano (BEQUEST ${ }^{64}$ (2004); Avaliação financeira de comunidades sustentáveis, $\mathrm{CIE}^{65}$ ), fora do escopo do estudo. Além desse motivo, os métodos excluídos têm praticamente o mesmo núcleo de questões de sustentabilidade.

Com a profusão de novos métodos, têm sido cada vez mais recorrentes os trabalhos que analisam conjuntos de métodos, efetuando comparações, arrolando vantagens e desvantagens em relação a determinados usos e a viabilidade de fusão ou integração para atender aos diferentes tipos de edificação e usuários (BOONSTRA e PETTERSEN, 2003; ASSEFA, 2002, SKOPEK e BRYAN, 2002; KAATZ et al, 2002; BEQUEST TOOLKIT, 2004).

O Bequest Toolkit apresenta uma estrutura para mapear as ferramentas de avaliação de sustentabilidade (Figura 28) e uma lista com a caracterização dos métodos estudados. A estrutura do Bequest cobre diferentes fases da atividade de construção civil, níveis espaciais e escalas temporais; e a classificação das dimensões (ambiental, social, econômica e institucional) é feita com base na UNWSD ${ }^{66}$, que acompanha a Agenda 21 (HUOVILA et al, 2001).

\footnotetext{
${ }^{62}$ HK-BEAM - Hong Kong Building Assessment Method

${ }^{63} \mathrm{HQE}$ - Haute Qualité Environnementale

${ }^{64}$ BEQUEST - Building Environmental Quality Evaluation for Sustainability Through Time Network

${ }^{65} \mathrm{CIE}$ - Community Impact Evaluation

${ }^{66}$ UNWSD - United Nations Working list of Indicators of Sustainable Development
} 


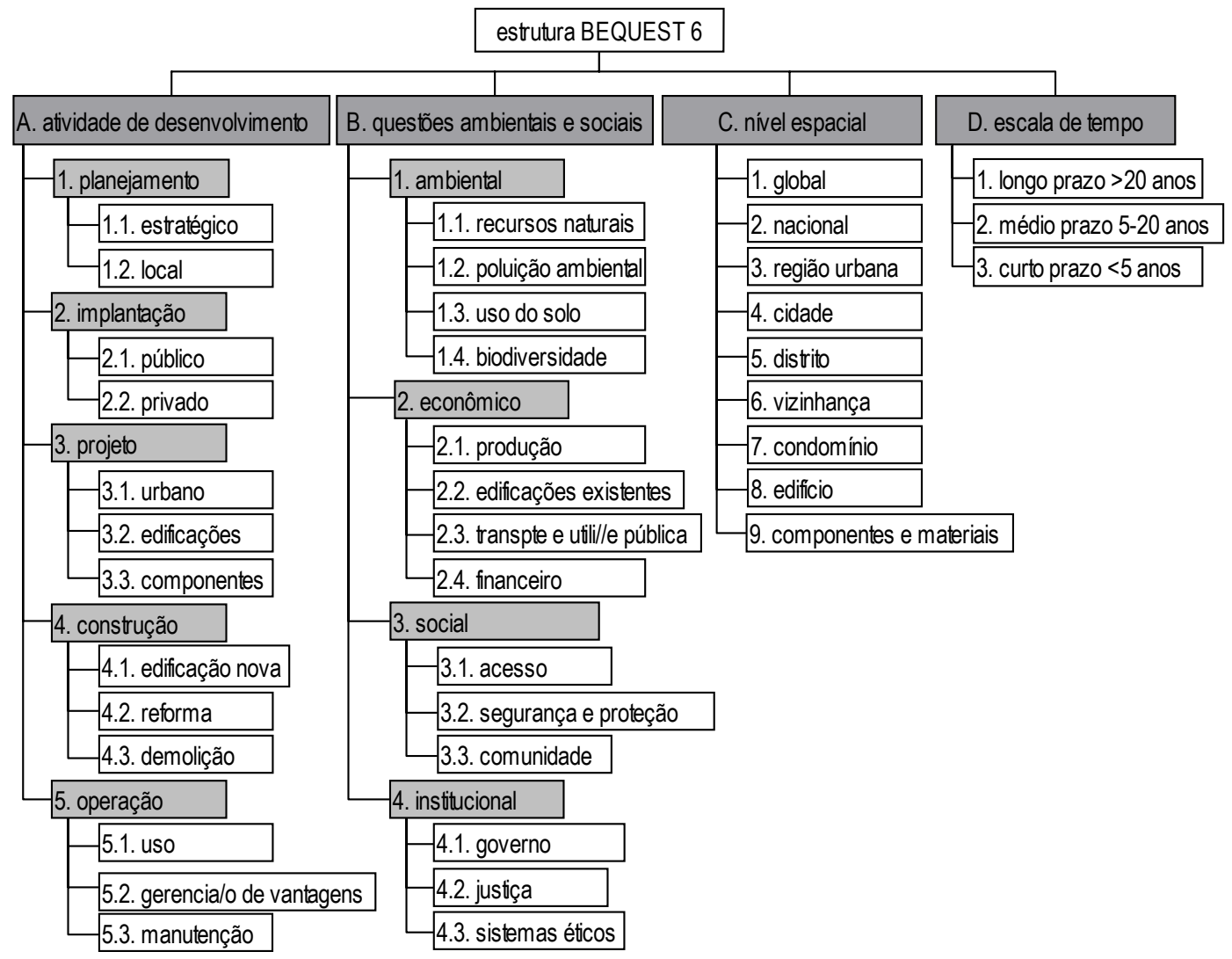

Figura 28. A estrutura do Bequest. fonte: traduzido de BEQUEST Toolkit (2004)

\begin{tabular}{|c|c|c|c|c|c|}
\hline & & planejamento & projeto & construção & operação \\
\hline \multirow{4}{*}{$\begin{array}{l}\text { questões de } \\
\text { desenvolvimento } \\
\text { sustentável }\end{array}$} & ambiental & & & & \\
\hline & econômico & & & & \\
\hline & social & & & & \\
\hline & institucional & & & & \\
\hline \multirow{6}{*}{ nível espacial } & cidade-região & & & & \\
\hline & distrito & & & & \\
\hline & vizinhança & & & & \\
\hline & lote & & & & \\
\hline & edificação & & & & \\
\hline & componente & & & & \\
\hline \multirow{3}{*}{ escala de tempo } & longo & & & & \\
\hline & médio & & & & \\
\hline & curto & & & & \\
\hline
\end{tabular}

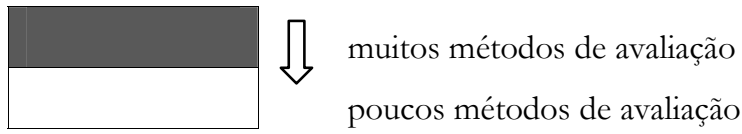

Figura 29. Esquema de análise Bequest Toolkit. fonte: traduzido de BEQUEST Toolkit (2004) 
Assim como mostra a Figura 29, há em geral, uma grande analogia entre os métodos existentes, quanto às questões tratadas, diferindo na sua forma de abordagem. Os métodos podem ser quantitativos, qualitativos ou ambos.

Boonstra e Pettersen (2003) observam que o desenvolvimento de ferramentas foi mais bem sucedido em países onde governo, investidores, arquitetos e especialistas em ciclo de vida desenvolveram uma linguagem e indicadores comuns, trabalhando em rede (como no GBTool). Mas essa ainda não é a tendência geral; e a grande quantidade de métodos de avaliação de sustentabilidade existentes, cada qual com as suas deficiências, indica a falta de cooperação entre os profissionais relacionados com a construção civil para a construção de um único método que considere todo o conjunto de questões (BAKENS, 2003, SILVA, 2002).

Assim, são comuns os problemas de terminologia, estabelecendo a dificuldade de comparação entre métodos e o risco de interpretações equivocadas (ASSEFA, 2002).

À parte a questão sobre a validade de discutir a relevância das questões de sustentabilidade, remetendo novamente à característica de "indissociabilidade" identificada por Silva e Shimbo (2001), a diversidade de trabalhos também gera problemas de ponderação (ou atribuição de pesos), já que para cada pesquisa é comum a elaboração de sistemas únicos de créditos e critérios, muitas vezes incomparáveis.

Silva et al (2003) apontam a complexidade da ponderação de forma objetiva e consistente. Os autores dizem que no LEED a ponderação não é explícita, uma vez que os pesos são definidos através do consenso entre os membros da equipe de desenvolvimento do sistema, o que dificulta a obtenção de resultados objetivos. O mesmo ocorre com o método das preferências ambientais e o BREEAM. Além disso, os métodos que se baseiam na obtenção de uma nota global (LEED e BREEAM) apresentaram o problema do mascaramento de aspectos negativos por outros positivos. Boonstra e Pettersen (2003) chamam a atenção para a possibilidade de sub-consideração das questões realmente relevantes.

Nesse ponto, o BEES é o que apresenta a estrutura mais transparente, por ser embasado em normas e por propor uma análise quantitativa. Por sua vez, a análise feita pelo método do BEES requer grande esforço de viabilização por demandar significativa quantidade de dados detalhados sobre cada uma das etapas do ciclo de vida dos materiais. Sperb (1999) 
comenta que dentre os métodos analisados em sua dissertação, esse foi o único que proporcionou o cálculo de valores absolutos de inputs e outputs, obtidos através do uso de fórmulas matemáticas.

Os métodos qualitativos (LEED, BREEAM, EBN, preferência ambiental, GBD) de um modo geral podem ser criticados pelas abordagens genéricas, falta de sistematização e de padrões. Sperb (1999) comenta o método das preferências ambientais: "muitas vezes, as comparações realizadas entre os quatro níveis de preferência não seguem o mesmo critério de avaliação, ficando algumas vezes confuso para o leitor”. No livro de Anink et al. (1996) de fato são apresentados somente os resultados das análises dos materiais de construção, com apenas algumas considerações para justificar as decisões tomadas.

No caso dos trabalhos baseados no desenvolvimento de indicadores, a dificuldade para estabelecer os benchmarks se deve à falta de padrões para apoiá-los (STRAND e FOSSDAL, 2003), o que deverá ser reduzido à medida do reconhecimento dos padrões ISO.

O critério para definir a relevância das questões ambientais é definido em muitos métodos de acordo com a preferência da maioria, seja de pesquisadores envolvidos ou de profissionais entrevistados (GBTool e BREEAM, por exemplo). Silva et al (2002) consideram a facilidade de utilizar tal procedimento, mas como isso nem sempre reflete a realidade, Glaumann, Assefa e Kindembe (2002) propõem que o critério seja dado pela avaliação dos danos causados no ambiente e nos seres humanos.

A especificidade dos países em desenvolvimento, quanto aos benchmarks e um sistema de ponderação mais adequado também devem então ser considerados nessa discussão (KAATZ et al, 2002, SILVA et al, 2002).

É o que propõe Silva et al (2002) para o desenvolvimento de um sistema de avaliação ambiental para o contexto brasileiro. Dizem que um modelo baseado no LCA, apesar de demandar muito trabalho, seria o mais adequado, para estimular o desenvolvimento de uma base de dados. A estrutura seria baseada em uma série de pré-requisitos complementada por créditos ambientais e créditos de bônus para atrair "uma contínua melhoria do sistema convertendo bônus em créditos e créditos em pré-requisitos". Para a ponderação, citam questões a serem adequadas:

- a emissão de gás carbônico durante o uso da edificação é menos importante no Brasil porque essa questão é devida aos sistemas de aquecimento e com matriz de energia à base de combustíveis fósseis dos países de clima frio; 
- medidas de incentivo parecem ser mais adequadas nas fases iniciais da construção para posteriormente converterem-se em critérios de desempenho;

- pela falta de referências de desempenho e dados ambientais, o grau de detalhamento da avaliação nacional seria menor do que em métodos como o LEED;

- a importância da inclusão de um plano de manutenção ou de um manual para o usuário na avaliação, num contexto em que a responsabilidade técnica é limitada ao processo de projeto ou ao final da construção.

Analisando a estrutura dos participantes para a elaboração dos métodos, observa-se uma tendência positiva à inclusão de mais agentes nos processos e àqueles com maior governabilidade. Huovila et al observam a participação de órgãos de governo na elaboração dos métodos CASBEE (Japão) e NABERS (Austrália). É observada também a tendência nos métodos mais recentes de direcionarem-se para as etapas cruciais de tomada de decisões (estudo preliminar, gerenciamento e operação das edificações).

Os métodos mais recentes definem uma escala geográfica a ser trabalhada, em prol do detalhamento da análise. Geralmente a avaliação é feita sobre as edificações, dos quais a avaliação dos materiais utilizados é uma parte. Mesmo nos métodos com escala de abrangência maior, há alguma consideração em relação aos materiais, sob o tópico "recursos naturais".

O Bequest Toolkit e Boonstra e Pettersen analisam que das edificações, a fase de projeto e uso são as mais analisadas, sendo a produção dos materiais e componentes menos abordados. Construção, manutenção e planejamento local recebem menor atenção e o “planejamento estratégico praticamente não é abordado” (HUOVILA et al, 2001).

Além das fases do ciclo de vida, o conjunto de questões de cada dimensão também é analisado separadamente em todos os métodos. Não foi identificada integração inter e nem intradimensões e todas as questões são apresentadas em paralelo, simplificando demasiadamente a complexidade das relações entre as questões de sustentabilidade.

A partir desse contexto, é possível compreender como os métodos de avaliação de sustentabilidade se desenvolveram de forma tão desequilibrada, focalizando preponderantemente apenas uma das dimensões - a ambiental.

Diferentemente das outras dimensões, o tratamento das questões ambientais vem se aprimorando continuamente. Em 1999, SPERB comentava que os métodos estudados (GBD, preferências ambientais e BEES entre outros) tinham uma abordagem genérica e 
superficial, constituindo-se no levantamento de alguns poucos aspectos de todo o ciclo de vida dos materiais, de forma não detalhada.

As metas atuais para Boonstra e Pettersen são, mais do que aplicar boas práticas, o estabelecimento de uma relação maior entre as questões ambientais globais e os impactos causados pelas edificações. Nas etapas de manutenção e gerenciamento das edificações, sugerem a incorporação das metas ambientais de escala global, nacional, regional e local, em curto, médio e longo prazo.

Seguindo essa mesma abordagem avançada em relação à visão tradicional das questões ambientais, Kolluru (1994) sugere um guia de conduta para os decisores com conceitos e estratégias para a formulação de políticas e outras práticas (Quadro 27).

\begin{tabular}{|c|c|}
\hline visão tradicional de desempenho ambiental & visão inovadora de desempenho ambiental \\
\hline controle da poluição & \multirow{3}{*}{$\begin{array}{l}\text { investimento de capital em longo prazo para } \\
\text { prevenção, renda e vantagem competitiva }\end{array}$} \\
\hline tratamento no final do processo & \\
\hline custos mínimos necessários & \\
\hline adendo incômodo no plano de negócios & $\begin{array}{l}\text { parte integral de um processo de planejamento } \\
\text { estratégico, às vezes fortalecido por um } \\
\text { pensamento de ciclo de vida }\end{array}$ \\
\hline preocupação com a eficácia & aumento da eficiência \\
\hline $\begin{array}{l}\text { programas para água, ar e solo } \\
\text { compartimentados }\end{array}$ & abordagem unificada \\
\hline táticas de comando e controle e confronto & $\begin{array}{l}\text { incentivos baseados no mercado e cooperação } \\
\text { entre agentes }\end{array}$ \\
\hline padrões baseados na tecnologia & $\begin{array}{l}\text { combinação de padrões baseados na tecnologia } \\
\text { e saúde }\end{array}$ \\
\hline políticas centradas nos humanos & $\begin{array}{l}\text { políticas de proteção aos recursos ecológicos } \\
\text { como um todo, independentemente do seu } \\
\text { valor econômico para os humanos }\end{array}$ \\
\hline
\end{tabular}

Quadro 27. Diferenças entre a visão tradicional e a inovadora de desempenho ambiental. fonte: traduzido e adaptado de Kolluru (1994, p. XV).

A análise dos dados obtidos nesse Capítulo mostra que, apesar do aumento das preocupações com princípios de outras dimensões além da ambiental, tal preocupação não se reflete nos métodos de avaliação de sustentabilidade.

A observação desses métodos mostra que mesmo os que se denominam "pluridimensionais" utilizam inadequadamente o termo. A dita "integração de aspectos ambientais, sociais e econômicos" apresenta na maioria das vezes apenas uma ou duas 
questões das dimensões social ou econômica. Geralmente são as questões de "saúde no ambiente interno", "custo iniciais" e "segurança". "Acessibilidade universal" e "aceitação das unidades habitacionais" pelos moradores são analisados somente por alguns métodos. Tratadas dessa forma, as questões de sustentabilidade não refletem o pensamento de "sistemas" de Bertalanffy.

Sejam baseados na LCA ou em indicadores, os resultados tipicamente obtidos pelos métodos apresentados são:

- o melhor material a ser escolhido - classificação;

- a melhor habitação construída - classificação;

- previsão de impacto do material - desempenho;

- previsão de impacto da habitação - desempenho;

- status do impacto do material utilizado - desempenho;

- status do impacto da habitação - desempenho;

- a melhor composição para a habitação - desempenho.

O maior problema identificado é a tentativa de pontuar ou eleger os "melhores materiais", não oferecendo ao usuário a visão sistêmica da análise e nem a necessária busca pela pluridimensionalidade numa análise de sustentabilidade. A utilização de softwares também contribui para ocultar as escolhas intermediárias.

Kaatz et al (2002) concluem que o SBAT oferece uma nova abordagem pela inclusão eqüitativa das dimensões econômica e social numa análise que é tradicionalmente ambiental. De fato, nesse método é perceptível a ampliação da gama de questões que interferem na sustentabilidade de um determinado contexto, com a vantagem de ser direcionada para países em desenvolvimento.

Mas, nem esse método garante a visão do tipo de integração apresentada por Leroy et al (2002), que conjuga mais dimensões da sustentabilidade por seguir o encadeamento dos fatos históricos do contexto nacional, numa abordagem diferenciada, que não se propõe à reprodução. São apresentadas as relações entre:

- concentração de renda, a desigualdade social e o aumento da pobreza;

- degradação ambiental e social (na cidade e campo);

- dívida externa e subordinação aos credores internacionais; 
- abertura dos mercados brasileiros à competição internacional e os impactos na economia, sociedade e meio ambiente;

- degradação da democracia e mercantilização da política.

Cada uma dessas discussões tem seus efeitos analisados nas outras dimensões da sustentabilidade, traçando a necessária visão sistêmica para a compreensão do contexto e embasamento de soluções que de fato rumem para a sustentabilidade.

Analisando a função, os sistemas de avaliação baseados em indicadores têm como questões centrais (SILVA et al, 2003):

- a identificação dos itens a serem medidos;

- a seleção de seus indicadores e o sistema de ponderação;

- a definição dos níveis de referência ou benchmarks e das metas de desempenho.

Implica em grande parte num processo de conhecimento e desenvolvimento de meios para acompanhar o andamento do item estudado. Ainda são reconhecíveis as funções de quantificação (modelos quantitativos) simplificação e de comunicação (acompanhamento das mudanças ao longo do tempo, tendências dos fenômenos). A objetividade, as possibilidades de repetição e de comparação com outros contextos (nacionais e internacionais) são outras características também ressaltadas por Häkkinen (2001).

Analisando o conjunto de métodos de avaliação de sustentabilidade apresentados nesse item, podem ser identificados os seguintes objetivos:

\begin{tabular}{|l|l|}
\hline \multicolumn{1}{|c|}{ objetivo } & \multicolumn{1}{c|}{ objetivos secundários } \\
\hline \hline $\begin{array}{l}\text { compreender os } \\
\text { elementos da dinâmica } \\
\text { do contexto }\end{array}$ & $\begin{array}{l}\text { identificar os elementos: } \\
-\quad \text { fatores impactantes } \\
-\quad \text { melhores práticas }\end{array}$ \\
\hline $\begin{array}{l}\text { quantificar os impactos ou quaisquer outros dados qualitativos } \\
\text { somunicar/ informar a situação do } \\
\text { desempenho ambiental }\end{array}$ & $\begin{array}{l}\text { simplificar/ popularizar os dados } \\
\text { explicitar a situação atual } \\
\text { monitorar o desenvolvimento do evento analisado } \\
\text { explicitar a tendência à maior ou menor sustentabilidade } \\
\text { servir de base para a tomada de decisões }\end{array}$ \\
\hline
\end{tabular}

Quadro 28. Objetivos comuns dos métodos de avaliação ambiental 
A principal lacuna identificada é a ausência de métodos para compreender a dinâmica do contexto. Por isso, seguindo a mesma estrutura dos objetivos identificados no item anterior, propõe-se a inclusão da "identificação da dinâmica" como mais um dos objetivos das avaliações de sustentabilidade, conforme apresentado abaixo:

\begin{tabular}{|l|l|}
\hline \multicolumn{1}{|c|}{ objetivo } & \multicolumn{1}{c|}{ objetivos secundários } \\
\hline \hline $\begin{array}{l}\text { compreender a } \\
\text { dinâmica do contexto } \\
\text { e seus elementos }\end{array}$ & $\begin{array}{l}\text { identificar a dinâmica } \\
-\quad \begin{array}{l}\text { quais são os processos que geram impactos } \\
\text { ganhos e perdas de sustentabilidade, atribuir pesos } \\
\text { (ponderação)/ importância das relações, selecionar } \\
\text { indicadores, atribuir pesos aos indicadores definição de níveis } \\
\text { de referência ou benchmarks, definição de metas de } \\
\text { desempenho, definir o equilíbrio entre ideal e o possível) }\end{array}\end{array}$ \\
\hline $\begin{array}{l}\text { compreender os } \\
\text { elementos da dinâmica } \\
\text { do contexto }\end{array}$ & $\begin{array}{l}\text { identificar os elementos: } \\
\text { fatores impactantes } \\
-\quad \text { melhores práticas }\end{array}$ \\
\hline $\begin{array}{l}\text { comunicar/ informar } \\
\text { sobre a situação do } \\
\text { desempenho ambiental }\end{array}$ & $\begin{array}{l}\text { quantificar os impactos ou quaisquer outros dados qualitativos } \\
\text { simplificar/ popularizar os dados } \\
\text { uniformizar os dados produzidos } \\
\text { explicitar a situação atual } \\
\text { monitorar o desenvolvimento do evento analisado } \\
\text { explicitar a tendência à maior ou menor sustentabilidade } \\
\text { servir de base para a tomada de decisões }\end{array}$ \\
\hline
\end{tabular}

Quadro 29. Proposição para os objetivos das avaliações de sustentabilidade

O objetivo de mostrar a dinâmica do contexto analisado é:

- identificar a teia de interações (lineares e não lineares);

- o que são as prioridades de ação para a sustentabilidade de uma região - busca de soluções para os antecedentes (causas) e não para as respostas (efeitos) ou suas conseqüências;

- gerar no decisor a capacidade preditiva do comportamento do contexto.

Assim, o resultado de uma análise mais plural e inter-relacionada das dimensões da sustentabilidade exploraria: 
- as relações entre dimensões e entre processos da cadeia produtiva;

- como cada questão repercute nas outras questões;

○ ganhos e perdas de sustentabilidade em uma dimensão;

○ ganhos e perdas de sustentabilidade entre as dimensões.

- cenários de maior e de menor sustentabilidade.

O Capítulo 4 é desenvolvido objetivando a obtenção desses resultados, associando, para tanto, os dados obtidos nos Capítulos anteriores. Entende-se que dessa forma possa ser obtida uma primeira aproximação da abordagem mais ampliada da cadeia produtiva da habitação em madeira de plantios florestais, mencionada no final do Capítulo anterior. 


\section{CAPITULO 4}

\section{A DERIVAÇ̃̃̃ DAS CARACTERISTIICAS DA SUSTENTABILIDADE PARA A ANÁLISE DA CADEIA PRODUTIVA DA HABITACÃ̃O EM MADEIRA DE PLANTIOS FLORESTAIS}

A análise do Capítulo anterior mostra que para trabalhar adequadamente a sustentabilidade é necessário entender o processo dinâmico de ganhos e perdas de sustentabilidade. E uma vez que essas interações não ocorrem somente dentro de cada processo, é necessário entender os elos pluridimensionais que ocorrem entre processos.

Complementar ao Capítulo 1, que buscou abordar os ganhos e perdas de sustentabilidade (ainda que prioritariamente em uma dimensão - ambiental), neste Capítulo, o propósito é explicitar, no contexto da cadeia produtiva analisada, as relações entre os processos e entre dimensões provenientes das discussões da construção sustentável, compreendendo:

- as interações da rede de questões da cadeia produtiva;

- como cada questão repercute nas outras questões,

- os ganhos e perdas de sustentabilidade entre as dimensões e

- o quão interfere cada ação na busca da sustentabilidade.

\subsection{Caracterização do objeto empírico - o contexto do Projeto de Políticas Públicas}

A escolha da Região Sudoeste do Estado de São Paulo para a realização do Projeto de Políticas Públicas "Habitação de interesse social em madeira de reflorestamento como alternativa econômica para usos múltiplos da floresta”, apoiado pela FAPESP se deveu, conforme já anunciado na Introdução, à disparidade entre o potencial econômico com base nas florestas plantadas e os baixos indicadores sociais dos seus municípios. 
Por isso, o Projeto teve como objetivo a elaboração de diretrizes para políticas públicas nas áreas de reposição florestal, geração de trabalho e renda e produção de habitação, com base na condução de variadas estratégias que buscaram atender aos princípios de sustentabilidade.

Neste item é apresentado um breve histórico do desenvolvimento desse Projeto, de maneira a subsidiar a compreensão dos elos analisados no item a seguir.

\subsubsection{Histórico do projeto}

O Projeto de Políticas Públicas teve duas fases de execução:

- Fase I: nove meses - novembro de 1999 a julho de 2000

- Fase II: trinta e sete meses - julho de 2001 a agosto de 2004

Durante a Fase I do projeto, as estratégias voltaram-se para a criação e fortalecimento de parcerias para o desenvolvimento do projeto, identificando as suas dificuldades e potencialidades.

Nessa fase, foram coletados dados sobre a demanda por habitação tanto na área urbana (Tabela 11) como na rural (Tabela 12) da Região Sudoeste do Estado de São Paulo e sobre as condições das habitações atuais(Figura 30).

Tabela 11. Demanda habitacional urbana - Região Sudoeste de São Paulo

\begin{tabular}{l|c|c|c|c|} 
& Itapeva & Itararé & Itaberá & Buri \\
\hline Número de famílias & 23.118 & 12.638 & 5.406 & 4.566 \\
\hline Número total de habitações & 19.631 & 11.045 & 4.456 & 3.419 \\
\hline Déficit habitacional & 3.487 & 1.593 & 950 & 1.147 \\
\hline Favelas & 214 & 547 & 72 & 53 \\
\hline Cortiços & 28 & 15 & 19 & --- \\
\hline Déficit habitacional total & 3.729 & 2.155 & 1.041 & 1200
\end{tabular}

fonte: IBGE/SEADE CENSO 1991 apud INO et al (2000)

Tabela 12. Demanda habitacional rural - Ass. Rural Faz. Pirituba - Agrovilas 1,2,3,4,5 e 6.

\begin{tabular}{c|c|c|c|c|c}
\hline população & $\mathrm{n}^{\circ}$ de famílias & total de habitações & unidades precárias & $\begin{array}{c}\text { famílias sem } \\
\text { moradia }\end{array}$ & demanda habitacional \\
\hline 1909 & 361 & 356 & 91 & 6 & 97 \\
\hline fonte: ITESP 1998 apud INO et al (2000)
\end{tabular}




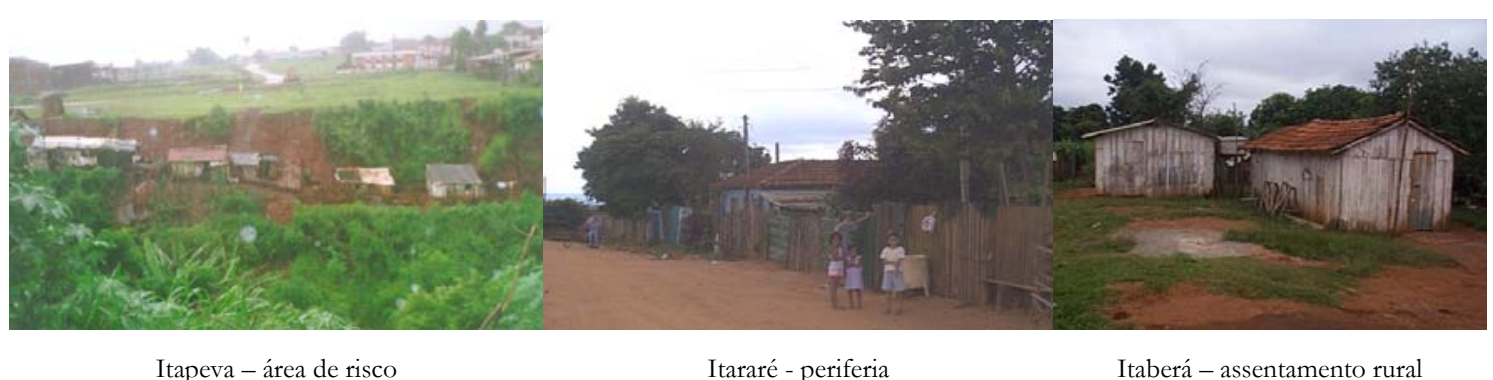

Figura 30. Características gerais das habitações precárias em Itapeva, Itararé e Itaberá. Fonte: INO et al (2000)

Outras atividades executadas na Fase I:

- definição das glebas para a implantação dos conjuntos habitacionais, como expectativa de continuidade do Projeto na Fase II;

- avaliação do potencial florestal para construção habitacional no município e região;

- $\quad$ avaliação do potencial industrial madeireiro local (Tabela 13 e Figura 31);

- análise das parcerias e estratégias adotadas;

- estudos preliminares de sistemas construtivos (Figura 32);

- identificação de linhas de financiamento possíveis.

Tabela 13. Quantidade de serrarias na região em 1997

\begin{tabular}{l|c}
\hline \multicolumn{1}{c|}{ cidade } & número de empresas \\
\hline Itapeva & 50 \\
\hline Itararé & 14 \\
\hline Ribeirão Branco & 12 \\
\hline Capão Bonito & 10 \\
\hline Apiai / Nova Campina & 06 \\
\hline Bom Sucesso de Itararé & 05 \\
\hline Itaberá / Taquarivaí / Guapiara & 04 \\
\hline Buri & 03 \\
\hline Ribeirão grande/ Riversul & 01 \\
\hline TOTAL & 120 \\
fonte: Sebrae - SP - Agência Itapeva/ 1997
\end{tabular}




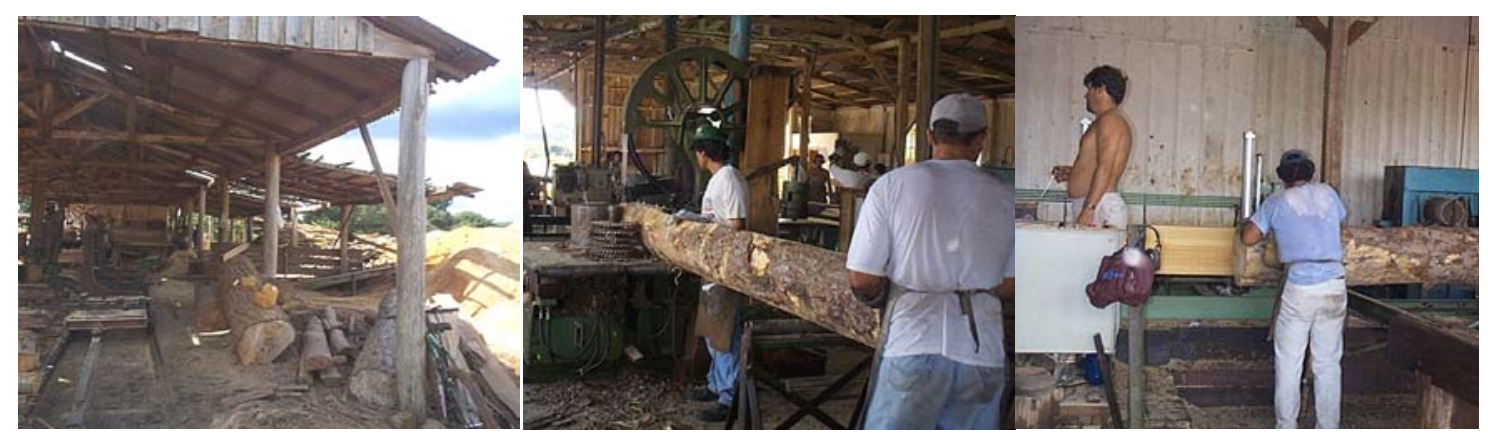

Figura 31. Condições inadequadas típicas de serrarias de pequeno porte fonte: INO et al (2002)

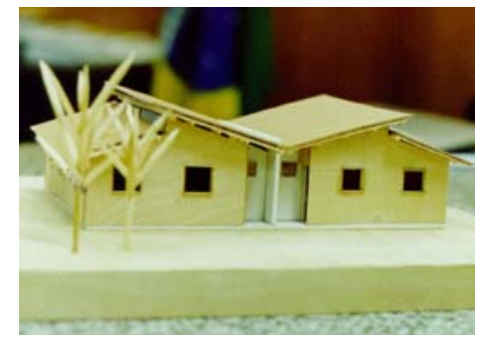

(a) unidades geminadas

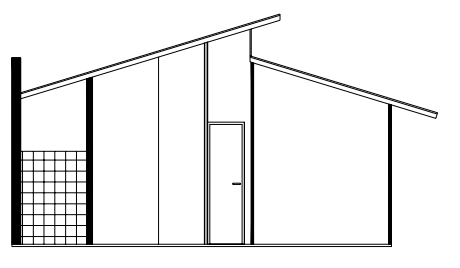

(b) corte

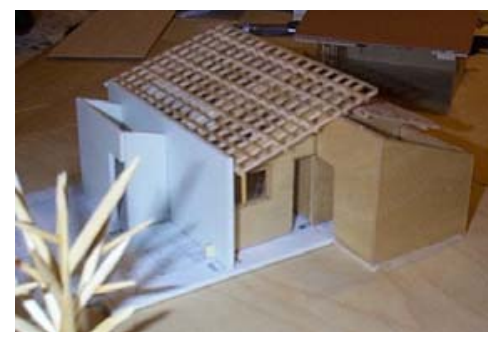

(c)

Figura 32. Estudos de sistemas construtivos utilizando madeira de plantios florestais da região fonte: INO et al (2002)

$\mathrm{Na}$ conclusão da Fase I, foram definidas:

- parceria com a Prefeitura Municipal de Itararé para produção de 50 unidades habitacionais em área urbana, com gleba definida;

- $\quad$ parceria com ITESP ${ }^{67}$ para produção de 20 unidades habitacionais em área rural;

- parceria entre SEBRAE Itapeva e UNESP Bauru para projeto de otimização de serrarias da região de Itapeva (2001 a 2002).

Finalizada a Fase I, após um ano, foi aprovada a continuidade do Projeto, com a Fase II (2001 - 2004). O primeiro momento dessa fase foi de tentativa de recuperação das parcerias que haviam sido delineadas na Fase I.

$\mathrm{Na}$ atualização, novas demandas foram incluídas com vistas aos usos múltiplos da madeira (móveis, componentes de habitação, esquadrias, artesanato e pequenos artefatos) e houve 
mudança de estratégias, com análise das metas propostas e conseqüente manutenção ou cancelamento.

Novos projetos foram elaborados para a busca de financiamentos mas, devido às dificuldades enfrentadas para a manutenção do Grupo Gestor - variação no número de participantes, insconstância de presença nas reuniões, falta de comprometimento com o desenvolvimento das atividades - analisadas no Relatório Parcial do Projeto (INO et al, 2002), houve uma paulatina perda de motivação para a continuidade do Projeto em Itararé.

Dado o andamento não satisfatório e o surgimento de novas demandas, o objeto empírico do Projeto de Políticas Públicas foi transposto para o Assentamento Rural Fazenda Pirituba, em Itapeva (INO et al, 2004), passando a trabalhar diretamente com a população interessada, entre usuários das habitações e aqueles com foco na criação de empreendimentos relacionados à cadeia produtiva da madeira de plantios florestais, diferentemente da forma conduzida em Itararé.

Essa nova forma de abordagem tem gerado resultados mais significativos para a população local, como a obtenção de financiamento habitacional para a construção de 49 unidades, inseridos no Programa de Subsídio à Habitação de Interesse Social (PSH), convênio Caixa Econômica Federal (CEF) e Instituto de Colonização e Reforma Agrária (INCRA).

\subsubsection{Estratégias adotadas para a sustentabilidade}

A estratégia geral adotada na Fase I, visando a sustentabilidade política e econômica do Projeto, foi o envolvimento e aumento da participação dos agentes da cadeia produtiva (reflorestadores, serrarias, sindicatos de trabalhadores, sindicatos do setor florestal e madeireiro), associações comunitárias, representantes do poder público local e da comunidade interessada na consolidação e desenvolvimento da cadeia produtiva da madeira, tendo em vista um novo modelo de gestão.

Nesse processo, em Itararé, foi criado o Grupo Gestor, responsável pela identificação de oportunidades, elaboração e condução de estratégias que contribuíssem nesse sentido. Todas as ações, inclusive a própria formação do grupo objetivavam a capacitação para garantir a manutenção do projeto.

A Figura 33 mostra um mapa cognitivo do Projeto (julho de 2000), elaborado em conjunto com o Grupo Gestor de Itararé. 


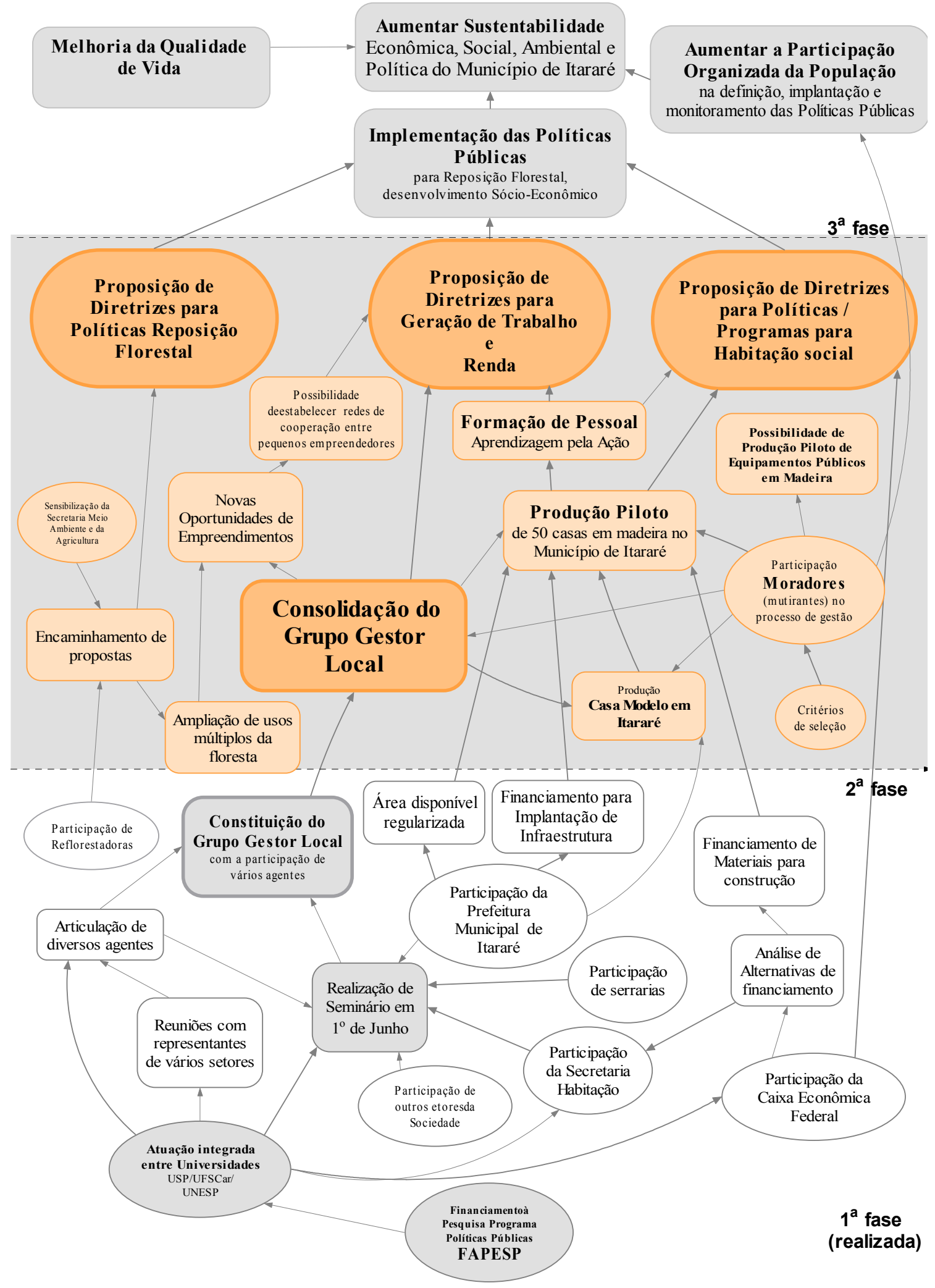

Figura 33. Mapa cognitivo do Grupo Gestor em Itararé - Fase I fonte: INO et al (2002) 


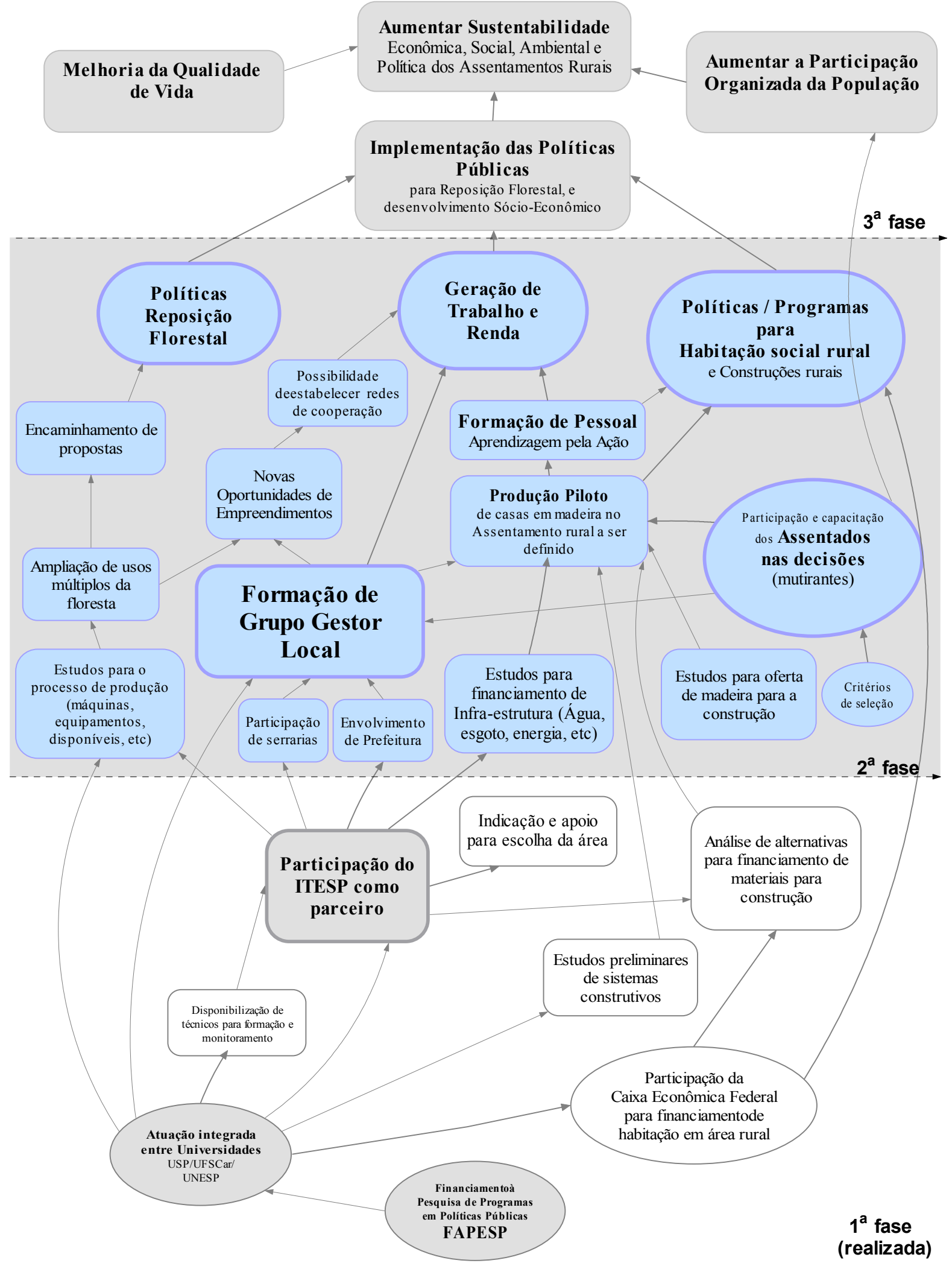

Figura 34. Mapa cognitivo para assentamentos rurais - Fase I fonte: INO et al (2002) 
O diagnóstico das potencialidades de desenvolvimento do Município de Itararé (SEBRAE/SP, 2000) apresenta princípios similares para o desenvolvimento e consolidação da cadeia produtiva da madeira: o fortalecimento das iniciativas que apóiam e acreditam na realização do pólo em Itararé, o encorajamento das ações de aprendizagem para o beneficiamento da madeira, a formação de mão-de-obra e a implantação de escola técnica específica, com a participação da Prefeitura local, as universidades, órgãos financiadores e o Governo Estadual como indutores desse processo.

Buscando um reforço mútuo entre estratégias dos projetos em andamento, verificou-se que a consolidação da cadeia produtiva poderia estar aliada com o desenvolvimento das outras potencialidades identificadas pelo Diagnóstico: desenvolvimento do turismo, artesanato, melhoria da produtividade rural, capacitação gerencial do setor de comércio e serviços, melhoria das condições de vida da população nas áreas de habitação, saúde, educação e profissionalização. 


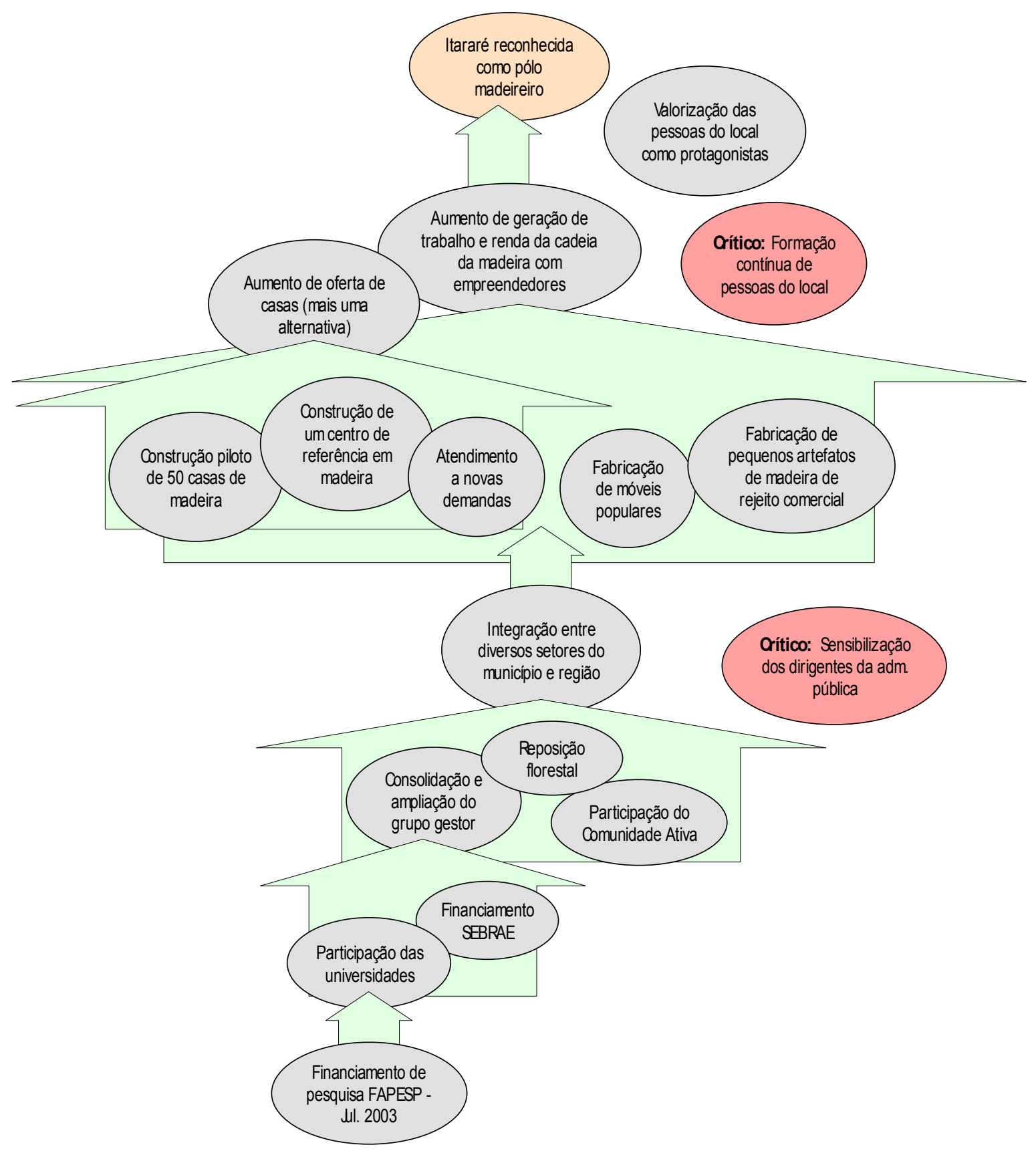

Figura 35. Mapa cognitivo do Projeto de Políticas Públicas - Fase II fonte: INO et al (2002)

Com a inviabilização do Projeto em Itararé e a transferência das atividades do Projeto para Itapeva, no Assentamento Rural Fazenda Pirituba, as estratégias foram alteradas, em torno da meta de produção de habitação para 49 famílias. A estratégia geral é a promoção da participação/capacitação dos usuários em todas os processos decisórios:

- desenvolvimento do projeto arquitetônico; 
- escolha do sistema construtivo e dos materiais;

- $\quad$ articulação para obtenção de financiamento habitacional;

- $\quad$ aquisição e distribuição de materiais;

- construção das habitações em regime de mutirão.

Outras estratégias adotadas no Assentamento Rural Fazenda Pirituba são:

- projeto e execução de casa-modelo;

- projeto para reposição florestal no assentamento rural - Projeto TUME (Teste de Usos Múltiplos do Eucalipto), visando a descentralização da produção florestal;

- implementação de marcenaria coletiva autogestionária para a produção de componentes construtivos em madeira, como alternativa para geração de trabalho e renda na cadeia de produção de habitação;

- produção de habitação com materiais locais e renováveis (adobe e madeira de pinus e eucalipto)

\subsection{Uma visão dos elos entre os processos da cadeia produtiva da habitação em madeira de plantios florestais}

A visão de cadeia produtiva é mais vantajosa para a sustentabilidade porque pré-determina a existência de "elos". E, com base na exploração desses elos que se pretende abordar as características de pluralidade e indissociabilidade do conceito que não estão sendo ainda consideradas nos métodos de avaliação de sustentabilidade e nem na forma de pesquisa tradicional sobre a madeira de plantios florestais como material de construção de habitações.

A Figura 36 apresenta elos entre os processos da cadeia produtiva, provenientes da análise de literatura do Capítulo 1 e das observações do contexto da Região Sudoeste do Estado de São Paulo, reforçadas pela busca da inserção da discussão apresentada nos Capítulos 2 e 3.

$\mathrm{O}$ atendimento aos princípios da sustentabilidade nem sempre representa apenas ganhos de sustentabilidade para todas as dimensões, podendo haver relações de ganhos e perdas entre dimensões nos elos formados. 


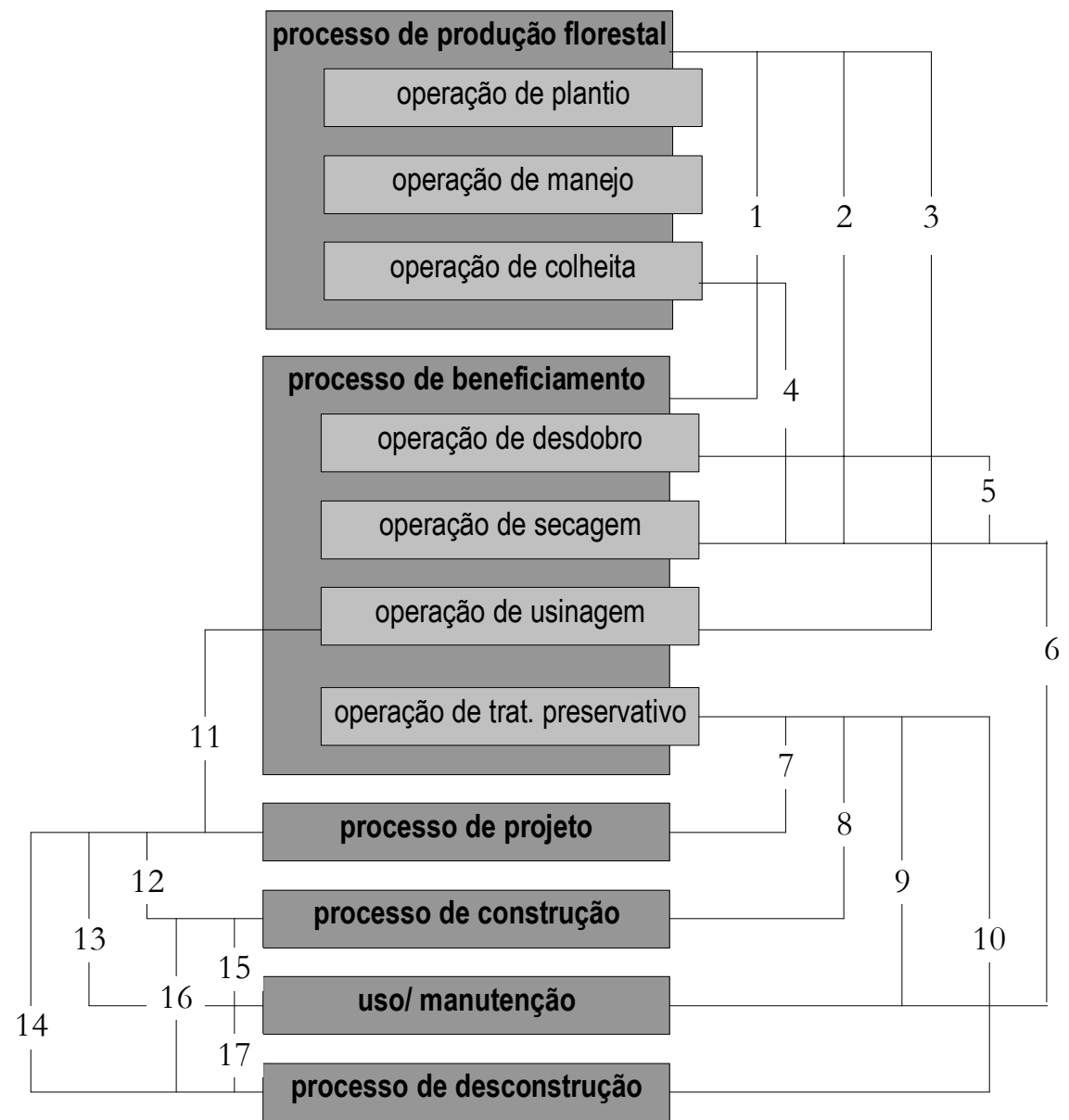

Figura 36. Elos entre processos na cadeia produtiva da habitação em madeira de plantios florestais.

Elo 1: produção florestal e processo de beneficiamento - a aquisição de madeira proveniente de produtores que atendem aos princípios e critérios do FSC representa uma contribuição para aumentar a sustentabilidade, além de influenciar demais produtores a melhorar o manejo de seus plantios. Isso é facilitado pela existência de princípios ambientais e sociais claramente definidos para a sustentabilidade dos plantios florestais. Mas é preciso ressaltar que ainda é necessário desenvolver mecanismos que facilitem a obtenção das certificações por pequenos produtores florestais.

A dimensão ambiental ainda é contemplada porque conjuntamente com o manejo, a introdução de outros melhoramentos nos plantios florestais resulta em toras de melhor qualidade, contribuindo para a produção de peças com menos defeitos e conseqüentemente na menor produção de resíduos em todas as operações do processo de beneficiamento.

Mesmo considerando o atual cenário de geração de grande quantidade de resíduos, as ações já existentes de utilização de resíduos da floresta e do processo de beneficiamento como 
matérias-primas para a produção de componentes de habitação, contribuem para a dimensão social e econômica da construção sustentável, através da viabilização de produção a custos menores e a criação de atividades potencialmente geradoras de emprego.

Além das questões técnicas que relacionam esses dois processos, o contexto de Itararé mostra a concretização de um dos cenários estimados por Voinson e Castagné, que sugeriam o aumento gradual da concentração fundiária em torno de empresas florestais de grande porte.

O aumento dos preços da madeira que pôde ser acompanhado ao longo dos últimos anos, denota a influência desses empreendimentos sobre o desenvolvimento das cadeias produtivas que utilizam a madeira como matéria-prima. Iniciado com uma anunciada redução da oferta de madeira de plantios florestais, os preços médios no início de 1999 eram de $\mathrm{R} \$ 150,00 / \mathrm{m}^{3}$ de pinus serrado nas serrarias de Itararé e Itapeva e atualmente os preços mínimos encontrados são de $\mathrm{R} \$ 300,00 / \mathrm{m}^{3}$ para pinus de segunda categoria.

A expansão da produção florestal industrial que atende principalmente ao setor de papel e celulose, foi acompanhada ao mesmo tempo da redução da participação de pequenos produtores, prejudicando ainda mais o fornecimento alternativo de madeira no mercado de produtos serrados. Há também o percentual destinado ao atendimento ao mercado externo das grandes empresas de transformação, reduzindo ainda mais a oferta dessa madeira no país.

Esse cenário tende apenas a aumentar a situação de crise vivida pelas serrarias, marcenarias e outros empreendimentos dependentes da madeira na região, aumentando ainda mais as disparidades entre pequenas e grandes serrarias. Componente característico dessa diferença é a governabilidade sobre as etapas de transformação da matéria-prima em produto. Enquanto as pequenas serrarias são relacionadas à "mortalidade" dos empreendimentos, a falta de capacidade de investimento para o aprimoramento do processo de produção ou de seus produtos, desemprego e falta de políticas públicas, as grandes serrarias são verticalizadas, compreendendo muitas vezes da produção florestal à elaboração de produtos acabados, com tecnologia de ponta para o processamento e voltadas para o mercado externo.

A minimização desse cenário de tendência à insustentabilidade foi alvo dos esforços do início da Fase II do Projeto de Políticas Públicas e também do Programa Comunidade Ativa, conduzida pelo SEBRAE/SP, através do trabalho de capacitação de grupos mobilizados para o desenvolvimento sustentável do setor. 
Entendendo a interdependência entre sustentabilidade social e econômica, as estratégias adotadas pelo Projeto de Políticas Públicas defendem a descentralização da produção florestal, apoiando o aumento da participação de pequenos produtores florestais, cuja forma de produção contribui para a geração de uma segunda fonte de renda e para reduzir os impactos ambientais causados pelas grandes monoculturas.

Esse "reflorestamento social" é também visto por Lima como um meio de garantir a manutenção dos remanescentes de florestas naturais, reduzir o processo de degradação das bacias hidrográficas, deterioração da qualidade da água e perda da fertilidade do solo.

Nesse sentido, a base de dados do Inventário florestal necessita ser complementada com informações mais detalhadas sobre a classe "não identificadas" dos detentores de florestas do Estado, de quantidade significativa nos dados apresentados por Kronka (2002), além do estudo das razões que levaram à interrupção dos programas de plantios florestais, priorizando a produção pulverizada e evitando os problemas decorridos com os incentivos fiscais.

Lima considera ações econômicas e legais "imprescindíveis" na integração dos produtores rurais ao processo de produção florestal. As possibilidades citadas são os planos de custeio da atividade agrícola, alterações nas normas de licenciamento dos processos da cadeia produtiva florestal, programas de financiamento para pequenos produtores (como o Programa de plantio comercial de florestas - Propflor - e PRONAF Florestal).

Visando aumentar a participação da madeira de pinus no mercado de construção civil, Voinson e Castagné propõem a estratégia geral de introdução de novos produtos com qualidade para a conquista de novos mercados. O critério da qualidade é indispensável na tentativa de reduzir a rejeição dos usuários de produtos de madeira, principalmente para aqueles que já têm experiências anteriores negativas. $\mathrm{O}$ mesmo vale para os produtores de florestas, que não obtiveram bons resultados com plantios florestais anteriores, que necessitam além da capacitação, serem convencidos da viabilidade técnica e econômica de novos plantios.

A estratégia, para ter sucesso, considera a cooperação dos produtores florestais (inclusive os do setor de papel e celulose) para a seleção das toras de maior diâmetro para o setor de serrados. O setor de trituração seria beneficiado pelos preços mais baixos das toras de menor diâmetro, pela fonte de renda gerada pelo comércio das toras maiores e o aumento do suprimento de madeira proveniente dos subprodutos e resíduos de desdobro e laminação. 
O produto analisado pelos autores, o painel sarrafeado, se deve à possibilidade de utilização de subprodutos do desdobro e madeira de baixa qualidade, valorizando a matéria-prima e possibilitando a substituição de outros produtos no fim da cadeia produtiva da habitação em madeira (peças serradas, compensados e aglomerados).

Elo 2: produção florestal e operação de secagem - as inter-relações dos primeiros processos dessa cadeia produtiva são mais evidentes e vem sendo trabalhadas a mais tempo por se tratarem principalmente de aspectos tecnológicos. As especificidades tratadas em várias dessas pesquisas referentes às operações do processo de usinagem demandaram a particularização dos seus elos com o restante da cadeia produtiva.

Para a boa qualidade dos produtos de madeira de eucalipto serrado em termos de secagem, Trugilho et al (2002) dizem que a seleção e classificação de genótipos superiores que apresentam elevada herdabilidade de características favoráveis é a ação mais importante já que a qualidade inadequada para a produção de serrados das madeiras atuais se devem ao foco do seu mercado - papel e celulose e combustível para siderurgia.

Além da matéria-prima, em florestas implantadas a melhoria do trato silvicultural pode reduzir os defeitos de formação - presença de nós, veios de quino, conicidade e achatamento. E, por fim, o processamento e a mão-de-obra operacional e gerencial envolvida completam o conjunto dos principais fatores intervenientes nessa relação (Jankowsky apud Ducatti, Jankowsky e Andrade, 2001; GALVÃO, 1976; TRUGILHO et al, 2002).

Elo 3: produção florestal e operação de usinagem - o baixo índice de conversão das toras em produtos de alto valor agregado determina a prática de preços altos e a produção de grande quantidade de subprodutos e resíduos de madeira.

Para combater a falta de competitividade dos produtos de madeira no mercado em curto prazo, Voinson e Castagné em 1988 já consideravam a importância dos subprodutos do desdobro da madeira e dos resíduos da floresta (toco, ponta e metrinho). Visando a possibilidade de utilização de técnicas para elaboração de produtos a partir de toras de pequenas dimensões, laminados colados, painéis sarrafeados e madeira colada de topo (tipo finger joint) foram alternativas de produtos industriais citados por esses autores, mas que como solução, demandam um aporte de recursos para a montagem de uma unidade fabril. 
O aproveitamento desses subprodutos e resíduos envolve várias questões da sustentabilidade ao mesmo tempo. Há o desafio de reduzir a sua produção durante as fases do processamento, a busca de formas de aproveitamento em produtos de valor agregado, a possibilidade de geração de empregos e renda e a redução da poluição causada pela sua produção.

A destinação dos resíduos para usos como combustível é a mais comum das alternativas adotada pelas serrarias de Itararé. Outras também identificadas são a destinação para fabricação de papel, MDF e composto. Apesar de essas alternativas contribuírem para a questão da poluição ambiental, durante o Projeto de Políticas Públicas foi identificada a possibilidade de aproveitamento de pelo menos parte dos resíduos e subprodutos como matéria-prima para a fabricação de pequenos objetos (artesanato, utensílios domésticos), como forma de agregar mais valor e gerar mais empregos e renda nessa cadeia produtiva.

Para cada opção de uso ressaltam-se vantagens e desvantagens, assim como dimensões favorecidas e desfavorecidas, dependendo do contexto analisado. Os questionamentos que podem ser levantados para qualquer forma de aproveitamento são:

- retorno econômico e financeiro;

- logística necessária para o aproveitamento;

- existência de mercado consumidor;

- necessidade de articulação entre agentes da cadeia produtiva;

- adaptações do layout do processo de fabricação;

- custo;

- mão-de-obra envolvida.

Além das estratégias de curto prazo, ações de médio e longo prazo sobre o melhoramento dos plantios florestais também são requeridas para que esse elo resulte em mais relações positivas para a sustentabilidade.

Elo 4: operação de colheita e operação de secagem - ações específicas são determinadas para esse elo, com o objetivo de reduzir os possíveis defeitos de secagem. As considerações de Trugilho et al englobam o aumento do tempo de armazenamento das toras sob imersão total para reduzir as tensões internas de crescimento, o corte e toragem 
de árvores de Eucalyptus grandis com anelamento (AGUIAR e JANKOWSKY apud TRUGILHO et al, 2002), utilização de saco plástico para proteger as peças para amenizar a perda de água após o abate e o corte de toras em comprimentos maiores para reduzir as rachaduras de topo.

Elo 5: operação de desdobro e operação de secagem - a operação de desdobro também tem o seu elo com a secagem, cujo aumento de conhecimento poderia contribuir na redução de perdas (DEL MENEZZI, 1999). O desdobro rápido é considerado por Schact e Garcia apud Trugilho et al (2002) para reduzir as rachaduras de topo. O uso de método de corte simultâneo para aumentar a produtividade, a precisão e reduzir os empenamentos são analisados por Del Menezzi e Nahuz apud Trugilho et al, 2002, com a desvantagem de ser pouco flexível e produzir madeira de qualidade inferior, com medula e madeira juvenil.

A desorganização do setor contribui para o agravamento de vários problemas da cadeia produtiva, mesmo os técnicos, por meio do desconhecimento generalizado entre os agentes do processamento sobre as características da madeira. Isso faz com que sejam reproduzidos elos de desinformação similares ao longo de todos os processos, que resultam na baixa qualidade dos produtos e a grande produção de resíduos, por exemplo.

Elo 6: operação de secagem e uso - quando a operação de secagem é bem sucedida, a madeira é mais estável e as dilatações e deformações que ocorrem durante a fase de uso são menores. Ao mesmo tempo, como o conteúdo de umidade é baixo, torna-se menos suscetível ao ataque de fungos e insetos.

O usuário não capacitado para as características da madeira e para o processo de produção da habitação pode, em virtude de problemas técnicos como esse, aumentar a sua rejeição, atribuindo à madeira e não à técnica as causas dos problemas ocorridos.

A experiência de países desenvolvidos mostra que a demanda pela qualidade partida do usuário, tende a desenvolver a consciência para a sustentabilidade nos empreendimentos da cadeia produtiva, transformando-se num diferencial para aumentar a competitividade no mercado. 
Elo 7: operação de tratamento preservativo e processo de projeto - a sustentabilidade ambiental ganha com o aumento da durabilidade da habitação em madeira proporcionada pelo tratamento preservativo, mas também perde pela utilização de produtos tóxicos no seu processo. O Green Building Digest (1996) considera um paradoxo o "envenenamento" da madeira, um dos materiais de construção mais "saudáveis".

Visando não comprometer a durabilidade das habitações, a alternativa é aumentar a responsabilidade de outros processos da cadeia produtiva - processo de projeto e o uso. Assim como nesse, o projeto tem o papel de determinar o aumento ou a diminuição de sustentabilidade em vários elos. No tratamento preservativo, o projeto tem o papel de considerar a real necessidade de tratamento, determinar a quantidade de madeira tratada, a toxicidade e buscar alternativas menos tóxicas, para reduzir a liberação de emissões ambientalmente perigosas.

A análise dos princípios apresentados no Capítulo 2 indica que as estratégias mais adequadas estão na diminuição ou eliminação do uso de produtos tóxicos em detrimento da utilização racionalizada de produtos menos tóxicos, um cuidadoso detalhamento construtivo, a facilitação de inspeções e manutenção e também prevendo a substituição de peças deterioradas durante a fase de uso da habitação.

A compilação de Finger e Meili (2002) mostra que mesmo em situações de exposição permanente às intempéries, a durabilidade pode ser aumentada com um detalhamento e manutenção adequados, independentemente da utilização de tratamentos preservativos.

Também a pesquisa de produtos menos tóxicos pode ser incentivada, no qual riscos de deterioração podem ser pesquisados conjuntamente com os projetistas.

Elo 8: operação de tratamento preservativo e processo de construção - a construção sustentável também indica o aumento da responsabilidade dos fabricantes sobre os impactos ambientais provocados por seus processos e produtos. Por isso, é importante que na fase de construção, as peças tratadas sejam facilmente identificadas pelos trabalhadores, através de cores, etiquetas ou carimbos, informando o produto utilizado no tratamento e os procedimentos adequados de manuseio. As peças de madeira tratada demandam cuidados especiais para operações de serramento e furação e os resíduos dessas operações devem ser descartados corretamente. 
A orientação para os riscos à saúde dos trabalhadores deve, nesse sentido, ser responsabilidade também da usina de preservação e do fabricante dos produtos preservativos. Entretanto, ações de responsabilização como essas requerem um aparato de fiscalização, além da conscientização para serem adequadamente encaminhados.

Os altos custos do processo de tratamento preservativo também demandam a busca de alternativas de menor custo para possibilitar o atendimento à produção de habitação social.

Elo 9: operação de tratamento e uso - nesse elo, a participação do usuário é determinante para o aumento da sustentabilidade. Essa relação, para não resultar na diminuição da sustentabilidade requer a realização do tratamento de forma tecnicamente adequada e a utilização de procedimentos especiais por parte do usuário, significando um elo de risco.

Tendo sido ou não realizado o tratamento preservativo nos componentes de madeira, é importante que o usuário seja capacitado para a compreensão e reconhecimento do processo de deterioração, assim como para os cuidados com a madeira tratada com produtos tóxicos. A capacitação é um facilitador da correta execução de manutenções e destinação de produtos contaminados.

Seguindo o mesmo princípio do aumento da responsabilidade do fabricante pelos seus produtos, seria papel das empresas a orientação e alerta dos usuários para os riscos da utilização de produtos tóxicos para a saúde e meio ambiente. A sustentabilidade é aumentada com a participação do usuário na demanda por produtos mais amigáveis.

Com a utilização de produtos menos tóxicos no tratamento, é exigido do usuário o monitoramento da eficiência do tratamento, de acordo com a meia vida do produto utilizado. Considera-se nesse elo que o tipo de tratamento possa ser definido também de acordo com as aptidões do usuário (para conservação da habitação, manutenções e monitoramento).

Elo 10: operação de tratamento preservativo e processo de desconstrução - a responsabilidade pelo tratamento preservativo se estende até o fim da vida útil da habitação, quando a maior parte da madeira tratada é descartada e deve ser adequadamente descontaminada ou aproveitada. 
Como já analisado, a madeira, quando contaminada com CCA, requer cuidados especiais para o descarte. A queima deve ter temperatura controlada e cinzas adequadamente dispostas. Uma vez que formas de aproveitamento que envolvem a sua decomposição (composto, cobertura de jardim, por exemplo) não podem ser efetuadas pela degradação retardada e a deposição em aterros não é para nenhum material a melhor opção, é imprescindível a busca de alternativas de uso.

Num contexto de pouca informação sobre os potenciais riscos à saúde, deve se considerar a dificuldade de acesso a esse tipo de informação pelos usuários e empresas de demolição e também a possibilidade de investimento em programas de capacitação dos usuários para a correta destinação dos resíduos de reforma e desmontagem.

Elo 11: operação de usinagem e processo de projeto - como as perdas significativas de madeira ainda são a realidade das serrarias que trabalham com as espécies de florestas plantadas, maneiras inovadoras são requeridas para lidar com esse cenário, buscando sua sustentabilidade.

O aproveitamento de resíduos e subprodutos do processamento é um dos princípios da construção sustentável que pode ser influenciado pelo processo de projeto, através da criação de mercado e a demanda pela produção de materiais com algum conteúdo de material reaproveitado.

O Projeto de Políticas Públicas definiu ações para reforçar esse elo na cadeia produtiva da madeira de Itararé (e posteriormente de Itapeva). A relação se deu através da incorporação de resíduos do desdobro e usinagem das serrarias locais no rol de materiais passíveis de utilização na produção de habitação, na elaboração de produtos de desenho e técnica inovadores e do incentivo à criação de empreendimentos coletivos autogestionários, explorando a oportunidade de produção de componentes para habitação (esquadrias, peças) e artesanato. Essas ações visavam contemplar ao mesmo tempo as dimensões ambiental, econômica, social e política da sustentabilidade.

O aspecto econômico apresentava-se como fator crítico para a sustentabilidade, diante do encarecimento progressivo da matéria-prima e do cenário de crise do setor madeireiro formado pelos pequenos empreendimentos. Nesse ponto, o apoio à criação dos empreendimentos coletivos autogestionários teve o propósito de contribuir para a redução das desigualdades sociais, o empobrecimento e desemprego, sendo ressaltado em todos os 
elos sobre os quais o Projeto atuou. A tendência, dessa forma é o incentivo ao desenvolvimento de técnicas que utilizem mais mão-de-obra e menos processos automatizados.

Além da criação e reforço de cooperação entre projetistas e fabricantes, a inovação da proposta, demandou a capacitação de projetistas, para o qual foi elaborado um curso para projeto de habitação em madeira, oferecido a todos os projetistas (autônomos ou vinculados aos órgãos de governo) e estendido a marceneiros.

Para aumentar a sustentabilidade política, essas e outras ações foram definidas e conduzidas pelo Grupo Gestor formado por diferentes membros da comunidade. A diversidade era o aspecto-chave para reforçar os elos da cadeia produtiva.

Elo 12: processo de projeto e processo de construção - essa relação aumenta a sustentabilidade da cadeia produtiva através da definição de técnicas de construção que resultam em menor produção de resíduos, menor desgaste dos trabalhadores, que contemplem a capacitação de mão-de-obra e dos próprios usuários das habitações, assim como o resgate e utilização de técnicas que valorizem a cultura de construção local.

A introdução da pré-fabricação de componentes e a modulação são estratégias definidas em projeto que determinam não só o grau de impacto ambiental das edificações em madeira durante o processo de construção, mas também aspectos econômicos, sociais e até mesmo culturais.

Nesse aspecto, o processo de construção de edificações em madeira pode ser diversificado, das artesanais às mais industrializadas, sendo portanto mais flexível e adaptável a vários contextos de produção. A padronização de componentes num elevado grau de préfabricação, a exemplo do que ocorre nos países europeus, limita a personalização e diversidade dos projetos das habitações, mas por outro reduz o custo para os usuários.

A análise acurada do contexto e as previsões de cenários mais prováveis podem evitar insucessos na produção de habitação em madeira, como por exemplo a inadequada previsão de reposição de componentes que dependem de pré-fabricação em ambientes de baixa governabilidade.

No contexto da produção de habitação social, essas alternativas contestam e desafiam a situação atual da reduzida função e responsabilidade dos técnicos em detrimento da influência política (Agopyan, 2000). Tal desequilíbrio é, segundo o autor, a causa da grande 
incidência de patologias das construções, como conseqüência de deficiência de projeto, execução ou de materiais.

Os mecanismos para a produção de habitação social em larga escala demandam uma cuidadosa abordagem para que em nome de uma produção emergencial, não sejam produzidas habitações de baixa qualidade, ou embriões habitacionais que terão um crescimento degradado. $\mathrm{O}$ atendimento aos princípios sociais requer mais do que atender a recomendações isoladas, compreender o processo gerador, para elaborar alternativas que considerem o conjunto de questões envolvidas.

Mas a complexidade desses cenários por vezes atrasa ou cria impedimentos às inovações nos programas. As ações do Projeto de Políticas Públicas foram iniciadas no Município de Itararé, englobando a produção de habitação social paralelamente ao apoio ao desenvolvimento da cadeia produtiva da madeira da região.

Mas, ao longo do seu desenvolvimento, a participação e apoio do poder público diminuíram. Shimbo, L (2003) levanta as hipóteses de que "não houve um compartilhamento de um projeto político participativo e democratizante entre Grupo Gestor e poder público municipal” e "a ênfase dada à estratégia de capacitação técnicogerencial dos membros do Grupo Gestor em detrimento do seu fortalecimento enquanto sujeito político".

Silva e Shimbo (2004) discutem a dimensão política da formulação de políticas públicas para habitação na escala local e constatam que mesmo com as ações reforçadoras desenvolvidas com a comunidade através do Projeto, "prevalecem [...] práticas como clientelismo, assistencialismo e autoritarismo - configurando um cenário pouco participativo, onde os diferentes atores sociais atuam segundo seus próprios interesses".

Elo 13: processo de projeto e uso - o aspecto de maior discussão nesse elo é a sustentabilidade cultural das habitações em madeira. A justificativa para lidar com essa questão é a valorização de tecnologias de construção locais tradicionais, para a criação de uma identidade construtiva.

Tem um alto grau de importância pelos indícios da existência de preconceito em relação à habitação em madeira, possivelmente pelo símbolo negativo que os materiais nativos têm para os usuários, principalmente quando utilizados no atendimento a interesses sociais (CIB e UNEP-IETC, 2002). 
Fato observado na pesquisa de Shimbo, L (2003) no contexto atual do Projeto de Políticas Públicas, que está sendo desenvolvido no Assentamento Fazenda Pirituba, em Itapeva foi a preferência dos moradores do local pela alvenaria como principal material de construção das casas.

Nesse local, o trabalho de Shimbo, L. (2003) trata do desenvolvimento do projeto arquitetônico da unidade habitacional dos moradores do assentamento através do diálogo com os próprios futuros usuários. $\mathrm{Na}$ pesquisa-ação, são discutidos o processo de articulação, a elaboração de projeto e construção de habitação envolvendo não só os moradores com os pesquisadores, mas também os agentes da cadeia de produção da habitação.

Apesar de ter havido uma tentativa de discussão sobre as vantagens e desvantagens de cada material/ sistema construtivo, a madeira não foi facilmente aceita, tendo sido descrita nas reuniões apenas como "construção diferente", sobre a qual cerca de 50\% dos participantes se mostrou interessada, mediante a construção de uma casa-piloto para verificar a viabilidade técnico-construtiva, o conforto, a durabilidade e o custo da habitação. Essa estratégia é considerada pela construção sustentável na busca da recuperação da confiança dos usuários.

Para vencer o preconceito e rejeição do usuário, a participação do usuário nas definições de projeto é uma etapa importante a ser cada vez mais incorporada na produção de habitação em madeira. A pesquisa vislumbra a sensibilização e o aprendizado dos moradores na elaboração de estratégias para a solução dos problemas, através da realização de reuniões freqüentes, a composição de uma Coordenação Geral (formada por representantes dos moradores, pesquisadores, ITESP ${ }^{68}$ e outras lideranças com papéis definidos) e a participação democrática de todos os envolvidos. Correspondendo à observação de Dallari, todo o trabalho foi conduzido de maneira que os pesquisadores não assumissem posição de liderança no grupo.

O usuário capacitado para demandar sustentabilidade pode influenciar outros usuários e com isso criar o mercado para a construção sustentável e compreendendo o seu papel na cadeia produtiva, organizar-se na formação de grupos de consumidores para influenciar o desenvolvimento de produtos e serviços. A motivação da população para o planejamento -

${ }^{68}$ ITESP - Instituto de Terras do Estado de São Paulo 
elaboração e gerenciamento de projetos habitacionais - também favorece a sustentabilidade política.

Através da valorização da habitação em madeira, outras conseqüências positivas são geradas, como o aumento da vida útil, da qualidade e conforto. Outras questões que contribuem para aumentar a sustentabilidade nesse elo são:

- a otimização da técnica tradicional com a pré-fabricação de componentes para conjugar os pontos positivos;

- consideração das aptidões do usuário para reformas e ampliações;

- prever a ampliação, ser flexível e adaptável;

- inovar o design visando a maior utilidade.

A capacitação do usuário, através da participação no projeto, compreendendo as razões para as definições de projeto é um reforço para que em futuras reformas ou ampliações da habitação, as mesmas diretrizes de projeto e detalhamento sejam respeitadas.

Elo 14: processo de projeto e processo de desconstrução - a "aptidão para desmontagem", proposta pelo CIB, é definida ainda durante a fase de projeto. Para essa aptidão ainda deve ser considerado toda a vida útil da habitação e as manutenções que sofrerá até a sua desmontagem.

Por isso, a importância da capacitação do usuário para a melhor forma de utilização, assim como do adequado desenho para permitir o máximo reaproveitamento das peças de madeira para outros usos.

A demanda por produtos com conteúdo de material reaproveitado tende também a valorizar os resíduos pós-consumo, contribuindo para consolidar a desmontagem da habitação como um serviço imbuído da consciência para a sustentabilidade ambiental.

Elo 15: processo de construção e uso - a questão da identidade com a habitação em madeira também pode ser trabalhada no processo de construção da habitação em madeira. Estabelecer uma ligação maior entre a construção e o uso representa, de acordo com os princípios da construção sustentável apresentados, uma possibilidade de aumentar a 
capacidade do usuário para a adequada operação da habitação, aumentando conseqüentemente a sua qualidade e durabilidade.

Mesmo sem que haja participação direta do usuário, a construção sustentável demanda a informação do usuário através de sistemas on line, cartilhas e manuais do consumidor, sobre as qualidades ambientais e detalhes sobre as condições de uso e reciclagem.

A associação de consumidores para a compra de materiais de construção aumenta o poder de barganha e detém maior poder para demandar sustentabilidade e para combater os acréscimos nos preços de produtos certificados, como no caso da madeira (Vlosky \& Ozanne apud KIEKENS, 2000).

As vantagens da construção em madeira, como a agilidade, redução de desperdícios e custos de mão-de-obra são fatores que podem ser mais explorados para favorecer a aceitação do usuário.

Elo 16: processo de construção e processo de desconstrução - a introdução da visão de ciclo de vida nessa cadeia produtiva mostra a importância de trabalhar a desmontagem como mais uma etapa intermediária.

Nesse elo, a sustentabilidade ambiental é favorecida com a construção prevendo desmontagem, de maneira a reaproveitar o máximo dos materiais, implicando na utilização de menos recursos para a fabricação de materiais. Por isso, a montagem executada de acordo com o determinado no projeto executivo é fundamental para garantir o sucesso da desmontagem. A utilização da rotulação ambiental, informando a composição e outros dados do produto também pode auxiliar o procedimento.

Elo 17: uso e processo de desconstrução - um processo de desmontagem bem sucedido resulta na produção mínima de resíduos que são destinados à deposição em aterros. Qualquer outro destino - reuso, reaproveitamento ou reciclagem é considerado benéfico à sustentabilidade.

A conscientização do usuário sobre seu papel para a sustentabilidade determina em boa parte as condições para a desmontagem da habitação em madeira. As práticas de uso e manutenção determinam a presença de mais contaminantes na madeira (como tintas e vernizes). 
Analisando o conjunto dos elos da cadeia produtiva da habitação em madeira de plantios florestais apresentado, denotam-se os seguintes aspectos:

- os elos do final da cadeia produtiva têm uma análise de ganhos e perdas de sustentabilidade menos favorecida pela ausência de dados disponíveis;

- as relações para aumentar a sustentabilidade, apesar de serem numerosas, não são em sua maioria concretizadas;

- os elos atualmente são de relações que diminuem cada vez mais a sustentabilidade da cadeia produtiva da habitação em madeira de plantios florestais;

- existem elos que determinam repercussões em outros elos, representando pontos críticos a serem trabalhados enfaticamente nas estratégias para aumento da sustentabilidade. São: a desorganização dos agentes na formação de um único setor, aumento da concentração fundiária com aumento do controle dos preços das toras e dos produtos de madeira, o aumento das disparidades entre pequenos e grandes empreendimentos com redução gradativa da participação de pequenas empresas e pequenos agricultores.

- dos elos apresentados, os que lidam com duas ou mais dimensões são escassos e muitas vezes são apenas citados na literatura, sem serem desenvolvidos, diferentemente dos elos ambientais, com alto grau de definição, suficientes para estabelecer ações de cunho tecnológico. Esse desequilíbrio também contribui para aumentar a dificuldade de estabelecer a visão de cadeia produtiva.

Assim é obtida uma maior aproximação da dinâmica da cadeia produtiva da habitação, que embora limitada pela regionalização, permite uma abordagem sobre as melhores e piores associações para a sustentabilidade.

Com base nessas verificações, pode-se se dizer que a tendência geral da cadeia produtiva é, se mantiver os mesmos padrões de desenvolvimento dos elos relatados, a diminuição da sustentabilidade.

Por outro lado, nessa mesma cadeia produtiva são identificáveis elementos favoráveis à sustentabilidade que podem ser colocados em prática em curto prazo, para buscar a redução das diferenças. São: a criação de empreendimentos em torno da madeira de 
plantios florestais, a oportunidade de conjugar o desenvolvimento da cadeia produtiva com outras cadeias e de incluir populações excluídas em processos mais participativos.

É evidenciado também que a elucidação desses e outros elos depende da evolução do conhecimento sobre a cadeia produtiva e do próprio desenvolvimento da sua dinâmica. Alguns desses elos podem tornar-se enfraquecidos, até mesmo deixarem de existir, enquanto outros novos podem surgir. Isso significa que, apesar de nessa apresentação, elos considerados efêmeros terem sido suprimidos pela busca de uma abordagem que pudesse se adequar a vários contextos diferentes, cada contexto particularizado terá o seu conjunto de elos, e dentre eles, os que podem ser considerados vetores para estimular o desenvolvimento mais sustentável. 


\section{CONGLUSÕES}

A primeira verificação que se faz nessa pesquisa é de que o debate da sustentabilidade em sua forma mais abrangente, entendendo-se a incorporação das características de pluralidade e indissociabilidade, não estão inseridas nas discussões da construção sustentável.

A compreensão, ou pelo menos sua operacionalização, ainda é parcial, visível nos vários métodos de avaliação de sustentabilidade propostos. A investigação do entendimento do conceito indica uma excessiva simplificação em prol de julgamentos agilizados, onde ainda são preponderantes as questões ambientais. O resgate das características basais do conceito mostra quão imperativo é lidar com a complexidade para vislumbrar rumos para a sustentabilidade.

Essa verificação expõe as dificuldades para efetuar tal forma de abordagem, sobre a qual se constatou a necessidade de estabelecer uma escala espacial e as interações uni e pluridimensionais das questões de sustentabilidade que ocorrem nesse universo.

Realizar uma abordagem macro mostrou-se ser a mais apropriada, já que sabidamente, na escala micro (no caso, dentro dos processos ou das operações de transformação dos materiais de construção), muitos dos elos não são percebidos. Entre outras escalas maiores e menores, a escolha da escala da cadeia produtiva revelou-se a mais adequada para englobar a amplitude das questões para a discussão de sustentabilidade.

Por seu caráter histórico, a sustentabilidade deve ser buscada nas relações que se estabelecem em cada contexto, sobre o qual a compreensão da dinâmica das interações entre as questões torna-se pré-requisito para abordar a sustentabilidade.

Diante dessas duas grandes constatações então se pôde alcançar o objetivo de abordar a sustentabilidade da cadeia produtiva, entendendo o processo que determina os ganhos e perdas de sustentabilidade, através da apresentação dos elos entre os processos da cadeia produtiva, que abordam as estratégias em vigor e as novas propostas, para a análise das tendências à sustentabilidade. 
Com a apresentação da cadeia produtiva da habitação em madeira de plantios florestais, no Capítulo 1, verificou-se a falta de visão pluridimensional nos estudos sobre a cadeia produtiva, onde majoritariamente as preocupações ecológico-ambientais são suscitadas para fazer a relação com o conceito de sustentabilidade.

A complexidade dinâmica da cadeia produtiva ficou evidenciada pela repetição das variáveis em várias questões de dimensões diferentes, seja no envolvimento da sociedade local e regional, na interação com outras cadeias produtivas, na representatividade cultural, nas questões envolvendo os recursos físicos, econômicos e humanos.

São tantas as variáveis que determinam a sustentabilidade (observando o conceito e seus princípios) com relações tão intrincadas e que se modificam continuamente, que se percebe que a análise baseada somente nos princípios da dimensão ambiental não reflete a sua complexidade, pois basicamente estabelece comparações entre características inerentes aos materiais ou produtos.

O equilíbrio da análise de sustentabilidade de materiais de construção não é dado por aspectos quantitativos ou mensuráveis, mas pela igualdade de valor entre as várias questões que fazem parte dessa discussão. A busca de uma visão que contemple uma abordagem mais próxima do conceito foi a principal motivação para o desenvolvimento da pesquisa.

A análise da literatura acerca dos princípios do conceito de sustentabilidade aplicados ao setor da construção civil, tema do Capítulo 2, mostra a evolução, ainda que não sistematizada, de questões de outras dimensões da sustentabilidade, sobre as quais verificou-se a múltiplas possibilidades de contribuição da cadeia produtiva analisada.

Apesar do discurso contrário, a literatura apresentada nos Capítulos 2 e 3 ainda aborda a dimensão ambiental como a mais importante e os princípios das dimensões menos trabalhadas são menos detalhados, causando a percepção de que são ainda vagos.

Possivelmente pela introdução relativamente recente, muito pouco foi incorporado pelas pesquisas da construção civil e principalmente pela prática. Também com essa análise, evidenciou-se o quão limitados e simplificados são as abordagens realizadas nos países desenvolvidos. Com base nisso, a citação freqüente de que países desenvolvidos não requerem lidar com as questões sociais pode ser contestada, já que a busca da sustentabilidade, em todas as dimensões, é um movimento global. 
Essa forma de visão parcial configurou-se como um obstáculo ao desenvolvimento da presente pesquisa, uma vez a confiabilidade de muitos trabalhos é arriscada pela utilização de um mesmo termo de duas ou até três formas diferentes. Também dificultou a realização da pesquisa a forma compartimentada de desenvolvimento dos trabalhos, reflexo da forma de produção do conhecimento de um modo geral.

Dada a simplificação, não se identifica a abordagem da complexidade da realidade na maior parte dos métodos de avaliação de sustentabilidade, analisados no Capítulo 3. É comum a proposição de avaliações através de uma classificação das questões mais importantes ou mais urgentes para determinar as "melhores" ou "piores" edificações e materiais, que deixam o usuário à parte dos processos intermediários da avaliação. Faltam processos mais transparentes além de métodos que posicionam o usuário em cada passo do processo de tomada de decisões. A hierarquização nesse ponto, é a ferramenta utilizada para prover maior transparência, mas que em sua essência contraria a visão holística da sustentabilidade.

Neste trabalho, verificou-se que todas as questões são importantes igualmente não havendo possibilidade de hierarquização de questões mais ou menos urgentes, já que todos têm a sua parcela de contribuição na definição da questão. Do mesmo modo, conclui-se que a resposta à questão sobre a sustentabilidade da madeira de plantios florestais para habitação depende do processo de perdas e ganhos de sustentabilidade, analisados ao longo da cadeia produtiva. A resposta é sempre relativa, visto que o processo é contínuo, tanto numa única dimensão quanto na relação entre dimensões. A estrutura analisada é muito dinâmica para permitir a elaboração uma análise estática.

Em virtude disso, considera-se que ao invés de buscar respostas simplificadas (que remetem a análises igualmente simplificadas) com foco no material, seja mais adequada a busca de contextos melhores de sua produção. Do mesmo modo, fica evidenciado que cenários totalmente sustentáveis são intangíveis, devendo a busca ser baseada na construção de cenários cada vez mais sustentáveis, com apoio à uma referência anterior.

Com o propósito de lidar com a complexidade, a análise de referenciais conceituais e dos próprios métodos de avaliação de sustentabilidade indicou a falta de uma compreensão da dinâmica dos processos. Por isso a investigação sobre a cadeia produtiva buscou compreender o processo de ganhos e perdas de sustentabilidade, através de suas múltiplas dimensões, assunto do Capítulo 4. A opção foi estabelecer elos entre processos, cujas relações podem ser de favorecimento mútuo ou com potencial de conflito. 
O trabalho foi esquadrinhado para não se ater a elos fracos - temporários ou sazonais, estabelecendo os elos mais fortes, que invariavelmente existirão em qualquer cadeia produtiva da habitação em madeira de plantios florestais.

Como uma forma de trabalhar a complexidade do conceito de sustentabilidade de forma pragmática e para suprir a lacuna de informações sobre a cadeia produtiva para embasamento do estudo, dados coletados em revisão bibliográfica e em visitas à região sudoeste do Estado de São Paulo foram integrados.

Essa forma de aproximação se mostrou positiva por proporcionar um estudo mais definido e para ratificar o quão particular de um lugar é esse tipo de análise. Embora tenha se tentado buscar um conjunto de elos que representassem um contexto que se aplique a vários lugares, explorando as questões que são tratadas comumente na literatura, as ações e estratégias nesses elos são referentes a um contexto específico.

Isso ocorre porque em cada elo existem muitas variáveis envolvidas e em cada contexto essas variáveis são trabalhadas de formas diferentes. Por isso, a adequação de um material em relação aos princípios de sustentabilidade é dada pela análise conjunta do maior número possível de variáveis em um determinado contexto, podendo ser aplicável, mas não replicável em outros. A sustentabilidade é inerente ao lugar porque as relações de ganhos e perdas não são comparáveis entre si, não só porque os dados utilizados sejam específicos de um lugar, mas também porque a percepção de "ganho" ou de "perda" pode ser interpretada de diferentes formas em outros contextos.

Analisando os resultados, observa-se que as oportunidades para a sustentabilidade da cadeia produtiva são mais significativas nos elos do que dentro dos processos, o que denota a menor representatividade da tecnologia nesse papel.

As maiores oportunidades no contexto atual estão no aproveitamento das condições atuais - considerando as características de baixa produtividade e qualidade - para a organização do setor, visando a elaboração de novos produtos e a geração de empregos e renda com foco nos pequenos produtores, da produção florestal à produção dos componentes para habitação. É, declaradamente, a potencialização de pequenos empreendimentos como alternativa ao desenvolvimento das grandes empresas, numa estratégia de diversificação.

A compartimentação dos estudos sobre a cadeia produtiva contribui para a percepção de que os aspectos negativos à sustentabilidade são maiores do que os positivos. A visão a partir dos elos da cadeia produtiva, nesse sentido, valoriza as oportunidades existentes. 
Os elos da cadeia produtiva ainda necessitam ser mais trabalhados para englobar a discussão da sustentabilidade, ultrapassando as questões de cunho técnico tradicionalmente abordadas.

Entende-se que qualquer trabalho de desenvolvimento de estratégias mais robustas ou de caminhos para fortalecer o processo de tomada de decisões para a real sustentabilidade dessa cadeia produtiva precisa antes ter disponível o conhecimento sobre a dinâmica sobre a qual vai atuar, numa ótica pluridimensional.

Se o conceito de sustentabilidade e a cadeia produtiva são assuntos que por si só demandam a realização de várias outras pesquisas, a elaboração deste trabalho que as integram configurou-se como uma parte, num escopo maior de futuras pesquisas sobre o mesmo assunto.

Espera-se que este estudo tenha sido uma contribuição na construção de informações que subsidiem futuras pesquisas de avaliação integrada de sustentabilidade da cadeia produtiva, na formulação de indicadores, além de apoiar a operacionalização do conceito de sustentabilidade e de seus princípios.

$\mathrm{Na}$ pesquisa da sustentabilidade de materiais de construção em geral, espera-se que a contribuição seja no sentido de mostrar como a complexidade do contexto em que se insere o objeto analisado interfere na sua sustentabilidade, a gama de interações que se estabelece numa análise de sustentabilidade e a possibilidade de estabelecer estudos similares, com a mesma abordagem.

Para a pesquisa de métodos de avaliação de sustentabilidade, é esperada que a contribuição tenha sido dada na necessidade de uma real abordagem pluridimensional, de viabilização de maior transparência no processo de tomada de decisões e na explicitação do funcionamento do sistema. Para que este trabalho também venha a se configurar como um método, é necessário buscar meios mais amigáveis de interação com o usuário e adequação aos diferentes tipos de usuários do método.

Estudos semelhantes para a cadeia produtiva de espécies nativas também são demandados, principalmente visando substituir o uso de espécies exóticas nos plantios florestais. Fator que justificaria a execução desses estudos é a variedade de espécies nativas que poderiam atender às demandas do setor.

A elaboração de mais estudos com o mesmo enfoque de sustentabilidade poderá contribuir para o embasamento e definição de políticas de impacto no setor e que efetivamente 
contribuam para delinear um horizonte mais sustentável da cadeia produtiva da habitação em madeira de plantios florestais. 


\section{REFERÊNCIAS BIBLIOGRÁFICAS}

AB'SÁBER, A. (org) (1990) Projeto FLORAM - uma plataforma. Revista Estudos Avançados. IEA/ USP: São Paulo. Maio/ agosto. Vol.4. Número 9.

ABIMCI (2004a) Estudo setorial 2003 - Produtos de madeira sólida. Disponível em: <http://www.abimci.com.br/port/03Dados/0306EstSet2003/03060602Serrados.html> Acesso em: 02 maio.

ABIMCI (2004b) Estudo setorial 2003 - Produtos de madeira sólida. Disponível em: <http://www.abimci.com.br/port/03Dados/0306EstSet2003/03060603PMVA.html> Acesso em: 02 maio.

AGOPYAN, V. (2000) Habitação de interesse social e a tecnologia - Projeto TECHOS. In: El habitat iberoamericano en la mira. Antigua: Cyted. [Subprograma XIV Tecnología para viviendas de interés social] p.161-167. [CD].

ANINK, D.; BOONSTRA, C.; MAK, J. (1996) Handbook of sustainable building : an environmental preference method for selection of materials for use in construction and refurbishment. Londres: James \& James. 175 p.

ARAKAKI, E. M. (2000) Avaliação de durabilidade em sistema construtivo préfabricado com madeira de rejeito comercial. Estudo de caso: Conjunto Habitacional Pedra 90. São Carlos: EESC/ USP. Dissertação de Mestrado. Programa de pós-graduação em Tecnologia do Ambiente Construído. 260p.

ARRUDA, M. P.; INO, A. (2000) Avaliação do grau de sustentabilidade ambiental das edificações: método utilizado na Holanda e Bélgica. In: ENCONTRO NACIONAL DE TECNOLOGIA DO AMBIENTE CONSTRUÍDO, 8. Salvador. Anais...Salvador, UFBA. [CD].

ARRUDA, M. P.; INO, A. (2002) Diretrizes para projeto arquitetônico de habitação social produzida por mutirão. In: ENCONTRO NACIONAL DE TECNOLOGIA DO AMBIENTE CONSTRUÍDO, 9. Foz do Iguaçu. Anais...Foz do Iguaçu, ANTAC. [CD]. 
ASSEFA, G. (2002) Comparison of four life cycle based environmental assessment tools of buildings, real estates and infrastructures. In: SUSTAINABLE BUILDING, 3. Oslo.

Proceedings... Oslo, Ecobuild. [CD].

BAKENS, W. (2003) Realizing the sector's potential for contributing to sustainable development. Industry and environment, Paris, v.26, n. 2-3, p.9-12, abr-set.

BARBOSA, J. C.; INO, A.; SHIMBO, I. (2000) Indicadores de sustentabilidade na cadeia produtiva de habitação em madeira de reflorestamento. In: ENCONTRO NACIONAL DE TECNOLOGIA DO AMBIENTE CONSTRUÍDO, 8. Salvador. Anais...Salvador, UFBA. [CD].

BARBOSA, J. C.; INO, A.; SOUZA, A. J. D. (2003) Consumo de energia na produção de painéis de vedação em habitação de interesse social em madeira. In: ENCONTRO NACIONAL SOBRE EDIFICAÇÕES E COMUNIDADES SUSTENTÁVEIS, 3. Anais.... São Carlos: USP/ UFSCar/ UNESP.

BARRICHELO, L.G.E (1990) O FLORAM em discussão. In: AB’SÁBER, A. (org) Projeto FLORAM - uma plataforma. Revista Estudos Avançados. IEA/ USP: São Paulo. maio/ ago. Vol.4. Número 9.

BATALHA, M. O. (1997) Sistemas Agroindustriais: definições e correntes metodológicas. In: BATALHA, M. O. (Coord.) Gestão Agroindustrial. São Paulo: Atlas. v.1, p.23-48.

BAYNE, K. M. B. et al. (2002) From the shopfront to the street - the future for wooden buildings in a sustainable world In: Sustainable Building, 3. Proceedings...Oslo: Ecobuild. [CD]

BEQUEST (2004) Life in County Durham - more or less sustainable? For better or worse -25 ways of measuring changes to your environment. Durham: Government Office for the North East and Environment Agency. 10p.

BERTALANFFY, L. V. (1977) Teoria geral dos sistemas.Petrópolis: Vozes. $3^{a}$ edição. Coleção Teoria dos Sistemas/ 2. Francisco M. Guimarães (trad.).

BLACK, L.J.; CARLILE, P.R.; REPENNING, N.P. (2000) Improving the practice of process improvement. Cambridge: MIT. Disponível em: < http://web.mit.edu/nelsonr> Acesso em: 10 mar. 2002.

BRASIL. MINISTÉRIO DA CIÊNCIA E TECNOLOGIA (2000) Necessidades de ações de desenvolvimento tecnológico na produção da construção civil e da construção habitacional: documento Fórum Construção: versão final. Coordenação de Léo Frederico Cinelli e Maria Lucia Horta de Almeida. Brasília: MCT. 21p. 
BREEAM (2004) BREEAM. Disponível em:

$<$ http://www.bre.co.uk/services/BREEAM_and_EcoHomes.html> Acesso em: 10 fev.

BULHÕES, F.M; SOUZA, R. S. (2002) Certificação florestal: perfil, similaridades e divergências entre os modelos existentes. In: ENCONTRO BRASILEIRO EM MADEIRA E EM ESTRUTURAS DE MADEIRA, 8. Uberlândia. Anais...Uberlândia, UFU. [CD].

BUNN, R. (2003) Sustainable building services in developing countries: the challenge to find "best-fit" technologies. Industry and environment, Paris, v.26, n. 2-3, p.46-52, abrset.

CAMPBELL, G. S.; HARTLEY, J. (1978) Drying and dried wood. In: Eucalypts for wood production. HILLIS, W. E; BROWN, A. G. Austrália: CSIRO. p. 328-336.

CAMPOS, C. I. e LAHR, F. A. R. (2003) Propriedades físico-mecânicas de MDF fabricado a partir de resíduos de espécies de reflorestamento e adesivo alternativo. In: ENCONTRO NACIONAL SOBRE EDIFICAÇÕES E COMUNIDADES SUSTENTÁVEIS, 3. Anais.... São Carlos: USP/UFSCar/UNESP.

CANADIAN WOOD COUNCIL (1996) Fire Safety Design in Buildings. Ottawa: Canadian Wood Council. 358p.

CARLOS, V. J. (1995) Resistência a insetos xilófagos. Revista Téchne, São Paulo, n.19, p.42-43, nov./dez.

CARMO, R. L. e HOGAN, D, J. (1995) O desenvolvimento humano 1995: informe sobre desarollo humano - Programa das Nações Unidas para o Desenvolvimento. In: Revista Brasileira de Estudos de População. V. 12 n. 1-2, jan/dez. Disponível em:

<http://www.abep.org.br/ docs/rev_inf/r12/r1.htm> Acesso em: 10 jan. 2003.

CASBEE (2004) CASBEE. Disponível em:

<http://www.ibec.or.jp/CASBEE/CASBEE_Ever1/index.htm> Acesso em: 07 set. 2004.

CÉSAR, S. F. (2003) Aproveitamento de segmentos de tábuas da madeira de eucalipto para produção de componentes reconstituídos. In: ENCONTRO NACIONAL SOBRE EDIFICAÇÕES E COMUNIDADES SUSTENTÁVEIS, 3. Anais.... São Carlos: USP/UFSCar/UNESP.

CIB (1999) Agenda 21 on Sustainable Construction. Rotterdam: CIB. 120p. [CIB Report Publication 237]. 
CIB e UNEP-IETC. (2002) Agenda 21 for Sustainable Construction in Developing

Countries. Pretoria, África do Sul: CSIR Building and Construction Technology.

[Documento para discussão].

COLE, R. J.; LARSSON, N. (1998) Green building challenge '98 assessment manual. 4 v. V.1: Overview, V.4: Multi-unit residential buildings. Disponível em:

$<$ http://greenbuilding.ca/down/gbc98> Acesso em: 10 fev.

COOPER, P. A. (1993) Leaching of CCA: Is it a problem? In: ENVIRONMENTAL CONSIDERATIONS IN THE MANUFACTURE, USE, AND DISPOSAL OF

PRESERVATIVE-TREATED WOOD. Madison. Proceedings... Madison, USA: Forest Product Society. p.45-57

COYLE, R. G. (1996) System dynamics modeling: a practical approach. Londres: Chapman e Hall. 413p.

CURWELL, S. (1996) Specifying for greener buildings. The architects' journal. Janeiro. pg.38-40.

DALLARI, D. A. (1994) O que é participação política. São Paulo: Brasiliense. Coleção Primeiros passos. $13^{\mathrm{a}}$ ed. $100 \mathrm{p}$.

DEL MENEZZI, C. H. S. (1999) Utilização de um método combinado de desdobro e secagem para a produção de madeira serrada de Eucalyptus grandis Hill exMaiden e E. cloeziana F. Muell. Piracicaba. Dissertação (Mestrado em Ciências) Escola Superior de Agricultura "Luís de Queiroz", Universidade de São Paulo.

DESIDERÁ, C. e ZANIN, M. (2003) Avaliação de compostos de poliestireno de alto impacto reciclado e resíduos de serrarias. In: ENCONTRO NACIONAL SOBRE EDIFICAÇÕES E COMUNIDADES SUSTENTÁVEIS, 3. Anais.... São Carlos: USP/UFSCar/UNESP.

DUCATTI, M.A.; JANKOWSKY, I.P.; ANDRADE, A. (2001). Condições operacionais da secagem convencional em indústrias madeireiras no Município de Tietê/ SP. Scientia Forestalis. S.l., n. 59, p. 101-113, jun. Disponível em:

<http://www.ipef.br/publicacoes/scientia/nr59/cap08.pdf> Acesso em: 13 abr. 2004.

ECOEFFECT (2004) EcoEffect. Disponível em: <http://www.infra.kth.se/ecoeffect/> Acesso em: 07 set.

EDGAR, J. G. (1978) Social and environmental implications. In: Eucalypts for wood production. HILLIS, W. E; BROWN, A. G. Australia: CSIRO. p. 377-389. 
EDWARDS, S.; BENNETT, P. (2003) Construction products and life-cycle thinking. Industry and environment, Paris, v.26, n. 2-3, p.57-61, abr-set.

FAPESP - Fundação de Amparo à Pesquisa do Estado de São Paulo (2002) O setor florestal na era da genômica. Revista FAPESP. São Paulo: FAPESP. Disponível em: <http://www.revistapesquisa.fapesp.br> Acesso em: 21 mar. 2004.

FAPESP - Fundação de Amparo à Pesquisa do Estado de São Paulo (2004). A genética lucrativa do papel. Revista FAPESP. Disponível em:

<http://www.revistapesquisa.fapesp.br> Acesso em: 21 mar. São Paulo: FAPESP.

FARIA NETO, A.M; FARIA, A.M; MACÊDO, A.N. (2002) Projeto e execução de casa popular de painéis pré-fabricados de argamassa e madeira. In: ENCONTRO BRASILEIRO EM MADEIRA E EM ESTRUTURAS DE MADEIRA, 8. Uberlândia. Anais...Uberlândia, UFU. [CD].

FERGUSON, I. S.; DARGAVEL, J. B. (1978) Economic considerations. In: Eucalypts for wood production. HILLIS, W. E; BROWN, A. G. Australia: CSIRO. p. 364-374.

FERREIRA JUNIOR, P. C. (2003) Habitação social em madeira de reflorestamento como alternativa econômica para usos múltiplos da floresta. São Carlos: USP. [relatório de bolsa de treinamento].

FINGER, A., MEILI, M. (2002) Durability of non covered timber bridges. Zurique, Suíça: EMPA. 94p. Dissertação de mestrado.

FIORELLI, J.; DIAS, A. A. (2002) Avaliação de adesivos para uso no reforço de elementos estruturais de madeira com fibras. In: ENCONTRO BRASILEIRO EM MADEIRA E EM ESTRUTURAS DE MADEIRA, 8. Uberlândia. Anais...Uberlândia, UFU. [CD].

FOLHA DE SÃO PAULO (2003) Indicadores sociais do Estado de São Paulo. Jornal Folha de São Paulo. São Paulo: 19 set. 2003.

FSC (2000) Padrões de certificação do FSC para o manejo florestal em plantações florestais no Brasil: documento 7.0. [s.1.]: Grupo de Trabalho do FSC. 32p.

GALINARI, A. F.; INO, A. (2004) Indicação de variáveis de racionalização que influenciam a escolha de sistemas construtivos nos projetos de habitação social em madeira de plantios florestais. In: ENCONTRO NACIONAL DE TECNOLOGIA DO AMBIENTE CONSTRUÍDO, 10. São Paulo. Anais...São Paulo, ANTAC. [CD]. 
GALVÃO, A. P. M. (1976) Aspectos da utilização da madeira de eucalipto no Brasil; seu aproveitamento em serraria. Piracicaba: Instituto de Pesquisas e Estudos Florestais. v. 4. 23p. [circular interna].

GAVA, M.; ALBANO FILHO, P. (2004) Levantamento dos produtos das serrarias da Região Sudoeste do Estado de São Paulo. São Carlos: EESC/ USP. [não publicado].

GIBBERD, J. (2004) The sustainable building assessment tool: assessing how buildings can support sustainability in developing countries. Disponível em:

$<$ http://www.civils.org.za/bepc/jgibberd.pdf> Acesso em: 07 set.

GLAUMANN, M. et al. (2002) Environmental Indicators for the Building Sector. - User Questionnaires as a Basis for Indoor Indicators. In: Sustainable Building, 3.

Proceedings...Oslo: Ecobuild. [CD].

GLAUMANN, M.; ASSEFA, G.; KINDEMBE, B. (2002) A simplified weighting method for environmental impacts. In: SUSTAINABLE BUILDING, 3. Oslo. Proceedings... Oslo, Ecobuild. [CD].

GONÇALVES et al. (2001) Caracterização de resíduos e otimização de processos produtivos em indústrias madeireiras. Bauru, UNESP, 2001. Projeto PATME Tipo A SEBRAE/ FINEP. Disponível em:

$<$ http://www.unesp.br/propp/dir_proj/Industria/Industr27.htm> Acesso em: 24 abr. 2004.

GONÇALVES, M. T. (1992) Exploração florestal, desenvolvimento e sociedade. In: HENRI ACSELRAD (org). Meio Ambiente e Democracia. Rio de Janeiro: IBASE. p. $70-87$.

GONÇALVES, M. T. T. (2000) Processamento da madeira. Bauru: Marcos Tadeu Tibúrcio Gonçalves. 242 p.

GONÇALVES, M.T.T.; SOUZA, A.J.D; BARBOSA, J.C. (2002) Geração de resíduos em serrarias de pinus. In: ENCONTRO BRASILEIRO EM MADEIRA E EM

ESTRUTURAS DE MADEIRA, 8. Uberlândia. Anais...Uberlândia, UFU. [CD].

GREEN BUILDING DIGEST (1996) Timber preservatives. Liverpool: GBD. n.12, set.

GREEN BUILDING DIGEST (1995) GREEN BUILDING DIGEST. Liverpool: ACTAC. [freqüência irregular]. 
GREEN GLOBES (2004) Green globes. Disponível em:

$<$ http://www.greenglobes.com/design/about.asp> Acesso em: 8 set.

GREENO, J. L. (1994) Corporate environmental excellence and stewardship. In:

Environmental strategies handbook: a guide to effective policies and practices. Kolluru, R. (editor). New York: McGraw-Hill. p 43-64.

HÄKKINEN, T. (2001) City related sustainability indicators: state of the art. Finland: CRISP. Disponível em: < http://crisp.cstb.fr> Acesso em: 10 jan. 2003.

HENN, C. L; FAVA, J. A. (1994) Life cycle analysis and resource management. In: Environmental strategies handbook: a guide to effective policies and practices. Kolluru, R. (editor). New York: McGraw-Hill. p 541-641.

HILL, R.; BOWEN, P.; OPPERMAN, L. (2002) Sustainable building assessment methods in South Africa: an agenda for research. In: SUSTAINABLE BUILDING, 3. Oslo.

Proceedings... Oslo, Ecobuild. [CD].

HILLIS, W. E.; BROWN, A. G. (1978) The need for improved wood production from eucalypts. In: Eucalypts for wood production. HILLIS, W. E; BROWN, A. G. Australia: CSIRO. p. 393-402.

HIRSCHHORN, J. S. (1994) Business and the environment. In: Environmental strategies handbook: a guide to effective policies and practices. Kolluru, R. (editor). New York: McGraw-Hill. p 31-42.

HK-BEAM (2004) HK-BEAM (Residential): an environmental assessment for new residential buildings. Disponível em: < http://www.bse.polyu.edu.hk/Research_Centre/ BEP/hkbeam/acrobat/hk-beam_3-99.pdf> Acesso em: 07 set.

HUOVILA, P. et al (2001) Sustainability assessment of building design, construction and use. Disponível em:

<http://research.scpm.salford.ac.uk/resources/lisbon/papers\%5Cpekka.pdf> Acesso em: 07 set. 2004.

INO, A. et al. (2000) "Habitação de interesse social como alternativa econômica para usos múltiplos da floresta”. Relatório de pesquisa FAPESP - FASE I. São Carlos: EESC/USP - UFSCar. [Modalidade: Políticas Públicas - primeiro edital]

INO, A. et al. (2002) "Habitação de interesse social como alternativa econômica para usos múltiplos da floresta". Relatório de pesquisa FAPESP - FASE II parcial. São Carlos: EESC/USP - UFSCar. [Modalidade: Políticas Públicas - primeiro edital] 
INO, A. et al. (2004) "Habitação de interesse social como alternativa econômica para usos múltiplos da floresta". Relatório de pesquisa FAPESP - FASE II final. São Carlos: EESC/USP - UFSCar. [Modalidade: Políticas Públicas - primeiro edital]

INSTITUTO ETHOS (2004a) Indicadores Ethos aplicados aos princípios do Pacto Global. São Paulo: Instituto Ethos de Empresas e Responsabilidade Social. 48p.

INSTITUTO ETHOS (2004b) Indicadores Ethos de responsabilidade social empresarial. São Paulo: Instituto Ethos de Empresas e Responsabilidade Social. 68p.

INSTITUTO ETHOS (2004c) Indicadores Ethos setoriais - setor de construção civil. São Paulo: Instituto Ethos de Empresas e Responsabilidade Social. [material para consulta pública].

ISO (2004) ISO. Disponível em: <http://www.iso.org> Acesso em: 21 out.

IZIQUE, C. (2004) Bula do crescimento. Pesquisa FAPESP, São Paulo, n.102, p.82-87, ago.

JUMEZ, V. et al (2002) Multi-actor and multicriteria methodological approach integrating sustainable development in the decision of a social building provider. In: SUSTAINABLE BUILDING, 3. Proceedings...Oslo: Ecobuild. [CD].

KAATZ, E.; BARKER, G.; HILL, R.; BOWEN, P. (2002) A comparative evaluation of building environmental assessment methods: suitability for the South African context. In: SUSTAINABLE BUILDING, 3. Oslo. Proceedings... Oslo, Ecobuild. [CD].

KERRUISH, C. M. (1978) Harvesting. In: Eucalypts for wood production. HILLIS, W. E; BROWN, A. G. Australia: CSIRO. p. 229-255.

KIBERT, C. J. (2003) Deconstruction: the start of a sustainable materials strategy for the built environment. Industry and environment, Paris, v.26, n. 2-3, p.84-88, abr-set.

KIEKENS, J. P. (1999) Forest certification, part I: origins, background and recent trends. S.l.: Engineered wood journal. Disponível em: <http://www.apawood.org/news/journal.html> Acesso em: 10 jan. 2000.

KOHLER, N., MOFFATT, S. (2003) Life-cycle analysis of the built environment. Industry and environment, Paris, v.26, n. 2-3, p.17-21, abr-set.

KOLLURU, R. V. (1994) Environmental Strategies Handbook: a guide to effective policies and practices. Kolluru, R. (editor). New York: McGraw-Hill. 1030p. 
KRONKA, F. J. N. (org.) (2002) Inventário Florestal das áreas reflorestadas do Estado de São Paulo. Francisco J. N. Kronka et al. São Paulo: Secretaria de Estado do Meio Ambiente/ Instituto Florestal. 184 p.

LARSSON, N. (2004) GBC. Disponível em:

<http://greenbuilding.ca/iisbe/start/iisbe.htm> Acesso em: 01 ago. 2003.

LATORRACA, J.V.F. (2002) Estudo comparativo entre dois métodos utilizados na avaliação da aptidão da madeira para o uso em chapas de cimento-madeira. In: ENCONTRO BRASILEIRO EM MADEIRA E EM ESTRUTURAS DE MADEIRA, 8. Uberlândia. Anais...Uberlândia, UFU. [CD].

LEPAGE, E. S. (1986) Manual de preservação de madeiras. São Paulo: IPT.

LEPAGE, E. S. e CAVALCANTE, M. S. (1986) Aspectos ligados à higiene e segurança industrial e ao controle da poluição. In: LEPAGE, E. S. (coord.). Manual de preservação de madeiras. São Paulo: IPT. vol. 2. pg. 563-582.

LEROY, J. P. et al. (2002) Tudo ao mesmo tempo agora: desenvolvimento, sustentabilidade, democracia: o que isso tem a ver com você? Petrópolis: Vozes. 198p.

LIMA, W. P. (1993) Impacto ambiental do eucalipto. 2.ed. São Paulo: Editora da Universidade de São Paulo. 301p.

LINDENMAYER, D. B. (1995) Forest disturbance, forest wildlife conservation and the conservative basis for forest management in the mountain ash forests of Victoria.

Amsterdam: Elsevier Science. Disponível em: <

http://isi02.isiknowledge.com/portal.cgi?DestApp=WOS\&Func=Frame $>$ Acesso em: 01 nov. 2004.

LYLE, J. T. (1994) Regenerative design for sustainable development. Nova York: Wiley. 338p.

LOMBARDI, P. (2000) Analytic Hierarchy Process. Disponível em:

<http://research.scpm.salford.ac.uk/bqtoolkit/index2.htm> Acesso em: 07 set. 2004.

MAMBELLI, T. (2000) Social impact assessment. Disponível em:

<http://research.scpm.salford.ac.uk/bqtoolkit/index2.htm> Acesso em: 07 set. 2004.

MARCOVITCH, J. (1990) As origens do Projeto FLORAM. In: AB’SÁBER, A. (org) Projeto FLORAM - uma plataforma. Revista Estudos Avançados. IEA/ USP: São Paulo. maio/ agosto. Vol.4. Número 9. 
MARTÍNEZ, E. (coord.) (1998) Postulados de la red "viviendo y construyendo" de cara a la conferencia mundial sobre la ciudad HABITAT II. Programa de Ciencia y Tecnología para el Desarrollo. Red XIV.B. CYTED.

MARTINS, V. A. (1988) Secagem de madeira serrada. Brasília: IBDF/ DPq-LPF. 56 p.

MARTUCCI, R. (1990) Projeto tecnológico para edificações: utopia ou desafio? São Paulo. Tese de Doutorado, Faculdade de Arquitetura e Urbanismo, Universidade de São Paulo.

MCDONOUGH, N.; MOFFATT, S. (2003) Life-cycle analysis of the built environment. Industry and environment, Paris, v.26, n. 2-3, p.17-21, abr-set.

MIYADAIRA, L.Y.; BITTENCOURT, R.M. (2002) Proposta de um banco de dados informatizado para os sistemas construtivos em madeira. In: ENCONTRO BRASILEIRO EM MADEIRA E EM ESTRUTURAS DE MADEIRA, 8. Uberlândia.

Anais...Uberlândia, UFU. [CD].

MOREIRA et al. (2002) Projeto, fabricação e montagem da edificação formada por colunas de MLC e tesouras treliçadas de madeira de eucalipto. In: ENCONTRO BRASILEIRO EM MADEIRA E EM ESTRUTURAS DE MADEIRA, 8. Uberlândia. Anais...Uberlândia, UFU. [CD].

MULLINS, M. L. (1994) Industry perspective: environmental health and safety challenges and social responsibilities. In: Environmental strategies handbook: a guide to effective policies and practices. Kolluru, R. (editor). New York: McGraw-Hill. p 201-238.

MUNDA, G; NIJKAMP, P.; RIETVELD, P. (1994) Multicriteria evaluation in environmental management: why and how? In: Applying multiple criteria aid for decision to environmental management. Dordrecht: Kluwer Academic. Euro Courses. Environmental Management. v.3.

MURAKAMI et al (2002). Comprehensive assessment system of building environmental efficiency in Japan (CASBEE-J). In: SUSTAINABLE BUILDING, 3. Oslo. Proceedings... Oslo, Ecobuild. [CD].

NABERS (2004) National Australian built environment rating system (NABERS). Disponível em: <http://www.deh.gov.au/industry/construction/nabers/userspreadsheets.html> Acesso em: 07 set.

OLIVEIRA, M. C. G.; HEINECK, L. F. M. (1998) Habitabilidade - um estudo sobre os fatores que influenciam a satisfação de usuários de ambientes construídos. In: 
ENCONTRO NACIONAL DE TECNOLOGIA DO AMBIENTE CONSTRUÍDO, 7. Florianópolis. Anais....Florianópolis, UFSC. [CD].

OPIE, J. E.; CURTIN, R. A.; INCOLL, W. D. (1978) Stand management. In: Eucalypts for wood production. HILLIS, W. E; BROWN, A. G. Austrália: CSIRO. p. 179-225.

PAGE, M. W. (1978) Production of sawn wood from small eucalypt logs. In: Eucalypts for wood production. HILLIS, W. E; BROWN, A. G. Austrália: CSIRO. p. 322-327.

PARUCCINI, M. (Ed.) (1994) Applying multiple criteria aid for decision to environmental management. Dordrecht: Kluwer Academic. Euro Courses. Environmental Management. v.3.

PASEK, E.A. (1994) Air emissions from burning CCA-treated wood. In: Conference Wood preservation in the 90's and beyond. Savannah. Proceedings... Madison, WI, USA: Forest Product Society. p. 42-48.

PRAVIA, Z.M.C; GHELEN, J. (2002) Um sistema industrializado para moradia popular com estrutura e fechamentos em madeira. In: ENCONTRO BRASILEIRO EM MADEIRA E EM ESTRUTURAS DE MADEIRA, 8. Uberlândia. Anais...Uberlândia, UFU. [CD].

REDEFINING PROGRESS (2004) Redefining Progress. Disponível em: $<$ http://www.rprogress.org> Acesso em: 07 set.

RICHARDSON, B. A. (1978) Wood preservation. Lancaster: The Construction Press. 238p.

ROSSETO, A. M. et al (2004b) A utilização de um balanced scorecard para sustentação das estratégias de desenvolvimento sustentável de cidades. In: CONFERÊNCIA LATINO AMERICANA DE CONSTRUÇÕES SUSTENTÁVEIS, 1 e ENCONTRO NACIONAL SOBRE TECNOLOGIA DO AMBIENTE CONSTRUÍDO, 10. São Paulo. Anais... São Paulo, ANTAC. [CD].

ROVERS, R. (2003) The role of policies in promoting sustainable practices. Industry and environment, Paris, v.26, n. 2-3, p.29-32, abr-set.

SANTOS, G. R. V.; JANKOWSKY, I. P.; ANDRADE, A. (2003) Curva característica de secagem para madeira de Eucalyptus grandis. Scientia forestalis, s.l., 2003, n.63, p.214-220. Disponível em < http://www.ipef.br/publicações/scientia/nr63/cap18.pdf> Acesso em 24 abr. 2004. 
SEADE (2004) Fundação SEADE. Disponível em: < http://www.seade.gov.br/cgibin/lingcv98/tabela.htm> Acesso em 26 nov. 2003.

SEBRAE (1999) PRODER especial: um vetor de sustentabilidade econômica em processos de desenvolvimento local integrado e sustentável. FRANCO, A. (coord.). Brasília: SEBRAE.

SEBRAE/SP (2000) PRODER - Programa de emprego e renda: Itararé. São Paulo: SEBRAE. 16p. [não publicado]

SÃO PAULO (1990) Subsídios do Instituto Florestal para o Projeto FLORAM. In: AB'SÁBER, A. (org) Projeto FLORAM - uma plataforma. Secretaria do Meio Ambiente/ SP - equipe do IF-CPRN. Revista Estudos Avançados. IEA/ USP: São Paulo. Maio/ agosto. Vol.4. Número 9.

SERRANO, J. S. (coord.) (1993) Catalogo ibero-americano de tecnicas constructivas industrializadas para vivienda de interes social. CYTED Proyecto XIV 2. Catalogo ibero-americano. Montevideo.

SHIMBO, L. Z. (2003) “A casa é o pivô": questões, conflitos e potencialidades do diálogo entre arquitetos e moradores em projetos de habitação. Estudo de caso: Assentamento rural "Fazenda Pirituba" (Itapeva/ SP). São Carlos: Programa de pós-graduação em arquitetura e urbanismo - EESC/ USP. [memorial de qualificação].

SHIMBO, L. Z. (2003) Práticas democráticas no projeto da habitação social como um dos aspectos da dimensão política da sustentabilidade: estudo de caso. In: ENCONTRO NACIONAL SOBRE EDIFICAÇÕES E COMUNIDADES SUSTENTÁVEIS, 3. Anais.... São Carlos: USP/ UFSCar/ UNESP.

SHIMBO, L. Z.; INO, A. (2004) Questões, conflitos e potencialidades do diálogo entre moradores e arquitetos sobre materiais construtivos sustentáveis para habitação. In: ENCONTRO NACIONAL DE TECNOLOGIA DO AMBIENTE CONSTRUÍDO, 10. São Paulo. Anais.... São Paulo, ANTAC. [CD].

SILVA, M. R.; SHIMBO, I. (2004) Processos participativos na formulação de políticas públicas de habitação como condição para a sustentabilidade política. In: ENCONTRO NACIONAL DE TECNOLOGIA DO AMBIENTE CONSTRUÍDO, 10. São Paulo. Anais...São Paulo, ANTAC. [CD].

SILVA, R. D.; BASSO, A. (2001) Análise de desempenho de habitações de interesse social em madeira: estudo de caso. In: ENCONTRO LATINO AMERICANO SOBRE EDIFICAÇÕES E COMUNIDADES SUSTENTÁVEIS, 1. Canela. Anais...Porto Alegre: NORIE/ ANTAC. p.219-226. 
SILVA, S. R. M. e SHIMBO, I. (2001) Proposição básica para princípios de sustentabilidade. In: ENCONTRO LATINO AMERICANO SOBRE EDIFICAÇÕES E COMUNIDADES SUSTENTÁVEIS, 1. Canela. Anais...Porto Alegre: NORIE/ ANTAC. p.73-79.

SILVA, V. G. (2002) Green Building Challenge 2002: Report of the Brazilian Team. In: GREEN BUILDING CHALLENGE. Oslo: iiSBE. [CD]

SILVA, V. G. et al. (2002) Environmental assessment of buildings: towards an appropriate approach to the Brazilian environmental agenda. In: SUSTAINABLE BUILDING, 3. Oslo. Proceedings... Oslo, Ecobuild. [CD].

SILVA, V. G. et al. (2003) Avaliação do desempenho ambiental de edifícios: critérios de ponderação de impactos ambientais de edifícios. In: ENCONTRO NACIONAL SOBRE EDIFICAÇÕES E COMUNIDADES SUSTENTÁVEIS, 3. Anais.... São Carlos: USP/UFSCar/UNESP.

SKOPEK, J.; BRYAN, H. (2002) Harmonization of LEED and BREEAM Green Leaf. In: SUSTAINABLE BUILDING, 3. Oslo. Proceedings... Oslo, Ecobuild. [CD].

SKOPEK, J.; MARSHALL, S.; BRYAN, H. (2002) Green Globes - An interactive online environmental performance assessment tool. In: SUSTAINABLE BUILDING, 3. Oslo. Proceedings... Oslo, Ecobuild. [CD].

SPERB, M. R. (2000) Avaliação de tipologias habitacionais a partir da caracterização de impactos ambientais relacionados a materiais de construção. Porto Alegre. 130p. Dissertação de Mestrado - Universidade Federal do Rio Grande do Sul.

SPERB, M. R. e SATTTLER, M. A. (2001) Avaliação de tipologias habitacionais a partir da caracterização de impactos ambientais relacionados a materiais de construção. In: ENCONTRO LATINO AMERICANO SOBRE EDIFICAÇÕES E COMUNIDADES SUSTENTÁVEIS, 1. Canela. Anais...Porto Alegre: NORIE/ANTAC. p.165-172

STEER, A.; WADE-GERY, W. (1994) Environmental strategies for the developing world. In: In: Environmental strategies handbook: a guide to effective policies and practices. Kolluru, R. (editor). New York: McGraw-Hill. p 851-904.

STRAND, S. M. (2002) The MaSe-system: a material selection system for environmental conscious material selection. In: SUSTAINABLE BUILDING, 3. Oslo. Proceedings... Oslo, Ecobuild. [CD].

SUSTAINABLE DEVELOPMENT TASK FORCE (2003) Drivers for sustainable construction. FIDIC. Industry and environment, Paris, v.26, n. 2-3, p.22-25, abr-set. 
TAMBLYN, N. E. (1978) Preservation and preserved wood. In: Eucalypts for wood production. HILLIS, W. E; BROWN, A. G. Australia: CSIRO. p. 343-352.

THE HABITAT AGENDA (2003) The Habitat Agenda. Disponível em: $<$ http://www.unhabitat.org/declarations/habitat_agenda.htm> 109p. Acesso em: 12 set. 2004.

THE INTERORGANIZATIONAL COMMITTEE ON GUIDELINES AND PRINCIPLES FOR SOCIAL IMPACT ASSESSMENT (1994) Disponível em: <http://www.nmfs.noaa.gov/sfa/social_impact_guide.htm> Acesso em: 10 out. 2004.

TOMASELLI, I.; SCHEFFLER, L.F.; MEDEIROS, A.Z. (2004) Produtos florestais e as exportações. In: STCP Informativo. N 7 - 2003-2004. pg 10-13. Disponível em: <http://www.stcp.com.br> Acesso em: 13 abr.

TRUGILHO, P.F et al. (2002) Classificação de árvores de eucalipto de acordo com a qualidade das tábuas após a secagem natural. In: ENCONTRO BRASILEIRO EM MADEIRA E EM ESTRUTURAS DE MADEIRA, 8. Uberlândia. Anais...Uberlândia, UFU. [CD].

TRUSTY, W. B. (s.d.) Introducing an assessment tool classification system. Disponível em: http://www.athenasmi.ca/papers/down papers/Assess'TypologyTool.pdf. Acesso em: 10 out. de 2004.

UNEP (2001) Life cycles thinking as a solution. Disponível em: $<$ http://www.uneptie.org/pc/sustain/lcinitiative/background.htm>. Acesso em: 18 de dez. de 2003.

UNITED STATES GREEN BUILDING COUNCIL (USGBC). (2002) LEED ${ }^{\text {TM }}$ Green Building Rating System for new construction and major renovations (LEED NC) - Version 2.1. Disponível em: <http://www.usgbc.com> Acesso em 03 dez. 2003.

URURAHY, J.C.C. (2004) Brasil vive apagão florestal. Disponível em: <http://www.sbs.org.br/destaques_apagaoflorestal.htm> Acesso em: 24 abr.

VALARELLI, I.D.; GONÇALVES, M.T.T. (2002) Otimização do processo de usinagem em operações de desdobro. In: ENCONTRO BRASILEIRO EM MADEIRA E EM ESTRUTURAS DE MADEIRA, 8. Uberlândia. Anais...Uberlândia, UFU. [CD].

VIANA, J. C. (2003) Análise de durabilidade de habitações em madeira. Estudos de caso. São Carlos: USP. [Relatório parcial PIBIC CNPq - Agosto/2002 a janeiro/2003]. 
VOINSON, P.; CASTAGNÉ, M. (1988) La filiere bois batiment du sud Bresil. Nancy: Presses Universitaires de Nancy. 136p. [ Collection les Entretiens de Brabois].

WACKERNAGEL, M.; REES, W. (1997) Our ecological footprint; reducing human impact on the Earth. London: New Society. 160p.

WELLS, J. (2003) Social aspects of sustainable construction: a ILO perspective. Industry and environment, Paris, v.26, n. 2-3, p.72-75, abr-set.

WILSON, A. (1997) Disposal; the Achilles' heel of CCA - treated wood. ? Environmental Building News, Brattleboro, mar. Disponível em:

$<$ http://www.buildinggreen.com/features/tw/treated_wood.htm> Acesso em: 17 out. 2000 .

WILSON, A. (2000) Building materials: what makes a product green? Environmental Building News, Brattleboro, jan. Disponível em:

<http://www.Buildinggreen.com/features/gp/green_products.htm> Acesso em: 03 out. 2000 .

YLI-KARJANMAA, S. (2000) Social cost-benefit analysis. Disponível em: $<$ http://www.research.scpm.salford.ac.uk/bqtoolkit/index2.htm> Acesso em: 07 set. 2004.

YONENAGA, W. H. (2001) Utilização de system dynamics no gerenciamento de florestas. São Carlos: UFSCar. Dissertação de Mestrado. Programa de pós-graduação em engenharia de produção. 82 p.

YUBA, A. N. Cadeia produtiva de madeira serrada de eucalipto para produção sustentável de habitações. Porto Alegre. 156p. Dissertação de mestrado em Engenharia Civil - PPGEC, Universidade Federal do Rio Grande do Sul.

YUBA, A. N., SATTTLER, M. A., BONIN, L. C. (2001) Uso da madeira de reflorestamento como material de construção e os desafios para o desenvolvimento sustentável. In: ENCONTRO NACIONAL SOBRE EDIFICAÇÕES E COMUNIDADES SUSTENTÁVEIS, 2 e ENCONTRO LATINO AMERICANO SOBRE EDIFICAÇÕES E COMUNIDADES SUSTENTÁVEIS, 1 . Anais.... Porto Alegre: ANTAC.

YUBA, A.N.; LIMA, G.L.; TAMAI, M.T.; SHIMBO, I. (2000) Caracterização dos resíduos de madeira do Município de Santo André. In: ENCONTRO NACIONAL DE TECNOLOGIA DO AMBIENTE CONSTRUÍDO, 8. Salvador. Anais...Salvador, UFBA. [CD]. 
ANEXO - Declarậ̃a ambiental 


\section{ENVIRONMENTAL DECLARATION \\ THE NORDICTIMBER INDUSTRY \\ NR 9604027E TRÄTEK - SWEDISH INSTITUTE FOR \\ WOOD TECHNOLOGY RESEARCH}

\section{THE COMPANY}

\section{Manufacturer}

Number of sawmills: 15

Location: North to South in Sweden.

Additional information:

The Environmental Declaration is based on data from 1994. A contact person is identified ateach sawmill, (seenextpage).

\section{Environmental activities}

- The sawmills are subject to the granting of permits in accordance with the Environmental Protection Act and submit annual reports to the authority concerned.

- Some of the sawmills have an environmental policy and environmental programmes in accordance with an Environmental Management System.

-Some of the sawmills are certified in accordance with quality system ISO 9002 .

\section{THE PRODUCT}

Sawn timber of pine and spruce.

The raw material comes from local regional harvesting areas in the vicinity of the sawmill.

Felling is carried out in accordance with the Silvicultural Act and is controlled by the County Forestry Board.

Systems for environmental certification of the forestry are under discussion but are not yet in force.

Product content, $\mathrm{kg}^{*} / \mathrm{m}^{3}$

softwood timber, untreated 460

"Oven dry density (excluding water)

\section{Packaging}

A timber package utilises wood battens , wrapping of $\mathrm{PE}^{*}$ or cardboard or a combination, bound with steel bands. A lot of timber packages are also without wrapping materials on request of the customers. "PE = polythene foil

\section{Transport}

Sawlogs are transported by lorry from the forest to the sawmills and the average distance is about $55 \mathrm{~km}$. Internal transport is by forklift trucks and conveyor belts. Depending on the final destination a combination of road, rail and sea transport are used.

\section{MANUFACTURE}

Emissions into water/the ground

Water sprinkling of timber is carried out in the summer only. Timber stocks are being reduced more and more, and climatecontrolled water sprinkling system has been introduced. This leads to a lower environmental impact. Emission to the ground is mainly caused by waste bark and ashes which are often deposited in dedicated areas. Waste bark is used more and more and converted into energy or products such as fertilizers or fill for roads. The sawmills are also trying to return ashes to the forest and thus complete the ecological cycle.

\section{Emission into the air}

Furnaces give off particulate matter and flue gases. Carbon dioxide from the burning of bio fuels are part of the natural forest cycle and do not contribute to the greenhouse effect. Carbon dioxide from the burning of oil and diesel oil is shown in the environmental profile (next page). Exhaust gases are emitted from vehicles. The wood-working processes causes an emission of wood fibres and terpenes,i.e. the scent of wood. Growing forests and bark storage etc. also emit terpenes.

\section{Noise}

Noise is caused by vehicles and by conveyors, sawdust collectors and fans during the process. Noise reduction measures have been introduced in most sawmills.

\section{Energy}

Sawn timber is produced in modern sawmills with various types of sawing lines (frame, circular and band sawing). Mainly bio fuel and electricity are used.Timber waste from the process is converted into energy. Very little oil is used - on an average approx. $20 \mathrm{MJ} / \mathrm{m}^{3}$ sawn timber. The timber is dried to at least $18-20 \%$ moisture content (u).Energy consumption is strongly dependent on the moisture content to which the timber is to be dried. Production of sawn timber $(\mathrm{u}=18 \%)$ uses approx. $1360 \mathrm{MJ} / \mathrm{m}^{3}\left(380 \mathrm{kWh} / \mathrm{m}^{3}\right)$.

\section{Life-cycle of timber products}

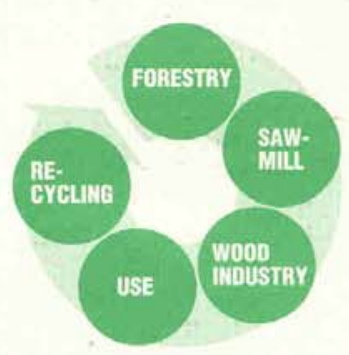

Renewable material in the product, $100 \%$ weight

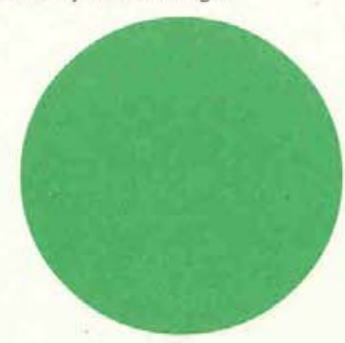

Energy use (\%) to manufacture $1 \mathrm{~m}^{3}$ sawn timber

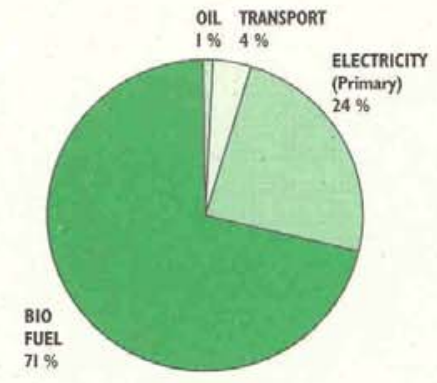

Emissions into the ground - manufacture

$\mathrm{kg} / \mathrm{m}^{3}$ of sawn timber

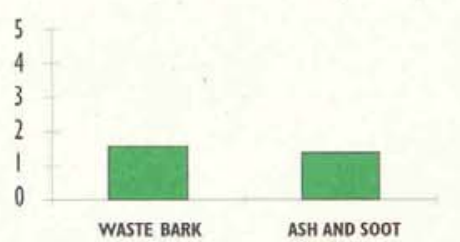

\section{Trätek}




\section{USE}

Sawn timber is a product which is $100 \%$ based on renewable raw materials from a natural ecological cycle.

Sawn timber is used for both simple consumer articles and large technically advanced structures such as bridges and multi-storey housing.

Sawn timber must be protected from damp during transport, on the building site and in structures.

Sawn timber is a material which has a long tradition of indoor use. As is well known, dry and clean wood is not subject to restrictions as far as the indoor environment is concerned (1)

\section{RECYCLING}

Reuse

Sawn timber is a flexible material which can simply and efficiently be reused for new products. Sawn timber can be cut, chipped etc and in principle be $100 \%$ recycled. (Timber which has been coated may require special attention.)

\section{Energy recovery}

Sawn timber can be fully converted completely into energy. This can be done locally in small furnaces or regionally in large combined power/heat plants.

Disposal

Timber is a biological material which in time is naturally broken down by microorganisms occuring in a balanced ecological system.

\section{ENVIRONMENTAL \\ PROFILE}

Sector data (average, 1994) from 15

sawmills in Sweden.

Sawn timber, $\mathrm{m}^{3}$ with a moisture content of about $18 \%$.

\section{Emissions into the air, $\mathrm{g} / \mathrm{m}^{3}$}

\section{Particulate matter}

Carbon dioxide

Carbon monoxide

Hydrocarbons

Nitrogen oxides

Sulphur dioxide

\section{Emissions into water,}

(Suspended solids) ${ }^{11}$

(BOD) $)^{1)}$

$(\mathrm{COD})^{1)}$

\begin{tabular}{lr}
\hline Emissions into the ground, $\mathbf{g} / \mathbf{m}^{\mathbf{3}}$ & \\
\hline Ash & \\
2) & 1360 \\
Waste for controlled treatment & 30
\end{tabular}

Industrial waste ${ }^{3)}$

Waste bark, incl. stones

and gravel

Oil spills (vehicles)

Metals ${ }^{4)}$

\begin{tabular}{lr}
\hline Resource use: energy, $\mathbf{M J} / \mathbf{m}^{3}$ & \\
\hline Oil & 35 \\
Biofuel & 150 \\
Primary electricity/Swedish mix $\left.^{5}\right)$ & 385 \\
Diesel (transportation) & 220 \\
Total: & $\mathbf{1 7 9 0}$
\end{tabular}

\begin{tabular}{ll}
\hline $\begin{array}{l}\text { Resource use: auxiliary materials, } \\
\mathbf{k g} / \mathbf{m}^{3}\end{array}$ \\
\hline Packaging materials: & \\
Wood battens & 2.1 \\
Steel bands & 0.3 \\
Wrapping & 0.4 \\
Process oils: & 0.1 \\
& \\
\hline Resource extension, $\mathbf{s o l i d ~ \mathbf { ~ } ^ { 3 } / \mathbf { m } ^ { 3 }}$ \\
\hline Timber (roundwood) & 1.2
\end{tabular}

1) Local environmental impact at each sawmill. No average can be given. The discharge of sprinkling water used for timber is about $0,9 \mathrm{~m}^{3} / \mathrm{m}^{3}$.

2) Including unburnt material and gravel.

3) Specific data not available.

4) Is sorted and recycled.

5) Efficiency factor 0.54 .

Comments on the

environmental profile

The environmental profile covers forestry, production of sawn timber at sawmills and transport between forest and sawmills and within the sawmills (2), (3).

\section{ADDITIONAL INFORMATION}

Fiskarhedens Trävaru $\mathrm{AB}$ Gällö Kilafors Trä AB

Gällö Såg, Kilafors Trävaru

Hissmofors Såg AB

Kastets Sågverk, Korsnäs AB

Kopparfors Sågverk,

STORA Timber AB

Lövholmens Trä AB, AssiDomän

Moelven Dalaträ $\mathrm{AB}$

$\mathrm{AB}$ Möckelns Sågverk

Nyby Sågverk, Mälarskog Industrier $\mathrm{AB}$

$C$ A Olausson \& Söner AB

Östavallsågen, $\mathrm{SAEF} \mathrm{AB}$

Siljans Sågverk $\mathrm{AB}$

Skinnskatteberg Trä AB, AssiDomän

Åtvidabergs Trävaru $\mathrm{AB}$

References:

(1) 'Evaluation of health effects of volatile organic compounds from timber and timber products', Report P 9510035 (in Swedish), Trätek, 1995.

(2) Environmental declarations for wood products, Nordic Industrial Foundation, (in Swedish) Trätek 1996.

(3) Berg, S. 'Emissions to the atmosphere from fossile fuels in Swedish forestry - a stocktaking for LCA of timber products', Report P 9601004 (in Swedish), Trätek, 1996.

The design of and work methodology for environmental declarations for wood products have been drawn up in a Nordic R \& D project with representatives from the Danish Technological Institute (DTI), the Norwegian Institute of Wood Technology (NTI), Trätek (the Swedish Institute for Wood Technology Research) and the Technical Research Centre of Finland (VTT). Funds for R \& D have been received from NUTEK (the Swedish National Board for Industrial and Technical Development) and the Nordic Industrial Foundation.

This environmental declaration was compiled on 2 April 1996 by Britt-Inger Andersson,Trätek tel: +46 8-762 1800 . 